\title{
Fifteenth and Sixteenth-Century Northern European Prints at the Museum of New Zealand Te Papa Tongarewa
}

\author{
Annika Sippel
}

A thesis submitted in fulfilment of the requirements for the degree of Master of Arts in Art History 


\section{Contents}

Abstract

Acknowledgments

Introduction 1

Chapter 1: Collecting Fifteenth- and Sixteenth-Century 4

Northern European Prints

The Sixteenth Century $\quad 4$

The Seventeenth and Eighteenth Centuries $\quad 11$

The Nineteenth and Twentieth Centuries 20

$\begin{array}{lr}\text { Chapter 2: The Collectors } & 27\end{array}$

$\begin{array}{ll}\text { Bishop Monrad (1811-1887) and his Collection } & 27\end{array}$

Sir John Ilott (1884-1973) and his Collection 38

$\begin{array}{ll}\text { Te Papa and other Collectors } & 47\end{array}$

Chapter 3: The Prints $\quad 56$

The Artists and The Works: Artistic Development 60

$\begin{array}{ll}\text { Quality and Condition } & 80\end{array}$

$\begin{array}{ll}\text { Conclusion } & 92\end{array}$

$\begin{array}{ll}\text { Illustrations } & 96\end{array}$

$\begin{array}{ll}\text { Bibliography } & 126\end{array}$

$\begin{array}{ll}\text { Unpublished Sources } & 126\end{array}$

$\begin{array}{ll}\text { Books } & 128\end{array}$

$\begin{array}{ll}\text { Articles } & 134\end{array}$

$\begin{array}{ll}\text { Theses } & 138\end{array}$

Appendix: Catalogue of Fifteenth and Sixteenth-Century 139

Northern European Prints at Te Papa 


\section{Abstract}

This thesis examines the collection of fifteenth- and sixteenth-century German, Dutch and Flemish prints at the Museum of New Zealand Te Papa Tongarewa. Beginning with the donation of Bishop Monrad in 1869, prints from the Northern European schools have been added to the collection either through the generosity of private collectors or the museum's direct purchases which continue to the present day. The lives and collecting practices of these collectors are considered, as well as the artists and prints represented in the collection.

An analysis of the history of collecting prints from the Northern European schools demonstrates that their recognition as individual works of art was a rather slow process, whereas a canon of the great printmakers was established almost immediately. The place of Northern printmakers in this canon will be considered, as well as the changing ideas about prints and print collecting from the sixteenth to the twentieth centuries. The most significant collectors for Te Papa’s print collection were Bishop Monrad and Sir John Ilott, who together donated more than half of the 164 prints analysed here.

While the collecting practices of Monrad and Ilott have been studied individually before, it is worthwhile comparing them and considering their reasons for buying fifteenth- and sixteenth-century Northern European prints in particular. They emerge as collectors with similar financial means, who both made use of agents and had direct contact with dealers. Other private individuals have also emerged as print collectors, who made significant contributions to the collection, yet they have remained mostly unknown until now. In addition to this, Te Papa still has an active policy of purchasing more prints for the collection.

Finally the prints themselves are examined in detail, considering both their physical qualities and art historical significance, in order to highlight the strengths of the collection. Some prints from the collection will be analysed for the first time here, as no extensive research has previously been conducted on this particular part of Te Papa's print collection, and some of the prints were added very recently and have thus not been available for viewing until now. 


\section{Acknowledgments}

First and foremost I wish to thank my supervisor, David Maskill, for all the support and guidance he has given me throughout the course of this research. His encouragement and passionate approach to the subject are truly inspirational.

I would further like to thank Tony Mackle, Collection Manager of Prints and Drawings at the Museum of New Zealand Te Papa Tongarewa, for his patience, advice and expert knowledge. I am also grateful to Victoria Robson, Curator European Art, Te Papa, and Jennifer Twist, Archivist, Te Papa, as well as the staff of the Te Aka Matua Library at Te Papa, the Alexander Turnbull Library and Archives New Zealand for all of their assistance.

Finally, I would like to thank my friends, for constantly encouraging me throughout the last year, and especially my family, without whose support this thesis would not have been completed. Ich danke euch allen aus tiefstem Herzen. 


\section{Introduction}

The Museum of New Zealand Te Papa Tongarewa has significant holdings of both New Zealand and International prints in its collection. The earliest group of works in this collection comes from the fifteenth and sixteenth centuries, and includes prints by such artists as Martin Schongauer, Albrecht Dürer and Lucas van Leyden. Due to the delicate nature of prints, these works cannot be part of the museum's permanent exhibition display. Therefore, Te Papa makes an effort to display this valuable part of its collections by holding temporary exhibitions of prints in the Ilott Room on Level 4 in the museum, such as European Master Prints: The founding gift of Bishop Monrad, which opened on 22 September 2011 (until 4 March 2012). It displayed prints by eminent artists such as Dürer and Rembrandt, among other prominent names, which were donated by Bishop Monrad in 1869. The exhibition highlighted the significance of this group of prints by stating that 'This important collection of European fine prints is the founding art collection of Te Papa. It is also distinguished by being the earliest European print collection to be donated to a public institution outside Europe.'1 Monrad's collection, however, makes up only a part of the 164 Northern European prints at Te Papa. A selection of another 26 works was also touring the South Island last year; the exhibition was entitled Albrecht Dürer and 16th century German printmaking (26 June 2010 - 20 March 2011).

Just like that exhibition, this investigation will focus on the Northern printmakers from the fifteenth and sixteenth centuries, which make up only a small portion of Te Papa's print holdings. The reasons for and the way in which they have been collected by their original owners will be the focus of this research, as well as the manner in which they came to Te Papa's collection, and their physical attributes. The strengths of the collection will be highlighted, and individual prints that contributed to the artistic development of the medium will be examined.

The first chapter will look at the manner in which Northern European prints from the fifteenth and sixteenth centuries have been perceived and collected from the sixteenth

\footnotetext{
1 'European Master Prints: The founding gift of Bishop Monrad', http://www.tepapa.govt.nz/WhatsOn/ exhibitions/Pages/EuropeanMasterPrintsthefoundinggiftofBishopMonrad.aspx.
} 
century until today. This will involve establishing when prints were first acknowledged as independent works of art and collectors' items, as well as when a canon of Northern European printmakers was first formed. Did Northern prints always enjoy a preeminent place in print collections or has this canon altered over the centuries? The increasing importance placed on prints can also be determined by looking at the manner in which collectors have arranged their prints within their collections. Towards this end the collecting practices of some individual collectors and a sample of the literature available on the subject from throughout the centuries will be analysed. ${ }^{2}$ While there is a large amount of modern literature on the subject of print collecting available today, most of this focuses on collecting activities during a specific time span; an attempt will be made here to look succinctly at the entire history of collecting Northern prints.

Chapter Two will deal specifically with the collecting practices of the collectors whose donations make up Te Papa's collection of Northern European fifteenth- and sixteenth-century prints. The most generous gifts were made by Bishop Monrad (18111887) and Sir John Ilott (1884-1973), who were collecting in nineteenth-century Denmark and twentieth-century New Zealand respectively. Seeing that Monrad only spent three years in New Zealand, while Ilott was born and raised here, the personal reasons for their substantial gifts will be examined. Their motivations for collecting prints in the first place (particularly Northern Renaissance ones) and their manner of acquisition and storage and display will also be compared to one another, in order to determine whether these decisions were affected by the time and place in which they lived. A special mention of the other collectors who contributed to Te Papa's holdings of German and Flemish fifteenth- and sixteenth-century prints will also be made, as these collectors have remained mostly unknown. Even if they often only donated a single print, their contributions should be appropriately recognised and valued.

While these collectors might have had different reasons for collecting and donating Northern Renaissance prints to the nation, together with Te Papa's recent purchases their efforts have created a national collection which showcases a wide range of Northern printmakers. Chapter Three will examine in detail these artists and their prints in the collection, in order to determine whether they illustrate the development of the print medium in the North from the end of the fifteenth century until the end of the

\footnotetext{
${ }^{2}$ Texts have been analysed in their original language; all translations from German, Italian, French and Danish are the author's unless otherwise stated.
} 
sixteenth. This period witnessed the rise of numerous prominent printmakers, such as Albrecht Dürer, Lucas van Leyden and Hendrick Goltzius, who among others helped to cultivate various print media (including woodcut, engraving and etching), created new subjects for printmaking and introduced Italian Renaissance forms into Northern art.

After having considered the contents of Te Papa's collection, the quality and physical condition of the prints will also be examined. Theodore B. Donson wrote that 'The primary source of information about a print is the print itself. Although good facsimiles and illustrations may exist, to know a print one must really see it. ${ }^{3}$ Thus, the prints in the collection have been closely examined individually for this research. A sample of these 165 prints will be presented in this chapter, considering such factors as inking, scratches, watermarks and collector's marks, rips, folds and margins. These aspects will aid in determining whether an impression is early or late, fine or poor, and how the print has been handled and stored since its production, enabling an overall assessment of the quality of Te Papa's collection of Northern European fifteenth- and sixteenth-century prints.

\footnotetext{
3 Theodore B. Donson, Prints and the print market: a handbook for buyers, collectors, and connoisseurs, New York: Thomas Y. Crowell, 1977, p. 386.
} 


\section{Chapter One: Collecting Fifteenth- and Sixteenth- Century Northern European Prints}

Before starting to look at the individual collectors who have contributed to Te Papa's holdings of Northern Renaissance prints, it is advisable to consider the history of collecting such items, in order to place their activities within a broader context. Just as works of art have a history that develops over time, so too does the activity of collecting them. In order to trace the history of print collecting, one must establish the moment when prints were first appreciated as collector's items and study the reasons why and the manner in which they have been collected. Seeing that this research is concerned with Northern European prints of the fifteenth and sixteenth centuries, their role within a canon of master printmakers will also be analysed, so that we might determine the esteem in which they have been held by collectors throughout the centuries.

\section{The Sixteenth Century}

[I have discussed engravers and their art] in order to satisfy not only the students of our arts, but also all those who delight in works of that kind. ${ }^{1}$

The first collectors of Northern Renaissance prints were in fact artists themselves, most of whom were painters. They collected them within their workshops, stuck them on the wall for the purpose of studying them and thus improving their own art. Francis Ames-Lewis explains that 'two-dimensional models were vital both in training and in the regular practice of the painter's workshop. One of the most significant developments for these bottega processes was the introduction of the printed image'. ${ }^{2}$ So we have the young Michelangelo copying Martin Schongauer’s Temptation of St Anthony, c. 147075, as an apprentice in Ghirlandaio’s workshop, resulting in his first known painting, The Torment of Saint Anthony, c. 1487-88 (Fort Worth: Kimbell Art Museum). However, prints were not always copied in their entirety like this, but artists often chose particular aspects of an engraving to include in their own work. Marcantonio Raimondi, for example, used the landscape background of Lucas van Leyden's Mohammed and the

\footnotetext{
${ }^{1}$ Giorgio Vasari, Le vite dei più eccellenti pittori, scultori e architetti, Rome: Newton Compton editori, 2010 [1568], p. 854, 'per sodisfare non solo agli studiosi delle nostre arti, ma tutti coloro ancora che di cosi fatte opera si dilettanto.'

${ }^{2}$ Francis Ames-Lewis, The intellectual life of the early Renaissance artist, New Haven and London: Yale University Press, 2000, p. 39.
} 
monk Sergius, 1508, in his engraving after Michelangelo Bathing soldiers, 1510, acknowledging the Northern mastery of landscape depictions. ${ }^{3}$

The most obvious example of such a 'model-engraving' is Antonio del Pollaiuolo's Battle of the Nudes, c. 1470 (London: British Museum), the primary purpose of which, according to Ames-Lewis, was to demonstrate the artist's skill in figure-drawing, as well as provide other artists and apprentices with exemplars of the male nude in various poses and angles. ${ }^{4}$ Pollaiuolo’s use of a reversal system, which allowed him to show a figure's anatomy and pose from the front and the back, proved especially educational and influential, as it enabled artists to study a complete figure in the round, as if it were a three-dimensional model. Albrecht Dürer adopted this method in his drawing of the Abduction of the Sabine Women, 1495 (Bayonne: Musée Bonnat), which demonstrates the exchange of ideas between Italy and the North; Italian artists studying German prints, and German artists using Italian ones. Peter Parshall explains that stocks of prints accumulated in workshops would normally be passed from generation to generation, either through family ties, or from master to pupil. ${ }^{5}$ But, in view of the increasing demand for artistic innovation and contemporary styles, 'out-dated' prints from earlier periods did not have a long future in a workshop bound to the ever-changing currents of taste and trend. ${ }^{6}$

Thus a new breed of non-artist collectors had to emerge at this time, which would account for the survival of such an extensive number of Renaissance prints until the present day. The earliest types of these collectors, though, did not separate prints from other items in their collections and often kept them as part of their library. Therefore they did not entirely recognise them as individual works of art, but rather as decorative embellishment, a practice reflected in the common fifteenth-century tendency of pasting devotional images into prayer-books. ${ }^{7}$ An example of such an early print collector was the Nuremberg medical doctor and humanist Hartmann Schedel (1440-1514), who had acquired several hundreds of prints during his lifetime, only to use them to illustrate his

\footnotetext{
${ }^{3}$ Bart Cornelis and Jan Piet Filedt Kok, 'The taste for Lucas van Leyden prints', Simiolus: Netherlands Quarterly for the History of Art, 26 (1/2), 1998, p. 20.

${ }^{4}$ Ames-Lewis, p. 42.

${ }^{5}$ Peter Parshall, 'Art and the theatre of knowledge: the origins of print collecting in Northern Europe', Harvard University Art Museums Bulletin, 2 (3), 1994, p. 10.

${ }^{6}$ ibid.

${ }^{7}$ Peter Parshall, 'The Print Collection of Ferdinand, Archduke of Tyrol', in Jahrbuch der Kunsthistorischen Sammlungen in Wien, Volume 78, Vienna: Anton Schroll and Co., 1982, p. 140.
} 
books. Loose sheets were pasted at the front and back of his codices, or inserted into blank pages in the body of the text, often badly hand-coloured by the collector himself. ${ }^{8}$ Unlike the library itself, the acquisition and arrangement of Schedel's prints did not appear to have a clear system, and the noticeable lack of works by artists like Dürer and Schongauer suggests that he was not guided by the standards of artistic quality and reputation. ${ }^{9}$

Before looking at examples of sixteenth-century collectors who devoted a separate space for prints in their collections, however, one should first analyse the literature of the time in order to understand the significance prints held for people other than artists, thus providing an insight into their motivations for collecting. One of the most authoritative voices of the sixteenth century was undoubtedly Giorgio Vasari, who becomes significant for studying the history of print collecting as he provided the first written account on the art of engraving by giving it a historical context (tracing its origins and development). The second edition of his Lives of the most excellent Italian painters, sculptors, and architects (1568) includes the life of Marcantonio Raimondi and other engravers, incorporating the life and work of Northern artists such as Martin Schongauer, Albrecht Dürer and Lucas van Leyden. While he certainly admired their skill with the burin, his national pride would not allow him to value their achievements higher than those of his countrymen. Throughout the Lives he criticises the Northern schools for the hardness of their style and their lack in design, claiming that they can never equal the superior art of the Italians, which is based on the study of antiquity. Marcantonio’s engravings, for example, ‘were held in much higher estimation, on account of their good design, than those of the Flemings' ${ }^{10}$

Northerners were not the only printmakers under attack, however. In fact, Vasari does not appear to have valued printmaking as a medium in itself very highly. He makes repeated references to the fact that printmaking is inferior to painting and merely reproductive in function, characterising it as a craft, rather than an art. Talking about Schongauer’s and Dürer’s works, Vasari claims that ‘their works are commended only for the diligent execution of the engraving', thus only admiring their technical skill in

\footnotetext{
${ }^{8}$ David Landau and Peter Parshall, The Renaissance print: ca. 1470-1550, New Haven: Yale University Press, 1993, p. 64.

${ }^{9}$ ibid, pp. 64-65.

${ }^{10}$ Vasari, p. 843, 'erano molto più stimate le cose sue, pel buon disegno, che le fiaminghe'.
} 
execution. ${ }^{11}$ He praises Lucas van Leyden's use of aerial perspective, because it creates a pictorial effect as in painting: 'indeed, he executed them with such thoughtful care, and made them so soft and well blended, that they would not be better in colour; and his judicious methods have opened the eyes of many painters. ${ }^{12}$ Vasari spends a great deal of time discussing Marcantonio’s prints made after the designs of Raphael and concludes that, generally speaking, printmakers

have none the less benefited the world with their labours, by bringing many scenes and other works of excellent masters into the light of day, and by thus giving the means of seeing the various inventions and manners of the painters to those who are not able to go to the places where the principal works are. $^{13}$

As David Landau and Peter Parshall have observed, the value of prints was no longer to be found in the quality of their own invention, composition, or command of tonality, but rather in their ability to convey these characteristics as they found them in the original works which they copied. ${ }^{14}$

While the lack of information or even of names in some cases, demonstrates the low regard Vasari had for Northern printmakers, the space and placement he gives to the medium itself within the preface and other parts of the text is further revealing about his attitudes. In the preface Vasari lists all the branches of painting, beginning with tempera, fresco, oil on wood, stone or canvas, illumination and glass-painting, mosaic, intarsia of coloured woods, graffito decoration of house-facades and, eventually, nielli and prints. This position of prints is in itself revealing of their standing in his mind. ${ }^{15}$ In the general chapter Della Pittura, dealing with techniques, prints have moved to the very end of the list; also the section on engraving only takes up five lines (as opposed to several pages, for instance, devoted to glass painting). ${ }^{16}$ A further indication that Vasari did not think highly of printmaking can be gathered from the fact that he himself, an avid collector, did not appear to own many prints at all. At the end of the life of

\footnotetext{
${ }^{11}$ Vasari, p. 839, 'le cose loro sono per la diligenza solo dell’intaglio, l’opere loro comendate.'

12 ibid, p. 843, 'però le fece con queste considerazzioni, e sfumate e tanto dolci, che col colore non si farebbe altrimenti; le quali avertenze hanno aperto gl'occhi a molti pittori.'

${ }^{13}$ ibid, p. 850, 'hanno nondimeno con le loro fatiche giovato al mondo e mandato in luce molte storie et opera di maestri eccellenti, e dato commodità di vedere le diverse invenzioni e maniere de' pittori a coloro che non possono andare in que' luoghi dove sono l'opere principali'.

${ }^{14}$ Landau and Parshall, p. 362.

${ }^{15}$ David Landau, 'Vasari, Prints and Prejudice’, Oxford Art Journal, 6 (1), 1983, p. 3.

${ }^{16}$ ibid.
} 
Domenico Beccafumi he talks about his activity as a printmaker and praises his two prints of Apostles: 'there are to be seen prints of two Apostles engraved by him excellently well, of which we have one in our book of drawings, together with some sheets drawn divinely by his hand. ${ }^{, 17}$ This is the only time Vasari admitted to owning a print himself, which he kept with his drawings. ${ }^{18}$

In view of this, one might wonder why Vasari bothered to include a chapter on engravers in the first place. One reason might have been the need for completeness; in the second edition of the Lives he was aiming to include that which had been lacking and for which he had been criticised in the first edition. He also certainly acknowledged the advantages of the reproductive nature of the medium, as his Lives are themselves illustrated with engraved portraits of the artists. At the end of the life of Marcantonio he also feels the need to justify his treatment of the subject, which he explains he did 'in order to satisfy not only the students of our arts, but also all those who delight in works of that kind. ${ }^{19}$ These others were most likely collectors, who were already avidly acquiring the prints of artists Vasari mentioned, such as Dürer, whose prints Vasari claims were already becoming rare in his own time. Despite his negative view of printmaking, the mere fact that Vasari wrote on the subject contributed highly to the advancement of the medium, not to mention the fact that he was among the first to actually provide collectors with a canon of the best printmakers. Despite the fact that they were not Italian, Vasari ranked Schongauer, Dürer, van Leyden and Lambert Suavius among the best engravers, along with Marcantonio, Marco Dente, Caraglio, Giovanbattista Mantovano and Vico. He even set up a canon of their best works, claiming that the large Ecce Homo, 1510 (Amsterdam: Rijksmuseum), for example, brought Lucas van Leyden the most fame. ${ }^{20}$

This emergence of a canon was in line with what earlier Italian writers had suggested, and it indicates that the sixteenth century had truly accepted printmaking as an art form in itself. ${ }^{21}$ In a letter from 1549 to Enea Vico, the merchant Agnolo Doni singled out Schongauer, Dürer, van Leyden, Marcantonio, Caraglio, Marco Dente and

\footnotetext{
${ }^{17}$ Vasari, p. 919, 'se ne veggiono fuori due Apostoli fatti eccellentemente, uno de' quali n’avemo nel nostro libro de' disegni, con alcune carte di sua mano, disegnate divinamente.'

${ }^{18}$ Landau, 'Vasari, Prints and Prejudice', p. 4.

${ }^{19}$ Vasari, p. 854, 'per sodisfare non solo algi studiosi delle nostre arti, ma tutti coloro ancora che di così fatte opera si dilettanto.'

20 ibid, p. 842.

${ }^{21}$ Michael Bury, ‘The taste for prints in Italy to c. 1600’, Print Quarterly, 2 (1), 1985, p. 24.
} 
Vico himself. ${ }^{22}$ Francisco de Holanda’s Da Pintura Antigua (1548) highlights Dürer, van Leyden, Marcantonio, Agostino Veneziano and Mantegna as among the best representatives of the medium. ${ }^{23}$ Hence a clear pattern emerges, with both Italian and Northern artists being acknowledged as master printmakers. While these authors certainly participated in the advancement of printmaking, none of them actually treated prints as collector's items in their written work. This keystone in the literature of print collecting was achieved by the Belgian medically trained librarian, in charge of the cabinet of curiosities of Albrecht V of Bavaria, Samuel van Quicchelberg.

Quicchelberg's Inscriptiones vel tituli theatri amplissimi (1565) is the earliest known guide for the assembly of a print collection by a collector rather than an artist. ${ }^{24}$ Essentially, what it described was an encyclopaedic museum, or universal theatre, such as the one accumulated by Albrecht $\mathrm{V}$, which represented every discipline and every form of human activity. ${ }^{25}$ Renaissance collectors aimed at creating a microcosm of the entire world by assembling a vast variety of objects, both man-made and natural, in order to promote universal knowledge. As William W. Robinson explains, this educational purpose overshadowed the aesthetic pleasure derived from art works, which were subsequently forced to share the limelight with natural and ethnographic rarities. ${ }^{26}$ Another result of this didactic pursuit of knowledge and information was the organisation of art works according to their subject matter, creating a visual encyclopaedia of the world. Thus Quicchelberg advised that in an ideal collection of prints should also be arranged upon three shelves under ten to eleven topics to each shelf. These thirty-two subject categories included saints, portraits, ancient history, modern customs, geography and ornamental designs, just to name a few. ${ }^{27}$

This approach is far from the art historical method used in museums today, which makes the artist and national school the primary factors for organisation. Still, Quicchelberg took the first step in this direction by fully acknowledging the artistic qualities of prints alongside their educational potential. As Elizabeth M. Hajós states,

\footnotetext{
22 Bury, p. 24.

${ }^{23}$ ibid.

${ }^{24}$ William W. Robinson, “"This Passion for Prints”: collecting and connoisseurship in Northern Europe during the seventeenth century', in Clifford S. Ackley (ed.), Printmaking in the Age of Rembrandt, Boston: Museum of Fine Arts, 1981, p. xxxi.

${ }^{25}$ Bury, p. 13.

${ }^{26}$ Robinson, p. xxxi.

${ }^{27}$ Hajós, Elizabeth M., 'The concept of an engravings collection in the year 1565: Quicchelberg, Inscriptiones vel Tituli Theatri Amplissimi’, The Art Bulletin, 40 (2), 1958, p. 153.
} 
his greatest achievement was 'that he recognized and declared engravings to be works of art. ${ }^{28}$ The print collection described by him was merely one of several subdivisions of one of five classes which structured the entire universal theatre. While prints are mentioned throughout the different classes, engravings are specifically allocated to the fifth class, devoted to 'Painting (in oils and water colors) and engraving, corresponding, in part, to an "art collection”, ${ }^{29}$ By assigning engravings to the same class as painting, he essentially placed the medium on an equal footing with painting and publically declared prints as works of art.

Therefore Quicchelberg categorised prints as art works, and by assigning them a separate place in a collection, he contributed to the emergence of the 'second phase' of Renaissance collecting. Still he organised them strictly by subject matter, a trend initiated by earlier collectors who pasted them into books, and followed by various collectors of the later sixteenth century. Archduke Ferdinand of Tyrol had a substantial collection of prints; the ones from the surviving albums alone amount to over 5,000 impressions. ${ }^{30}$ He did not store his prints with his library, but instead gave them a prominent place in the room of his Kunstkammer. As Quicchelberg had suggested, the prints were grouped into volumes under various topical titles, reflecting the 'presumed use of the collection as a reference source within the Kunstkammer scheme. ${ }^{31}$ There is no attempt made at creating a historical survey of artists and regional schools. Ferdinand Columbus' print collection is the earliest known example of this 'second phase' type of collection, formed as a separate entity in his library. ${ }^{32}$ It was again arranged according to the prints’ physical characteristics and contents, rather than authorship. Ferdinand devised a straightforward system with four criteria to organise his prints, the first two of which were size and subject matter. ${ }^{33}$ Nonetheless, the sixteenth century also saw the first attempts at collecting an individual artist's oeuvre.

Contrary to Quicchelberg's advice, Abraham Ortelius' collection of Dürer prints is not organised as a system of learning, but rather he collected them simply because they

\footnotetext{
${ }^{28}$ Hajós, p. 154.

${ }^{29}$ ibid, p. 152.

${ }^{30}$ Parshall, 'The Print Collection of Ferdinand, Archduke of Tyrol', p. 145.

31 ibid.

${ }^{32}$ Mark P. McDonald, “”Extremely curious and important!”: reconstructing the print collection of Ferdinand Columbus', in Christopher Baker, Caroline Elam and Genevieve Warwick (eds.), Collecting Prints and Drawings in Europe, c. 1500-1750, Burlington: Ashgate, 2003, pp. 37-51, p. 40.

33 David Landau, 'The print collection of Ferdinand Columbus (1488-1539)', in Baker, Elam and Warwick, pp. 29-36, p. 30.
} 
were by Dürer and testified to his greatness, making his collection one of the first that assembled the whole work of an individual artist-engraver. ${ }^{34}$ Other collectors during the second half of the century also turned to systematic collecting of outstanding printmakers. Cardinal Scipione Gonzaga, collecting in Italy during the 1560s, arranged his prints in great books, two volumes of which were entirely devoted to Dürer, one to van Leyden and another one to Cornelius Cort. ${ }^{35}$ As Iain Buchanan observes:

The idea of collecting all the works of an individual artist marks the gradual rise in importance of the artist-engraver, and works of Lucas van Leyden and Dürer were particularly suitable for this purpose, as they were usually signed and dated, allowing a comprehensive collection to be assembled. ${ }^{36}$

Even in the encyclopaedic collection of Archduke Ferdinand there is one volume dedicated specifically to Dürer’s works: ‘A book, bound in black leather, containing subjects from the Old Testament by Albrecht Dürer. ${ }^{37}$ Although the time when an entire collection was just made up of prints alone, arranged according to artists and schools, was still to come, the stage had been set.

\section{The Seventeenth and Eighteenth Centuries}

The Art of Engraving was never more encouraged than in the present day, especially in England, where almost every man of taste is in some degree a collector of prints. ${ }^{38}$

The next two centuries witnessed not only a surge in the numbers of print collectors, but also in the amount of literature available on the medium. Writers and collectors of the seventeenth century continued many of the sixteenth-century practices and attitudes towards prints, though often slightly altered, culminating in a drastic change around the turn of the century. Giulio Mancini, the Sienese doctor and personal physician to Urban VIII from 1623, talks about a collection of prints in the section on display in his Considerazioni sulla Pittura (1617-1621). The Considerazioni were written for virtuosi or amateurs, providing them with information on the different areas of painting, its history, and criteria for judging quality. ${ }^{39}$ The section on display is essentially a

\footnotetext{
${ }^{34}$ Iain Buchanan, 'Dürer and Abraham Ortelius', The Burlington Magazine, 124 (957), 1982, p. 741.

${ }^{35}$ Bury, p. 16.

${ }^{36}$ Buchanan, p. 741.

371596 inventory of the Ambras Collection, quoted in Buchanan, p. 741, 'Ain buch, in schwarz leder eingebunden, von histori aus dem alten testament von Albrecht Türer.‘

${ }^{38}$ Joseph Strutt, A biographical dictionary: containing an historical account of all the engravers, from the earliest period of the art of engraving to the present time; and a short list of their most esteemed works, London: Robert Faulder, 1785, p. v.

${ }^{39}$ Baker, Elam and Warwick, p. 79.
} 
discussion on the arrangement of a painting collection, thus prints, though separated from a collector's library or encyclopaedic collection, are once again seen as part of another collection, namely of paintings. This type of collection was not only popular in Italy, visualised for example in the collection of Cardinal Francesco Maria del Monte, but the Flemish painting Cognoscenti in a Room hung with Pictures, 1620 (fig. 1) demonstrates similar combinations of paintings and prints displayed together in the North. While this might suggest that Mancini’s idea of a print collection was in fact based on aesthetic considerations, his system of arrangement reflected more the subjectbased scheme of Quicchelberg.

Mancini set up a classification system that mirrored a new trend in collecting which valued systematic organisation. Firstly, he writes that prints should be mounted in books or albums; secondly, they should be classified by subject, then by period, size, school and technique; thirdly, they should be kept in private rooms; and lastly, that the owner should be able to control how and by whom they are viewed. ${ }^{40}$ Yet, one might wonder why he gave such prominence to subject matter, if he was not actually advocating an encyclopaedic collection. Michael Bury suggests that one of the reasons was Mancini’s interest in different modi di fare (different ways of treating the same subject). ${ }^{41}$ Even when it came to the display of paintings he opposed single-artist groupings and, when religious paintings were to be arranged for example, he preferred different schools to be hung together, so that he could compare their different styles. ${ }^{42}$ Therefore, the early seventeenth century saw prints becoming significant not just for general encyclopaedic knowledge, but also for providing instructive devices for the viewing and appreciating of art itself. ${ }^{43}$

This comparative approach of Mancini was just one of the ways in which collectors could start to demonstrate their knowledge of art, making this one of the first steps towards the development of the modern-day print connoisseur. The next, and even more significant, step was taken by the etcher Abraham Bosse in his Sentimens sur la distinction des diverses manières de peinture, dessein et graveure, et des originaux d'avec leurs copies (1649). This was literally a handbook for connoisseurs of painting,

\footnotetext{
${ }^{40}$ Baker, Elam and Warwick, p.79.

41 ibid, p. 81.

${ }^{42}$ ibid.

43 Robinson, p. xxxvi.
} 
drawing and engraving, advising them on how to tell a copy from an original. ${ }^{44}$ The seventh chapter, entitled 'Sur la distinction des diverses manières des stampes ou taillesdouces, tant des originalles que des copies', deals exclusively with printmaking and the difference between prints by original masters and copyists. Bosse observes that copyists lacked the masters' inventiveness and that their lines appeared laboured and could not produce the delicate half-tones of the originals:

copyists are not as capable as the masters who are the designers of their own inventions, not even in their engravings after paintings or watercolours, where the hatched lines are consequently not expressed; thus their so-called copies appear hard, dry, and often more black than the originals ${ }^{45}$

Bosse goes on to talk about the quality of impressions, comparing the difference between early and later ones, and warning the collector about impressions made from re-engraved plates, which would turn out grey or whitish. ${ }^{46}$

Thus, seventeenth-century collectors started to value the quality and subsequently the rarity of prints, as owning such impressions would demonstrate their knowledge of connoisseurship. Bosse affirmed that serious collectors would insist on the earliest impressions, where the lines are printed very black, and the paper itself is very white. ${ }^{47}$ The Lucas van Leyden prints from the Amsterdam collector Michiel Hinloopen’s holdings are mainly late or damaged impressions, which suggests that good impressions

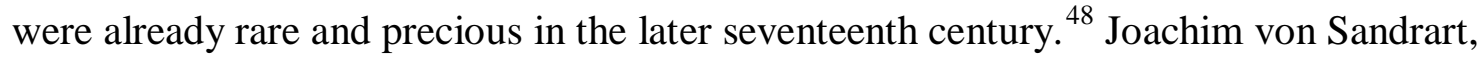
in his Teutsche Academie (1675-80), confirmed the collectors' craze for van Leyden's prints, claiming the Netherlandish art market was in a contest to acquire 'more and better' impressions from his hand. ${ }^{49}$ Sandrart also describes Lucas' print The beggars ('Owlglass'), 1520, which he wrote was in the possession of the Swedish ambassador Spiring and 'which I saw in no one else's collection'. ${ }^{50}$ In fact, The Owglass literally

\footnotetext{
${ }^{44}$ Robinson, p. xli.

${ }^{45}$ Abraham Bosse, Sentimens sur la distinction des diverses manières de peinture, dessein et graveure, et des originaux d'avec leurs copies, Paris: Chez l'auteur/published by the author, 1649, pp. 82-83, 'les copistes n’estans point capables de Desseigner d'Invention, ou du moins de Graver après des Tableaux ou Desseins lavez, où par conséquent les hachures ne sont pas exprimées, sont que leurs dites Copies paraissent dures, seiches, \& bien souvent plus noires que leurs Originaux’.

${ }^{46}$ ibid, p. 85.

${ }^{47}$ ibid.

${ }^{48}$ Cornelis and Kok, p. 50.

${ }^{49}$ Joachim von Sandrart, Teutsche Academie de Bau-, Bild- und Mahlerey-kunst von 1675: leben der beruhmten Maler, Bildhauer und Baumeister, Farnborough: Gregg, 1971 [1675-1680], p. 86.

${ }^{50}$ ibid, p. 86, 'das ich sonst bey niemand gesehen' .
} 
joined the formerly established canon of Lucas van Leyden's best works, based entirely on its rarity. ${ }^{51}$

The first English treatise to be considered here combined many of the concepts already discussed by other writers. John Evelyn’s Sculptura (1662) followed Vasari’s model of relating the origin and development of printmaking, yet unlike Vasari he undertook this task much more thoroughly, tracing its origins back to the first sculptor, Adam, and exploring its use in antiquity. In fact, Sculptura is the first truly comprehensive account of the history of a single medium. ${ }^{52}$ Evelyn further expanded on Bosse's ideas about differentiating between copies and originals, as well as discussing different states of impressions and the effects of re-engraved plates. ${ }^{53}$ In the spirit of Quicchelberg, he emphasised prints' educational role as sources of information that could be used to teach children: 'how capable this Art is, above all other whatsoever, to insinuate all sorts of notions and things into CHILDREN, and be made an instrument of education superior to all those abstracted terms'. ${ }^{54}$ As Peter Parshall explains, 'the encyclopaedic approach to collecting underwent a revival in the latter part of the seventeenth century when didactic and descriptive rationales for acquiring prints were stressed in the writings of both critics and patrons. ${ }^{55}$ Evelyn certainly advocated encyclopaedic motives for collecting, which would also account for the fact that his own print collection, pasted into books, was arranged by subject, including topography, portraits, costume, architecture and antiquities. ${ }^{56}$

It was Evelyn's section on the new print medium mezzotint, however, which reflected a significant change in collectors' tastes during the seventeenth century. Evelyn proudly claims to be the first person to publish on the new medium, which he wrote was invented by Prince Rupert of the Rhine. ${ }^{57}$ Sheila O’Connell explains that mezzotint was developed 'as a response to the seventeenth-century taste for striking contrasts of light and shade. The essentially linear techniques then available to

\footnotetext{
${ }^{51}$ Cornelis and Kok, p. 44.

52 Parshall, 'Art and the theatre of knowledge: the origins of print collecting in Northern Europe', p. 27.

53 John Evelyn, Sculptura: or, the history and art of chalcography, and engraving in copper, $2^{\text {nd }}$ edition, London: J. Payne, 1755 [1662], p. 114.

54 ibid, p. 120.

${ }^{55}$ Parshall, 'The Print Collection of Ferdinand, Archduke of Tyrol', p. 144.

${ }^{56}$ Antony Griffiths, 'John Evelyn and the Print', in Frances Harris and Michael Hunter (eds.), John Evelyn and his milieu, London: The British Library, 2003, p. 96.

${ }^{57}$ Evelyn, pp. 127-129.
} 
printmakers were not best suited to working in broad areas of tone. ${ }^{58}$ Evelyn certainly praises these qualities of mezzotint:

It would appear a paradox, to discourse to you of a graving, without a graver, burin, point, or aqua fortis, and yet is THIS performed without the assistance of either. [...] the lights should be in THIS the most laborious, and yet performed with the greatest facility; that what appears to be effected with so little curiosity, should yet so accurately resemble what is generally esteemed the very greatest. ${ }^{59}$

So it was once again the pictorial elements of prints that were praised. The Dutch painter Samuel van Hoogstraten (1627-1678), for example, admired Hercules Segers' efforts to introduce colour into his etchings, while Rembrandt was applauded for the pictorial effects in his etchings. ${ }^{60}$ Filippo Baldinucci, in his 1686 treatise on etching and engraving, wrote that Rembrandt's technique consisted of 'certain scribbles and little scratches and irregular, isolated strokes, the result of the whole, however, being a deep and powerful chiaroscuro, and a thoroughly pictorial sensibility’. ${ }^{61}$ Arnold Houbraken literally compared his work to mezzotints, writing that 'the tender, sparkling shadows [of Jan Cornelisz Sylvius, 1633] were ... as well and as delicately handled as mezzotint work. ${ }^{62}$ The new medium's qualities obviously set new standards against which printmakers had to be measured; qualities which old master prints did not always possess.

In a letter to Samuel Pepys, 26 September 1690, Evelyn wrote: 'And now of late the skilful in Mezzo-tinto masters, who, for imitation of life, sometimes excel the burin itself ever so accurately handled. ${ }^{, 63}$ That mezzotint could in fact surpass the art of line engraving, which until then had been the most prestigious form of printmaking, signalled a great change in taste and the formerly established canon of great printmakers. Hercules Segers, as well as the reproductive engravers Cornelis Bloemaert and Lucas Vorsterman were now thought of as part of an elite group of artists, and while Rembrandt himself was an avid collector of Lucas van Leyden prints, his work

\footnotetext{
${ }^{58}$ Sheila O’Connell, 'William Second Baron Cheylesmore (1843-1902) and the taste for Mezzotints', in Antony Griffiths (ed.), Landmarks in Print Collecting: Connoisseurs and Donors at the British Museum since 1753, London: British Museum Press, 1996, pp. 134-158, p. 134.

${ }^{59}$ Evelyn, pp. 127-128.

${ }^{60}$ Robinson, p. xlv.

${ }^{61}$ Quoted in Robinson, p. xlv.

62 ibid.

${ }^{63}$ John Evelyn and Samuel Pepys, Extracts from the diaries and correspondence of John Evelyn and Samuel Pepys relating to engraving, London: Ellis, 1915, p. 84.
} 
was starting to overshadow the efforts of the sixteenth-century artist and his contemporaries. The old Northern masters, especially artists such as Dürer and van Leyden, never lost their high-ranking status among the best printmakers; however, now they were in direct competition with contemporary artists, whose great advantage was that they could still adapt to current tastes.

Florent Le Comte’s Cabinet des Singularitez (1699) included an imaginary collection, entitled 'Idea of a Fine Library of Prints', which echoed Quicchelberg's (and Evelyn's) ideas about prints as tools of knowledge still at the turn of the century. Le Comte's collection consisted of a massive 151 albums divided into four sections: 'the First, to contain all Historical Subjects; the Second, all the Subjects of Morality; and the Third, every Thing that concerns the Progress of the Arts of Painting, Sculpture and Engraving; to which may be added a Fourth, containing mixed Subjects. ${ }^{64}$ The aim was clearly to extend the mind's reach over the entire universe of nature, history, morality and art, but unlike his predecessors, Le Comte believed that this could be achieved solely through collecting prints alone. During the second half of the century, print collections were finally separated from libraries and the Kunstkammer, and were given their own territory. As William W. Robinson explains 'Collectors and critics, aware that prints could furnish information about every conceivable subject, formulated the notion of a visual encyclopaedia composed exclusively of engravings, etchings, and woodcuts. ${ }^{65}$ One of the earliest collectors to privilege prints thus, and a direct inspiration for Le Comte's adoption of this idea, was also a significant participant in the discussion about how to best arrange prints.

This important contributor in the area of print organisation was the Frenchman Michel de Marolles, with his Catalogue de livres d'estampes et de figures en taille douce (1666). In the preface he claimed that if 'well selected and well ordered' prints will supply information about everything imaginable. ${ }^{66}$ The emphasis on well-selected prints indicates that he might have been familiar with Bosse's ideas about the importance of good quality impressions. It is the well-ordered arrangement of his collection, however, that illustrates his original notions. In the catalogue he described

\footnotetext{
${ }^{64}$ Florent Le Comte in Sculptura historico-technica: or, the history and art of engraving, extracted from Baldinucci, Florent le Comte, Fairthorne, the Abecedario pittorico, and other authors, $4^{\text {th }}$ edition, London: J. Marks, 1770 [1747], p. 110.

${ }^{65}$ Robinson, p. xxxv.

${ }^{66}$ Quoted in Robinson, p. xxxvi.
} 
his own print collection, ordered into two parts: 'arranged in good order, either according to the works of the Masters or to their different subject matter. ${ }^{67}$ Thus, while the second part of his collection continues Quicchelberg's and Evelyn's ideas about arranging prints according to subject matter, highlighting the educational benefits of prints as purveyors of knowledge, the first part is innovative for placing them under the names of masters (that is, the artists responsible for the design), focusing on the individual artist's talent. ${ }^{68}$ Also, while the second part appears to lack a specific system of classification, Marolles put more effort into arranging the prints in the first group according to the quality and popularity of masters, beginning with those 'whose works are esteemed above all others. ${ }^{69}$

This trend of organising prints according to artists actually began in the early part of the seventeenth century and can be exemplified by the collection of Johann Aegidius Ayrer (1598-1674). The collection, which had been passed down several generations of the Ayrer family in Nuremberg, did not belong to an encyclopaedic Kunstkammer, but rather showcased paintings, drawings, prints and a library. ${ }^{70}$ It featured albums devoted to outstanding German and Netherlandish printmakers; Johann Aegidius compiled his albums by artists, which Sandrart tells us consisted of twelve engravers, including Israel von Meckenem, Schongauer, Dürer, Lucas van Leyden and the 'Little Masters’ such as Barthel and Hans Sebald Beham, and Georg Pencz. ${ }^{71}$ More significant than the prominence placed on artists, though, was the fact that Johann Aegidius shelved his albums not according to the artist's popularity as Marolles did, but chronologically. ${ }^{72}$ This implies that he envisioned his collection as a survey of the origins and development of Northern Renaissance engraving, which makes it one of the earliest examples of the use of prints to demonstrate a history of art. ${ }^{73}$

This historical approach to print collecting acknowledged printmaking as an independent art form and was fully appropriated during the eighteenth century, which saw more and more collectors and writers adopt its scheme. Goethe’s Wilhelm Meister's

\footnotetext{
${ }^{67}$ Quoted in Hajós, p. 155, ‘disposées en bon ordre, soit qu’on les arrange par les œuvres des Maîtres ou qu’on les dispose par les sujets differens.’

${ }^{6}$ Hajós, p. 155.

${ }^{69}$ Robinson, p. xxxvii.

${ }^{70}$ ibid, p. xxxiii.

${ }^{71}$ Sandrart, pp. 316-318.

${ }^{72}$ Robinson, p. xxxiii.

${ }^{73}$ ibid.
} 
Apprenticeship (1795) emphasises the importance of art history for a print collection, which should be arranged in a chronological progression: in the book the character 'Schöne Seele' says that her uncle tried to make her see that 'only the study of the history of art can give us a proper sense of the value and distinction of a work of art. ${ }^{, 74}$ Goethe himself owned an extensive print collection, originally arranged according to subject, but which he reorganised after 1805 according to schools and artists in historical order. ${ }^{75}$ Florent Le Comte, in his third section of a print collection, also advocated a chronological presentation of the works, 'In order, by that Means, to observe their Original, Increase and Decay; and lastly, their Re-establishment in the Perfection and Beauty we now see them. ${ }^{, 76}$ Antony Griffiths states that the collections of the art-loving princes of the early decades of the eighteenth century were generally focused on presenting a history of art, and even the print dealers in Paris arranged their stock by maître (master), enabling collectors to form oeuvres of each. ${ }^{77}$

\section{Carl Heinrich von Heineken’s Idée générale d'une collection complette d'estampes} (1771) is a manual for print collections, based on his experience as director of the Salon d'Estampes in Dresden, which also applied a historical method. ${ }^{78}$ His system consists of twelve classes, five of which are devoted to prints; these are arranged according to schools, namely Italian, French, Flemish and Dutch, English and German. Within each school, he presents a succinct summary of the origins of each print media and its development within the school, followed by an alphabetical list of artists' names, as this order seemed 'most suitable to help one's memory, and to find artists, whenever one is looking for someone in particular. ${ }^{79}$ Still, the next four classes are once again structured by subjects, which illustrates well Roger de Piles’ recognition of the cohabitation of these two methods.

In his essay 'Of the Usefulness and Use of Prints' (1699) de Piles describes three types of collectors, as 'the order and choice that is to be observed, depend on every

\footnotetext{
74 Johannes Grave, 'Ideal and History: Johann Wolfgang Goethe’s collection of prints and drawings', Artibus et Historiae, 27 (53), 2006, p. 175.

75 ibid, p. 178.

${ }^{76}$ Florent Le Comte in Sculptura historico-technica: or, the history and art of engraving, p. 111.

${ }^{77}$ Antony Griffiths, 'Print Collecting in Rome, Paris and London in the early eighteenth century', Harvard University Art Museums Bulletin, 2 (3), 1994, pp. 37-38.

${ }^{78}$ Hajós, p. 155.

${ }^{79}$ Carl Heinrich von Heineken, Idée générale d'une collection complette d'estampes: avec une dissertation sur l'origine de la gravure et sur les premiers livres d'images, Leipzig and Vienna: Jean Paul Kraus, 1771, p. 3, 'le plus convenable pour subvenir à la mémoire, \& pour trouver les artistes, quand on en cherche quelqu'un.'
} 
man's Gout [Taste] and views. ${ }^{80}$ The first is the lover of history, who collects prints with educational benefits, such as portraits, maps and everything else that bears on history. ${ }^{81}$ The second has a passion for the fine arts and arranged his volumes within each school by masters. ${ }^{82}$ He does not differentiate between the two groups, making one type out to be better than the other. But rather, he acknowledges that both of these methods are now common and acceptable. The third type however, which de Piles only mentions briefly, is a collector who amasses prints according to the engraver, with no respect to the painters who might have designed the original image. ${ }^{83}$ This is actually a new development, which only truly emerged during the late eighteenth century. Whenever reproductive prints, that is prints made after another painting, had previously been grouped under the name of a 'master', these masters would have been the painters/designers of the original image, not actually the printmakers. The fact that de Piles mentions such a collector by the turn of the century is proof that engravers, the ‘craftsmen’, were already acknowledged by some. By 1768 William Gilpin was still placing the painters over men like Marcantonio, who merely copied the works of Raphael and did not produce anything of his own invention, making him and his fellow engravers 'little better than mere mechanics. ${ }^{84}$ He writes: 'Their execution is harsh, and formal to the last degrees; and if their prints give us any idea of the works of RAPHAEL, we may well wonder, [...] how that master got his reputation. ${ }^{85}$ It was Pierre-François Basan’s Dictionnaire des Graveurs (1767), however, which was the first published book arranged by engravers, though still only limited to the ones mentioned in previous literature. ${ }^{86}$ While this might have been the early beginnings of the modern practice of placing emphasis on printmakers (not designers), the true revolutionary in this area only came onto the scene during the next century.

\footnotetext{
${ }^{80}$ Roger de Piles, 'Of the Usefulness and Use of Prints', in The Art of Painting, with the Lives and Characters of above 300 of the Most Eminent Painters, 3rd edition, London: T. Payne and Sons, 1754 [1699], p. 56.

81 ibid, pp. 56-57.

82 ibid, p. 57.

83 ibid.

${ }^{84}$ William Gilpin, An essay upon prints, London: J. Robson, 1768, p. 54.

${ }^{85}$ Gilpin, pp. 77-78.

${ }^{86}$ Griffiths, 'Print Collecting in Rome, Paris and London in the Early Eighteenth Century', p. 52.
} 


\section{The Nineteenth and Twentieth Centuries}

of all the different departments in the whole range of art, or nature [...] which a person can select, in which to form a collection, the preferable pursuit, in all these essential respects, is the collecting of prints. ${ }^{87}$

In the Introduction to The Illustrated Bartsch (1978) Walter Koschatzky writes that 'Anyone who dedicates his efforts to collecting, [...] or to attempting to understand graphics in particular, must turn time and again to the works of Adam von Bartsch as an invaluable source of information. ${ }^{88}$ One could even go further by saying that Bartsch's enormous twenty-one-volume opus Le Peintre-Graveur (1803-1821) was the single most influential catalogue of printmakers ever written; its system of organisation still persists in public and private print collections today, and its principles retain their significance in establishing original prints as autonomous works of art of the highest level. ${ }^{89}$ The classifications underlying the Peintre-Graveur, namely organising its contents by schools and within these listing the about 500 artists' names alphabetically, had already been used in his earlier Catalogue raisonné des dessins originaux $d u$ Cabinet de feu Le Prince Charles de Ligne (Vienna, 1794). While in principle Le Peintre-Graveur was similar to Basan's Dictionnaire des Graveurs, the title of Bartsch's work already indicated that he was going further than anyone before him, by limiting his interests to engravings created by famous painters after their own designs and thus omitting reproductive prints completely.

Through an analogy with translation, Bartsch demonstrated the inferiority of the reproductive print, by pointing out that the best reproduction/translation would be the one produced by the printmaker/translator who had managed to enter most fully the mind of the original artist. ${ }^{90}$ Naturally, this would be the artist himself. As Michael Bury states, Bartsch was obviously trying to imply that 'the finest prints are those that consistently demonstrate the expressive powers of a single personality'. ${ }^{91}$ Thus, when discussing the effects of shadows created in engravings in his Anleitung zur Kupferstichkunde (1821), Bartsch wrote, for example, that 'Painters, who have mastered this part of the art through long exercise with a brush on the canvas, will most certainly

\footnotetext{
${ }^{87}$ Joseph Maberly, The print collector: an introduction to the knowledge necessary for forming a collection of ancient prints, London: Saunders and Otley, 1844, p. 2.

${ }^{88}$ Walter Koschatzky, 'Adam von Bartsch: An Introduction to his Life and Work', in Walter L. Strauss (ed.), The illustrated Bartsch, New York: Abaris Books, 1978, p. xvii.

${ }^{89}$ ibid, p. xvii.

${ }^{90}$ Bury, p. 26.

${ }^{91}$ ibid.
} 
achieve the same on copper. ${ }^{92}$ Artists like Rembrandt or Jan Verkolje, in their dual roles of painters and engravers, thus became prototypes of the 'peintre graveur' ${ }^{93}$ His approach worked particularly well for fifteenth- and sixteenth-century German and Flemish artists, as the reproduction of a picture or drawing in engravings or woodcuts was less common in the North. ${ }^{94}$

Therefore, by shifting the main emphasis to engraving as an independent branch of art, with the capacity for unique artistic expression, Bartsch granted to the printmaker according to Walter Koschatzky 'an importance usually reserved to the painter, as if the engraver could properly claim to belong to the category of an original thinker, freely executing his own artistic ideas. ${ }^{95}$ Printmakers had finally reached the highest status possible in the hierarchy of the arts; a status which acknowledged their artistic, individual genius and which they have retained until the present day. It is interesting to note that Bartsch's ideas only began to truly dominate print history from the second half of the nineteenth century onwards which might be directly linked to the invention of photography. This medium emerged during the middle decades of the century and by providing a cheaper and faster reproductive method, it led ultimately to the destruction of the reproductive engraver's livelihood. ${ }^{96}$ Photography practically reinforced Bartsch's arguments by demonstrating the lack of imagination needed for reproduction, and subsequently highlighting the genius and talent of original engravers.

Eventually the Peintre-Graveur was to be included among the official textbooks at all French universities and libraries. ${ }^{97}$ The acceptance of his manual at such a level shows the influence it exerted, which reached, even indirectly, the arrangement of virtually all the nineteenth-century collections in existence or in the planning stages. ${ }^{98}$ He made the systematic build-up of collections possible. At the same time, one might even claim that it was the emergence of catalogues in general, practically a new genre at the time, which literally influenced what prints were being collected. Catalogues like the Peintre-Graveur or some of Bartsch's earlier catalogues raisonnés, such as the ones on

\footnotetext{
${ }^{92}$ Adam von Bartsch, Anleitung zur Kupferstichkunde, Vienna: J. B, Wallishausser, 1821, p. 81, 'Mahler, die diesen Theil der Kunst mit dem Pinsel auf der Leinwand durch lange übung sich eigen gemacht haben, kommen am sichersten dahin, ihn auch auf dem Kupfer zu bewirken.’

${ }^{93}$ Koschatzky, p. xiv.

${ }^{94}$ Muriel Clayton, The Print Collector, London: Herbert Jenkins Limited, 1929, p. 30.

${ }^{95}$ Koschatzky, p. xvi.

${ }^{96}$ Griffiths, 'Print Collecting in Rome, Paris and London in the early eighteenth century', p. 53.

${ }^{97}$ Koschatzky, p. xv.

${ }^{98}$ ibid.
} 
Rembrandt (1797) and Lucas van Leyden (1798), provided collectors with the complete oeuvre of a particular artist. Hence collectors like John Sheepshanks (1787-1863) displayed a new 'philatelic' mentality; that is a desire to complete a series taken from a particular catalogue. ${ }^{99}$ Sheepshanks, for example, used Bartsch as a guide, while at the same time putting himself the task to buy works so rare that Bartsch himself had not seen them. ${ }^{100}$

By 1844, when Joseph Maberly published his book The print collector: an introduction to the knowledge necessary for forming a collection of ancient prints, Bartsch’s approach had entered into mainstream print literature, as Maberly matter-offactly included it in his discussion of the various arrangements available for print collectors. Maberly writes: 'These observations suggest a further subdivision, or department, in classification, namely, the ranging together the works of all artists who have been their own engravers.' ${ }^{101}$ He also recognises the superiority of Northern artists in this field, claiming that 'At the head of these may, perhaps, be placed Martin Schoen, [...followed by...] Albert Durer; [...] not to mention the more important artist, Rembrandt'. ${ }^{102}$ Print collecting had obviously become a very selective practice indeed, a fact which Maberly's handbook supports even further when he tells the collector to significantly limit the number of artists and works to be included in a collection:

We would recommend that a list be drawn up of a certain number of artists, some one or more of whose works, but no others, should be admitted into the collection; and we would recommend that this list contain such artists only as are of prominent importance, taking care, however, to include such as mark areas in the art, and such as have invented or introduced new methods of working [...] We would advise the young collector to [...] confine himself to a very few specimens of each artist in it: in many cases one single specimen would suffice. $^{103}$

The seventh chapter of his book works through each school in turn and he actually selects the best engravers within each. This trend, which advocated collecting nothing

\footnotetext{
${ }^{99}$ Martin Royalton-Kisch, 'John Sheepshanks (1787-1863) and his Dutch and Flemish Etchings', in Antony Griffiths (ed.), Landmarks in Print Collecting: Connoisseurs and Donors at the British Museum since 1753, London: British Museum Press, 1996, pp. 65-89, p. 76.

${ }^{100}$ ibid.

${ }^{101}$ Maberly, p. 24.

102 ibid.

${ }^{103}$ ibid, pp. 118-119.
} 
but the best impressions of the best works of the best engravers, became part of a completely new collecting world.

In fact, the further we look back into history, the more widely we find that people collected. ${ }^{104}$ Mark P. McDonald argues, for example, that Ferdinand Columbus had collected anything he could get his hands on. ${ }^{105}$ By the end of the seventeenth century the areas of interest were becoming narrower, and by the twentieth century the number of great printmakers and the canon of the best prints had become very limited. ${ }^{106}$ Quantity and completeness were of no importance anymore. Felix Slade (1790-1868) only amassed a few examples of each notable printmaker, with striking selectivity and a restraint which was part of a conscious strategy. ${ }^{107}$ Antony Griffiths elaborates that his approach was typical during the nineteenth century: 'The great growth in this type of collecting seems to lie in the 1820s and 1830s. Lists of the finest works by the best engravers go back a long way in the literature of print collecting, but recommendations that a collection need only contain these works seem to be a new phenomenon. ${ }^{108}$ Maberly was the first writer to take this approach in Britain, while the earliest attempts of advocating this scheme can be attributed to the Italians. ${ }^{109}$ Giuseppe Longhi’s La Calcografia (1830) was among the first to claim that: 'In limiting the number of the best engravers here recorded, they can show their best productions one by one, resulting on the whole in a modest, yet choice collection of prints. ${ }^{, 110}$

One might argue that this new selective attitude towards prints was due to the increasingly limited number of prints available to private collectors, as they started to encounter fierce competition in their collecting practices. Maberly explained the scarcity of old master prints with the collecting activities of public institutions: 'National collections are now forming by governments, who never, till lately, turned their attention to the subject; and, again, in those states which have of old had

\footnotetext{
${ }^{104}$ Antony Griffiths (ed.), Landmarks in Print Collecting: Connoisseurs and Donors at the British Museum since 1753, London: British Museum Press, 1996, pp. 16-17.

${ }^{105}$ Mark P. McDonald, Ferdinand Columbus: Renaissance Collector (1488-1539), London: British Museum Press, 2005, p. 25.

${ }^{106}$ Griffiths (ed.), Landmarks in Print Collecting, p. 17.

107 ibid, p. 117.

108 ibid, p. 118.

109 ibid.

${ }^{110}$ Giuseppe Longhi, La Calcografia propriamente detta ossia l'Arte d'Incidere in Rame coll'Acqua-forte, col Bulino e colla Punta ... Volume I, concernent la Teoria dell'arte, Milano: Stamperia Reale, 1830, p. 255, 'Nel ristretto numero dei migliori calcografi qui registrati furono di mano in mano indicate le più felici loro produzioni, formanti in complesso una modica, ma scelta collezione di stampe.'
} 
depositories, great activity and interest have, of late years, succeeded a long course of apathy and indifference. ${ }^{111}$ He claims that a third of the first one hundred articles listed in the catalogue Notice des Estampes exposés a la Bibliothèque Royale, which included the whole of the fifteenth and sixteenth centuries, had been acquired since the year 1800, while the collection had in fact already been founded in $1667 .{ }^{112}$ The British Museum is another good example of museums' increasing interest in purchasing prints. The Department of Prints and Drawings was only established as an independent department in 1837, having previously been a part of the Departments of Manuscripts and of Printed Books. ${ }^{113}$ While no money was spent on purchasing new additions to the Department during the eighteenth century, in 1827 it was allocated an annual allowance for this purpose; an allowance which increased rapidly. ${ }^{114}$ Griffiths explains that:

It was not simply that the Department acquired a series of prints of the greatest rarity and importance. They were a decisive statement of intent. The British Museum had stopped being a collection of merely national and thus provincial importance; it has raised its sights and intended to become of international stature. This new ambition infected the Trustees, and they began to raise the annual grant for the Department's bread-and-butter purchases. ${ }^{115}$

Even in the twentieth century this was still an issue for private collectors, as Muriel Clayton, writing in 1929, maintained that well-chosen prints are never likely to lose their value, seeing that the world's supply is limited, and prints are becoming more and more absorbed in public galleries and institutions. ${ }^{116}$

\section{A final significant contribution by Maberly's Print Collector is a list of collectors} and reproductions of their individual collector's marks at the end of the fourth chapter. While earlier writers, starting with Vasari, had written on different artists’ monograms before, now the monograms of collectors became significant. As Maberly explained, these became a vital tool in establishing a print's provenance: 'By means of these marks of proprietorship, the transmission of an identical impression may, sometimes, be traced for a considerable period of time. ${ }^{117}$ He further expounds that a known provenance not

\footnotetext{
111 Maberly, p. 157.

112 ibid, p. 158.

${ }^{113}$ Griffiths (ed.), Landmarks in Print Collecting, p. 11.

114 ibid, p. 12.

115 ibid, pp. 12-13.

${ }^{116}$ Clayton, p. 258.

${ }^{117}$ Maberly, p. 85.
} 
only helps to authenticate a piece, but it may carry sentimental value by creating a direct link to the people who have come before the current owner:

it excites much additional interest, that we are now seeing, handling, and admiring the same identical thing which was seen, handled, and admired by our ancestors, or at least the ancestors of our generation, several centuries ago. I hold in my hand, perhaps, at this moment, the same print, certainly the same virtually, but possibly the same identical piece of paper, that Marc Antonio held in his hand ${ }^{118}$

Collector's marks emerged in the eighteenth century, partly because an unbroken provenance served as a guarantor of attribution, and also because they served to enhance a collector's prestige within a social network. ${ }^{119}$ Again, this interest in the collector's mark persisted until the twentieth century, when Clayton confirmed that a true lover of prints 'is interested, not merely in the pictorial and technical aspects of the print itself, but in the paper and in any marks or notes that it may bear. Very often he will find in the margin or on the back some name or monogram or cipher denoting a previous, and often old, ownership., ${ }^{120}$ She also referred the reader to one of the earliest and most substantial studies on the topic, F. Lugt's Les Marques de collections de dessins et d'estampes (1921), which identified collectors' marks and stamps on drawings and prints, while also including a short descriptive biography of each owner and their collection. $^{121}$

Finally, while these last two centuries had witnessed an increasingly selective approach towards print collecting, the original canon of Northern printmakers had persisted. Other artists had joined their ranks over the centuries, such as the French lineengravers of the later 1700s, whose works had come into high demand among collectors during the twentieth century. ${ }^{122}$ Yet there are some names that have never gone out of favour, including many of the German and Flemish Renaissance printmakers. In addition to this, there was one other area which received a great deal of attention during the twentieth century, which had previously been neglected by collectors and critics alike: the early Northern woodcut. While woodcuts by renowned artists like Dürer and

\footnotetext{
${ }^{118}$ Maberly, p. 14.

${ }^{119}$ Baker, Elam and Warwick p. 5.

${ }^{120}$ Clayton, p. 261.

121 This work is now available online and is updated continuously.

${ }^{122}$ Alfred Whitman, Whitman's Print-Collector's Handbook, 6th edition, Malcolm C. Salaman (ed.), London:

G. Bell and Sons, Ltd, 1921 [1901], p. vii.
} 
Cranach always found a place among collectors' items, due to their authorship, the woodcuts made before the arrival of Dürer, for example, were never included in Bartsch. ${ }^{123}$ Now prints by artists like Michael Wolgemut are considered equally valuable as those by men such as Heinrich Aldegrever. Clayton explains that an increased regard for the expressive qualities of the medium, demonstrated by modern artists, has contributed to a newfound interest in woodcuts: 'the modern achievement in the revival of the woodcut [Thomas Bewick and Edward Calvert], both in France and England, must necessarily cause the collector to think more closely about the sterling value of the past masterpieces from the wood-block'. ${ }^{124}$

In conclusion, while Northern Renaissance prints were being collected for practical and educational purposes in artists' workshops ever since their production, systematic collecting of prints by non-practitioners only began during the later sixteenth century and eventually developed into the art historical approach practiced today. Whereas encyclopaedic collections continued during the seventeenth and early eighteenth centuries, the focus was gradually shifting towards organising collections under artists' names, chronologically or alphabetically, which contributed to the recognition of the print as an independent and original art form. A canon of the master printmakers was created almost immediately, which appears to have lasted until now and includes a mixture of Italian and Northern artists. The most influential change to this list occurred in the nineteenth century, when reproductive printmakers were shunned from the ranks of original artists. Names like Dürer and Lucas van Leyden, however, never really lost their pre-eminence.

The next chapter will look at the lives and collecting practices of Bishop Monrad and Sir John Ilott, whose donations from their private print collections formed the foundation of Te Papa's collection of Northern European prints from the fifteenth and sixteenth centuries. Other collectors who have contributed to this collection, but who have largely remained unrecognised until now, will also be considered.

${ }^{123}$ Griffiths (ed.), Landmarks in Print Collecting, p. 159.

${ }^{124}$ Clayton, pp. 34-35. 


\section{Chapter Two: The Collectors}

More than half of the 164 prints that have been analysed for the purpose of this research were donated either by Bishop Monrad (61 prints) or Sir John Ilott (35 prints). These two collectors and their bequests undoubtedly make up the heart of Te Papa's print holdings today. ${ }^{1}$ By examining and comparing their lives and collecting habits, one can find both parallels and differences in their respective approaches to print collecting. Even though they collected at different times and in different locations, one in nineteenth-century Denmark and the other in twentieth-century New Zealand, it appears that their manner of acquisition was indeed quite similar. Also, both of them extended their collecting activities beyond prints by amassing collections of other objects as well. One should further consider the reasons which motivated them to start collecting in the first place and why they chose to collect Northern European prints of the fifteenth and sixteenth centuries. In addition to this, other collectors who contributed to Te Papa's print collection will be mentioned, as well as the means by which the museum itself bought prints directly, in order to provide a broader understanding of how today’s collection of Northern Renaissance and Mannerist prints came to Te Papa.

\section{Bishop Monrad (1811-1887) and his Collection}

Denmark lost a noble spirit when the ex-Minister left, - New Zealand gained one when he landed on its shores; may the acquisition be prized and turned to account. ${ }^{2}$

Ditlev Gothard Monrad was born 24 November 1811, in Copenhagen. He attended the theological school at the University of Copenhagen in 1830, following in the footsteps of his foster-father Lauritz Westengaard, who was a teacher and clergyman. ${ }^{3}$ It was also at university that his political ambitions were motivated: he became actively involved in the liberal movement and the resurgence of patriotism, as well as political stirrings in general, which were most evident at the universities. ${ }^{4}$ In 1840 he became chief editor of Faedrelandet, a national liberal newspaper established in 1834 to support

\footnotetext{
${ }^{1}$ There are two important theses written on the print collections of these collectors: Mathew Norman, The print collection of Bishop Monrad (1811-1887), M.A. diss., Wellington: Victoria University of Wellington, 2006; and Julianne Malpas, An incurable collector: Sir John Ilott (1884-1973) and his passion for prints, M.A. diss., Wellington: Victoria University of Wellington, 2005.

${ }^{2}$ Rev. Richard Taylor, The past and present of New Zealand: with its prospects for the future, London: William Macintosh; Wanganui: Henry Ireson Jones, 1868, p. 261.

${ }^{3}$ Petersen, G. C., D. G. Monrad: scholar, statesman, priest and New Zealand pioneer and his New Zealand descendants, Levin: Kerslake, Billens and Humphrey, 1965, p. 15.

4 ibid, p. 16.
} 
the struggle for a free constitution. However, as the tension between Denmark and Germany over the duchies of Slesvig and Holstein increased, his writings were suppressed and he accepted the position as pastor in the small country parish of VestlevUlslev, Lolland, and moved there with his family in 1846. This was the beginning of a unique pattern in his life: whenever he was dealt a harsh blow in the world of politics, he would retreat to a small town in order to pursue his religious calling, only to be caught up again by the political issues that plagued his country.

On 31 December 1863 Monrad became Prime Minister in a new cabinet which the King had asked him to form. This meant that he was held responsible for the outcome of the on-going war with Germany, and when a truce was reached on 8 July 1864, after Denmark had suffered substantial losses, he was dismissed and shortly afterwards embarked on a non-stop over four month long voyage on the sailing ship Victory to New Zealand, on 14 December 1865. He saw no future for Denmark and thus sought to build a future for his sons elsewhere: 'The Danish People stood before me as deceased, and Denmark was for me as a corpse. I pressed a burning kiss on the forehead and left it'. ${ }^{5}$ The Monrad family finally settled at Karere, Palmerston North, where they lived and worked the land for three years. Monrad was convinced that he had made the right decision: 'We have hopes that there is a good prospect for our sons here. There is much work to do in this beautiful country. ${ }^{6}$ While it had been clear from the very beginning that Monrad and his wife Emilie would eventually return to Denmark, their departure came sooner than they had thought, as Maori unrest in Taranaki had escalated and the Hauhau were on a warpath against white settlers living on confiscated land. Soon reports of killings and assaults reached the otherwise peaceful Karere. ${ }^{7}$ Monrad, Emilie and their daughters set sail for London on 10 January $1869 .^{8}$

While Monrad and his descendants certainly played a significant role in developing the native landscape of New Zealand during its early settlement, he is mostly remembered for the generous gift of 599 fine prints he gave to the nation shortly before

\footnotetext{
${ }^{5}$ Nina Damsgaard and Signe Jacobsen (eds.), D. G. Monrad: en kunstsamler i 1800-tallet, Vejle (Denmark): Vejle Kunstmuseum, Nivå (Denmark): Nivaagaards malerisamling, 1992, p. 62, 'Det danske Folk stod for mig som en Afdod, og Danmark stod for mig som et Lig. Jeg trykkede et brændende Kys paa dets Pande og forlod det ...'

${ }^{6}$ Petersen, p. 108.

${ }^{7}$ Damsgaard and Jacobsen, p. 92.

${ }^{8}$ For a more detailed account of Monrad's life, see especially G. C. Petersen, D. G. Monrad: Scholar, Statesman, Priest and New Zealand Pioneer and his New Zealand Descendants, Levin: Kerslake, Billens and Humphrey, 1965; and Johan Schioldann-Nielsen, The life of D.G. Monrad, 1811-1887: manic-depressive disorder and political leadership, Odense (Denmark): Odense University Press, 1988.
} 
his departure in 1869. This was 'the earliest European print collection to be donated to a public institution outside Europe. ${ }^{9}$ Two days before leaving New Zealand Monrad wrote to the Colonial Secretary: 'Sir, I have the pleasure to offer to the Colonial Museum ${ }^{10}$ a small collection of Etchings and Engravings, hoping it will be accepted and taken good care of. Your obedient servant, D. G. Monrad., ${ }^{11}$ Before looking at the collection itself and how Monrad had acquired it in the first place, it is worthwhile to consider the motivations for this gift. One cannot know for certain why Monrad chose to leave this substantial collection of prints here, which, as Petersen points out, would have been a significant sacrifice for him:

These were the works he [...] had delighted to collect in the pleasant years before the catastrophe of 1864 and which he had chosen to take with him into exile as something of the culture of his homeland. They were undoubtedly his most valuable personal possession and he well knew that his advancing years and uncertain financial position would render it impossible for him to assemble again such an extensive collection. ${ }^{12}$

Monrad himself called them his 'dear faithful friends'. ${ }^{13}$ One possible explanation is proposed by Mathew Norman, who suggests that the donation was a way for Monrad to pay off debts which he had incurred during his stay in New Zealand. ${ }^{14}$ While Petersen had highlighted that Monrad 'was disinclined to accept favours that he felt placed him under too great an obligation to the Government', ${ }^{15}$ there is no doubt that the family had relied on some favours from generous benefactors. Sir George Grey, for example, had suggested that both of Monrad's sons should accept commissions in the militia, as this would entitle them to 200 acres of land each at Patea, free of charge. ${ }^{16}$ This offer was accepted, and there is reason to believe that Monrad was forced to take on monetary debts as well. A letter from 29 December 1867 indicates that he was seriously

\footnotetext{
9 'European Master Prints: The founding gift of Bishop Monrad', ttp://www.tepapa.govt.nz/WhatsOn/ exhibitions/Pages/EuropeanMasterPrintsthefoundinggiftofBishopMonrad.aspx.

${ }^{10}$ The Colonial Museum was opened in December 1865 and became Te Papa's first predecessor. In 1907, the Museum became known as the Dominion Museum.

${ }^{11}$ Petersen, p. 115.

12 ibid, p. 116.

13 ibid, p. 105.

${ }^{14}$ Mathew Norman, The print collection of Bishop Monrad (1811-1887), M.A. diss., Wellington: Victoria University of Wellington, 2006, p. 12.

${ }^{15}$ Petersen, p. 79.

${ }^{16}$ ibid.
} 
considering selling the print collection to the colonial government as an alternative to selling his Karere property, presumably to aid with such financial obligations. ${ }^{17}$

A more romantic, but nonetheless valid, assumption is that Monrad donated the prints as a manner of expressing his gratitude to New Zealand and its residents who had welcomed and aided his family when they were in need. Peter Vedel, who wrote a biography of Monrad in 1904 based on information he had received from Monrad's son Viggo, wrote: 'As an expression of his gratitude for the hospitality he had received in Wellington, Monrad donated to the present Museum a large selection of his collection of engravings, one of the few things he had brought from Karere. ${ }^{18}$ Monrad himself expressed more than once his kind feelings towards the country. In a letter to the Danish King on 1 May 1867 he wrote: 'I have met with much benevolence over here, much more than I could reasonably expect ${ }^{19}$, and later he stated: 'it raised my spirits to live in this sublime, untamed nature, and to use a spade in ground which had lain untouched since creation ... I lived happy years in New Zealand'. ${ }^{20}$ Despite all the setbacks he had encountered here, New Zealand had received him warmly when his own countrymen had rejected him, and he left knowing that his sons' future was secured. What better way to show his gratitude than to leave part of his most valuable possession behind, so that New Zealanders might take delight in them as he had once done?

Still, one can easily empathise with Signe Jacobson's statement that Monrad's active career as a politician and his religious vocation as bishop should rule out the possibility for him to even have the time necessary to concern himself with art, yet alone generate a passion for it that leads to a collection. ${ }^{21}$ Even before his life became constantly caught up between his political and religious professions, there appears to have been no indication of his later collecting activities. In his essay 'Psychological aspects of art collecting', Frederick Baekeland raised the question whether art collectors can already be identified as children, as child collectors are a very rare occurrence. ${ }^{22}$ However, there is no evidence to suggest that Monrad had already been collecting during his childhood,

\footnotetext{
${ }^{17}$ Norman, pp. 9-10.

${ }^{18}$ Quoted in Damsgaard and Jacobsen, p. 97, 'Som et Udtryk for sin Tak for den Gæstfrihed, han havde mødt i Wellington, skænkede M. det derværende Museum et stort Udvalg af sin Samling af Raderinger, en af de faa Ting, han havde medtaget fra Karere.'

${ }^{19}$ Schioldann-Nielsen, Johan, The life of D.G. Monrad, 1811-1887: manic-depressive disorder and political leadership, Odense (Denmark): Odense University Press, 1988, p. 144.

${ }^{20}$ Quoted in Schioldann-Nielsen, p. 146.

${ }^{21}$ Damsgaard and Jacobsen, p. 21.

${ }^{22}$ Frederick Baekeland, 'Psychological aspects of art collecting', in Susan Pearce (ed.), Interpreting objects and collections, London; New York: Routledge, 1994, pp. 205-219, p. 207.
} 
which after all had been deeply distressing and marked by his struggle to cope with the absence of his parents. Thus, when his own life and personality do not appear to have fostered an interest in art collecting, one must wonder where this fascination came from. Apparently Monrad received this inspiration mainly from two specific people: his wife Emilie and his friend Høyen.

Emilie grew up in a highly cultivated family home, where she and her sisters received an ample education about art, music and literature. ${ }^{23}$ From letters which Monrad wrote to Emilie, one can determine that he did not experience art properly without her; already on the journey to Paris for his scholarship in 1838 he wrote: 'You do not have to be afraid of me forgetting you, for through your eyes I perceive Nature , Art and People'. ${ }^{24}$ From Paris he wrote 'I have no pleasure in what is ever so nicely if I cannot enjoy the fellowship with thee, my dear Emilie' ${ }^{25}$, and from Germany in 1843 'When I see paintings would I willingly have you with me'. ${ }^{26}$ From this one gets the impression that Monrad's own abilities did not naturally lean towards art and natural beauty, but rather were introduced to this world by Emilie, which is why Signe Jacobsen suggests that there is no reason to believe that Monrad increased his collection of art in any significant degree after her death in $1871 .^{27}$

While Emilie had definitely influenced Monrad's passion for art, this seems to have been restricted mainly to the domain of painting and drawing. Like Monrad himself, Emilie had been closely associated with numerous artists of the Danish Golden Age, such as Constantin Hansen, whose works the couple collected together. The vast amount of correspondence exchanged between Emilie and Hansen testifies to their close relationship; in their letters they discussed the latter's artworks, and Hansen would even tell Emilie of the sorrows he faced as an artist. Hansen once wrote to Emilie for example 'I and my eyes were in those days a little tired of pencil drawings, so I have painted a small portrait alla prima, which I can do exactly in the same time needed to execute a pencil drawing, and hope that you will be pleased with the alternate.', and in a letter from 29 October 1852 he complains to her about the lack of public interest in

\footnotetext{
${ }^{23}$ Damsgaard and Jacobsen, p. 24.

${ }^{24}$ ibid, p. 25, 'Du behøver rigtig- nok ikke at være bange for at jeg skal glemme dig, thi gjennem Dine Briller seer jeg Natur, Kunst og Mennesker'.

${ }^{25}$ ibid, 'jeg kan ikke have nogen Fornøjelse af hvad der er nok saa smukt, naar jeg ikke nyder det i

Samfund med Dig, Du min kjære Emilie!’

${ }^{26}$ ibid, p. 99,' Naar jeg seer Malerier vild e jeg gjerne have Dig med mig’.

${ }^{27}$ ibid.
} 
pencil drawings: 'the season is not favorable to small pencil drawings'. ${ }^{28}$ Unlike the Monrads' collection of such drawings and paintings, which was undoubtedly a joint project, the engravings collection appears to have been more Monrad's domain than Emilie’s.

The other influential person who awakened Monrad's passion for art, and who became both his agent and taste-setter, was the art historian Niels Laurits Andreas Høyen (1798-1870). Monrad would have met him frequently at the house of the Westgaards, seeing that Lauritz Westgaard’s wife was Høyen’s sister, and after 1832 their family ties became even stronger with the marriage of Westergaard's sister Gitte to Høyen. In a 1846 letter Monrad admits that he thought of Høyen as family as well: 'you are really the only family that we [me and Emilie] have had [in Copenhagen], ${ }^{29}$ Høyen is known for singlehandedly founding art history as a branch of Danish scholarship; he had no predecessors in this field and taught himself mainly by undertaking a study tour around Germany and Italy (1822-25). ${ }^{30}$ He further travelled systematically around Denmark to study the national medieval and Renaissance architecture, church fittings, art collections, and so on. ${ }^{31}$ He was 'romantically patriotic' and among other things was responsible for arranging the large national-historical portrait gallery at Frederiksborg Castle and administering the royal collection of pictures, which later became the State Museum of Art. From 1829 he lectured regularly at the Royal Danish Academy of Fine Arts and by 1856 he had become lecturer at Copenhagen University. Denmark: an official handbook indicates that this provided him with the opportunity to propose a truly national Danish art: 'At these institutions he advocated a national-romantic, Scandinavian programme: artists should choose subjects from Danish popular life or Scandinavian mythology and history. ${ }^{32}$ It is therefore not surprising to learn that Monrad was introduced to numerous painters who later became active participants of the Danish Golden Age of painting at Høyen's home during the 1830s; these artists, whose works Monrad later collected together with Emilie, included J. Th. Lundbye, Christen Købke, Constantin Hansen and P. C. Skovgaard. ${ }^{33}$

\footnotetext{
${ }^{28}$ Damsgaard and Jacobsen , p. 45, 'Aarstiden (ikke) er gunstig for smaa Blyantstegninger'.

29 ibid, p. 40, ' thi I er da egentlig den eneste Familie, som vi have havt, hvad man kan kalde Omgang med'.

${ }^{30}$ Rying, Bent (ed.), Denmark: an official handbook, $14^{\text {th }}$ edition, Copenhagen: Krak, 1970, p. 538.

${ }^{31}$ ibid, p. 538.

32 ibid.

33 Damsgaard and Jacobsen, p. 22.
} 
Just as Maberly had proposed in The print collector (1844), Høyen became Monrad's 'competent private friend', a sort of agent, who helped and advised him when buying prints. While one can assume that Monrad had started collecting prints during the 1830s, from correspondence one can gather that he became seriously involved only after he had gone to Vestlev-Ulslev in 1846. While he and his family were said to have missed the cultured life of the capital the most during their time there, the portability of the print medium enabled him to continue his collection even in remote places. He had dealers send him catalogues of prints and etchings, from which he then selected the ones he desired and ordered them through his friend Høyen. ${ }^{34}$ On 18 December 1846, for example, he wrote to Høyen

So now my request for you is that you will help me to make a selection for 100 Thalers and order, what I want, at Delbanco [the book-dealers Lose \& Delbanco] and introduce the prices. I would like to draw your attention to the following numbers; the order in which they stand, represents approximately the place they occupy in my desires, but because I, in my ignorance, do not trust in the righteousness of my own judgments, I ask that you feel free to act as an absolute monarch and embarrass yourself like CVIII [Christian VIII]. ${ }^{35}$

From this and other letters, one can deduce that Monrad did not really know what he was doing during this early phase of collecting, and Høyen acted as his mentor, introducing him to the major artists, identifying the abbreviations of their names and evaluating their artistic value. ${ }^{36}$

This relationship reflects the ideas expressed by Maberly, who was convinced that a love for prints was not enough to start building up a collection, but rather advised the young collector that

he must, until he can obtain experience for himself, purchase or beg the fruit of the experience which others have acquired [...] instead of assuming to judge for himself, in which case he is sure speedily to betray his ignorance [...] It must not be concealed, that the experience requisite to enable an aspirant to go alone is very considerable, and, indeed, there are few

\footnotetext{
${ }^{34}$ Petersen, p. 30.

${ }^{35}$ Damsgaard and Jacobsen, pp. 38-39, 'Saa nu er det da min Begjæring til Dig, at Du vil hjælpe mig med at gjøre et Udvalg for 100 Thaler og bestille, hvad jeg skal have, hos Delbanco og indføre Priser- ne. Paa nedenstaaende Numre vil jeg henlede din Opmærksomhed; Ordenen, hvori de staaer, beteg- ner omtrent den Plads, de indtage i mine Ønsker; men da jeg paa Grund af min Uvidenhed ikke selv har ret Tillid til mine Ønskers Rigtighed, saa bedes du at handle som uindskrænket Monark og genere Dig ligesaalidt som CVILI (Christian den ottende ).'

36 ibid, p. 40.
} 
persons, even among old collectors, who venture, in all cases, to act wholly on their own judgment. ${ }^{37}$

Monrad was known to have owned a large library and shortly before moving to New Zealand he sold several art books. He certainly owned a copy of Bartsch, as he used his catalogue numbers in the catalogue of his own collection, which was published in The New Zealand Gazette on 16 January $1869 .{ }^{38}$ It is therefore possible that he was also familiar with Maberly's The print collector. Monrad seems eventually to have become confident in his own knowledge and managed to continue purchasing independently, as he later placed his order directly with Lose \& Delbanco until at least $1853 .{ }^{39}$ He was also making purchases in person, having been recorded as a buyer of several items at the estate auction of the painter Christen Købke (1810-1848) in December $1848{ }^{40}$

Besides acting as an intermediary on Monrad's behalf in the acquisition of prints, Høyen also helped to inform Monrad’s taste. The nationalistic art programme advocated by Høyen, which favoured landscape and genre depictions of typically Danish/Northern life and culture, is reflected in Monrad's collection of paintings, such as Christian Hansen's A section of the arcade at Christiansborg Castle, 1826 (Gothenburg, Sweden: Göteborg Moseum). However, only one work from his print collection can securely be linked to Høyen's nationalist agenda, namely Holger Peter Roed's Bondetinget: a street in Roskilde, ${ }^{41}$ which is an etching after a painting of Rosekilde Cathedral. ${ }^{42}$ The question arises here whether Høyen's influence may also be seen in Monrad's collection of Northern sixteenth-century prints, which did not include a single Danish engraver. The artists included Georg Pencz, Lucas van Leyden, Hendrick Goltzius, Albrecht Dürer, Lucas Cranach the Elder, Hieronymus Cock, Paulus Bril, Jakob Binck, Hans Sebald Beham, Hans Baldung, Albrecht Altdorfer, and Heinrich Aldegrever. Out of this group, only one artist can be directly linked to Denmark: Jacob Binck worked repeatedly in Denmark between the 1530s and the 1550s, and may have been the master of a print from 1535 showing the later king Christian III when duke. ${ }^{43}$ The sixteenthcentury German engravers, however, together with the Flemish artists of the seventeenth century, do make up the largest part of Monrad's collection; despite the

\footnotetext{
37 Joseph Maberly, The print collector: an introduction to the knowledge necessary for forming a collection of ancient prints, London: Saunders and Otley, 1844, p. 55.

${ }^{38}$ See Norman, pp. 118-121.

39 Damsgaard and Jacobsen, p. 40.

40 ibid, p. 32.

${ }^{41}$ Accession number 1869-0001-469.

42 Norman, p. 5.

${ }^{43}$ Bent, p. 675.
} 
current ongoing war between Denmark and the German Confederation, the northern Scandinavian nations nonetheless shared a cultural heritage, which Monrad was able to illustrate by collecting works by Northern European masters.

While the individual works themselves will be discussed in the final chapter, the broad genres of the Northern prints in the collection may be discussed to provide further insight into the contents of Monrad's collection and his motivations for acquiring these specific prints. In Of the Usefulness and Use of Prints, Roger de Piles had advised that everyone should collect those subjects which are in line with their individual taste and profession: 'In short, anything that has relation to our own, whether it be sacred or profane. ${ }^{44}$ In this case, as a bishop, Monrad should be expected to collect religious prints, which, according to de Piles, would 'raise the soul to heaven'. ${ }^{45}$ While indeed 39 out of the 61 Northern Renaissance Monrad prints at Te Papa show biblical subjects, this does not necessarily have to be because of Monrad's personal preference, but could rather reflect the fact that such were the most common subjects of the early engravers. In fact, his print collection covers a wide range of subjects, including mythological, landscape, portraiture, genre, and decorative.

When considering Monrad's entire collection, one realises that landscape and genre make up the largest number of prints, with more than 200 representative works each. These two genres were the ones mostly advocated by Høyen and the Golden Age Painters, and it is possible that landscape prints in particular had a certain power over Monrad's sentiments, as they were reminiscent of his life spent in the beautiful countryside of Denmark. It was during his stay in Vordingborg during the 1820s that Monrad first developed a love for natural beauty and the landscape surrounding him, which he expressed in one of his school essays:

The birch trees were nearly all in leaf and formed a green dome over my head. I left the path and went deeper into the woods until at last I did not know where I was. The sun had already set and a friendly twilight reigned in the forest. The evening star glimmered in the west and the moon shone pensively through the treetops. I was tired and sat down under an old oak. Then I heard the bewitching tones of a nightingale nearby. The scene was so lovely that I could scarcely tear myself away. After I had wandered about in the forest for some time I came down to the

\footnotetext{
${ }^{44}$ Roger de Piles, 'Of the Usefulness and Use of Prints', in The Art of Painting, with the Lives and Characters of above 300 of the Most Eminent Painters, 3rd edition, London: T. Payne and Sons, 1754 [1699], p. 52. ${ }^{45}$ ibid.
} 
lake where the water was quietly lapping the flower decked banks. $^{46}$

Monrad would have been reminded of such settings by prints such as Hieronymus Cock’s (after Matthijs Cock) Landscapes with biblical and mythological scenes: the good Samaritan, 1558 (fig. 2), which also illustrates a scene set at twilight, with paths leading through a thick forest, a peaceful lake, singing birds, several Nordic-looking buildings, including a church, and even a large tree in the foreground resembling an oak. $^{47}$

The contents of Monrad's collection were also partly reliant on his financial means and the contemporary art market. Throughout his collecting activities he had only modest means available, seeing that he never really had a regular income. This would account for the rather poor quality of some of the works. At the beginning of the nineteenth century the art market in general had entered a recession that lasted until the end of the 1840s. Nevertheless, prints were very popular during the 1830s, as they were readily available and the prices were encouragingly low compared with what they had been previously. ${ }^{48}$ Apparently, Northern prints were less in demand at this time than Italian ones, as some collectors did not collect Northern prints at all. The preference for Italian masters was advocated by writers such as John Ruskin and George Cumberland, who wrote in 1827 that 'Neither can the fact be denied that even in the best of the laborious Germans, Albert Durer, we find only a learned pedant, and shall in vain seek for grace, expression, sentiment, or poetic composition. ${ }^{49}$ Therefore German prints in general never fetched anything like as much as Italian ones did. This trend is reflected in the prices which the British Museum paid in 1845: Griffiths notes that German prints averaged a little over $£ 1.10 .0$ each, and Italian ones just under $£ 6 .{ }^{50}$ Only a few years later, during the 1850s, prices began to rise once again and the market had become intense by the 1870s. Thus Monrad was able to take advantage of the current trends even with his limited financial means.

Finally, one should look at the manner in which Monrad stored and organised his collection. In a 1960 letter to P. A. Tomory at the Auckland Art Gallery, Stewart B.

\footnotetext{
${ }^{46}$ Quoted in Petersen, p. 14.

${ }^{47}$ See the appendix for more information on the prints in the collection, including the acquisition date.

${ }^{48}$ Antony Griffiths (ed.), Landmarks in print collecting: connoisseurs and donors at the British Museum since 1753, London: British Museum Press, 1996, pp. 95-96.

${ }^{49}$ Quoted in Howard C. Levis, A descriptive bibliography of the most important books in the English language relating to the art and history of engraving and the collecting of prints, Folkestone: Dawsons, 1974 [1912], p. 48.

${ }^{50}$ Griffiths, 1996, p. 96.
} 
Maclennan (Director of the National Art Gallery) ${ }^{51}$ stated that the Monrad prints had

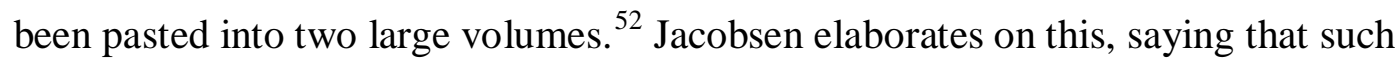
portefeuilles, usually stored with the collector's library, were common at the time. They were large hardcover books with transparent sheets of paper placed over the prints, which in turn were often framed with meticulous ink strokes and marked references to catalogues, such as Bartsch. ${ }^{53}$ Monrad's albums measured approximately 542 x 402 $\mathrm{mm}$, which was big enough to easily accommodate even his largest prints. ${ }^{54}$ It appears, however, that Monrad had compiled these two albums at some time between 1865 and 1869, after he had sold numerous prints at an auction in $1865 .{ }^{55}$ Mathew Norman observed that there were no gaps for possible future acquisitions among the pages, as the 1875 catalogue lists one or more works on each page, which indicates that the collection was considered complete when the prints were pasted into the albums. ${ }^{56}$ How Monrad had stored his collection prior to his departure for New Zealand remains unknown, though it is not unreasonable to assume that albums had already been used then, seeing that he moved around a lot and albums would have been a secure solution when travelling. Even though the albums have by now been broken up, when the collection originally arrived at the National Art Gallery in 1936 the prints were in remarkably good condition. ${ }^{57}$ This can partly be attributed to the care Monrad had taken in their storage, which in turn is a testament to his connoisseur's knowledge of prints and their maintenance.

Prints were originally arranged according to their subjects, but the conventions of the nineteenth century usually classified prints according to schools. This manner was recommended by Maberly, as well as a chronological arrangement, which he believed was a 'more scientific, interesting, natural, and rational mode of arrangement than any

\footnotetext{
${ }^{51}$ While the Colonial Museum, to which Monrad had donated his collection, was not originally intended to house an art collection, the idea of developing a public art gallery in Wellington was starting to develop during the end of the nineteenth century. In 1936, a new building to house the Dominion Museum and new National Art Gallery opened in Buckle Street, Wellington. By the 1980s the National Art Gallery, to which many donations mentioned in this research were made, was running out of room, and on 14 February 1998 Te Papa was opened. For more information, see William McAloon (ed.), Art at Te Papa, Wellington: Te Papa Press, 2009.

52 MU000008, box 4, item 1 - Monrad Collection of Engravings, 1956-60.

53 Damsgaard and Jacobsen, p. 37.

${ }^{54}$ Norman, p. 80.

55 This auction was held in October 1865; it was probably part of a scheme to raise money for the cost of moving to New Zealand, and to depose of personal possessions which the family was unable to accommodate on their journey. The auction numbers from 1162 to 1289 were taken up by a large collection of graphic works, including entire albums and books with original prints. See Damsgaard and Jacobsen, p. 69.

${ }^{56}$ Norman, p. 84.

${ }^{57}$ MU000008, box 4, item 1 - Monrad Collection of Engravings, 1956-60.
} 
other' ${ }^{58}$ Yet Monrad did not apply either of those two systems. Instead he organised his collection using a mostly alphabetical structure. ${ }^{59}$ While writers like Bartsch and the earlier Carl Heinrich von Heineken certainly used an alphabetical framework as well, one should remember that the artists there were only listed alphabetically after first having been categorised under their appropriate schools. Monrad's approach thus resembles mostly the classification of Joseph Strutt's A biographical dictionary (1785), which discusses engravers in alphabetical order without regard for their schools. Monrad still used Bartsch’s monumental work as a guideline, however, seeing that he generally used Bartsch's catalogue numbers to identify works within each artist's oeuvre, and subsequently arranged them broadly according to his sequence and categories. ${ }^{60}$ Monrad did feel comfortable enough to adjust Bartsch’s numerical order occasionally, in order to suit the specific contents of his own collection ${ }^{61}$, which demonstrates his increased confidence in his own judgement as a collector, and his sense for balance and order, which after all were qualities he had always fought for in his own life.

\section{Sir John Ilott (1884-1973) and his Collection}

even greater value lies in the willingness of the donor to share with the community, during his lifetime, the things of beauty which are so dear to his heart. ${ }^{62}$

John Moody Albert Ilott was born at Te Aroha on 12 August 1884. In 1891 his family moved to Wellington, where by 1915 his father had established a limited company specialising in advertising: J. Ilott Ltd. After completing his education Ilott immediately went to work at his father's company in 1902; by 1917 he had become chief executive and regularly undertook longer journeys abroad in order to help the business by extending the Ilott network, especially in Britain, so that the British corporates might trust him with their New Zealand bookings. ${ }^{63}$ He was not just a successful businessman though; having grown up as a devout Christian with a philanthropist father, it is not surprising to learn that Ilott himself became a renowned philanthropist. His son Jack Ilott recalled that 'He was personally concerned for the

\footnotetext{
${ }^{58}$ Maberly, p. 25.

${ }^{59}$ Norman, p. 80.

60 ibid, pp. 81-82.

${ }^{61}$ See Norman pp. 81-83 on how Monrad appropriated Bartsch's numerical sequence of Rembrandt's works .

62 'Doubly precious when shared', Evening Post, Wellington, 18.06.1973, MS-Papers-1068-15 - Tributes and newspaper clippings.

63 'Sir John Ilott: 2010 Business Hall of Fame', in Stephanie Kane (ed.), The Lampstand, No. 20, 2010, pp.49, 53, http://www.wellington-college.school.nz/CommunityDocs/Stephanie/Collegians/2010\%20Lampstand\% 20Part\%202.pdf, (accessed 6 October 2011), p. 49.
} 
welfare of others and spent countless hours in community service. ${ }^{64}$ In 1954 he was knighted by the Queen for his services to the community. ${ }^{65}$ The donation of his print collection to the National Art Gallery seems to fit into this scheme of compassion and charity.

Ilott first donated a collection of 184 prints in 1952, and during subsequent years he made almost annual additions, until his donation had reached more than 700 prints by the time of his death. As with Monrad, one should consider the possible reasons why Ilott chose to part with his beloved collection during his lifetime and in addition to this made a commitment to enriching the National Art Gallery's print collection further by buying more prints for over twenty years. Jack Ilott recalls that the family moved to a smaller house in 1953, and that his father subsequently lacked the space for storing and displaying his prints in his own home anymore. This might have prompted him to turn his previous short-term loans to the Gallery for various exhibitions into a long-term donation, after he had become certain that his collection would be appreciated and well treated there. ${ }^{66}$ Julianne Malpas further suggests that a less heroic motivation might have been Ilott's desire for public acclamation. Upon receiving the news of Ilott's generous intentions in 1952, S. B. Maclennan, the Director of the NAG, wrote to the editor of the Evening Post that 'Mr Ilott is quite frank in expressing his hope that his generosity will be fittingly announced'. ${ }^{67}$ It certainly was 'fittingly announced', and during the subsequent years more grateful articles about Ilott's gifts were published after each donation. Malpas observes that 'The importance of these acknowledgements to Ilott is quite clear as he cut out each article and pasted many of them into a series of scrapbooks, along with other newspaper cuttings mentioning his other charitable and sporting achievements. ${ }^{68}$ These albums are now held at the Alexander Turnbull Library.

Ilott himself appears to have indicated another reason for the donation: a sense of national patriotism and the wish to please and educate the public. Before Ilott had

\footnotetext{
64 Jack Ilott, The Ilott Story, Wellington: Mallinson Rendel , 1993, p. 30.

${ }^{65}$ For a more detailed account of Ilott's life, see Jack Ilott's The Ilott Story, Wellington: Mallinson Rendel , 1993; and 'Sir John Ilott: 2010 Business Hall of Fame', in Stephanie Kane (ed.), The Lampstand, No. 20, 2010, pp.49, 53, http://www.wellington-college.school.nz/CommunityDocs/Stephanie/Collegians/2010\%20 Lampstand\%20Part\%202.pdf.

${ }^{66}$ Julianne Malpas, An incurable collector: Sir John Ilott (1884-1973) and his passion for prints, M.A. diss., Wellington: Victoria University of Wellington, 2005, p. 43.

${ }^{67}$ Letter by Maclennan to J. R. Smith, 9 October 1952, MU000009, box 13, item 2 - Ilott Collection, 1950-64.

${ }^{68}$ Malpas, p. 45.
} 
presented his gift to the National Art Gallery, there had not existed a national collection of prints in New Zealand, a fact which Ilott deeply regretted:

It is a great pity that there is no national collection of etchings in New Zealand [...] And yet it would mean much to these Southern lands of ours to have such a source of interest, of pleasure and of instruction as a collection of the masterpieces of etchings and engravings, both ancient and modern. ${ }^{69}$

Though the Monrad collection had been transferred to the National Art Gallery in 1936, it was not officially accessioned until 1952. And while Ilott called it 'the foundation of a fine national collection of etchings', he felt that a mere foundation was not enough to constitute a first-class national collection. ${ }^{70}$ In 1953 an exhibition of the Gift Collections of Monrad, Ilott and Rex Nan Kivell ${ }^{71}$ was held at the National Gallery for one month, but was then extended for another four months due to the high public interest: 'Substantial interest was reflected in Gallery attendances, which reached record figures.' 72 This indicates that Ilott's assumption about New Zealanders' desire for 'such a source of interest, of pleasure and of instruction' was indeed correct.

Jack Ilott wrote that his father 'had the collector's itch for other items as well., ${ }^{73}$ As a young man he built up a first-class collection of U.S. postage stamps, an interest which was revived later in life when he collected Challon Heads (the first stamps issued by New Zealand from 1855 to 1864). He also had a significant book collection with thousands of volumes, focusing on early New Zealand and Polynesian culture, but also including some rare medieval manuscripts. ${ }^{74}$ His daughter Suzanne recalls 'He owned a most beautiful small illuminated Book of the Hours which I loved to look at. ${ }^{75}$ Thus, like Monrad, Ilott had the desire to collect other objects besides prints, but unlike Monrad, his collecting activities already started during his childhood: 'I seem to have collected all sorts of objects during a long life - my first adventure in this field was the collection of cigarette cards in the days of my youth. ${ }^{76}$ Therefore Ilott represented the

\footnotetext{
${ }^{69}$ MS-Papers-1068-04 - Addresses.

70 ibid.

${ }^{71}$ Sir Rex Nan Kivell donated his collection of contemporary British wood engravings to the former National Art Gallery in 1951.

72 Letter by Maclennan to the editor of the Evening Post, 31 May 1956, MU000008, box 4, item 1 - Monrad Collection of Engravings, 1956-60.

${ }^{73}$ Ilott, 1993, p. 28.

74 These books were later given to the Alexander Turnbull Library, see Suzanne McKellar, Our Ilott family history, Chorleywood, Hertfordshire: S. McKellar, 2003, p. 60.

75 ibid.

${ }^{76}$ John Ilott, 'The Confessions of an Incurable Collector’, 8 July 1967, MS-Papers-1068-04 - Addresses.
} 
type of collector as discussed by Baekeland, who starts collecting often insignificant objects as a child and matures to collecting art as an adult. ${ }^{77}$

While Ilott certainly had a natural inclination towards collecting, his passion for prints appears to have been influenced once again by a single person: Harold Wright. It was during one of his business trips to Britain that Ilott first met Wright, a moment which Jack Ilott recognised as the birth of his print collection: 'He started his collection of etchings and prints in the 1920s when he became friendly with Harold Wright, a senior executive of famous London art dealers Colnaghis. ${ }^{, 78}$ P \& D Colnaghi \& Co. Ltd was the leading art dealer and print publisher at the time, and Harold Wright was their leading print agent, and in 1939 also became a Director at the firm. He became at once both Ilott's 'great friend' and committed print agent. Lady Ilott recalls that John always sought Wright's advice first before making a purchase. ${ }^{79}$ The close bonds with Wright and Colnaghi's became essential to Ilott's manner of acquisition, particularly in view of his isolated location in New Zealand, where neither many dealers nor art literature was available for a young print collector. As has been mentioned with Monrad, the portable medium of prints was an important factor in setting up a collection in remote places, but this alone did not suffice; establishing a social network was crucial.

Collectors usually have a traditional group mentality and collecting is essentially a communal activity, within which collectors share expertise and contacts. ${ }^{80}$ While Ilott often had the opportunity to purchase items in person during his business trips overseas, for the most part he was in New Zealand and would have to rely on Wright to make purchases and recommend prints to him. As Ilott wrote to Maclennan: 'Mr Harold Wright is on the lookout'. ${ }^{81}$ Ilott also had dealers like Colnaghi's send him catalogues of their current stock, so that he might work through them and decide which prints he still desired. Some of these from the dealers Craddock and Barnard, bearing his annotations, are still held at the Te Papa print room; Ilott would make ticks next to the items he still wanted, and crosses next to those he already had (or alternately he wrote

\footnotetext{
${ }^{77}$ Baekeland, p. 207.

${ }^{78}$ Ilott, 1993, p. 25.

79 Telephone conversation between Lady Hazel Ilott and Ann Calhoun, 16 March 1987, MU000044, box 2, item 6 - Sir John Ilott and his times - queries and responses, 1987.

${ }^{80}$ Christopher Baker, Caroline Elam and Genevieve Warwick (eds.), Collecting prints and drawings in Europe, c. 1500-1750, Burlington: Ashgate, 2003, p. 3.

${ }^{81}$ Letter from Ilott to Maclennan, 14 May 1959, MU000009, box 13, item 2 - Ilott Collection, 1950-64.
} 
'Not at NAG' next to them). ${ }^{82}$ Ilott would also send catalogues of his prints in the Gallery to Colnaghi's, so that they could then send him the ones he still needed, thereby completely relying on the good judgment of Wright and his associates. ${ }^{83}$

Wright was not only important for acquiring prints and establishing regular contact between Ilott and Colnaghi, he further exercised a great deal of influence over the contents of Ilott's collection. Wright advocated a canon of artists that was typical of early twentieth-century Britain, and which was composed of mainly Old Masters and modern British and French representatives of the Etching Revival. The increasing popularity of abstract art was starting to undermine the tradition of the canonical Old Masters, and the engravers of the Etching Revival were praised for upholding that tradition. Therefore Wright advised Ilott and other print collectors to pursue both modern engravers such as Muirhead Bone, David Young Cameron, Frank Short and William Strang (all of which are represented in Ilott's collection), as well as the early engravers, including those of the Northern Renaissance. This would create a visual link between the Old Masters and their modern heirs. There is no doubt that Wright projected these ideas onto Ilott, who remembered that 'the late Mr Harold Wright [... told me .... that in his opinion, prints by outstanding etchers of the present period would improve very substantially and would be in much demand in say twenty years. ${ }^{84}$ Wright was openly opposed to modern abstract art and did not believe that artists like Picasso faced a long future in the business. ${ }^{85}$ Jack Ilott told Ann Calhoun on 28 February 1987 that his father also neither liked nor collected many moderns, as 'He was influenced a great deal by Harold Wright on his choice of British printmakers. ${ }^{86}$

Wright and Colnaghi's further shaped the content of Ilott's collection by occasionally presenting him with gifts. Julianne Malpas explains that this was not unusual, especially during the print market boom in the 1920s, when a large number of print dealers had to compete with one another: 'The gift or discounting of merchandise to customers is a relatively common practice that aims to increase and retain customer

\footnotetext{
${ }^{82}$ Craddock and Barnard, Engravings \& Etchings (Fifteenth to Eighteenth Centuries), no. 119, London, $1969 / 70$.

${ }^{83}$ MU000010, box 5, item 5 - Ilott Collection, 1955-77.

${ }^{84}$ Letter from Ilott to Maclennan, 3 June 1966, MU000009, box 13, item 2 - Ilott Collection, 1950-64.

${ }^{85}$ David Maskill, 'Imperial lines: Harold Wright (1885-1961): printmaking and collecting at the end of empire: the Margaret Manion Lecture 2007', Melbourne Art Journal, (11-12), 2009, pp. 86-103, p. 98.

${ }^{86}$ MU000044, box 2, item 6 - Sir John Ilott and his times - queries and responses, 1987.
} 
clientele. ${ }^{87}$ It was in this manner, for example, that Ilott received Dürer's Crucifixion, 1511, in 1952.

While his private collection of early prints amassed before 1952 mainly reflects such a survey collection as recommended by Wright, after Ilott made the transition from a private to public collector, he had even stronger motives for choosing specific Northern Renaissance works. His new agenda involved a self-imposed curatorial role, where his aim was to fill the gaps within the national collection in order to create an art historical collection. As he wrote to Maclennan in 1961: 'I have endeavoured to secure representative etchings of some of the great etchers, thus filling some of our gaps' ${ }^{88}$ While Monrad's collection included a significant number of Dürer prints, apart from three woodcuts these were all engravings. Thus Ilott purchased six more woodcuts during the 1960s, including the Holy Trinity, 1511 (fig. 3), in order to provide a more comprehensive and instructive representation of his oeuvre. Similarly, Martin Schongauer's The Resurrection of Christ, 1470-1482 (fig. 4), was purchased in 1958. This artist, though a major influence on Dürer's artistic development, had previously not been included in the collection. Consequently, as Malpas observed, Ilott's acquisition of this print 'made it possible for the Gallery's collection to be used instructively to show the evolution of German printmaking' ${ }^{89}$

As was the case with Monrad, Ilott's collecting practices were also limited by his financial means and the changing prices of the print market. Ilott usually set a specific amount of money aside each year for the sole purpose of buying prints for the collection. During the 1920 s and 30s this budget entailed no more than $£ 400$ a year, but by the 1970 s he was forced to extend this to $£ 500$ due to increasing prices. Lady Hazel Ilott recalls that while they were in Britain during the 1920s engravings were not in vogue, and John was thus able to buy them cheaply. ${ }^{90}$ Already at this early stage, though, one can see that the Old Northern Masters were among the most expensive artists. His most expensive print purchase at this time was $£ 60$ for Dürer's The Great Fortune, c. 1501-02 (fig. 5), even though it was a rather late impression. Ilott Advertising was also suffering through the Great Depression of the 1930s, so that Ilott was unable to undertake any major print purchases during this time, and once again

\footnotetext{
${ }^{87}$ Malpas, p. 23.

${ }^{88}$ MU000009, box 13, item 2 - Ilott Collection, 1950-64.

${ }^{89}$ Malpas, p. 53.

90 Telephone conversation between Lady Hazel Ilott and Ann Calhoun, 16 March 1987, MU000044, box 2, item 6 - Sir John Ilott and his times - queries and responses, 1987.
} 
during the 1940s due to the Second World War. From the end of the 1950s he started to complain about the speedy increase in prices. In an address to the Wellington Rotary Club on 21 August 1956 he said: 'The prices of fine pictures, porcelain, etchings and art objects generally are rising spectacularly. Foreign Museums and Art Galleries, and particularly the Swiss and West Germans, are buying on a colossal scale. ${ }^{\text {, }}{ }^{1}$ Later in 1967 he wrote to Maclennan: 'I am also sending a pamphlet from P \& D Colnaghi dealing with their latest Exhibition of Fine Prints. I am passing this on to you as you will be as interested as myself in the way in which prices have risen. ${ }^{92}$

From the late 1960s onwards there was a marked decrease in Ilott's purchases of Northern Renaissance and other Old Master prints, which were the most expensive due to their rarity. This in turn was a direct result of their being permanently removed from the market by institutions like galleries and museums, a wave which had been initiated during the previous century. This trend was not merely restricted to Britain or Europe, but was also affecting the United States, where the print boom of the 1960s and early 1970s accelerated the price of graphics with a ready market to levels which collectors of the 1950s never imagined possible. ${ }^{93}$ Theodore B. Donson explained that 'Dealers and collectors were paying tens of thousands of dollars in the early 1970s for proofs of Dürer engravings and Rembrandt ETCHINGS THAT WOULD HAVE COST A FEW THOUSAND WHEN THEY WERE MUCH MORE COMMON IN THE 1950s. 94 Ilott was undoubtedly caught up in this turmoil: 'I am hoping to bring back another really good Rembrandt together with a Durer, but the rise in prices makes it difficult to acquire nearly as many of the classics as I had hoped. ${ }^{95}$ At times he was forced to wait patiently until a particular print became available and affordable enough for him to seize it, as was the case with Dürer's The Holy Trinity: 'For some time I have been endeavouring to secure Albrecht Durer's “The Holy Trinity” and I am delighted that we are now able to include this in our collection. ${ }^{96}$ However, he still had to pay £115 for the piece from Colnaghi's.

\footnotetext{
${ }^{91}$ MS-Papers-1068-04 - Addresses.

${ }^{92}$ MU000010, box 5, item 5 - Ilott Collection, 1955-77.

93 Theodore B. Donson, Prints and the print market: a handbook for buyers, collectors, and connoisseurs, New York: Thomas Y. Crowell, 1977, p. 338.

94 ibid, p. 354.

${ }^{95}$ Letter from Ilott to Maclennan, 18 July 1961, MU000009, box 13, item 2 - Ilott Collection, 1950-64.

${ }^{96}$ MU000009, box 13, item 2 - Ilott Collection, 1950-64.
} 
In 1952 Maclennan claimed that Ilott indeed was a true connoisseur: 'No one is better qualified than the connoisseur who purchases on his own responsibility and on his own behalf. The J.M.A. Ilott Collection was acquired in this way. ${ }^{97}$ Yet, it has been suggested that Ilott was not a true print connoisseur, seeing that he never attempted to assemble an artist's entire oeuvre, and judging from the quality of prints in his collection was not very concerned about states and impressions. ${ }^{98}$ However, as we have seen, the reason why he followed the selective approach praised by Maberly's handbook and other writers of the nineteenth and twentieth century, instead of attempting to collect a single artist's oeuvre, was the fact that he was endeavouring to illustrate an instructive history of engraving and its development. Secondly, the uneven quality of the prints in his collection was not a result of his apparent lack of concern or awareness for early states and fine impressions, but rather of the limited financial means available to him. Whenever he was lucky enough to get the opportunity to acquire a good print with a respectable provenance, he grasped it and was afterwards extremely proud. For example, after having purchased Rembrandt's Jan Lutma, the Elder Goldsmith (1656) in 1964 he wrote to Maclennan:

Rembrandt prints in such superb condition [...] are particularly difficult to obtain. The "Jan Lutma" is an exceptionally fine impression and originally came from the Richard Gutekunst collection - one of the finest collections of Rembrandts previous to the 1914 War. $^{99}$

He also gave numerous speeches on prints for the Wellington Rotary Club, as he was publicly recognised as an authority on this subject. ${ }^{100}$ In these talks he explained the various engraving techniques in great depth, considering the different processes (dry and wet), and explaining about acid baths and inking. He also frequently discussed the qualities that make up a good engraving, and highlighted the importance of quality over quantity. This suggests that Ilott indeed possessed a certain connoisseurial knowledge, as advocated by his friend Wright, who also gave numerous talks like this to various societies all over the United Kingdom.

Further evidence of this, as has been the case also with Monrad, can be seen in Ilott's manner of storing his collection. As previously mentioned, Monrad stored his

\footnotetext{
97 'Ilott Collection of Prints Presented to Gallery', Evening Post, 9 October 1952, MU000003, box 5, item 11 - Gifts.

${ }^{98}$ Malpas, p. 13.

${ }^{99}$ Letter to MacLenna, 13 January 1966, MU000010, box 5, item 5 - Ilott Collection, 1955-77.

100 'Lure of Etchings', Dominion, 24 June 1931, MS-Papers-1068-16 - Newspaper clippings.
} 
prints in two albums: 'It is a really comfortable home with my books, portfolios and etchings arranged and it is a joy indeed to browse through the latter ... dear faithful friends. ${ }^{101}$ In this manner he was once again following Maberly's advice, who talked about the accessibility and intimacy of such albums:

To enjoy a gallery of painting, or statuary, we must walk about it, and we must have daylight; but a portfolio of prints may be laid on the table, and give variety to the amusement of a winter's night, when variety of occupation is most in requisition, and all the circle, as they sit, may participate in the enjoyment. ${ }^{102}$

Ilott's daughter Suzanne recounts that his collection was similarly stored in a private comfortable room, but instead of portfolios he used solander boxes for storage: 'My father had a little room lined with books [...] He kept his etchings in the same small room in special boxes. ${ }^{103}$ Solander boxes were invented by the Swedish naturalist Daniel Carlsson Solander (1733-1782) during the first Cook voyage, as a means to preserve his botanical specimens and manuscripts. ${ }^{104}$

These cases proved efficient in protecting prints from moisture and damp, and had thus been adopted as the typical manner of storing prints at museums by the time Ilott had started his own collection, and are still in use at Te Papa today. Ilott's prints were all hinged at two corners to uniform mounts made out of white cardboard of exactly the same size, which had both practical and aesthetic reasons. ${ }^{105}$ Only two corners were attached to the mount as this prevented damage from pasting them down flat. He was very methodical, as the solander boxes were all numbered, as were the prints inside. ${ }^{106}$ Ilott also wrote systematic index cards for most of his acquisitions between 1921 and 1969, which usually provide the date or year when purchased, source (Colnaghi, Sothebys, Christies, Fine Arts Society, Craddock \& Barnard, Murray Fuller), price and duty paid, references to texts and quotes from these, and charging value of the prints according to a variety of sources. The index card for Albrecht Dürer's The Virgin and Child on the crescent with a diadem, 1514, for example, lists five different charging

\footnotetext{
${ }^{101}$ Monrad quoted in Petersen, p. 105.

102 Maberly, pp. 8-9.

103 McKellar, p. 60.

${ }^{104}$ Roy Anthony Rauschenberg, 'Daniel Carl Solander: Naturalist on the "Endeavour”, Transactions of the American Philosophical Society, New Series, 58 (8), 1968,pp. 1-66, p. 43.

${ }^{105}$ Malpas, p. 37.

106 Telephone conversation between Lady Hazel Ilott and Ann Calhoun, 16 March 1987, MU000044, box 2, item 6 - Sir John Ilott and his times - queries and responses, 1987.
} 
values, including $£$ 14.14.0 from Parsons and $£$ 21.10.0 from Colnaghi's. ${ }^{107}$ While solander boxes might not immediately create an inviting atmosphere to place them on a table for viewing as Monrad's portfolios had done, having prints on individual mounts meant that Ilott could even place several of them next to each other at once and compare them with one another. Most importantly though, it meant that he was able to easily frame individual prints in standard-size frames and display them around his home.

Ilott highlighted the importance of physically looking at prints when he explained his practice of regularly displaying various art works from his collection in his Wellington house prior to 1952:

My own practice is to move my prints each week - taking them room to room, two of them coming down and going back into the solander boxes or cabinets and two new ones going back up again in their place. This is very simple - it takes but little time and also gives all the prints in the collection an opportunity of being displayed on walls. [...] The prints should not be stored away and never looked at - they need airing. ${ }^{108}$

He also loved entertaining and socialising, holding numerous dinner parties, at the end of which he 'would get out his collection of etchings and show them to his guests.' 109 According to Lady Ilott, people would sometimes ring the doorbell and ask to see the etchings, which John or herself would then happily show to them. ${ }^{110}$ All of this suggests that Ilott never truly intended to isolate his collection solely for his own individual pleasure. From the very beginning of his collecting activities he demonstrated a need to show off his precious possessions to other people, whether for validation of his connoisseurial eye, the hope of an enlightening discussion or simple generosity might never be known; by donating his collection he simply continued this tradition in a bigger house.

\section{Te Papa and Other Collectors}

Significant gifts and bequests have been added to the collection at different times and by different routes. ${ }^{111}$

\footnotetext{
${ }^{107}$ Ilott Index Cards; note that Colnaghi's price was more expensive, which might have been a factor in Ilott's decision to change his main dealers to Craddock and Barnard during the 1970s, who were much cheaper.

${ }^{108}$ MS-Papers-1068-04 - Addresses.

109 Ilott, 1993, p. 25.

110 Telephone conversation between Lady Hazel Ilott and Ann Calhoun, 16 March 1987, MU000044, box 2, item 6 - Sir John Ilott and his times - queries and responses, 1987.

${ }^{111}$ Museum of New Zealand, Icons ngā taonga: from the collections of the Museum of New Zealand Te Papa Tongarewa, Wellington: Te Papa Press, 2004, p. 64.
} 
No matter what their similarities or differences might have been, the fact remains that Monrad's and Ilott's generous gifts to the Nation now make up one of the most valuable and significant parts of Te Papa's holdings, not only of the Northern Renaissance prints, but the print collection as a whole. Talking about the Monrad and Ilott collections at the National Art Gallery in 1952, the Evening Post wrote that: 'The two collections together make the gallery a Mecca for all lovers of the copperplate processes. ${ }^{112}$ There is no denying that this was certainly the case in 1952, when print lovers from all across the country flocked towards the capital to marvel at the magnificent collection, which was after all a rarity in this part of the world. However, just by looking at the Northern European fifteenth- and sixteenth-century print holdings one can see that other additional bequests and purchases since then have also significantly contributed to today’s collection. These have until now been largely unrecognised, and many of the collectors remain unknown to the art world, thus an attempt will be made here to acknowledge their participation in creating Te Papa's wealthy print collection.

The first collector to be considered has already been introduced elsewhere in this research: Harold Wright. Frederick Baekeland claimed that in the art world, art collectors are most like art dealers, and in fact many dealers are themselves collectors: 'A surprising number of art dealers started as collectors, only to turn into dealers as they began to do more and more trading and selling because collecting was beginning to strain their finances to breaking-point. ${ }^{, 113}$ Even if not in exact terms, this was the case with Wright; not only was he the major print agent at the British Museum, director of Colnaghi's and Ilott's agent and mentor, he was also a collector himself. In a letter to the Australian artist Lionel Lindsay he confirmed his opinion that dealers not only sell but also love (and subsequently often collect) prints: 'Folk will never believe that the true dealer is as much a print lover as any of the great print collectors [...the dealer takes satisfaction in] having been, he hopes, the intermediary between one loving owner of such treasures and the next. ${ }^{, 14}$ While one cannot deny the immense importance he held in establishing Ilott's famous collection, one should not forget the fact that he himself was a proud collector.

\footnotetext{
112 'Ilott Collection of Prints Presented to Gallery', Evening Post, 09.10.1952, MU000003, box 5, item 11 Gifts, 1937-53.

${ }^{113}$ Baekeland, p. 214.

${ }^{114}$ Quoted in Maskill, 2009, pp. 86-103, p. 90.
} 
Harold James Lean Wright was born on 26 April 1885, in Fulham, London, to George Frederick Wright, a carpenter, and Ann Lean. Despite his modest origins, he managed at an early age to join the firm Obach \& Co, which merged with Messrs P.\&D. Colnaghi in 1911, advancing in his career until he was eventually made director of the firm in 1939. During the inter-war years Wright was also the major print agent of the British Museum. ${ }^{115}$ Lionel Lindsay said about Wright’s knowledge of prints: 'That knowledge has been long in acquiring, not museum won, but in daily contact with prints, their coming and going, and built soundly upon the traditions of a great house.' ${ }^{116}$ His knowledge and reputation were internationally recognised by curators and collectors alike, who often sought his advice about particular prints. ${ }^{117}$ In a 1977 lecture the late Dr Ursula Hoff, talking about her early curatorial years, described Wright as a patron saint rather than a dealer, due to his astounding knowledge of and dedication to prints:

White-haired Harold Wright presided over engravings and etchings and could say, at a moment's notice, whether a Rembrandt print resembled a similar impression in the British Museum, was better than one from the same plate in Berlin and could not approach the fine quality of that held in the Albertina. ${ }^{1}$

Presumably it was this type of knowledge and discernment which Wright believed were necessary for being a collector, and which he stimulated in Ilott and others before encouraging them to actively pursue a print collection.

As we have seen with Monrad and Ilott, the other significant factor for becoming a print collector is establishing a social network. Due to his position at Colnaghi's, this was no restriction for Wright. David Maskill describes him as 'a man who was connected in one way or another with almost every major British and American print collector, dealer and printmaker of the inter-war years. ${ }^{119}$ The connections and qualities that made him a successful dealer and agent for others were essentially the same factors which enabled him to become a print collector.

Only two sixteenth-century Northern prints at Te Papa come from his collection (Barthel Beham's A genius on a globe flying above a landscape, 1520, and Albrecht

\footnotetext{
${ }_{115}^{115}$ Maskill, 2009, pp. 86-103, p. 87.

${ }^{116}$ MS-Papers-1068-16 - Newspaper clippings.

${ }^{117}$ Maskill, 2009, p. 87.

${ }^{118}$ Quoted in Maskill, 2009, p. 88.

${ }^{119}$ ibid, p. 87.
} 
Dürer's The life of the Virgin. The Adoration of the Magi, c. 1501-1503), but in total 496 prints were given to the National Art Gallery by Mrs Wright between 1964 and 1965. His entire collection would have been much more extensive; however this contribution was still one of the most significant ones made to New Zealand to date. What persuaded him or his widow to present such a generous gift to the nation? In fact, it was only due to the close friendship between Ilott and Wright that the latter's collection ended up in Wellington. In a 1965 letter to Mr Philips (Secretary at Colnaghi's), the Director of the National Art Gallery S. B. Maclennan wrote: 'We trust this [Wright's gift] will symbolise our long association, particularly through Sir John Ilott, with Colnaghi’s. ${ }^{120}$ While this statement might be slightly vague, Ilott himself made it clear as to why Mrs Wright gave the prints to New Zealand: 'As you know, Lionel Lindsay, Harold Wright and myself were close friends and the gift has come from Harold Wright's widow in consequence. ${ }^{121}$ Additionally, in a letter to Joseph Burke of Melbourne University he wrote:

You will be interested to hear that I have been in touch with Mrs Harold Wright since my arrival [in London], and we are planning to meet in the near future. She has been exceedingly kind and has offered to donate still further prints to our collection in New Zealand. ${ }^{122}$

A great part of the collection was split up between New Zealand and Australia, with many prints being given to Melbourne University in recognition of Wright's friendship with Lionel Lindsay.

Together with Monrad and Ilott, Wright was probably the only collector to donate Northern Renaissance prints to New Zealand who can be called a connoisseur. The other collectors were more likely amateur collectors, and include Mrs Hilda Webb, Dr and Mrs John Hardwick-Smith, F.W. Littlejohn and Sir Arthur Ward. With the exception of the last, each of these collectors only donated one print to the Northern Renaissance print holdings, which suggests that their collecting activities did not venture beyond the occasional purchase of an item which appealed to their aesthetic preferences. While none of them is known as a collector today, some of them stood in the public eye for other reasons. On the occasion of Dr and Mrs John Hardwick-Smith’s

\footnotetext{
${ }^{120}$ Letter from Maclennan to Mr Philips (Secretary at Colnaghi’s), 03.08.1965, MU000010, box 5, item 5 - Ilott Collection, 1955-77.

${ }^{121}$ Letter from Ilott to Maclennan, 22.05.1963, MU000009, box 13, item 2 - Ilott Collection, 1950-64.

${ }^{122}$ Letter from Ilott to J. Burke (University of Melbourne), 22.05.1963, MU000009, box 13, item 2 - Ilott Collection, 1950-64.
} 
wedding, a short article in the Evening Post claimed: 'There was a great deal of interest attached to the wedding of Miss Alison Mary Kemp, [...] and Dr. John E. HardwickSmith, [...] for both families are very well known and have many friends. ${ }^{, 123}$ John Eaton Hardwick-Smith, a Member of the Royal College of Psychiatrists and a Fellow of the Royal Australian and New Zealand College of Psychiatrists, was born in Wellington in 1910. ${ }^{124}$ He established a successful private practice and in his later years worked part-time for Wellington Hospital. He studied medicine and received training in psychotherapy during his time in England (1929-1938), just before he got married to Alison Mary Kemp. As was the case with Ilott, one could assume it was in England that he also generated an interest in prints and may have even purchased Dürer's The Sudarium held by one angel, 1516 (fig. 6), which he and his wife later gave to the National Art Gallery.

Another prominent figure was Sir Arthur Ward (1906-1993). Arthur Hugh Ward was known for his tremendous contribution to New Zealand animal production. ${ }^{125}$ He was born in Spalding, England, on 25 March 1906 and arrived in New Zealand as a humble farmworker in 1926. By 1930 he had become secretary of the largest herd-testing association in the country. He continued to hold higher offices in the field until he was appointed General Manager of the New Zealand Dairy Board in 1954. He became so interested in dairy-cattle breeding that he began to study genetics. Margaret Rowe highlighted the importance of such studies to him by comparing them to his knighthood: 'He was knighted in 1979 but was more thrilled by the honorary DSc conferred on him by Massey University in 1991 - a reflection of his lifelong commitment to learning., ${ }^{126}$ Again similar to Ilott, he was a recognised philanthropist and was a member of various other organisations, including Chancellor of Massey University, and he contributed in many other spheres of society. In 1981 the NZSAP (New Zealand Society of Animal Production - of which he was a founding member) created an award in his honour: 'The

\footnotetext{
123 'Interesting Wedding: Medical Families Hardwick-Smith - Kemp’, Evening Post, Volume CXXVI, Issue 153, 2 December 1938, p. 16, http://paperspast.natlib.govt.nz/cgi-bin/paperspast?a=d\&cl=search\&d=EP19381202.2. 167.6\&srpos=3\&e=-------10--1----0John+HardwickZz-Smith--. ${ }^{124}$ Mark Davis, ‘John Eaton Hardwick-Smith’, Psychiatric Bulletin, 22, 1998, p. 191, http://pb.rcpsych.org/content/22/3/191.full.pdf.

125 'Sir Arthur Ward Award', http://nzsap.org.nz/sap142.html.

${ }^{126}$ Margaret Rowe, 'Ward, Arthur Hugh - Biography', from the Dictionary of New Zealand Biography. Te Ara the Encyclopedia of New Zealand, http://www.teara.govt.nz/en/biographies/5w8/1.
} 
Sir Arthur Ward Award recognises the successful application of research or experience to an aspect of animal production in New Zealand., ${ }^{127}$

Just as is the case with the other collectors mentioned above, we do not know anything about the extent of his collection or his collecting practices; neither when nor where he bought Jan Collaert's Huntings series (fig. 7), which consists of 16 prints, which he bequeathed to the nation in $1990 .{ }^{128}$ One can assume, however, that he acquired them as a bulk purchase, as they are pasted on equally sized sheets of paper, which are bound together at the left-hand side; these pages are numbered at the bottom centre, which indicates that they may originally have been part of a larger collection. Also, each page bears a collector's mark with a crown and the initials B. L. (unidentified by Lugt). Each of these stamps covers both a part of the print and the sheet on which it is attached, which is proof of the fact that the prints had been assembled in this manner by a previous owner, not Ward. Roger de Piles had advocated in his writing that collectors should focus on those works which closely relate to his own life: 'Every particular man may chose those subjects that are most proper for him, that may either refresh his memory or strengthen his judgement, in which he should be directed by the inclination he has for things of his own Gout and profession. ${ }^{129}$ In Ward's case it is possible that it was the subject matter of the series which attracted him, as it closely relates to his career in the dairy industry and animal production. The prints show a variety of different landscapes in which people are hunting numerous animals, or in which animals are fighting amongst themselves.

Other private individuals, though they did not donate any prints to the nation directly, enabled the purchase of further prints by establishing trust funds; thirty-two of the remaining Northern Renaissance prints have been acquired with these means. The earliest funds dedicated to the purchase of art works for the national collection came from the Harold Beauchamp Trust. Sir Harold Beauchamp (1858-1939) had been the director of the Bank of New Zealand for thirty-eight years, and was the father of Katherine Mansfield. The Harold Beauchamp Trust was established in 1933 to administer the original Deed of Trust of 1923, which was when he had given funds from the sale of his house to the nation for the sole purpose of purchasing pictures for the

\footnotetext{
127 'Sir Arthur Ward Award'.

${ }^{128}$ Besides these 16 prints, he donated one other print in 1990, Ecclesiae militantis triumphi sive Deo amabilium martyrum gloriosa pro Christi fide certamina, 1600-1620, by Jan van Haelbeck (1990-0035-2/ 1 - 31). This is the title-page to a series of thirty-one plates representing Christian martyrs under the reigns of several Roman emperors. ${ }^{129}$ de Piles, pp. 51-52.
} 
Dominion Art Gallery. ${ }^{130}$ The Board of Trustees was required to 'procure pictures of the highest artistic quality irrespective of the nationality or place of residence of the painter'. ${ }^{131}$ Prints purchased with these funds included Dürer's The Four Horsemen, 1498, and Michel Wolgemut's The betrayal of Christ, 1491, both acquired in 1971. The latter was an especially significant contribution to the collection, as it had no prints by this master before this date. Other trust funds include the Mary Buick Bequest fund (one print), and the New Zealand Lottery Board fund (two prints). Jack Ilott had also confirmed that the Ilott Trust was to donate $\$ 2,000$ annually to the Prints and Drawings Department at the NAG. ${ }^{132}$

The largest number of prints purchased with a trust fund, however, came from the Ellen Eames Collection fund. The Ellen Harriet Estate Act was passed in 1985, and as had been the case with the Beauchamp Trust, it was only to be used for purchasing art works: 'any amount requested is to cover the purchases of pictures as set out in the terms of the deceased's will. Funds from this bequest cannot be used for other

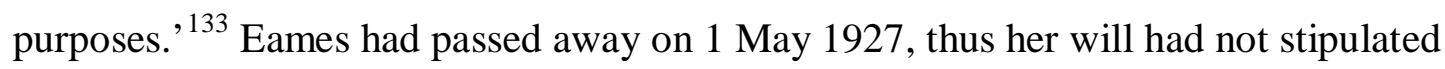
what should happen to her legacy in case the institution to which she had bequeathed the funds were to be replaced, which occurred in 1936 with the opening of the National Art Gallery. This issue was resolved in 1984:

One of the issues raised by this department concerned whether as a matter of interpretation the present Board of the National Art Gallery can be regarded in law as the successor to the Board of Science and Art named in the will. Crown Counsel was satisfied on that point and concluded that the present Board is the proper recipient of funds from the Estate. ${ }^{134}$

Twenty-four Northern sixteenth-century prints now held at Te Papa were purchased due to this decision, including two magnificent series: Heinrich Aldegrever's The Vices and The Virtues (purchased in 1978), and Hendrick Goltzius’ The Passion, 1596-98 (purchased in 1983).

\footnotetext{
130 'Harold Beauchamp Trust Fund', http://collections.tepapa.govt.nz/theme.aspx?irn=630.

131 ibid.

${ }^{132}$ Letter from Anne Kirker to Jack Ilott, 6 April 1984, MU000004, box 23, item 2 - Bequests, Trusts and General Correspondence, 1980-84.

${ }^{133}$ Letter from the Assistant District Public Trustee (D. H. Friis) to the Secretary for Internal Affairs, 4 July 1984, MU000004, box 23, item 2 - Bequests, Trusts and General Correspondence, 1980-84.

${ }^{134}$ Letter from B. C. McLay to the Public Trustee, 11 June 1984, MU000004, box 23, item 2 - Bequests, Trusts and General Correspondence, 1980-84.
} 
The most recent purchases were made by Te Papa itself during the last three years, and include the earliest and one of the latest prints from the collection. In April $2009 \mathrm{Te}$ Papa purchased four pages from the fifteenth-century book Stultifera Navis, or Ship of Fools (1497), and three pages from Hartman Schedel's Liber Chronicarum [Nuremberg Chronicle] from 1493. ${ }^{135}$ These were bought from a leading New Zealand art auctioneer, Dunbar Sloane Ltd, in Wellington, at the antiquarian book auction on 22 April 2009. Te Papa’s Acquisition Proposal relates these items to Acquisition Strategy 07/08, Acquisition Priorities for Art, which consists of 'Historical and contemporary international art that relates to New Zealand or that builds on existing collection strengths' ${ }^{136}$ The proposal further justified the purchase by explaining its significance for the collection:

These examples from two major illustrated publication of the $15^{\text {th }} \mathrm{C}$ would be an important addition to Te Papa's collection. They relate directly to early woodcuts in the collection by Wolgemut and Durer, and would also strengthen our fifteenth and sixteenth-century German engravings - already a significant group, and recently added to with the acquisition of an early etching on iron by Daniel Hopfer [this was also purchased in 2009]. ${ }^{137}$

The latest addition to the collection was An allegory of visual perception (fig. 8), engraved by Jan Saenredam after Hendrick Goltzius, which was purchased from the London-based dealer Christopher Mendez in 2011. Christopher Mendez was established in 1965 and has a first-class reputation for providing prints of fine quality; this impression is indeed very good. The lines are clearly defined and demonstrate the engraver's skill, as the thick and dark lines in the foreground form a marked contrast to the fine and pale lines of the background, creating an illusion of aerial perspective. After Goltzius had returned to Haarlem in 1591 after a year in Italy, he had several engravers working in his studio, among them Saenredam. By 1600 Goltzius had turned mainly to painting and more or less gave up engraving, which marked the end of their collaboration; ${ }^{138}$ this print must date from around this time, as the phoenix's head atop the easel suggests his renewed interest in painting. The exaggerated, elongated and sshaped form of Venus illustrates the adoption of Mannerist ideas in the North towards

\footnotetext{
135 The woodcuts from these books will be discussed in more detail in the next chapter.

${ }^{136}$ Acquisition Proposal 3088 (29-Apr-2009), recommended by Victoria Robson, supported by Tony Mackle, authorised by Lesley Cobb, p. 3. 
the end of the sixteenth century. Te Papa obviously still has an active purchasing policy that recognises these prints as an important part of the museum's collection, which is why it aims at enriching it further whenever possible.

In conclusion, though Monrad and Ilott lived very different lives at very different times, their collecting practices appear to have been quite similar. They both collected in rather remote locations and thus engaged in correspondence with agents and dealers in order to make their purchases. However, Ilott was able to make many acquisitions in person due to his business travels. Both had agents who helped them to form their taste. In Ilott's case he was encouraged by Wright to purchase Old Master as well as modern prints done in emulation of these Old Masters. They both valued good quality prints, though their limited budgets often did not allow them to pursue these. In the end, they donated their respective collections to New Zealand, as they both undoubtedly shared a love for this country and its people. In addition to these great benefactors, there were also a number of other collectors and sponsors whose generous contributions should not only be acknowledged but valued.

The next chapter will closely examine the contents of Te Papa's collection of Northern Renaissance and Mannerist prints itself, in order to illustrates the strengths of the collection and determine whether the creation of an art historically instructive collection was achieved. The quality and physical condition of the prints will also be examined. 


\section{Chapter Three: The Prints}

No matter what their reasons for collecting prints might have been, the fact remains that the combined efforts of these collectors have significantly contributed to the formation of a comprehensive collection of Northern European prints from the fifteenth and sixteenth centuries. Te Papa's collection now includes a great range of German, Flemish and Dutch printmakers. The German school is best represented by three generations of Nuremberg artists: Michel Wolgemut and Wilhelm Pleydenwurff represent printmaking before the sixteenth century, while Dürer illustrates the developments of the early sixteenth century, followed by his successors Hans Baldung, Albrecht Altdorfer, Georg Pencz, Hans Sebald Beham, Barthel Beham, and Heinrich Aldegrever. Dürer's contemporary Lucas van Leyden represents the beginning of the Flemish school, followed by Lambert Suavius, Hieronymus Cock, Cornelis Cort, Philipp Galle, Paulus Bril, Hendrick Goltzius, Jan Saenredam, Crispijn de Passe the Elder, Jan Collaert, and Aegidius Sadeler during the latter part of the sixteenth century. This last group of printmakers made significant contributions to the new landscape genre, as well as encouraging reproductive printmaking in the North. The following is in two sections. The first section gives an overview of the collection's strengths. Section two examines particular prints in more detail.

The collection is particularly rich in Dürer prints; with 43 prints Dürer is the bestrepresented Northern artist of the sixteenth century at Te Papa. There are numerous prints from some of his multi-plate series, both in woodcut and engraving. The Apocalypse, a series of fifteen woodcut illustrations from the Book of Revelation, was published in 1498 and was among the first and best-known projects to bring Dürer international fame. The collection has two prints from this series: The beast with two horns like a lamb and The Four Horsemen (fig. 14). Both are quite good impressions and were acquired by the National Art Gallery during the 1970s, using the financial support from the Ellen Eames and the Harold Beauchamp Collection funds respectively. Another woodcut series, the most extensive of all his series with 37 plates, though at the same time on the smallest scale, was The little Passion from 1511, which is represented in the collection by three plates: Christ before Annas, c. 1508-1509 (fig. 38), and Christ in Emmaus, 1511 (both of which were donated by Sir John Ilott in 1968 and 1964 
respectively), as well as Agony in the garden, 1509-1511, purchased in 1973 with the Mary Buick Bequest trust funds. The latter two have the Latin texts on the verso. Other woodcut series represented in the collection include the Life of the Virgin (Assumption and Coronation of the Virgin, Joachim's offering rejected, The Adoration of the Magi), the Albertina Passion (The martyrdom of the ten thousand, Martyrdom of St. Catherine), and The large Passion (two impressions of Christ in Limbo, Crucifixion, Christ on the Mount of Olives). Te Papa also has three individual woodcuts by Dürer: Samson fighting with the Lion, 1496-1497, St. Jerome in his cell and The Holy Trinity from 1511 (fig. 3). The latter two are fine impressions in good condition, and with a price of $£ 110$ and $£ 115$ respectively they were among the most expensive purchases Ilott made for Dürer's prints and demonstrates the high value he placed on this artist's position in the collection.

Dürer's engraved Passion is also represented at Te Papa, with Christ on the Cross and The Harrowing of Hell, which create a visual response to the earlier woodcut versions in the collection of the same subject from The large Passion. Five Apostles, 1523, is the other engraved series in the collection, which has impressions of Simon and Bartholomew (fig. 47), which Ilott had both bought from Colnaghi's during the 1950s. Together with three portraits, these are among the latest of Dürer's works at the museum; Philipp Melanchthon, 1526, particularly demonstrates his refined and developed engraving technique (note especially the intricate network of fine crosshatching on the face and the reflection of light in the eyes). Te Papa also has five very fine impressions (with very clearly defined lines) of prints showing the Virgin and child, including The Virgin nursing the child, 1519, and The Virgin on the crescent with a sceptre and a starry crown, 1516, which illustrate Dürer's different treatments of the same subject. The other engravings include a variety of different genres, such as religious and allegorical, and include some of his best-known compositions, such as Nemesis (the Great Fortune), c. 1502 (fig. 5), Hercules, c. 1498 (fig. 18), and one of his three master prints, Melencolia I, 1514 (in fact, Te Papa has two different impressions of this print, one having been donated by Monrad, and the other by Ilott in 1959).

The second best-represented artist in the collection is Heinrich Aldegrever (15021555 or 1561) with 22 prints, including examples from his early and late period. The collection boasts the complete series of the Virtues and Vices (1552). These engravings 
were all purchased in 1978 with the Ellen Eames Collection funds, and include some very fine impressions with brilliant contrasts which show off the technical skill of the printmaker. The other engravings include two plates from The story of the first men (The creation of Eve and Adam and Eve at work), and two works from his early period (Ornament with foliage and a vase in the centre, 1528, and Faith, 1528). He originally trained as a goldsmith, which explains the numerous ornamental designs which he produced during this early period, such as the one at Te Papa. Philip Melanchthon, 1540 (fig. 42), engraved after a work by Lucas Cranach the Elder, creates an instructive comparison to Dürer's portrait of the same sitter.

The collection is further enhanced by other print series. It is rich in Lucas van Leyden prints, which include the complete series Christ and the Apostles (1510). Lucas' prints are particularly rare; having a complete series like this, and also in good condition and with fine impressions, is very significant. The other prints by van Leyden include David praying, 1508, SS. Paul and Peter with the Vernicle, 1517, The dentist, 1523 (fig. 29), Cain killing Abel, 1524 (fig. 33), and The fall of man, 1529, all of which came from the Monrad collection. Van Leyden’s style is imitated in Goltzius’ Passion from 1597, nine plates of which were purchased in 1983 to complement the collection. Other substantial print series at Te Papa include the Huntings series by Jan Collaert (16 prints donated by Sir Arthur Ward) and Lambert Suavius’ Christ and the Apostles (13 prints donated by Ilott). Both of these series are in very good condition and are well-printed.

Another strong part of the collection consists of ten prints by the Little Masters Barthel and Sebald Beham and Georg Pencz, complemented by copies of two Sebald Beham prints and three engravings on a similar scale by Albrecht Altdorfer. This group of artists best represents the generation directly succeeding Dürer, and their prints illustrate the influence of this great master as well as of the Italian Renaissance, which was establishing itself further in the North. Barthel Beham's A genius on a globe flying above a landscape, 1520 (which came from Harold Wright's private collection), is a fine example of the small-scale prints produced by these artists, demonstrating their refined skill with the burin. Barthel's brother Sebald is represented by seven prints, including a group of three engravings of satyrs (Satyr playing lyre, Satyr woman playing bagpipe, Satyr sounding a horn), which illustrate the influence of Italian subjects. Despite a few scratches, these are all very fine impressions and in good condition. Two 
copies after Plate 3 and Plate 6 from the series The Peasant's Festival and Twelve Months, 1546-1600, were purchased with the New Zealand Lottery Board funds in 1983. Despite the fact that these were only copies after Sebald's prints, they were deemed worthy enough to be added to the collection and their innovative subject matter is a valuable addition to the oeuvre of the Little Masters.

Eight Flemish landscape prints from the later sixteenth century make up another significant part of the collection. There are four engravings by Aegidius Sadeler, a Mannerist artist famously working at the court of Rudolf II, which were engraved after the designs of Roelandt Savery, Jan Brueghel and Paulus Bril; these prints all came to the collection in the George IV Album. ${ }^{1}$ Monrad's collection was the source of the landscape etchings by Bril (River landscape with a shepherd on a hill to the right, fig. 35) and Hieronymus Cock (The good Samaritan, 1558, fig. 2, Tobit, 1558, Mercury with the head of Argus in his hand, 1558, fig. 34). These etchings are very fine impressions with clear dark lines and illustrate the new-found importance of representing landscape and nature in art.

These examples only demonstrate the prints by the best-represented printmakers in the collection, but there are other significant works by artists such as Lucas Cranach the Elder, Daniel Hopfer, Martin Schongauer and Michel Wolgemut. In order to determine how these works and artists stood in relation to each other, one has to consider the stylistic and technical development of Northern printmaking during the fifteenth and sixteenth centuries. In 1934, during the planning stages for the opening of the National Art Gallery, the Governor-General Lord Bledisloe highlighted the importance of the educational and inspirational nature of a national collection: 'A National Art Gallery [should be] a source of unsullied inspiration to “young students” and indeed to all thoughtful citizens'. ${ }^{2}$ This chapter will therefore examine Te Papa's collection of Northern European prints from the fifteenth and sixteenth centuries in more detail, in order to determine whether such an educational scheme has indeed been achieved and whether the prints actually illustrate the artistic development of German and Flemish printmaking from the early Renaissance to Mannerism. A selection of individual works will be considered, in order to reveal how they illustrate their makers' particular significance within this development. At the official opening of the former

\footnotetext{
${ }^{1}$ King George IV album, 19th century, Royal bindery, England. Purchased 1910. Te Papa.

${ }^{2}$ William McAloon (ed.), Art at Te Papa, Wellington: Te Papa Press, 2009, p. 1.
} 
National Art Gallery (now Te Papa) in 1936, the mayor of Wellington, Thomas Hislop, exclaimed that 'nothing but the best in each respective sphere finds a permanent home within these walls. ${ }^{3}$ It is therefore necessary to examine the prints individually in an attempt to determine their quality (by looking at their states and provenance) and physical condition, which will provide insight into their history and how they have been treated since production. The following presents a small section of the collection in order to illustrate the way in which the prints at Te Papa can be used to demonstrate the artistic development of the Northern print during the fifteenth and sixteenth centuries, as well as an attempt to make a judgement on the collection's overall quality.

\section{The Artists and Their Works: Artistic Development}

[Prints allowed the gallery to] reflect and keep abreast of art movements outside New Zealand in a way that it is not obliged to settle for the second-rate or pale imitation. ${ }^{4}$

The earliest generation of Northern Renaissance printmakers in the collection is represented by Michael Wolgemut (1434-1519), Wilhelm Pleydenwurff (c. 1460-1494) and Martin Schongauer (c. 1448 - 1491). These artists represent the prevailing Gothic style of the latter part of the fifteenth century. Today, Wolgemut is best remembered as the teacher of Albrecht Dürer. However, one should not forget that he was the most important painter, and designer of woodcuts and glass-paintings, in Nuremberg at the end of the fifteenth century. Dürer himself acknowledged his master's wonderful skills when he recommended him as a teacher for his younger brother Hans Dürer in a letter to Willibald Pirckheimer in $1506 .{ }^{5}$ Wolgemut was born in Nuremberg as the son of a painter, Valentin Wolgemut. By 1473 he had become an independent master, having previously worked in the workshop of Hans Pleydenwurff, whose widow he married after Pleydenwurff's death in $1472 .{ }^{6}$ By taking over the workshop, he made Wilhelm Pleydenwurff both his apprentice and stepson. By 1491 Pleydenwurff had become his partner in business. Over the years they collaborated on various projects, including several altarpieces and the repainting of the 'Schöner Brunnen' (fountain) in the Hauptmarkt in $1490 .^{7}$

\footnotetext{
${ }^{3}$ McAloon (ed.), p. 1.

${ }^{4}$ Anne Kirker, quoted in McAloon (ed.), p.14.

${ }^{5}$ Giulia Bartrum, German Renaissance prints, 1490-1550, London: British Museum Press, 1995, p. 17.

${ }^{6}$ Jeffrey Chipps Smith, Nuremberg: a Renaissance city, 1500-1618, Austin: University of Texas Press, 1983, p. 92.

7 ibid.
} 
Their most significant collaboration was on two major publication projects: the Schatzbehalter, 1491 and the Nuremberg Chronicle, 1493, leaves of which were acquired by Te Papa in 1971 and 2009 respectively. The Schatzbehalter (treasure container or shrine of the true riches of salvation and everlasting blessedness) was a collection of devotional and educational texts compiled by Stephan Fridolin (14301498), a local Franciscan friar. ${ }^{8}$ Wolgemut and Pleydnewurff designed ninety-one fullpage woodcuts of biblical and allegorical subjects for it, such as Wolgemut's The betrayal of Christ, 1491 (fig. 9). This particular example is quite a good impression, with a complete border and wide margins. The upper edge of the support is inscribed in letterpress with 'Die Sibenundfunfftzigtist figure' [the $57^{\text {th }}$ figure], while the verso is covered with an extensive German text, which can be seen through the paper on the recto. The illustrations did not necessarily always relate to the accompanying text. This was not unusual and can be linked to the practice of readers buying individual devotional prints with which to illustrate their prayer books. This was not the case, however, in Wolgemut's and Pleydenwurff's most significant collaboration: The Nuremberg Chronicle.

The Nuremberg Chronicle was an illustrated history of the world from creation until 1493, written by the German humanist and Doctor Hartmann Schedel. He was born 13 February 1440, attended the University of Leipzig and later studied medicine and Greek at Padua, which made him one of the earliest Germans to know Greek. ${ }^{9}$ The chronicle is partly an almost unaltered rewriting of the Supplementum Chronicarum by Jacob Philip Foresti of Bergamo, and followed the format of late medieval chronicles, which gave ample space to curiosities of the middle ages, accounts of epidemics, monsters and comets. ${ }^{10}$ Peter Zahn made the claim that 'Schedel's text is scarcely more than an eclectic scholastic work in a thin humanist guise'; instead it is famous for its extraordinary graphic design and woodcuts. ${ }^{11}$

Wolgemut and Pleydenwurff created an unprecedented number of 1809 illustrations, printed from 645 different woodblocks. Publisher Anton Koberger highlighted the importance of the woodcuts in his advertisement for the chronicle:

\footnotetext{
${ }^{8}$ Chipps Smith, p. 93.

${ }^{9}$ Adrian Wilson, The making of the Nuremberg Chronicle, Amsterdam: A. Asher \& Co., 1976, p. 25.

10 ibid, p. 26.

${ }^{11}$ Peter Zahn, 'Introduction', in Adrian Wilson, The making of the Nuremberg Chronicle, Amsterdam: A. Asher \& Co., 1976, pp. 15-29, p. 28.
} 
...nothing like this has hitherto appeared to increase and heighten the delight of men of learning and of everyone who has any education at all....Indeed, I venture to promise you, reader, so great delight in reading it that you will think you are not reading a series of stories, but looking at them with your own eyes. For you will see there not only portraits of emperors, popes, philosophers, poets, and other famous men each shown in the proper dress of his time, but also views of the most famous cities and places throughout Europe... 12

Not only was the number of images unparalleled, but so was their size. The book had a unique paper size made especially for it, which the surviving printing contract describes as 'Superregal'. ${ }^{13}$ Single pages measured 484 x 330 millimetres each, thus the margins of the examples at Te Papa have been only slightly trimmed to 456 x 310 millimetres. Otherwise the three sheets at Te Papa are in remarkably good condition.

The book was an extraordinary feat of design and planning, as the illustrations were not only linked to the text, but they were literally intermingled with it. Usually an image would extend across the page to the same width as the text, yet in the Nuremberg Chronicle the illustrations were let into the text at the inner or outer edges of the page. Even more remarkable is the fact that some branches of the genealogical tables would run right in among the type, which David Bland says had probably never been seen before. ${ }^{14}$ The branch on the right-hand side in Te Papa's Sexta etas mudi, fol. CCLVI (fig. 10)extends all the way to the edge of the sheet, which indicates that this might be one of the branches referred to by Bland and could possibly have extended further along the next page in the chronicle. Secunda etas mundi, fol.XX (fig. 11) demonstrates the way in which plates had been indented into the text at different positions on one page, which must have required a great deal of planning on the part of Wolgemut and Pleydenwurff.

In fact, it is partly this planning which also makes this book an important example of Northern art. It is significant today as its original contract still survives, which provides invaluable insight into the conditions under which the artists were working. From the payment Wolgemut and Pleydenwurff received one can assume that they were

\footnotetext{
${ }^{12}$ Cited in Jeffrey Chipps Smith, p. 94.

${ }^{13}$ Suzanne Karr Schmidt, Altered and Adorned: using Renaissance prints in daily life, The Art Institute of Chicago, New Haven and London: Yale University Press, 2011, p. 40.

${ }^{14}$ Cited in Wilson, p. 55.
} 
treated more as equals rather than a master and his pupil, and either one or both of them were required to always be on hand whenever typesetting or printing was being done, in order to insure that no defects occurred in the blocks. ${ }^{15}$ Additionally, because of the ambitious and lavish nature of the book, the patrons took the innovative step of charging the artists with preparing complete layouts for the illustrations and typesetting of the books; some of these sheets, called 'exemplars', still exist in museums today. ${ }^{16}$

The chronicle was published in Latin on the 12 June 1493, while a German vernacular edition was published on 23 December of that year. It also appeared in both black-and-white and hand-coloured versions, the latter being more expensive. While Te Papa's pages are examples of the former, red gouache has been added to highlight occasional initials throughout the text. Kimberly Nichols links this addition of colour to the tradition of earlier manuscripts:

fifteenth-century relief prints were often hand colored with brush and water-based colorants that included a limited palette of red lead, organic red lakes, and mineral pigments such as yellow ocher and copper greens and blues. The manner in which the color was applied varied from careful shading and modulated toning to a more loose, general application common among early woodcut book illustrations or single-sheet prints. Stencils guided the placement of color and facilitated its repeated application in mass-manufacture. ${ }^{17}$

Such a use of colour is further demonstrated in Te Papa's collection, as one of the illustrations from Sebastian Brant's Stultifera Navis, or Ship of Fools (fig. 12) has been coloured in, most likely by an earlier owner of the book, as it is the only coloured page of the three (which are after all still attached to one another). Demonstrated by Schedel himself, collectors would often colour illustrations in books; and while the colours in this example are very pale and have not been applied with regard to the outlines of shapes in the image, the 'artist' has paid attention as to which colour is being used for which parts. Purple has been used exclusively for the robes of St. Peter and the central figure at the top, while brown and orange/red has been used to contrast with the white of the paper. It is quite rare to find examples where the sheets are still attached to one

\footnotetext{
${ }^{15}$ Wilson, p. 46.

16 ibid, p. 55.

${ }^{17}$ Kimberly Nichols, 'Physical qualities of early prints‘, in Suzanne Karr Schmidt, Altered and Adorned: using Renaissance prints in daily life, The Art Institute of Chicago, New Haven and London: Yale University Press, 2011, pp. 99-105, p. 101.
} 
another, and the Ship of Fools can also be said to be a significant contribution to any collection for representing some of Dürer's earliest commissioned works. ${ }^{18}$ Just like Te Papa's pages from the Nuremberg Chronicle, these pages were also purchased by Te Papa from the Auction House Dunbar Sloane (Wellington) in 2009; this illustrates that the museum still has an active policy for acquiring more examples of Northern prints.

Te Papa’s print by Martin Schongauer (c. 1430-1491) must be considered, as this artist's influence on Dürer is undeniable. He was one of five sons of the goldsmith Caspar Schongauer, who had moved from Augsburg to Colmar, where Martin had established a workshop by 1471. In 1488 he was summoned to Breisach in order to decorate the interior walls of the cathedral with an enormous fresco; he died there in 1491, probably of the plague. He was still working in the Northern Gothic style characterised by stylised flowing drapery and elegant figures with delicate facial types. Though a later work, The Resurrection (fig. 4) still demonstrates these characteristics in the delicate features of Christ and the billowing flag held by the angel on the right. This print was bought by Ilott in 1957 from Colnaghi's and is a fine impression, though the paper has numerous scratches on it.

Between 1466 and 1469 Schongauer was probably apprenticed to the municipal painter of Colmar, Caspar Isenmann, who was to stir Schongauer's interest in Flemish art: 'Like most Upper Rhine painters of his time, Isenmann was greatly influenced by Flemish painting of the preceding generation, especially that of Rogier van der Weyden, and he probably studied in the Netherlands. ${ }^{19}$ Schongauer too was very much influenced by the work of Rogier van der Weyden (1397/1400-1464); later he also made a drawing after van der Weyden's Last Judgement altarpiece in Beaune, Burgundy. ${ }^{20}$ The posture of Christ in Te Papa's The Resurrection of Christ, for example, bears a close resemblance to the risen Christ in the background of van der Weyden's The Miraflores Altarpiece, c. 1442-5 (fig. 13).

Unlike Wolgemut and Pleydenwurff, who produced woodcuts, Schongauer was already working in an engraving technique, which was usually still confined to the

\footnotetext{
${ }^{18}$ While it has been hotly debated whether Dürer had been involved in the making of the Nuremberg Chronicle, there is no doubt that he participated in the creation of the Ship of Fools during his early years. See Anja Grebe, Albrecht Dürer: Künstler, Werk und Zeit, Darmstadt: WBG (Wissenschaftliche Buchgessellschaft), 2006, p. 32. ${ }^{19}$ Alan Shestack, 'Introduction', in Max Lehrs, Martin Schongauer: the complete engravings: a catalogue raisonné, San Francisco: Alan Wofsy Fine Arts, 2005 [1925], pp. 11-17, p. 13.

${ }^{20}$ Bartrum, p. 20.
} 
goldsmiths’ workshops at the time. In fact, his significance as a printmaker lies in the fact that he was the first painter to produce a substantial number of engravings (116). ${ }^{21}$ Engraving offered more expressive potential in draughtsmanship than woodcut, as one could produce extremely fine strokes and crosshatching for modelling and shading. Schongauer realised this potential and unlike earlier engravers, he did not merely use the burin to engrave lines of even width, but he made them taper and swell. The legs of the soldier in the bottom right-hand corner of The Resurrection demonstrate that he could indicate musculature and shadows convincingly by adapting the engraved lines. In 1550, embroiderer Hans Plock of Halle wrote this beneath his impression of Schongauer's Death of the Virgin, c, 1480-81:

This image was judged in my youth to be the finest work of art to have come out of Germany, therefore I pasted it into my Bible, not because of the story which may or may not be true [properly portrayed]. However, since the unsurpassed engraver Dürer of Nuremberg began to make his art, this [estimation of quality] no longer holds. The engraver was called Hübsch Martin ['fine Martin'] on account of his art. ${ }^{22}$

This indicates that already during the sixteenth century Schongauer was recognised as the founder of a German school of engraving only to be superseded by Dürer himself, and that his prints were admired as much for their artistic skill as their subject matter.

Schongauer was also one of the first printmakers to place a mark similar to a goldsmith’s initialled stamp consistently on his works, in his case $M+S$. Dürer continued this use of a monogram and helped to turn it into a traditional sign of authorship, which helped to raise the status of the medium. ${ }^{23}$ This must have been one of his aims when he made the personal decision to make a living primarily by producing prints rather than paintings, and thus attempting to raise the artistic level of woodcut and engraving. ${ }^{24}$ Albrecht Dürer set out to meet Schongauer in Colmar in 1490, but the elder master had died by the time he arrived there. Dürer was able to purchase numerous prints and drawings by Schongauer however, which were to inspire him for years to come. For example, the sky in the Four Horsemen of the Apocalypse (fig. 14) is indebted to Schongauer's large engraving Carrying of the cross (fig. 15), which

\footnotetext{
${ }^{21}$ Bartrum, p. 20.

22 ibid, p. 21.

${ }^{23}$ Karr Schmidt, p. 20.

${ }^{24}$ Bartrum, p. 22.
} 
demonstrated the same subtle graduations of light and a foreboding sky, with the darkness moving along the composition from the left-hand side. ${ }^{25}$ Just like Schongauer, he started experimenting with new effects in intaglio prints early on in his career. In The Prodigal Son amid the Swine, 1496 (fig. 16), he showed the stiffness of the bristles on the animals' backs, and the dry nature of the thatching on the roofs of the farm buildings. In Saint Eustace, 1501, he managed to differentiate between the gleaming hide of a horse and the supple softness of hounds' coats. ${ }^{26}$ These observational skills and ability to create the effects of different textures recalls the animalistic demons in Schonaguer's Tempation of St. Anthony.

Dürer was still also indebted to his teacher Wolgemut and his workshop, where he was an apprentice from 1486 until 1489. There he witnessed and participated in the production of various woodcut illustrations for books such as the Nuremberg Chronicle. These woodcuts were Wolgemut's biggest influence on Dürer, who was inspired by the ambitious and innovative nature of the artists' involvement in the Nuremberg Chronicle. His own publication of the Apocalypse, 1498, became the first book which was both published and designed by the same artist. Te Papa owns two sheets from the book, The beast with two horns like a lamb and The four horsemen, both of which were acquired during the 1970s and are fine impressions; the latter is also from the 1498 German edition, as the verso is inscribed with an extensive German text. The Apocalypse also challenged the traditional relationship between text and image further than Wolgemut and Pleydenwurff had done, thereby fully raising the woodcut to the status of a work of art: the 15 illustrations took up entire pages and were back to back with the text. This meant that these two elements had to be absorbed separately by the reader, each in its own right. ${ }^{27}$ Thus Te Papa's collection effectively illustrates the development of woodcut illustrations from the small scale of the Ship of Fools, to the large and numerous illustrations in the Nuremberg Chronicle, and finally Dürer’s full-page designs which rivalled the text by becoming individual works of art.

When looked at as a whole, Te Papa’s works by Dürer also illustrate his personal stylistic development as well as the changing artistic influences, from Schongauer and

\footnotetext{
${ }^{25}$ Irena Zdanowicz (ed.), Albrecht Dürer in the collection of the National Gallery of Victoria, Melbourne: National Gallery of Victoria, 1994, p. 4.

${ }^{26}$ Museum of Fine Arts, Boston, Albrecht Dürer: Master Printmaker, New York: Hacker Art Books, 1988, p. $\mathrm{xv}$.

${ }^{27}$ Zdanowicz, p. 5.
} 
Wolgemut to the Italian artists of the Renaissance. In both woodcuts and engraving he initially followed the style of Schongauer, which involved broad areas of blank paper to suggest elements such as sky, water, flesh or fabric, as well as strong black outlines. This can be seen, for example, in The Prodigal Son amid the Swine, where the roofs of the buildings create a marked contrast with the empty sky, and the outline of the figure's back is clearly defined against the background. This is the case again in Samson Rending the Lion, where the empty branches of the trees and the birds create wonderful patterns against the white sky and clouds. ${ }^{28}$

After his second trip to Italy between 1505 and 1507, Dürer’s forms became more and more defined in terms of light and shadow modelling volume. ${ }^{29}$ Consequently, outlines are more delicate and have lost their dominant quality, as they are often blended into the shading. This can already be observed in Agony in the Garden from the Small Passion, 1509-1511 (Te Papa's impression has the Latin text on the verso), but it is even more pronounced in The Holy Trinity from 1511 (fig. 3), where the angels appear to vanish into the sky. This woodcut also shows that Dürer started to set fine lines of cross-hatching closer together to indicate darkness and form, such as in the folds of Christ's robes or his torso, rather than increasing the width of lines as in his previous works. The Engraved Passion, 1507-1512 (Christ on the Cross and Harrowing of Hell), also demonstrates a marked darkening of his plates, where figures are only emphasised by a restrained light and the background is sometimes completely filled out. By the time he produced Melencolia I, 1514 (fig. 17), little remained blank in his plates and the brooding winged woman is depicted in silvery greys without any strong contrasts.

Dürer is credited with introducing the Renaissance into the North, thus taking Northern art from the International Gothic style to the classical tradition of Italy. Hercules (fig. 18) is a perfect combination of an Italian pyramidal composition and complex allegorical subject matter, with a highly developed Northern landscape setting described with minute detail. The idealised nudes recall specific works by Andrea Mantegna and Antonio del Pollaiuolo: the woman on the left is a reversed copy of one

\footnotetext{
${ }^{28}$ The original woodblock for this print still exists, and together with Martyrdom of the Ten Thousand and Martyrdom of Saint Catherine, it has been suggested that it might have been cut by Dürer himself (which was very rare indeed, as the artists' designs were usually engraved or cut by an apprentice). See William M. Ivins, Jr., 'Notes on Three Dürer Woodblocks', Metropolitan Museum Studies, 2 (1), 1929, pp. 102-111.

${ }^{29}$ Museum of Fine Arts, Boston, p. xix.
} 
of the figures in Mantegna's Battle of the Sea Gods, 1470s, while the figure of Hercules was clearly inspired by Pollaiuolo’s Battle of the Nudes, 1465-1475. In Nemesis, 15011502 (fig. 5), he was no longer merely adopting figure types of other works, but was using the ideas of the Renaissance to create his own ideal human proportions. The figure was drawn according to a set of proportional ratios developed by Roman theorist Vitruvius, which included for example that the head was one-eighth of the length of the body, and a foot one seventh. Dürer was experimenting with Vitruvian proportions during this time to create the ideal human form. ${ }^{30}$ He also studied Leonardo da Vinci's theoretical writings on the subject and later on wrote his own theory, Art of Measurement. All of these prints demonstrate a definitive departure from the figure types and proportions of Schongauer and Wolgemut.

One final print by Dürer must be mentioned, as it is representative of another important contribution to the development of engraving by this master: Sudarium held by one angel, 1516 (fig. 6). Though Te Papa's impression bears several scratches, it is a very significant print to possess in any print collection, as it is one of only six etchings ever produced by Dürer. The theatrical animation of the scene is heightened by the asymmetrical and upside-down, wind-whipped veil, held by an angel racing through heaven in anguish, surrounded by a remarkable interplay of lines, which was only possible because of this new printmaking technique. ${ }^{31}$ Dürer was one of the pioneers of the art of etching, though he still only used iron instead of copper plates, whose uneven texture meant that it would be bitten with less regularity. ${ }^{32}$ Arthur M. Hind has suggested that the reason for this was probably determined 'by the conventions of an art which was chiefly applied in the armourer's workshop, than from any lack of knowledge of a suitable mordant for copper. ${ }^{33}$ The process of etching, after all, was practised by the goldsmiths, metal-chasers, armourers and gun makers, long before it was used by printmakers. ${ }^{34}$

\footnotetext{
${ }^{30}$ Jeffrey Chipps Smith, p. 102.

${ }^{31}$ Etching was the print medium which came closest to imitating drawing with a pencil, thus artists could produce particularly free and expressive lines.

${ }^{32}$ Arthur M. Hind, A history of engraving and etching: from the 15th century to the year 1914, $3^{\text {rd }}$ edition, New

York: Dover Publications, 1963, p. 80.

33 ibid, p. 106.

${ }^{34}$ ibid, p. 105.
} 
Besides Dürer, Daniel Hopfer was certainly one of the first, if not the earliest, of the German artists to practise etching in our sense of the word. ${ }^{35}$ While he used etching for religious compositions as well, Hopfer still mainly applied it for ornamenting armour and guns, and most of his works were intended as patterns for the goldsmith or sculptor. ${ }^{36}$ Geometric design for an ornamented ceiling (fig. 19) is a fine example of the latter, which once again demonstrates the free, flowing nature of lines produced by etching in the leaves of the design. It is important to remember that especially during the fifteenth and early sixteenth century prints still had various utilitarian purposes and often served as ornament and decoration of various kinds. They were found on playing cards or title-pages; they were used as wallpaper, coats of arms, and (like Hopfer's) as patterns for use by architects, metalworkers and other craftsmen. ${ }^{37}$ Heinrich Aldegrever's Ornament with foliage and a vase in the centre, 1528 is another example of such a print, as is Hans Sebald Behams’s Capital and base of a column, 1543. Therefore Te Papa's collection acknowledges and illustrates some of the different usages of Renaissance prints.

Dürer’s contemporary Lucas Cranach the Elder (1472 - 1553), represented by one print in the collection, not only made invaluable contributions to the print medium, but also to the status of the profession itself. He was unique as a printmaker for the high social rank he achieved. He worked for the Electors of Saxony as court painter at Wittenberg from 1505 to 1547. He was also a town councillor from 1519 to 1545 and held the post of mayor several times between 1537/8 and 1543/4. Tax records of 1528 further show that he was one of the town's two wealthiest citizens. In addition to running a large workshop, Cranach also owned several houses, an apothecary’s shop (with a monopoly on the sale of medicine, herbs and wine), and a publishing firm which specialised in Reformation literature. ${ }^{38}$ The highest honour was bestowed on him by Friedrich the Wise though, whose Saxon coat of arms not only appears prominently on most of Cranach's works, but who also granted the artist his own coat of arms in 1508. This, a winged serpent, subsequently became his signature. Both of these coats of arms

\footnotetext{
${ }^{35}$ Wolfgang Wegner, 'Beiträge zum Graphischen Werk Daniel Hopfers', Zeitschrift für Kunstgeschichte, 20 (3), 1957, pp. 239-259, p. 239.

${ }^{36}$ Hind, A history of engraving and etching: from the 15th century to the year 1914, p. 108.

${ }^{37}$ For more on how prints were used in the Renaissance, see Suzanne Karr Schmidt, Altered and Adorned: using Renaissance prints in daily life, The Art Institute of Chicago, New Haven and London: Yale University Press, 2011.

${ }^{38}$ Bartrum, p. 166.
} 
can be seen in Penance of St John Chrysostom (fig. 20), which Giulia Bartrum observed effectively raised the status of prints to the level of aristocratic sponsorship. ${ }^{39}$

Cranach also exercised a significant influence on the artists of the Danube School, especially with his energetic landscapes from his journey along the River Danube to Austria. The Danube School consisted of a group of artists working around the Danube in Regensburg, Passau and Vienna. Their style became gradually dominated by the representation of nature, which led to the first pure landscape prints. As Giulia Bartrum has stated:

Landscape and atmospheric elements were used to an unprecedented degree to emphasise subject and mood in their compositions. The physical proportions and individual appearance of figures was diminished, and even, in some cases, so reduced in size in comparison with the landscape settings that they are difficult to identify at all. Landscape itself became a subject worthy of representation in its own right for the first time in the history of Western art. ${ }^{40}$

Even though the Penance of St John Chrysostom was produced at court where Cranach’s style became much more elegant, one can still see the importance of the landscape in this print. The figures are completely immersed in it, and masterful highlights sparkle amid the dense foliage. It is a feast of lively burin work and linear patterns throughout. Te Papa's print is a rather weak impression and only has very small margins, nevertheless it was printed on quite white paper and is in very good condition.

One of the leading figures of the Danube School was Albrecht Altdorfer (c. 14801538). Besides Cranach’s work, his landscapes were also influenced by woodcuts, especially those in Peregrinatio in terram sanctam (Mainz, 1486), written by Bernhard von Breydenbach, and the Nuremberg Chronicle, which set precedents both for the representation of landscape views and for the graphic means of realising them. ${ }^{41}$ Altdorfer was also preoccupied with Italian art, which can be seen in the three prints at Te Papa. Seeing that a collection of Italian engravings was recorded in his will, particularly those of Mantegna and Jacopo de’ Barbari, one can presume that he had

\footnotetext{
${ }^{39}$ Bartrum, p. 166.

40 ibid, p. 183.

${ }^{41}$ Charles W. Talbot, 'Altdorfer', Grove Art Online. Oxford Art Online, VUW Lib., http://www.oxfordartonline.com/subscriber/article/grove/art/T002094pg1.
} 
studied their works intensely. ${ }^{42}$ He particularly adopted the style of Marcantonio and one of Te Papa's prints, Venus after the bath, 1520-1526, is in fact made after a work by this Italian engraver. ${ }^{43}$ After 1511 his concern with Italian art stirred an interest in the larger form, which can be seen in his Knight with bread and wine (Melchisedek), 15201526 (fig. 21). ${ }^{44}$ This also illustrates more clearly the architectonic proportions of the Italian figures, reminding one specifically of Mantegna’s St George, c. 1460 (fig. 22).

The last work by Altdorfer at Te Papa is an example of the type of print which links him to the style of 'Little Masters'. Genius with a pair of bellows, 1520-1526 (fig. 23 ) is a very small engraving with dimensions of only $30 \times 25 \mathrm{~mm}$. It should not be surprising to find him working on such a small scale, as his father was a miniaturist and Altdorfer himself had imported the tiny format of Italian nielli to the North. Nielli were small decorative silver plates with incised lines filled with a dark sulphur compound, admired for their delicate nature and complexity of line within a tiny space. ${ }^{45}$ Altdorfer's small prints certainly inspired the 'Little Masters', so called because of the size of their prints, and in fact Sebald Beham's first dated engraving, Portrait of a Young Woman, 1518, is for example essentially just a variation of Altdorfer's Head of a Man, 1507.

The three leading exponents among the 'Little Masters' were Georg Pencz, and the brothers Sebald and Barthel Beham, all of whom are represented in Te Papa's collection. Together with Hans Baldung (by whom Te Papa also has two woodcuts) they are all believed to have been pupils of Dürer, following in his tradition while at the same time feeling the growing influence of Italian art. They have also been dubbed the three 'godless painters', as they were banished from Nuremberg in 1525 for heresy. ${ }^{46}$ The reason for the small format applied by these artists, which was often not bigger than a postage stamp, can be linked to the artists' patrons, educated merchants for example, who might have preferred to collect such images on an intimate scale appropriate for

\footnotetext{
${ }^{42}$ Bartrum, p. 183.

${ }^{43}$ H. R. S., 'The "Little Masters" in the Exhibition of Early German Prints', Museum of Fine Arts Bulletin, 11 (64), 1913, pp. 41-43, p. 43.

${ }^{44}$ Franz Winzinger, Albrecht Altdorfer: Graphik: Holzchnitte, Kupferstiche, Radierungen, München : Piper, 1963, p. 38.

${ }^{45}$ Stephen H. Goddard, 'The origin, use, and heritage of the small engraving in Renaissance Germany', in, Stephen H. Goddard (ed.), The World in miniature: engravings by the German little masters, 1500-1550, Kansas: Spencer Museum of Art, University of Kansas, 1988, pp. 13-29, p. 14.

${ }^{46}$ On 16 January 1525 the three were interrogated at the Rathaus by a committee; for part of the transcript of the hearing see Jeffrey Chipps Smith, p. 32.
} 
private viewing. ${ }^{47}$ Stephen H. Goddard furthermore related their small scale to the rise in popularity of small, portable books (especially octavos), which coincided with the appearance of the first 'Little Master' engravings: 'These engravings, therefore, were small enough to be inserted in letters or interleaved or mounted in even the smallest book without being folded or trimmed. ${ }^{48}$

The 'Little Masters’ represent the generation of artists who came after Dürer, and who were much more influenced by Italian art than their Northern predecessors. Dürer may therefore be seen as an intermediary in the development of Northern engraving: 'Dürer was the catalyst and the bridge between an older generation of artists trained in the Flemish-influenced styles of Martin Schongauer and Michael Wolgemut and younger artists, such as Pencz, who delighted in copying Raphael and Michelangelo. ${ }^{49}$ Pencz, for example, appears to have received instruction in engraving in Venice at the school of Marcantonio Raimondi at one time, and his technique became so similar to the Italian master's one that he has been credited with plates by that artist. ${ }^{50}$ Jeffrey Chipps $^{\circ}$ Smith also links their unprecedented preoccupation with Southern art to the religious tumult of the sixteenth century: 'If Albrecht Dürer and the early humanists had paved the way for artists to understand the lessons of Italian art and culture, the Reformation pushed local artists fully into the Renaissance. ${ }^{51}$ Especially in view of the religious views of these three engravers, it is not surprising to find that most of them turned to portraiture or representative themes drawn from classical literature or daily life in their works.

Hans Sebald Beham produced a prodigious quantity of engravings: approximately 252 engravings, 18 etchings and 1500 woodcuts. Te Papa boasts three exquisite examples of different depictions of satyrs, including Satyr sounding a horn (fig. 24), which has very good contrasts and perfectly illustrates the way in which Sebald adopted classical subject matter and Italian figure types, as the muscular body of the satyr recalls Michelangelo's works and antique sculptures, such as the Belvedere Torso. Arguably, his most significant role lay in the development of a completely new theme for artistic

\footnotetext{
${ }^{47}$ Goddard, p. 13.

48 ibid, p. 18.

${ }^{49}$ Chipps Smith, p. 45.

${ }^{50}$ Leona E. Prasse, 'Engravings by Georg Pencz in the Museum Collection', The Bulletin of the Cleveland Museum of Art, 23 (4), 1936, pp. 50-53, JSTOR, VUW Lib., http://www.jstor.org, p. 51.

${ }^{51}$ Chipps Smith, p. 36.
} 
depiction: peasant festivals. ${ }^{52}$ Peasant festivals came under attack by the new Lutheran religion at the time, thus by creating engravings which showed these festivities, they could still be celebrated and enjoyed in visual form. ${ }^{53}$ The visual vocabulary Beham used was derived from his teacher Dürer, but he expanded this to an unprecedented degree (in both the number of figures and the size of the works). Dürer might have set the scene for peasant imagery, but his artistic production was limited to peasants and to peasant couples, such as The peasant couple at market, 1519 (fig. 25), which also came from Monrad's collection. Even though Te Papa only has copies of two plates from Sebald's The Peasants' Festival and Twelve Months, they still demonstrate the playful nature of these engravings, as one of the men is vomiting during the lively dance. Weather Peasants, 1542 (fig. 26), are similar in subject and demonstrate Sebald's technical ability as well, as he used tiny strokes to indicate the rough fabric of the hats. It has been suggested that these prints are a demonstration of peasant wisdom, as well as a joke, as the one complaining about the weather still holds a pitchfork and has to work his fields before winter, while the other peasant has his hands folded as he has already finished his work. ${ }^{54}$ Te Papa's examples are both trimmed and are very clear and fine impressions.

Shortly after Barthel Beham had returned to Nuremberg after his exile, he moved to Munich in 1527. He later entered the services of Duke Wilhelm IV of Bavaria, who paid for Barthel's journey to Italy, for the sake of 'experience and art', once again a demonstration of engraving's noble patronage and the importance of the Italian influence. ${ }^{55}$ Giulia Bartrum argues that his interest in small, unconventional figure compositions and Italianate designs for secular subjects, including ornament prints with putti, introduced various new aspects to the repertoire of German printmakers. ${ }^{56} \mathrm{Te}$ Papa's print A genius on a globe flying above a landscape, 1520 (fig. 27), is one of eleven engravings Barthel did while only 18 years of age. Though Te Papa's print has been trimmed, it is a fine impression with clear lines and came from the private collection of Harold Wright. Bartrum explaines that this print is a particularly good example of Barthel's technical skill and originality of composition:

\footnotetext{
${ }^{52}$ Alison G. Stewart, Before Bruegel: Sebald Beham and the origins of peasant festival imagery, Hampshire; Burlington: Ashgate, 2008, p. 1.

53 ibid, p. 50.

${ }^{54}$ Goddard (ed.), p. 205.

${ }^{55}$ Bartrum, p. 122.

56 ibid, pp. 122-123.
} 
The idea of the Genius, a spirit of the air who transmitted divine messages to people in the form of premonitions and dreams, was common in antiquity and incorporated into Christian thought during the twelfth century [...]. The connection of the Genius with the concept of luck explains the existence of the globe, which is a common attribute of figures of Fortune [...], as is the walking-stick which Barthel's figure holds. Small winged children or genii with these attributes appear in Dürer's work on the ground [...], but Barthel's innovation is the representation of such a figure in flight as the main subject of a print. The swirling engraved lines he has used to evoke atmosphere and the delicacy of the stippling in the landscape underneath demonstrate his fluent command of the technique. ${ }^{57}$

One should never forget that the label 'Little Masters' only refers to the size of Pencz's and the Behams' prints, and not to any lack of skill or inventiveness, which Te Papa's collection demonstrates was limitless.

Heinrich Aldegrever (1502-1555 or 1561) is also associated with the Nuremberg 'Little Masters' by a stylistic similarity, the enormous popularity of his engravings and by their small format. ${ }^{58}$ Still, his reputation rests largely on his ornamental designs, which make up about one third of his approximately 300 engravings, an example of which has already been mentioned. Te Papa also has a complete set of fourteen prints showing allegorical representations of the Vices and Virtues, which demonstrate the early influences of the Mannerist style in Northern engraving. Aldegrever adopted Mannerist ideas about form during the middle period of his career, as evidenced in the later prints from his engraved series of the Story of Joseph; here the figures are elongated and their heads have become appreciably smaller. ${ }^{59}$ This phenomenon can also be observed in the Vices and Virtues series, for example in the figure of Chastity (fig. 28), whose small head seems to be a complete reversal of the over-sized head of Christ in Schongauer's Resurrection. In addition to this, Chastity shows Aldegrever's new affection for elaborately creased and billowing draperies that appear to have a life of their own, as they move independently from the figure's body. Thus Te Papa's collection clearly illustrates the development of the human form in German engraving

\footnotetext{
${ }^{57}$ Bartrum, p. 123.

${ }^{58}$ Ursula Mielke (compiled by), Heinrich Aldegrever, Rotterdam: Sound \& Vision Interactive, 1998, p. 13.

${ }^{59}$ Rosemarie Bergmann, 'Aldegrever, Heinrich', Grove Art Online. Oxford Art Online, VUW Lib., http://www.oxfordartonline.com/subscriber/article/grove/art/T001636.
} 
from Schongauer's elegant and delicate figures, to Dürer's carefully proportioned ideal forms, to the mannerist figures of Aldegrever.

Dürer’s Dutch contemporary, Lucas van Leyden (1494 - 1533), can also be seen as a transitional figure in the history of engraving, as he reflected both his Gothic heritage and the Renaissance ideas from the South. ${ }^{60}$ He was the first Dutch engraver to be internationally recognised for his work in this medium during his lifetime. Also, none of his Dutch contemporaries produced such a large number of prints as he did; instead artists like Dirk Vellert and Jan Collaert only worked in the medium occasionally. ${ }^{61}$ Like Dürer, he briefly experimented with etching, and is known for being the first artist to etch on a copper plate rather than iron, as well as being the first to combine etching and engraving in a single print. ${ }^{62}$

Representative of his Flemish heritage, Lucas paid great attention to the accurate depiction of reality by presenting objects in minute detail. At the same time, following in the footsteps of earlier artists such as van der Weyden, he demonstrated a remarkable insight into the psychological states of his human subjects. ${ }^{63}$ The dentist, 1523 (fig. 29), is exemplary of the Northern masters' ability to render mood, such as the excruciating pain displayed by this peasant, a quality already praised by the earliest writers such as Vasari and Karel van Mander. The print reminds one once again of the peasant subjects by Dürer, but the realistic depiction of this particular subject contrasts with the former's rather light-hearted portrayals. Te Papa's version is a rather poor impression with numerous scratches and weak broken lines; the bottom right-hand corner has been torn off and reattached, and the writing on the banner has become illegible.

Like Dürer, Lucas was also attempting to perfect his depiction of the human form; apparently the one that satisfied him the most is illustrated in the Apostles series. ${ }^{64}$ In their conception they are very similar to Dürer's series of Five Apostles from 1523, two of which are at Te Papa; however the latter's proportions are already much more classicised. Lucas’ Apostles also establish an informative counterpart to a series of Apostles by another Dutch engraver: Lambert Suavius (c. 1510-1567). Not much is

\footnotetext{
${ }^{60}$ Ellen S. Jacobowitz, and Stephanie Loeb Stepanek, The prints of Lucas van Leyden and his contemporaries, Washington: National Gallery of Art, 1983, p. 7.

${ }^{61}$ Max J. Friedländer, Lucas van Leyden, Leipzig: Klinkhardt \& Biermann, 1925, p. 3.

62 Jacobowitz, et al., p. 23.

${ }^{63}$ ibid, p. 24.

${ }^{64}$ ibid, p. 22.
} 
known about this artist, partly because his work was formerly confused with that of his brother-in-law Lambert Lombard, whose style he followed closely. In technique Suavius was his own master though, as he is known for achieving extremely fine lines and an unusually wide range of chromatic effects in his engravings, achieved from the innovative move of using a glazier's stylus with a diamond point in addition to the traditional engraver's burin. ${ }^{65}$ St. Matthias (fig. 30) is an example of this, with exceptionally fine lines throughout the image and a remarkably subtle tonality. It also demonstrates the new elongated and imposing figure that has replaced Lucas' forms. Yet while the latter's Apostles do not appear restricted in their space, Suavius’ packed compositions makes the figures appear imprisoned in their classical setting of buildings and niches. While the Suavius prints at Te Papa are generally fine impressions and in good condition, Lucas’ Apostles demonstrates a range of different impressions. While the Christ (fig. 31) is a rather poor impression, most likely taken from a worn plate as the lines are very weak and broken, Andrew (fig. 32) and Peter on the other hand demonstrate very clearly defined, dark lines that create wonderful contrasts.

Like most Northern engravers of the sixteenth century, Lucas did not remain untouched by the Italian influence which was sweeping across the Alps. Between 1528 and 1530 Lucas' figure type was dominated by an interest in the nude composed according to Classical ideals of beauty. ${ }^{66}$ Cain killing Abel, 1524 (fig. 33), displays a use of maniera as described in Gian Paolo Lamazzo’s Trattato dell'arte della pittura, scoltura et architettura (1584): 'The painter should combine ... pyramidal form with the Serpentinata, like the twisting of a live snake in motion, which is also the form of a waving flame’. ${ }^{67}$ Lucas' heroic nudes, recalling the muscular bodies by Michelangelo, are composed in the shape of a pyramid, a High Renaissance canon, with the base at Abel's legs and the peak at Cain's uplifted arm. Abel's body is also an example of the type of twisted serpentine body popular in Italy.

Te Papa's works by the Flemish artists Hieronymus Cock (c. 1510-1570), Paul Bril (c. 1554-1626), and Aegidius Sadeler (c. 1570 - 1629) are superb representations of

\footnotetext{
${ }^{65}$ Suzanne Boorsch and Nadine M. Orenstein, 'The Print in the North: The Age of Albrecht Dürer and Lucas van Leyden’, The Metropolitan Museum of Art Bulletin, New Series, 54 (4), 1997, pp. 1+13-60, p. 57.

66 J. P. Filedt Kok, 'Lucas van Leyden', Grove Art Online, Oxford Art Online, VUW Lib., http://www.oxfordartonline.com/subscriber/article/grove/art/T052281.

${ }^{67}$ Cited in National Art Gallery, Face to face: a survey of artists' prints, Wellington: National Art Gallery, 1986, p. 28.
} 
landscapes, a new subject for art, as previously advocated by the Danube School. Cock appears to have given up practising as an artist after 1560 and is today remembered mainly for being one of the most important print publishers of Northern Europe at the time. Mercury with the head of Argus in his hand (fig. 34), from the series Landscapes with biblical and mythological scenes, 1558, was made after a design by Cock's elder brother Matthys. This is significant because, as Hans Devisscher and Timothy Riggs observed, Cock was 'a key figure in the transformation of printmaking from an activity of individual artists and craftsmen into an industry based on division of labour (between the artist who invented a composition and the engraver who turned it into a print)' ${ }^{68}$ While such a division had already become commonplace in Italy by 1550, it was still comparatively unusual in the North.

This print truly shows how the main subject of an engraving had shifted from the human storyline, as set out in the title of the work, to the depiction of nature. The figures of Mercury and Argus, though set into the foreground of the composition, can be easily overlooked in this elaborate landscape of mountains, trees, pasture lands, streams and seas. The paler colour of buildings and mountains disappearing into the distance on the right-hand corner further demonstrates Cock’s ability to render atmospheric perspective. This was due to the fact that more than any of his contemporaries, Cock used 'stopping out' in his etchings to vary the weight of his lines. ${ }^{69}$ Thus the etching technique had evolved from Dürer's and Hopfer's first attempts in order to accommodate the characteristics of new subjects such as landscapes. Te Papa's impression is very fine, and it is interesting to see that the upper left-hand side of the recto has been inscribed in pencil with '93', which appears to relate to Monrad's catalogue. $^{70}$

In Paul Bril's River landscape with a shepherd on a hill to the right (fig. 35) the figures are dwarfed even further by the large trees on the left and the hill on the righthand side; they have also been reduced to mere silhouette outlines camouflaged in their surroundings. Bril also travelled to Rome sometime between 1574 and 1582, where his style changed distinctly, as outlined by Nicola Courtright:

\footnotetext{
${ }^{68}$ Hans Devisscher and Timothy Riggs, 'Cock', Grove Art Online. Oxford Art Online, VUW Lib., http://www.oxfordartonline.com/subscriber/article/grove/art/T018357pg3.

69 ibid.

${ }^{70}$ One has to wonder why he chose to write the number on the front of the print in this case, and on another work by Cock, Landscapes with biblical and mythological scenes: the good Samaritan.
} 
The landscapes from his early period derive their vocabulary largely from the Flemish tradition inaugurated by Joachim Patinir and Pieter Bruegel the elder and developed by his own brother. The paintings feature strong contrasts of forms that engender a sense of dramatic motion. Bril juxtaposed precipitous cliffs with chasms or dark, twisting trees grow from rising mounds next to flat, sunlit pastures. The compositions, sharply divided by light and dark strips, recede rapidly into the distance. Around 1605 his style changed to a calmer, classicizing mode, perhaps influenced by Annibale Carracci and Adam Elsheimer. Works from this period have lower horizons and flatter, less abrupt transitions from foreground to background through gently rising diagonals and a more subtle rendition of light. ${ }^{71}$

Therefore Te Papa's print is an example of Bril's earlier works, as demonstrated by the dramatic contrast created by the dark trees on the left and the hill on the opposite side, which creates a triangular-shaped white space of sky between the two elements, emphasised further by the fact that this is a very fine impression with dark black lines.

Aegidius Sadeler (c. 1570 - 1629) was born in Antwerp in around 1570, the son of an art dealer. His uncles were both engravers in that city (Jan and Raphael Sadeler, $1550-$ I600 and c. 1560-1632, respectively). Wooded landscape with figures and goats is an engraving produced at the court of Rudolf II, made after a design by the court painter Roelandt Savery, so Sadeler was following the precedent set by Cock. Few of the original drawings for the designs of Sadeler's engravings from his time at court survive, as the prints were the aim of these collaborations. Therefore, in addition to being the product of a carefully planned collaboration between different artists, these landscape prints are sometimes the sole record of many of these artists' designs. ${ }^{72}$

Sadeler not only engraved designs by artists he worked with at Rudolf II's court, but he also engraved drawings by Dürer which were held in the emperor's collection. These works, including Head of the Twelve-Year-Old Christ, I598 (engraving, $351 \mathrm{x}$ $229 \mathrm{~mm}$, Philadelphia Museum of Art), were part of larger trend in copying and imitating the master, known as the Dürer Renaissance. Dorothy Limouze observes that Emperor Rudolf II was among the most enthusiastic collectors of Dürer and acted as a

\footnotetext{
${ }^{71}$ Nicola Courtright, 'Bril', Grove Art Online. Oxford Art Online, VUW Lib., http://www.oxfordartonline.com/subscriber/article/grove/art/T011341pg2.

72 Dorothy Limouze, 'Aegidius Sadeler, Imperial Printmaker', Philadelphia Museum of Art Bulletin, 85 (362), 1989, pp. 1+3-24, p. 10 .
} 
patron of this movement 'to revive an earlier artistic tradition native to the Holy Roman Empire. ${ }^{73}$ Hendrick Goltzius was to go even further, by adopting the style and technique of Dürer and other engravers for his own inventions.

Hendrick Goltzius (1558 - 1617) assumed his reputation of a 'Proteus of changing shapes' because of his ability to emulate so many different artists' styles, his fame thus resting mainly on his technical skill and virtuosity. ${ }^{74}$ Previous reproductive engravings often differed from the original in terms of technique, but Goltzius' were so close to the masters' styles that they were often mistaken for one of their unknown works. ${ }^{75}$ As Constantijn Huyges had written during the early seventeenth century 'What is characteristic of Albrecht Dürer, Lucas van Leyden and [...] those unparalleled geniuses, he has expressed so keenly in these works as to make one believe that these artists have returned to the world in him. ${ }^{, 76}$ Instead of merely copying works by Dürer or another master, he engraved in the manner of these artists, creating new compositions in their character and style. While Goltzius might have been one of the first to imitate the style and technique of Dürer and his contemporaries, he was certainly not the last. The influence of these Northern Renaissance engravers can be seen throughout Te Papa’s print collection. ${ }^{77}$

Te Papa owns nine plates from his Passion series, which were created during his master years (1590-98). The sheets are in the manner of van Leyden, but compositionally he followed his own concepts and partially portions of Dürer's Passions. The figures of Christ and the henchman in Christ before Pilate (fig. 36) resemble those of Dürer's woodcut version and Christ's head seems to be based on Dürer's Christ before Caiaphas. The composition of The Resurrection, on the other hand, is quite a radical departure from Dürer and van Leyden, as Christ is here ascending diagonally to the picture plane, unobserved by bystanders. Also, in The Bearing of the Cross (fig. 37) Goltzius gives the impression that Christ is in fact leading the procession to Golgotha, as only the part of a hand and a foot near the right margin

\footnotetext{
${ }^{73}$ Limouze, p. 7.

${ }^{74}$ E. K. J. Reznicek, ‘Goltzius, Hendrick’, Grove Art Online. Oxford Art Online, VUW Lib., http://www.oxfordartonline.com/subscriber/article/grove/art/T033104.

${ }^{75}$ Walter L. Strauss (ed.), Hendrick Goltzius, 1558-1617: the complete engravings and woodcuts, New York: Abaris Books, 1977, p. 11.

${ }^{76}$ Bart Cornelis and Jan Piet Filedt Kok, 'The taste for Lucas van Leyden prints', Simiolus: Netherlands Quarterly for the History of Art, 26 (1/2), 1998, pp. 18-86, p. 37.

${ }^{77}$ See especially Te Papa's works of the British twentieth-century engravers Stephen Gooden, Stanley Anderson and Robert Austin.
} 
indicate that the scene actually conforms to the Gospels. Christ before Pilate is also a brilliant demonstration of his technical skill; note in particular the textures of the step and various fabrics of the clothing created by numerous different types of strokes and stippled dots to suggest tone. These effects can be observed particularly well in the Te Papa impressions, as they are all in general fine impressions in good condition.

\section{Quality and Condition}

Every print, admitted into a collection, ought to have three qualifications. It should be, first, an early impression; secondly, a good impression; and, thirdly, in good condition. ${ }^{78}$

The quality of a print is determined by various factors, including how early an impression is, how good the impression is, its provenance and the physical condition of the print itself. All of these elements can only be assessed by looking at the print itself, which can therefore be uncovered like an archaeological site. ${ }^{79}$ Whether an impression is early or late can usually be judged by comparing a print to other states of the design, as well as considering any scratches in the plate and watermarks on the paper. Arthur Mayger Hind defined a state as 'a stage of development in the execution of plate, block or stone which is recorded by one or more impressions. ${ }^{80}$ A later state therefore might differ from an earlier one by including lines or inscriptions that have only been added by the engraver at a later stage. The earliest states are called proofs, which Roger North observed in 1688 were the most sought-after impressions: 'but above all a proof print is most esteemed, which is an impression before the plate is finished, done for the satisfaction of the graver, who perhaps while he is at work will often roll off a sheet to see how the draught proves, that he may mend or alter it if he sees cause. ${ }^{81}$ However, Hind remarks that only very few of such trial states from unfinished plates of the fifteenth and sixteenth century survive, as in those days they would have been entrusted to the waste-paper basket straight away. ${ }^{82}$

Some of the earliest known examples of proof states are by Dürer, such as the unfinished impressions of Hercules and Adam and Eve. These are particularly

\footnotetext{
${ }^{78}$ Maberly, p. 31.

${ }^{79}$ See especially Anthony Griffiths, 'The archaeology of the print', in Christopher Baker, Caroline Elam and Genevieve Warwick (eds.), Collecting prints and drawings in Europe, c. 1500-1750, Burlington: Ashgate, 2003, pp. 9-28.

${ }^{80}$ A. M. Hind, 'Engravings and Their States-I', The Burlington Magazine for Connoisseurs, 15 (73), 1909 , pp. 25-30, p. 25.

${ }^{81}$ Robinson, p. xlii.

${ }^{82}$ Hind, 'Engravings and Their States-I', p. 28.
} 
significant for showing his method of work, which involved engraving the outlines of the whole composition first with the graver or drypoint, and then completing the details with the burin (just as Gooden did during the twentieth century). ${ }^{83}$ While Te Papa might not own such a rare proof, it does have a proof state of Dürer's Christ before Annas, 1508-1509 (fig. 38), from the Little Passion. This impression was taken before the Little Passion was published as a book with Latin verses in 1511. While the composition itself has not been altered after the printing of this impression, the woodblock had already received several cracks by the time of the 1511 edition. As Te Papa's impression only shows two prominent cracks in borderline (bottom left, top left), and not, for example, the one underneath his monogram which can be seen in some other impressions from before 1511 (after which date even more cracks appeared), it is possible that it is quite an early impression indeed. It is also otherwise a very fine impression, with clear dark lines.

Other examples, where the earliness can be determined by looking at scratches or cracks, include Dürer's Crucifixion (fig. 39) from Large Passion, where the fine crack at the bottom, as seen in impressions from just before 1511 and onwards, is missing. The Four Horsemen is from the later 1498 German edition, however it does not have the crack at the bottom left of the border, extending to the foot of Death, as described by Meder in later printings. ${ }^{84}$ Martyrdom of St. Catherine, on the other hand, shows numerous signs of wear, as lines are partly missing, such as the top of the mountain. Hans Sebald Beham's Mask held by two Genii is a second state of the print, as it illustrates the horizontal hatching across the hand of the genii on the left-hand side, which was added later. Despite its small margin, it is otherwise an extremely good impression with brilliant contrasts, clear lines and even inking. Goltzius' St. Jerome in the Desert (fig. 40) is the first of three states: not only is it an extremely good impression with dark clear lines, but it bears the address of the first state (unlike the inscriptions ICVisscher excu. of the second, and W. Coninck et / I Greve excu. of the third state).

The presence of watermarks can also be used to date a print, but unfortunately only a few of Te Papa's prints show watermarks, and many have been attached to a

\footnotetext{
${ }^{83}$ A. M. Hind, 'Engravings and Their States-II. States in actual life', The Burlington Magazine for Connoisseurs, 15 (77), August 1909, pp. 271-273+275-277+280-283+285, p. 271.

${ }^{84}$ Museum of Fine Arts, Boston, p. 43.
} 
support page and the back of the sheet can therefore not be examined. Schongauer's Resurrection bears the watermark of a Gothic P, which indicates that it was printed during his own lifetime. Aldegrever's Philip Melanchthon (after Cranach) has the watermark of a bear, which can be dated to $1534 .{ }^{85}$ However, S. Blair Hedges has pointed out that using watermarks for dating has its limitations: 'For example, databases (Briquet 1907) contain only a small fraction of the different watermarks that were created, which may exceed a million (Schulte 1934), meaning that the chance of finding an exact match - necessary for dating - is low. Second, even if a match is found, the age of the paper may not correspond closely to the age of the print' ${ }^{86}$

Even if a print has been identified as an early impression, its value can still be materially diminished if it is a bad impression or in poor condition. ${ }^{87}$ Already in 1649, Abraham Bosse confirmed that connoisseurs desired only fine and well-preserved impressions: 'Those who are very curious about fine prints insist on the earliest impressions, in which the lines and hatchings are printed very black and distinctly, and the paper itself is very white. ${ }^{88}$ The number of good impressions that could be pulled from a plate depended on a number of factors, including 'the medium selected, the craftsmanship of the artist, the skill and care with which the printer both prepares the matrix for printing (for example, the inking and wiping of a copperplate) and operates the press, and the quality of the paper and press utilized. ${ }^{89}$

Woodblocks, for example, could warp and consequently not be printed evenly. This might have been a contributing factor to the uneven inking in Baldung's St. Catherine (fig. 41). While the ink appears rather weak in the tree on the left and at the bottom right corner, there is too much ink at the top right-hand corner. This excessive ink has created a black spot underneath the eye of St. Catherine, and part of the pattern of her headpiece is completely lost due to the thick lines. There are also two black smudges around the centre of the image; someone appears to have attempted to erase the more central one of them by scratching the colour off the surface of the page,

\footnotetext{
${ }^{85}$ Mielke, p. 249.

${ }^{86}$ S. Blair Hedges, 'A Method for Dating Early Books and Prints Using Image Analysis', Proceedings: Mathematical, Physical and Engineering Sciences , 462 (2076), December 2006, pp. 3555-3573, p. 3556.

${ }^{87} \mathrm{~J}$. Herbert Slater, Engravings and their value: a guide for the print collector, $3^{\text {rd }}$ edition, London: L. Upcott Gill, 1900, p. 37.

${ }^{88}$ Bosse, p. 85, 'Ceux qui sont très Curieux des dites bonnes Stampes, sont estat des premières impressions, qui est lors que les traits ou hachures qui les composent impriment bien noir \& bien net, \& que le fond du papier en est bien blanc.'

${ }^{89}$ Donson, p. 83.
} 
resulting in a white spot. Dürer's Agony in the garden, Small Passion, also demonstrates the result of too heavy inking, as the background underneath the cloud is almost pitch black.

The appearance of weak and uneven inking can also be the result of printing from a worn plate. Lucas van Leyden's copperplates are known to have worn down quickly because of his very fine engraving technique; as a result good and well-preserved impressions were already rare in the seventeenth century. The print dealer William Smith wrote in 1849: 'The works of Lucas van Leyden even when of ordinary quality are exceptionally rare, but when very fine both as to impression and condition they are, to use a French phrase, nearly introuvables. ${ }^{90}$ Andrew (fig. 32) appears to be a very good and early impression, as the lines are very dark and clearly defined (much better than in the one at the British Museum). Similarly, Karel van Mander and Joachim von Sandrart affirmed that Aldegrever's prints were so highly sought after as collectors' items that some impressions were taken 'from plates so worn as to be virtually unrecognisable, yet they were still much prized. It is interesting to note that even today poor impressions are much treasured,. ${ }^{91}$ Philip Melanchthon (fig. 42), for example, is a rather weak impression that lacks definition in the face and in which the monogram on the left is hardly visible anymore.

Examples of good impressions, where the lines are clearly defined and very black, include Dürer's The Virgin nursing the child, 1519, which was also printed on very white paper. Also Joachim's offering rejected (c. 1504), Aldegrever’s Compassion from the Virtues, Suavius' St. Philip, and Cock's The good Samaritan. Examples of poor impressions, where the inking and line work appears patchy or weak, and the plate has been worn down, include Dürer's Samson Fighting the lion and The Adoration of the Magi (c. 1501-1503), as well as van Leyden’s The Dentist.

Ursula Hoff pointed out the value and usefulness of being able to compare impressions of differing quality, with inks of different hues or different paper. ${ }^{92}$ Te Papa has two versions of three of Dürer's engravings: The Large horse (fig.43-44), Christ in limbo (fig. 45-46) from the Large Passion, and Melencolia I. The Large horse from

\footnotetext{
${ }^{90}$ Cornelis and Kok, p. 71.

${ }^{91}$ Mielke, p. 15.

92 Zdanowicz, p. x.
} 
Monrad's collection is a fine impression, though parts (like the weapon) are not as clearly defined. There are also several faded lines which appear to be folding lines (for example over the neck of horse, above the ear next to the column, and the third hoof). The impression from Ilott, on the other hand, has darker and more defined lines on a whiter sheet of paper, resulting in more brilliant contrasts. Monrad's Christ in Limbo has been printed from a worn plate, or it was unevenly inked, as the colour appears faded and lines broken in some areas, while the bottom left-hand corner appears to have lost detail due to too much ink. Ilott's impression also shows broken lines throughout, however the paper is whiter and thus creates better highlights. Ilott's Melencolia I also is much darker than Monrad's one, therefore it appears to have a more silvery hue, whereas the latter looks merely pale in comparison.

An early impression not only contributes to the aesthetic experience of a print; determining whether an impression is early or late is part of establishing a print's provenance, which consists of tracing back the earliest known history of an object. This in turn can serve to confirm an attribution. David Rudd Cycleback defined provenance as such: 'Provenance is where an item came from. Who made it, who were the owners and sellers, who else significant handled it along the way. ${ }^{93}$ Thus, one way to establish provenance was through a collector's mark, which was usually placed on the back of a print, where it would not distract from the composition. The fully-fledged collector's mark appeared during the eighteenth century, as collectors were increasingly concerned to mark their ownership for posterity. ${ }^{94}$ Owning prints with the marks of famous collectors also enhanced one's prestige within a social network, as it was a testament to one's access to renowned acquisitions. ${ }^{95}$ Most of the marks on the Northern prints in Te Papa's collection have been identified by Lugt's Les marques de collections de dessins et d'estampes (1921), and often belong to collectors who became leading authorities on Dürer's work or who were engravers themselves.

Dürer's St. Bartholomew (fig. 47) is of particular interest, as it bears the marks of two different collectors. Firstly it has the collector's mark of Paul Behaim (1592-1637), from Nuremberg, on the verso, which is the earliest mark in the collection. ${ }^{96}$ In addition

\footnotetext{
${ }^{93}$ David Rudd Cycleback, Judging the Authenticity of Prints by the Masters, Lulu.com, 2007, p. 90.

${ }^{94}$ Baker, Elam and Warwick (eds.), p. 5.

95 ibid.

${ }^{96}$ Dürer designed the coat of arms for Michel Behaim, who died in 1511, (see Ivins, William M., Jr., 'Notes on Three Dürer Woodblocks').
} 
to this, it has 'T.D.Barlow' inscribed on it. Sir Thomas Barlow sold his collection of Dürer's entire print oeuvre to the National Gallery of Victoria, but the outstanding quality of his Dürers was recognised long before they came to Melbourne. ${ }^{97}$ Ever since Barlow bought his first Dürer prints in 1904, he was able to benefit from the specialist knowledge and expertise of Campbell Dodgson, Keeper of Prints and Drawings at the British Museum in 1912-1932. Barlow expressed his own knowledge of Dürer by publishing Albert Dürer, His Life and Work: Being a Lecture Delivered to the Print Collectors' Club on November $15^{\text {th }}$, 1922, in 1923, followed by Woodcuts and Engravings by Albert Dürer, 1926. In a speech on 8 September 1966 Ilott recalled that Barlow himself acknowledged the high quality of St. Bartholomew now at Te Papa: '[some of the] Durer's were acquired by me from Sir Thomas before he sold the Collection as a whole. When I used to see him in England he claimed that he had sold me the better ones, and did not know how I had persuaded him to part with them' ${ }^{98}$ It is indeed a very fine impression with a wide tonal range.

Other Dürer prints with collector's marks include Christ on the cross, 1511, which bears the mark of Frederick Koch (1770-1832) on the verso. Friedrich Koch was a painter and engraver himself, born in Boxweiler, Alsace, and who later settled in Mannheim. There he became a merchant and sold most of his works, which is why he is today mostly a forgotten artist. ${ }^{99}$ His prints were very skilled and heavily inspired by Rembrandt, and his collection of prints (sold in 1875) was dominated by Dürer and the German masters, as well as Rembrandt, Waterloo and other seventeenth-century Dutch artists. $^{100}$

Simon from the Five Apostles, 1523, has the mark of David Bernhard Hausmann (1784-1874), as well as that of P. von Baldinger-Seidenberg († 1911). Hausmann spent time in Aix-la-Chapelle as a young man, at a time when many art treasures from churches, convents and galleries were brought there in order to keep them safe from the French armies. The sight of all these beautiful things greatly impressed the young man, and in 1806, during a trip to Paris, he acquired his first print, namely The Dream by

\footnotetext{
${ }^{97}$ Zdanowicz, p. ix.

${ }^{98}$ MU000009, box 13, item 1 - Ilott Collection, 1964-67.

${ }^{99}$ Frits Lugt, Les Marques de Collections de Dessins \& d'Estampes, Fondation Custodia, http://www.marquesdecollections.fr/.

100 ibid.
} 
Dürer. ${ }^{101}$ Dürer became his preferred artist and he followed all the big sales and auctions to attain more of his works. The exceptional collection thus formed served Hausmann in composing his work on watermarks and paper in Dürer's oeuvre: Albrecht Dürer's Kupferstiche, Radirungen, Holzschnitte und Zeichnungen , unter der besonderer Berücksichtigung dazu Verwandten Papiere und deren Wasserzeichen, 1861. ${ }^{102}$

Dürer's The Four Horsemen, and Schongauer's The Resurrection of Christ both show the mark of Siegfried Barden (1854-1917) on the verso. Barden devoted his leisure to the serious study and collection of fine art. The main engravers represented in his collection included Schongauer, Dürer, Rembrandt, Ostade, Goya, Chodowiecki and Menzel. Lugt wrote that this amateur collector always looked for beautiful impressions of prints. ${ }^{103}$ Schongauer's print also came from the Coppenrath collection, 1890. Alfred Coppenrath (1830-1887), bookseller and art dealer, was educated in his hometown of Münster in Westphalia. He acquired a considerable knowledge of art, especially of prints. He initially began collecting the works of Wierix Ridinger and the 'Little Masters’, as well as Dürer, Schongauer, and finally the Dutch and Italian masters. ${ }^{104}$

In 1931 seventy prints from the Monrad collection were photographed and sent to Colnaghi's for an opinion on their value. Colnaghi's print authorities made the following observations about some of the Dürer engravings: St. George is distinctly late and worn; Virgin with Sceptre is good, but closely shaved; Virgin crowned by two Angels is very good, but the paper is in a bad condition and shaved; Witch is very good, but the paper is damaged; Melencholia $I$ is late and cut on the right. ${ }^{105}$ These comments perfectly illustrate how a print's physical condition was just as important as the quality of the impression. The condition of a print can be influenced by various factors, including their use by other artists, their initial production, restoration, and storage.

Just as artists were among the first to collect prints, so they were also among the first to damage them. During his travels in Italy, the connoisseur Pierre-Jean Mariette reported in 1719 that the prints which he had seen there had all been 'destroyed by the

\footnotetext{
${ }^{101}$ Lugt.

102 ibid.

103 ibid.

${ }^{104}$ Ibid.

${ }^{105}$ IA/1/3008/158/172 - Miscellaneous - Etchings and engravings - Bishop Monrad collection.
} 
painters'. ${ }^{106}$ Signs of artists using prints for copying include squared lines drawn on them, indentations, red chalk on the verso, or sometimes they have even been oiled to make them transparent. Such traces of usage are found much more rarely on Northern prints than on Italian ones, which is a clear indication of the different training practices. Crispsijn de Passe the Elder's Christ and the woman of Samaria, c. 1600 (fig. 48), however, is quite damaged and discoloured, with such squared lines on it. The impression itself is quite good, which could suggest that it is an early impression that was immediately used for copying by other artists. Dürer's The large horse also has a drawing of a horse's head on the verso, and Christ before Annas has a chalk design for a foliage ornamentation drawn on the back.

While these sketches have probably been added by a previous owner of the prints, at least they have been restricted to the verso of the sheets. Goltzius' St. Jerome, though a very good early impression, is in quite a poor condition as the recto has been written on several times. This print is generally in a very poor condition, as it is trimmed, the bottom left corner has been cut off just below the image, and several brown stains are visible (particularly at the bottom right). The inscriptions on the image have been written in both pencil and ink, which has partially eaten through the paper. This also happened on one of the pages form the Nuremberg Chronicle, where someone had underlined several lines in the text and written 'Jonas [illegible]' next to a highlighted section on the right; this ink has also created a hole in the paper.

Other remains of pencil or ink are usually a sign of restoration. Antony Griffiths claimed the most obvious signs of restoration include the blue tinge of a bleached print, the flatness of a pressed sheet where ink has been pushed into the paper, or missing lines added in ink. ${ }^{107}$ He further stated that such restorations were directly linked to the taste of the time: 'Changing taste in prints has inevitably affected restoration practices. Thus, the taste for black-and-white in later centuries has led dealers and collectors to ask restorers to remove the original hand-colouring from many surviving fifteenthcentury prints. ${ }^{108}$ Hans Baldung's St. Catherine had a broken borderline, which has been restored with pen and ink, which in turn has subsequently faded to a different tone.

\footnotetext{
${ }^{106}$ Antony Griffiths, 'The archaeology of the print', in Christopher Baker, Caroline Elam and Genevieve Warwick (eds.), pp. 9-27, p. 21.

107 ibid, p. 24.

${ }^{108}$ Griffiths, 'The archaeology of the print', p. 24.
} 
Cock's Tobit has several rips and at the top right-hand side there is also part of the print missing, which has been compensated by drawing the lines in other ink (whose tone and shape do not fit with the original design). There is also a big drop of ink at the top left, maybe by the same or another owner eager to 'fix' the print.

Sometimes the condition of a print was already affected during the production process. Bril's River landscape (fig. 35) has a couple of creases, for example at the top right-hand corner, which were probably created as the sheet of paper was pushed through the printing press, as the engraved lines go over the creases undeterred. If the engraved lines were offset, on the other hand, this would be an indication that the crease had been created at a later stage, maybe due to the print having been kept loosely in a book. Folds along the centre of large prints were caused by the way in which they had to be dried after printing: as the paper had to be thoroughly wetted before being printed, they were afterwards hung over lines to dry, as can be seen in Sadeler's engraving of The Great Hall of the Hradshin Imperial Castle, Prague, 1607 (fig. 49). Philipp Galle’s Christ crucified between two thieves has a slight fold line along the centre, but it's hardly visible on the recto; otherwise the paper is in very good condition, which is very rare for a print of this size (206 x 276mm). ${ }^{109}$ Dürer's The large Passion. Christ in Limbo (from the Monrad donation) has a folding line horizontally along the centre, as well as several cracks in the border, which the Ilott one does not have.

The most significant factor which determines the condition of a print is storage; whether a print has been attached to a wall, placed in a book or a portfolio, can have poignant effects on its physical state. Sabba da Castiglione, in his Ricordi of 1549, claimed that some collectors would ornament their studioli with prints, mentioning especially the works of Dürer and Lucas van Leyden. ${ }^{110}$ Describing the studiolo of the Florentine Matteo Botti in 1584, Raffaello Borghini also observed that certain prints by Dürer were prominently displayed on the wall: 'they formed part of a frieze below the ceiling, flanked by brackets supporting wax models by various good masters., ${ }^{111}$ This meant they were completely exposed. During the eighteenth century glazing became common practice and the print surface could be better protected under a glass cover. However, the acids in the wood of the backboard could destroy the paper from the back

\footnotetext{
${ }^{109}$ Also significant as this was an etching combined with engraving, as first done by Lucas van Leyden.

${ }_{110}$ Michael Bury, 'The Taste for Prints in Italy to c. 1600', Print Quarterly, 2 (1), 1985, pp. 12-26, p. 14.

111 ibid, p. 15.
} 
and result in a pattern of discolouration by wood grain which can sometimes be found on prints. ${ }^{112}$ Dürer's Christ on the Mount of Olives, 1497, has two very distinct and even holes evenly spaced (unlike the wormholes seen throughout) on the border of the lefthand side of the image, which is an indication that the print might have been kept in a portfolio.

The most common approach to storing prints, before the introduction of solander boxes as used by Ilott and museums today, was to use an album, as Monrad had done. A trimmed margin is a strong indication that a print had been kept in an album, as margins of different widths would have created an unkempt and asymmetrical appearance if more than one sheet had been pasted on a single page. Thus they were usually trimmed just outside the platemark or directly next to the engraved border until no margin was left. If it has been trimmed between the platemark and borderline, it is a thread margin. The wider the margin, the better a print can be handled, for then it is the margin which is touched and not the surface of the print itself. ${ }^{113}$ While some collectors took great care to trim their engravings evenly, others were not as vigilant and cut the margins unevenly, as can be seen in Dürer's Christ in Emmaus. 1511, where the margin is very small at the left and much broader at the bottom, or The martyrdom of the ten thousand (fig. 50), where the engraved border has been cut off completely at times.

The easiest and most common way to put a print in an album was to paste it in by the corners, while larger prints sometimes required more glue along the edges. Anthony Griffiths explains that this method had the disadvantage that the wet glue causes the paper to expand, and when it dries it shrinks. 'This sets strains across the backing sheet and print, which cockles and begins to rub against the page lying above it., ${ }^{114}$ Glue stains from such prints are also very common, such as in Melencolia I, where the entire border has been discoloured because of glue. Goltzius' Flagellation of Christ is a very good impression, but here also the paper is slightly discoloured at the edges of top corners, where it must have been pasted down. Te Papa also has an actual album still intact, with a wide range of Northern and Italian prints. The King George IV album was bought by the Dominion Museum in 1910 from Benjamin Hibbard. It is an album with 23 leaves, containing 79 European etchings and engravings, which originally belonged

\footnotetext{
112 Griffiths, 'The archaeology of the print', p. 10.

113 ibid, p. 19.

114 ibid, p. 13.
} 
to Robert Petre, $10^{\text {th }}$ Baron Petre (1763-1809), as can be seen from the bookplate inside the front cover, which bears his motto 'Sans Dieu Rien'. It was brought to New Zealand by his grandson Henry William Petre (1820-1889), who came here as an early colonist in 1842. Works from the album bear the collector's mark of J. Burleigh James (L1425). The Sadeler prints all come from this album, and appear to have been protected by it, as they are all in very good condition and show crisp colour. Therefore storing prints in an album had both negative and positive effects, as the paper could be discoloured due to the glue used for pasting the prints in the album, while it was also protected from light and direct handling.

Sometimes prints which were issued as a series could be bound as such without needing to be trimmed at all. 'Antwerp publishers of the second half of the sixteenth century and early seventeenth century normally issued plates of identical size as sets on standard size sheets of paper, and expected them to be bound up along their left margin. ${ }^{115}$ Jan Collaert's series of The Huntings (16 plates) is still bound with a string at the left-hand margin. Te Papa has all of the 16 plates, except for the frontispiece. This might explain why out of all of them the first one, showing a lion, a bull and wolves fighting in a coloseum-type arena, is the brownest of the lot (as it was the most exposed). All of the other ones are in very good condition and show wonderful contrasts. The plate with hunters and dogs chasing deer shows a brown spot on the bottom right, possibly a result from rust.

In conclusion, when looking at all the works now held at Te Papa, one can indeed see a great range of artists (from Schongauer and Wolgemut, to Dürer, van Leyden and the Little Masters, to Goltzius and the beginning of Mannerism), as well as a range of subjects and techniques (including line engraving, woodcut and etching), which provides a comprehensive representation of Northern European prints from the fifteenth and sixteenth centuries. Many of the artists were masters and apprentices to one another, hence illustrating a clear line of artistic succession and development. Closely examining the prints one by one can provide insight into their history and help to determine their quality. Various scratches or lack thereof can aid in identifying states of impressions and provenance, while their physical condition illustrates whether they have been welltreated and how they have been stored since production. Overall, the quality of Te

${ }^{115}$ Griffiths, 'The archaeology of the print', p. 12. 
Papa's impressions is rather uneven; however, this analysis has demonstrated that the collection has very fine and significant prints indeed. 


\section{Conclusion}

The 164 early Northern European prints discussed in this research make up a strong part of Te Papa’s collection of graphic art. It includes all of the significant printmakers from the late fifteenth century until the end of the sixteenth century, and the museum is still adding to this list by purchasing more prints to complement the existing collection. The artists represented in the collection, and the manner in which the prints have been acquired, follows a tradition of print collecting that has developed over the last 500 years. While prints were collected from very early on, this was usually for utilitarian purposes, such as study in painters' workshops or decoration in prayer books; they were not considered works of art. Even Vasari described printmaking more as a craft than an art, as he praised only the Northern printmakers' technical skill with the burin. Samuel Quicchelberg wrote the first guide for the arrangement of a print collection by a collector in 1565, in which prints are set on an equal footing with painting. However, this ideal print collection is still part of a larger encyclopaedic collection, aiming at creating a microcosm of the world, in which the prints are seen as tools of knowledge and are arranged according to subject in order to provide visual documentation of this microcosm. By the end of the seventeenth century prints were finally separated from other collections and are given a domain of their own, where they are also arranged according to masters (first according to their popularity, and later chronologically), which highlights the individual artists' talents and thus formed the beginning of the art historical approach practised by museums and private collectors today.

Vasari was amongst the first writers to set up a canon of the best printmakers, which included Northern European engravers such as Dürer, van Leyden and Suavius; this canon has persisted until now. Occasionally it had altered slightly, most notably with the exclusion of reproductive engravers, as advocated in Bartsch's writings during the nineteenth century. New printmakers and techniques also had an effect on this canon, by adding new names to the list which either eclipsed the old masters or highlighted their significance further. While Rembrandt for example eagerly collected the works of Lucas van Leyden, his own painterly technique appealed to his contemporary collectors and often overshadowed the sixteenth-century printmakers. 
Twentieth-century woodcutters, on the other hand, demonstrated the expressive qualities of the medium which led to a new-found interest in the German woodcutters from the fifteenth century, such as Wolgemut. With the emergence of a canon, collectors started to focus on particular printmakers and set themselves a goal of collecting their whole work. This approach was aided with the development of the catalogue, such as Bartsch's, which provided collectors with a list of the printmaker's entire oeuvre. However, the choice of the prints which were to become part of a collection became ever more limited over time, as prints became rarer and public institutions (with more efficient means) became active participants in the print market during the nineteenth century. Instead of collecting an artist's entire works, collectors were advised to acquire only a few examples of the best printmakers. The collectors whose donations now make up Te Papa's collection applied such a selective approach during their collecting practices.

These collectors included Bishop Monrad and Sir John Ilott, whose gifts make up more than half of the prints discussed here. Monrad's donation indeed included prints from a range of twelve different printmakers, some of whom were only represented by one print which demonstrated their particular strengths, such as Paulus Bril's landscape. Seeing that Ilott was a New Zealander, whereas Monrad spent only three years here, one can expect to find different reasons for their gifts. Indeed, Monrad is most likely to have donated his print collection as a way of paying off debts he had incurred in New Zealand and in order to express his gratitude for providing a safe haven for his family while his homeland was in turmoil. On the other hand, it has been suggested that Ilott was simply running out of space for storing his prints and was hoping for public acclamation (which cannot have been the case with Monrad, as he would not have been in the country to enjoy it). Ilott was a renowned philanthropist, however, and he wanted to help in building up a praiseworthy national collection of prints. This was also the motivation behind some specific purchases of Northern prints, such as Schongauer's The Resurrection of Christ, as he was attempting to fill the gaps in the collection. Their choice of storage also differed, as Monrad kept his prints in portable albums, whereas Ilott stored them systematically in solander boxes, allowing him to select different ones to display in his house.

While their reasons for donating their prints and their manner of storing them might have been different, their collecting practices were in fact quite similar. They 
were both inspired to start collecting prints by a professional and personal friend, who then became their agent and taste setter. In Monrad's case this was Niels Høyen, who advised him on which artists to purchase and bought prints in Monrad's name in Copenhagen while the latter was in Vestlev-Ulslev. Harold Wright performed similar tasks in London for Ilott, who despite his occasional business trips overseas (during which he could personally undertake print purchases) was still reliant on such connections. Both collectors also frequently ordered auction catalogues from dealers to help them in their purchases. Through the help of their friends and agents, they became confident in their own judgement and formed a connoisseur's knowledge; however, their limited financial means did not always allow them to pursue these, which resulted in the occasionally uneven quality in their print collections.

Monrad and Ilott are certainly the best-known, but not the only private collectors to contribute to Te Papa's holdings of Northern prints from the sixteenth century. Wright himself emerges as a collector, which is not unusual for a dealer; his close friendship with Ilott became the reason why part of his print collection found its way to Te Papa. Other donors included Dr and Mrs John Hardwick-Smith and Sir Arthur Ward, who were public local figures. Ward especially was a recognised philanthropist, just like Ilott, for which he was awarded a knighthood. While these collectors might not have been collecting prints on a large scale, their contributions are nonetheless significant. In addition to this, a large amount of the prints were purchased by the National Art Gallery, using various trust funds, and prints are still being purchased by Te Papa itself, as part of an on-going effort to increase the collection further.

These donations and efforts have resulted in a comprehensive collection of Northern European prints in three different media (woodcut, engraving, etching), which is particularly strong in Dürer prints. The collection illustrates the artistic development of not only this artist, but of the printmaking medium in the North, as well as of specific subjects found in prints. For example, by purchasing several pages from two fifteenthcentury publications in 2009, Te Papa ensured that its collection demonstrates the development of the woodcut and book illustrations from the early small-scale Ship of Fools, to the large Nuremberg Chronicle, ending with Dürer's Apocalypse series, in which the illustrations directly compete with the text of the book. Similarly, various figure series in the collection illustrate the evolution from the elegant Gothic form of the end of the fifteenth century to the classical proportions inspired by the Italian 
Renaissance, to the exaggerated forms of the Mannerists at the end of the sixteenth century. New subjects for art that emerged at this time are also included in the collection, such as the peasant imagery developed by Dürer and his successors the 'Little Masters'. The new landscape genre is represented by a fine group of prints by the Flemish artists Bril, Cock and Sadeler, in which the human storyline has been overshadowed by the impressive landscape views.

Careful examination of the individual prints has revealed that the collection includes both weak and very fine impressions in good condition. Requirements for a good impression include that it is an early impression and well-printed; Dürer's Christ before Annas (fig. 38) is an example at Te Papa which demonstrates both of these requirements. Whether an impression is early or late can be determined by looking at apparent scratches or broken/patchy lines. Some of Te Papa's prints bear watermarks or a collector's mark, which help to further establish a print's provenance. Traces of usage and storage can also be seen within the collection, such as the squared lines, rips and stains on Crispsijn de Passe the Elder's Christ and the woman of Samaria (fig. 48), a clear indication that it had been used for study in a painter's workshop. Overall, Te Papa's collection of fifteenth- and sixteenth-century Northern European prints is very commendable indeed. It includes fine impressions of the most important early printmakers, some works of whom have been discussed here for the first time. The museum is still actively adding to the collection, which will no doubt become even more comprehensive and impressive in future. 


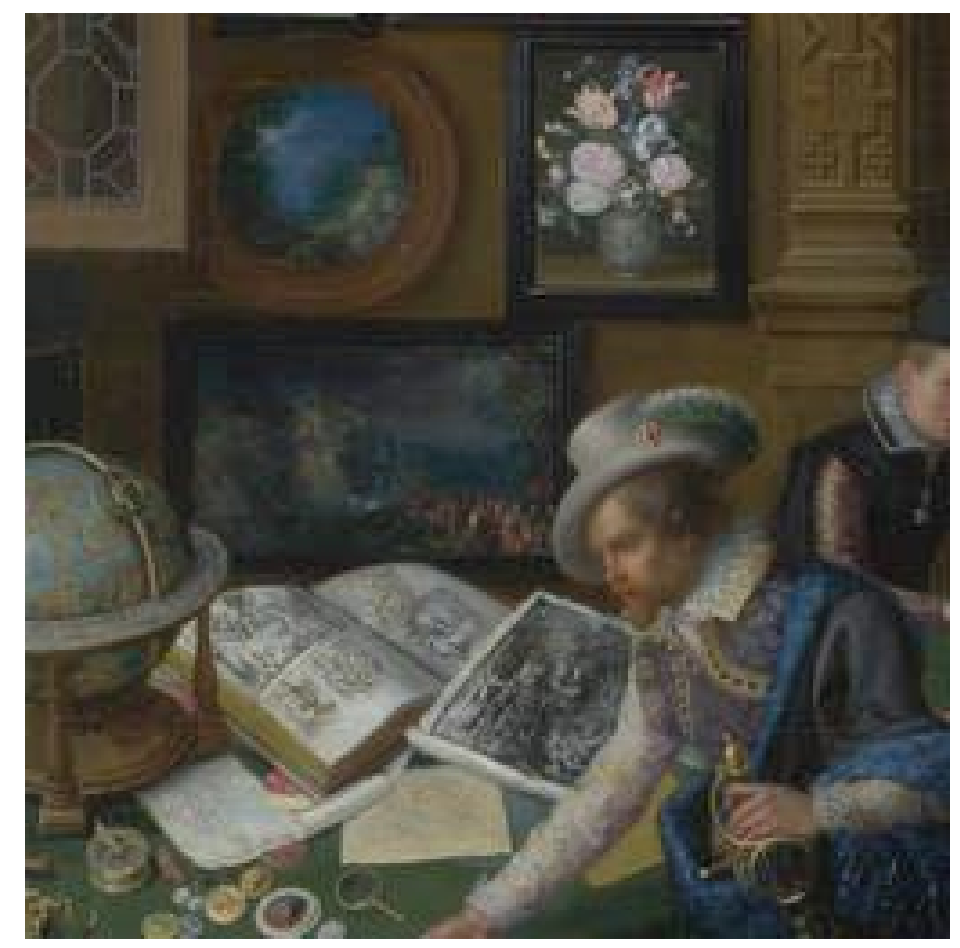

Fig. 1: Unknown (Flemish), Cognoscenti in a Room hung with Pictures, detail, c. 1620, oil on panel, 95.9 x $123.5 \mathrm{~cm}$, National Gallery, London.

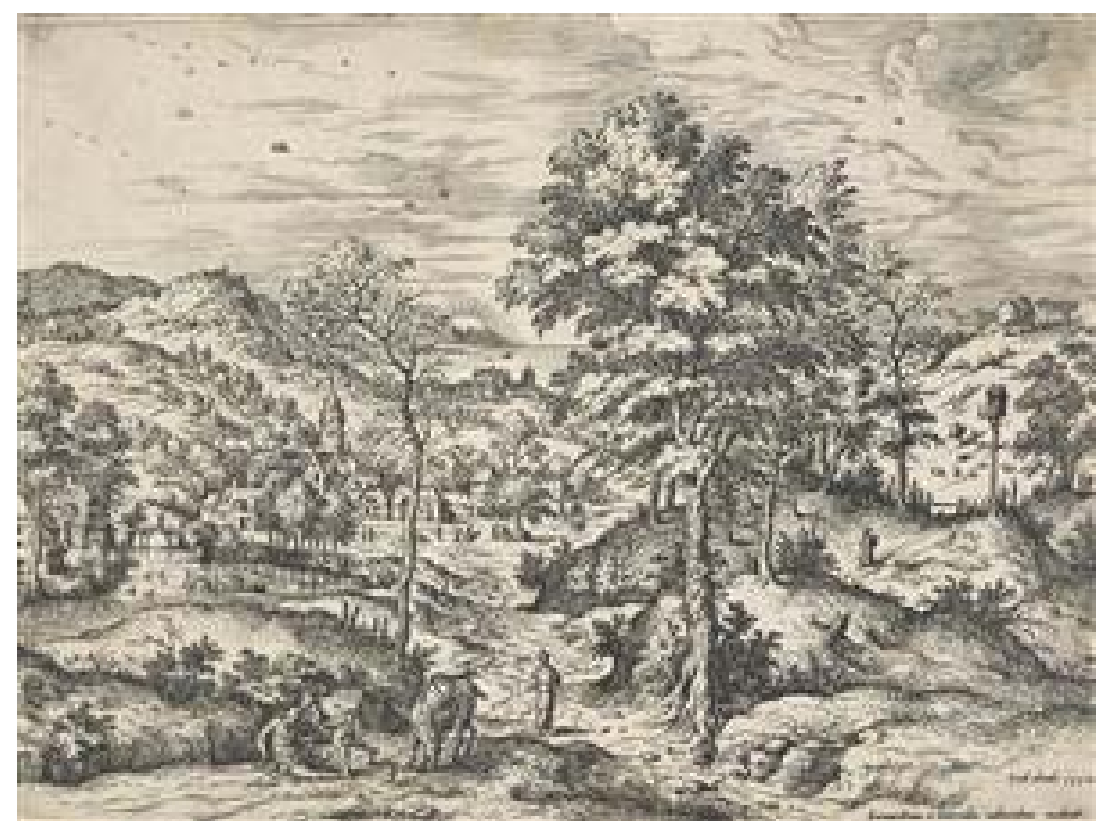

Fig. 2: Hieronymus Cock (after Matthijs Cock), Landscapes with biblical and mythological scenes: the good Samaritan, 1558, etching, 230 x 311 mm (Support 23 x 311 mm), Museum of New Zealand Te Papa Tongarewa, Wellington. 


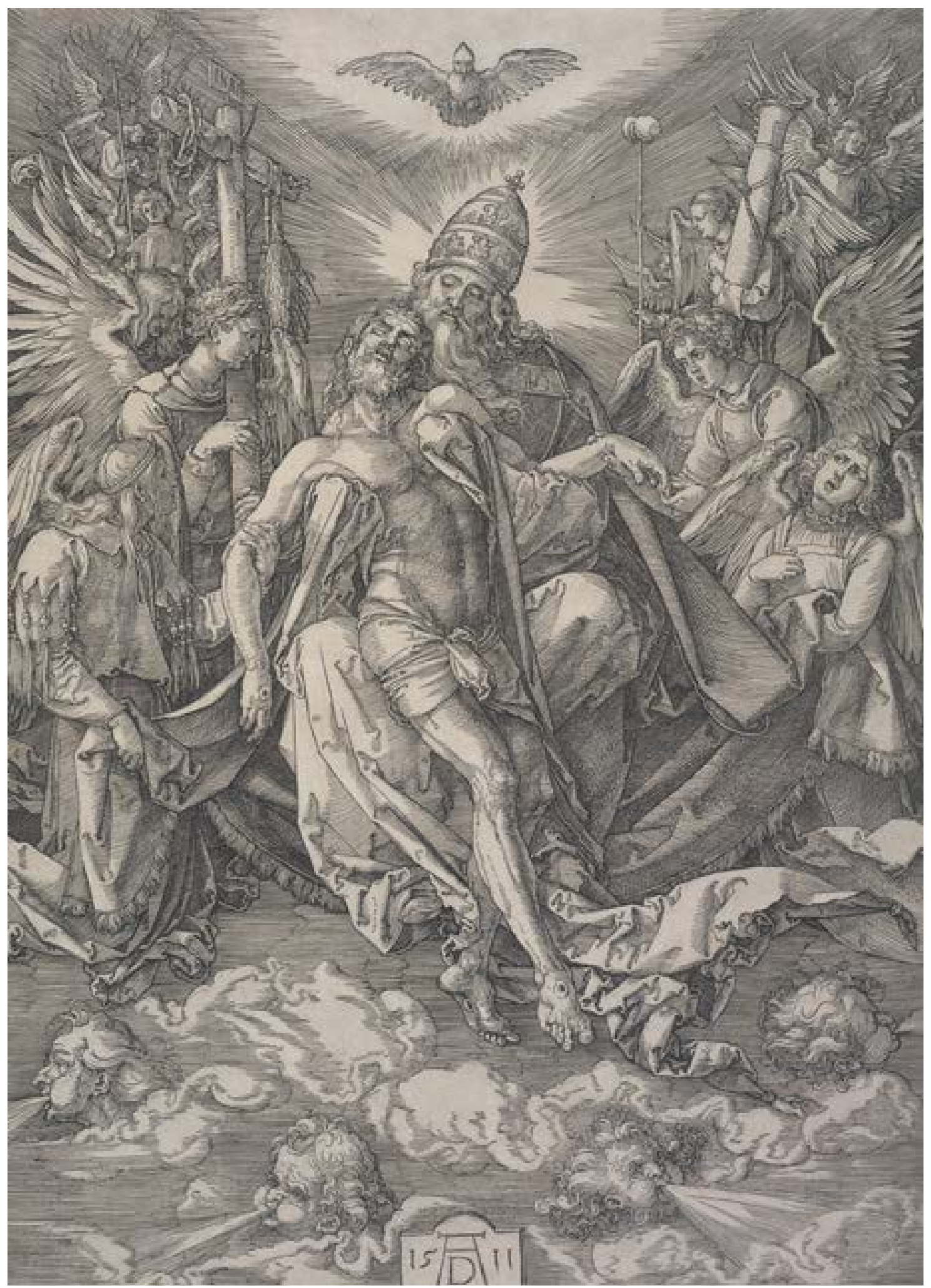

Fig. 3: Albrecht Dürer, Holy Trinity, 1511, woodcut, 394 x 284 mm (Support 394 x 284 mm), Museum of New Zealand Te Papa Tongarewa, Wellington. 


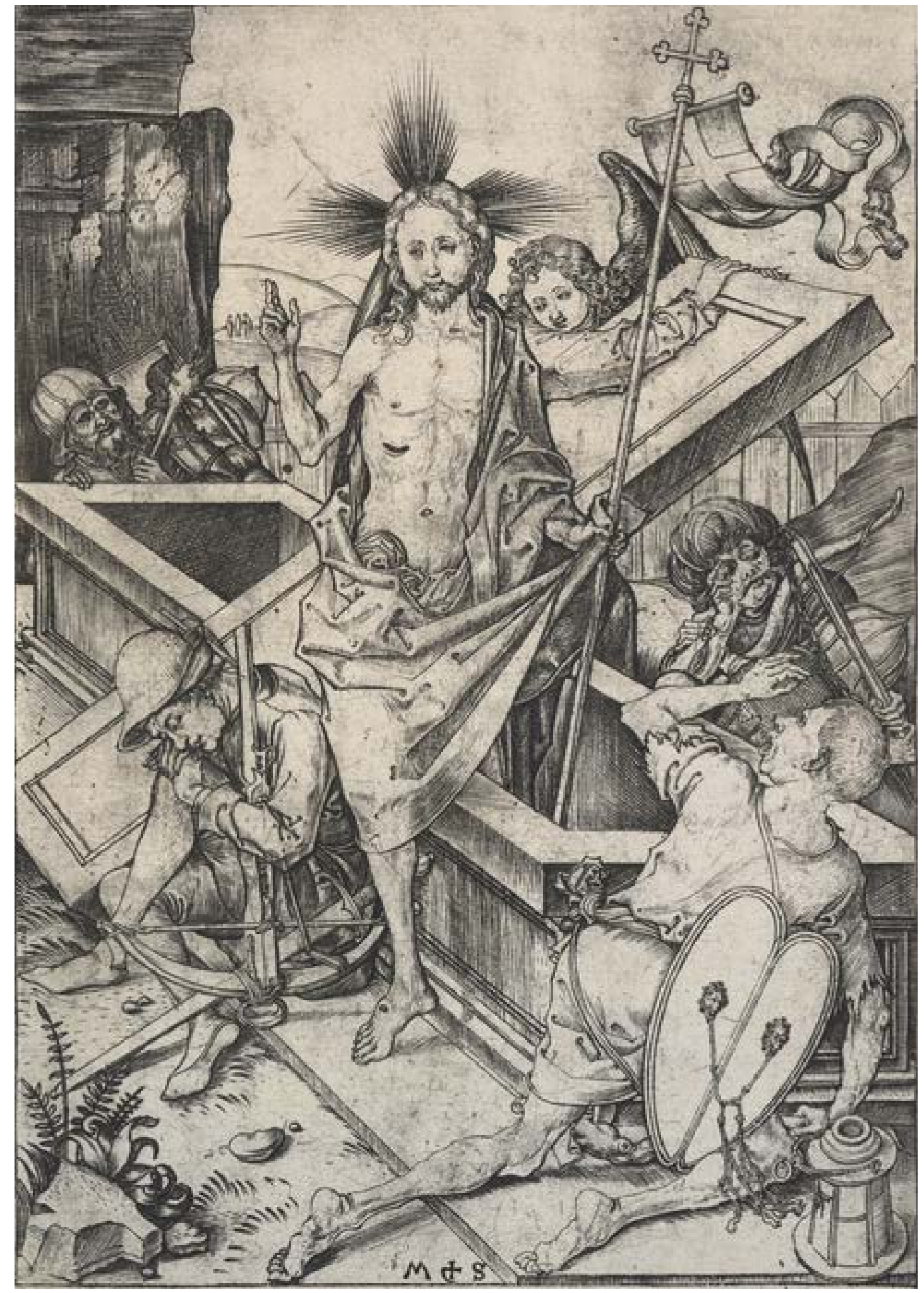

Fig. 4: Martin Schongauer, The Resurrection of Christ, 1470-1482, engraving, 163 x 115 mm (Support 166 x 118 mm), Museum of New Zealand Te Papa Tongarewa, Wellington. 


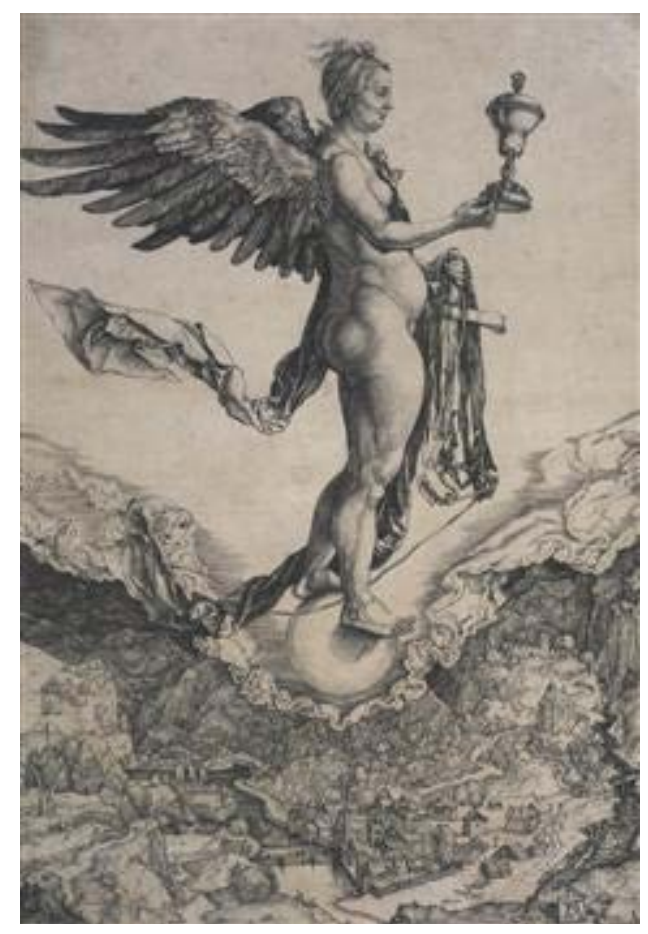

Fig. 5: Albrecht Dürer, Nemesis: The Great Fortune, c. 1501-02, engraving, 333 x 228 mm (Support 333 x 228 mm), Museum of New Zealand Te Papa Tongarewa, Wellington.

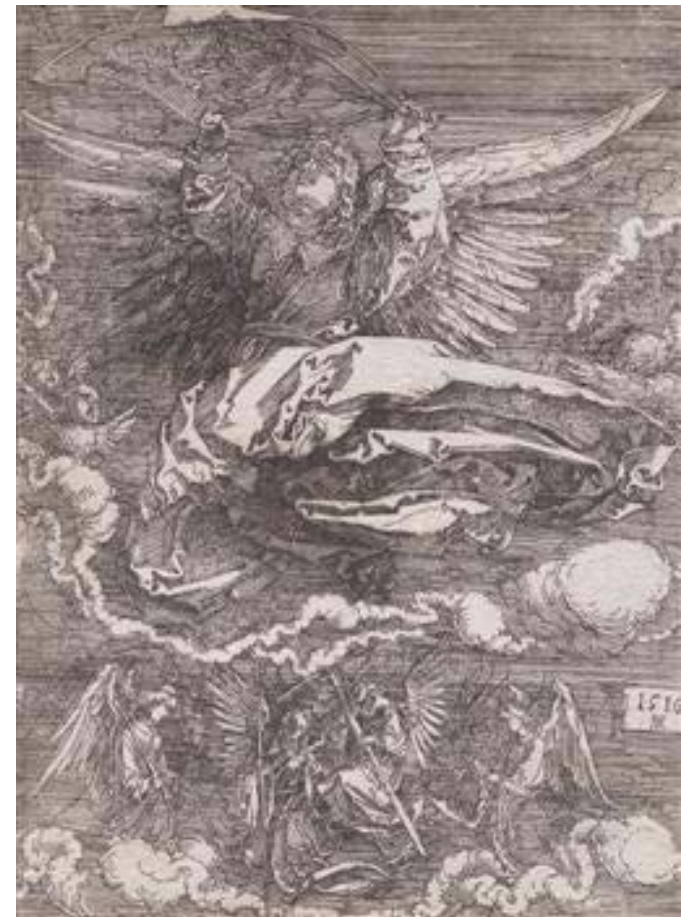

Fig. 6: Albrecht Dürer, The Sudarium held by one angel, 1516, etching, 181 x $132 \mathrm{~mm}$ (support 181 x 132 mm), Museum of New Zealand Te Papa Tongarewa, Wellington. 

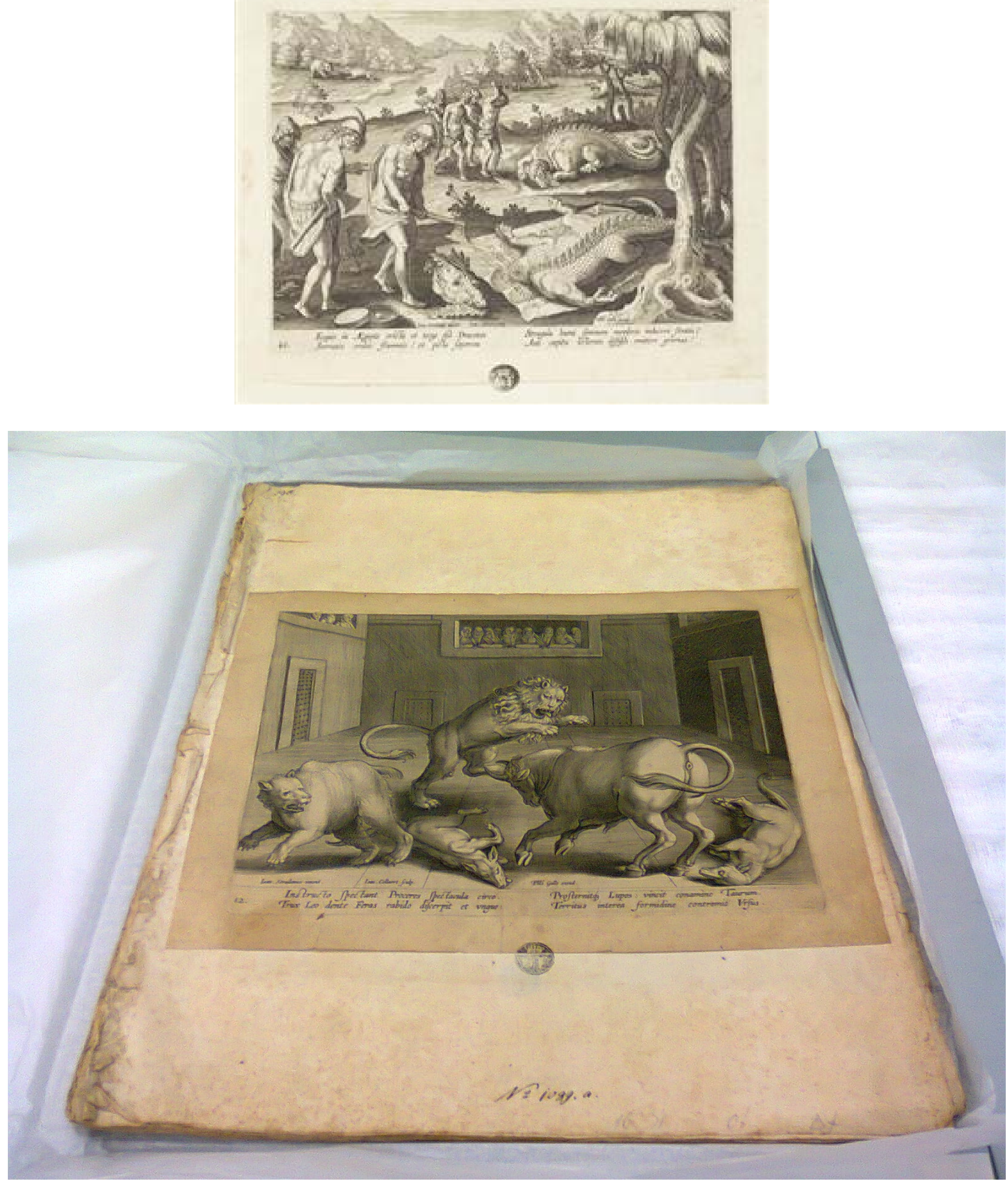

Fig. 7: Jan Collaert, Huntings, plate 7 and plate 1, engraving, overall 408 x 330 mm, Museum of New Zealand Te Papa Tongarewa, Wellington. 


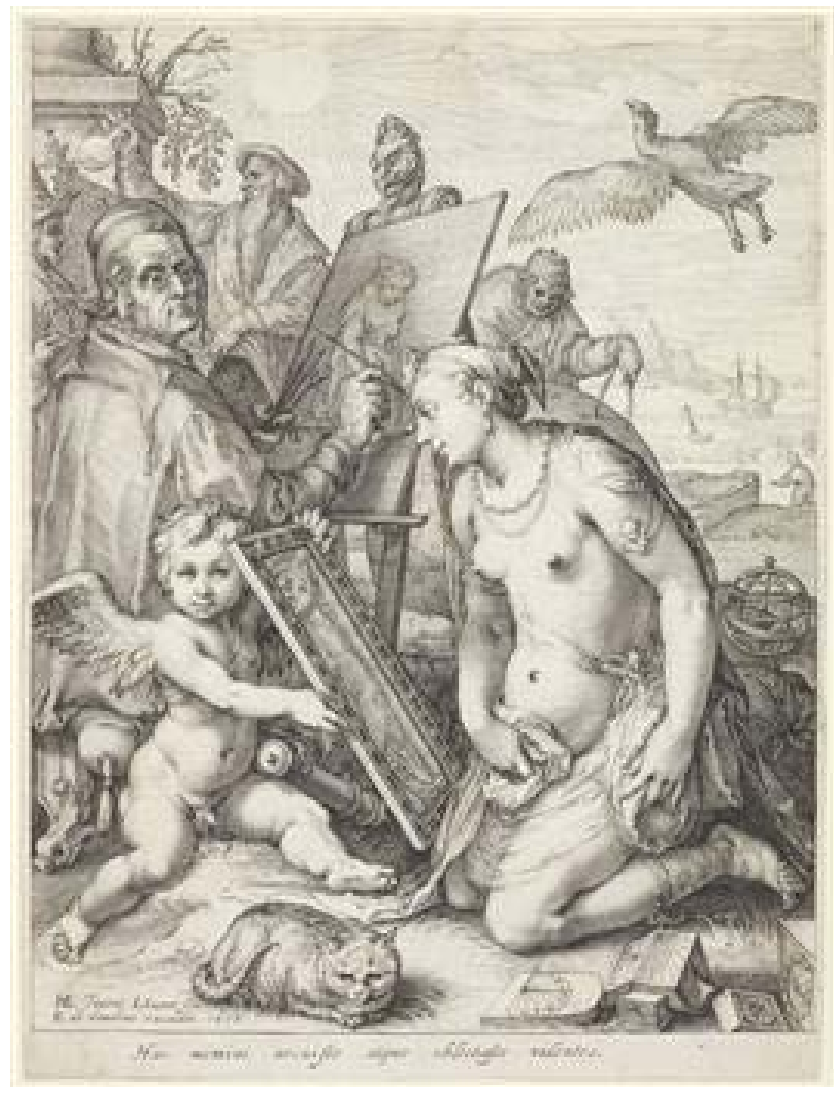

Fig. 8: Jan Saenredam (after Hendrick Goltzius), An allegory of visual perception, published 1616, engraving, 241 x $181 \mathrm{~mm}$ (support 244 x $184 \mathrm{~mm}$ ), Museum of New Zealand Te Papa Tongarewa, Wellington.

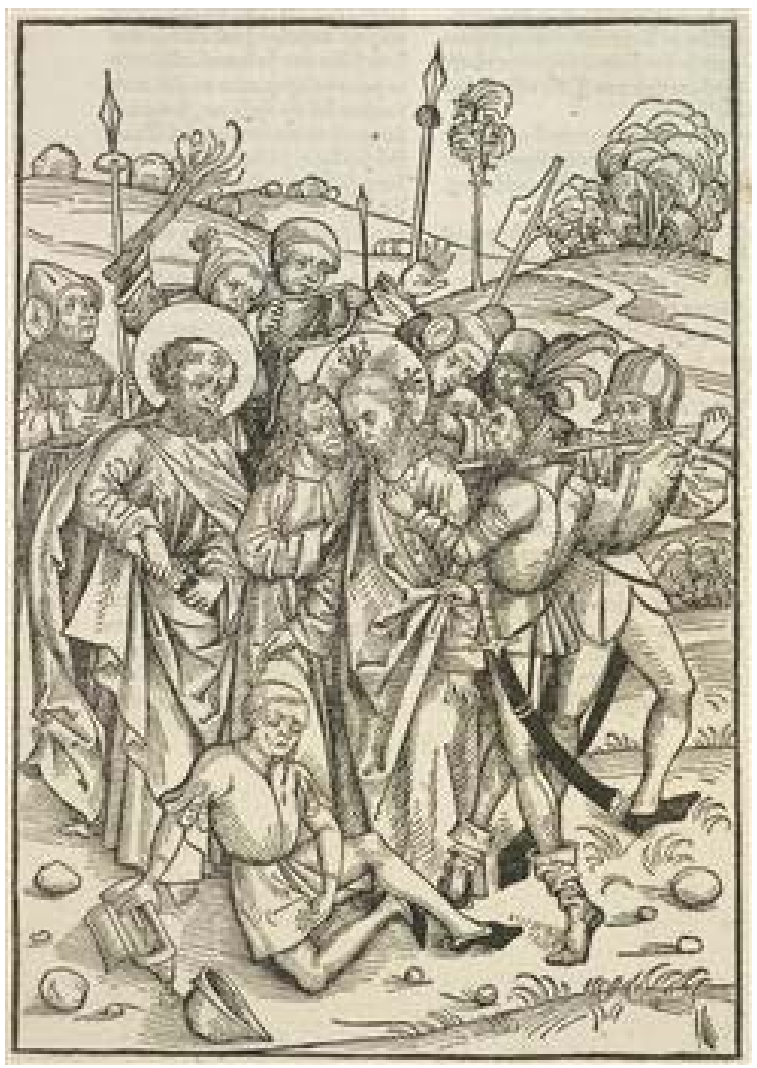

Fig. 9: Michel Wolgemut, The betrayal of Christ, 1491, woodcut, 253 x 178 mm (Support 319 x 216 mm), Museum of New Zealand Te Papa Tongarewa, Wellington. 


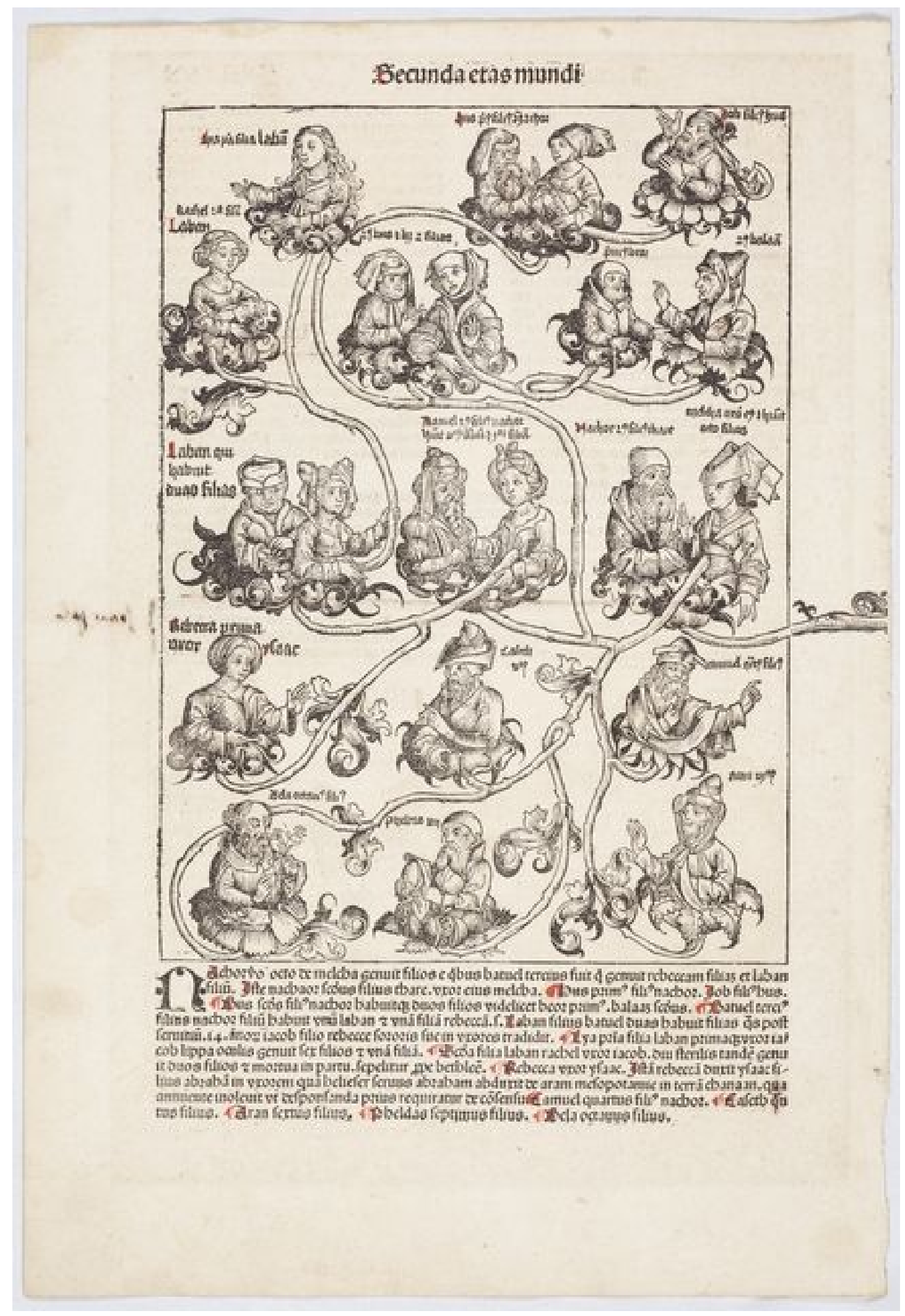

Fig. 10: Unknown, Sexta etas mudi, fol. CCLVI, page from Liber Chronicarum [The Nuremberg Chronicle], 1493, letterpress with red ink capitals and highlights and woodcut, 456 x 310 mm, Museum of New Zealand Te Papa Tongarewa, Wellington. 

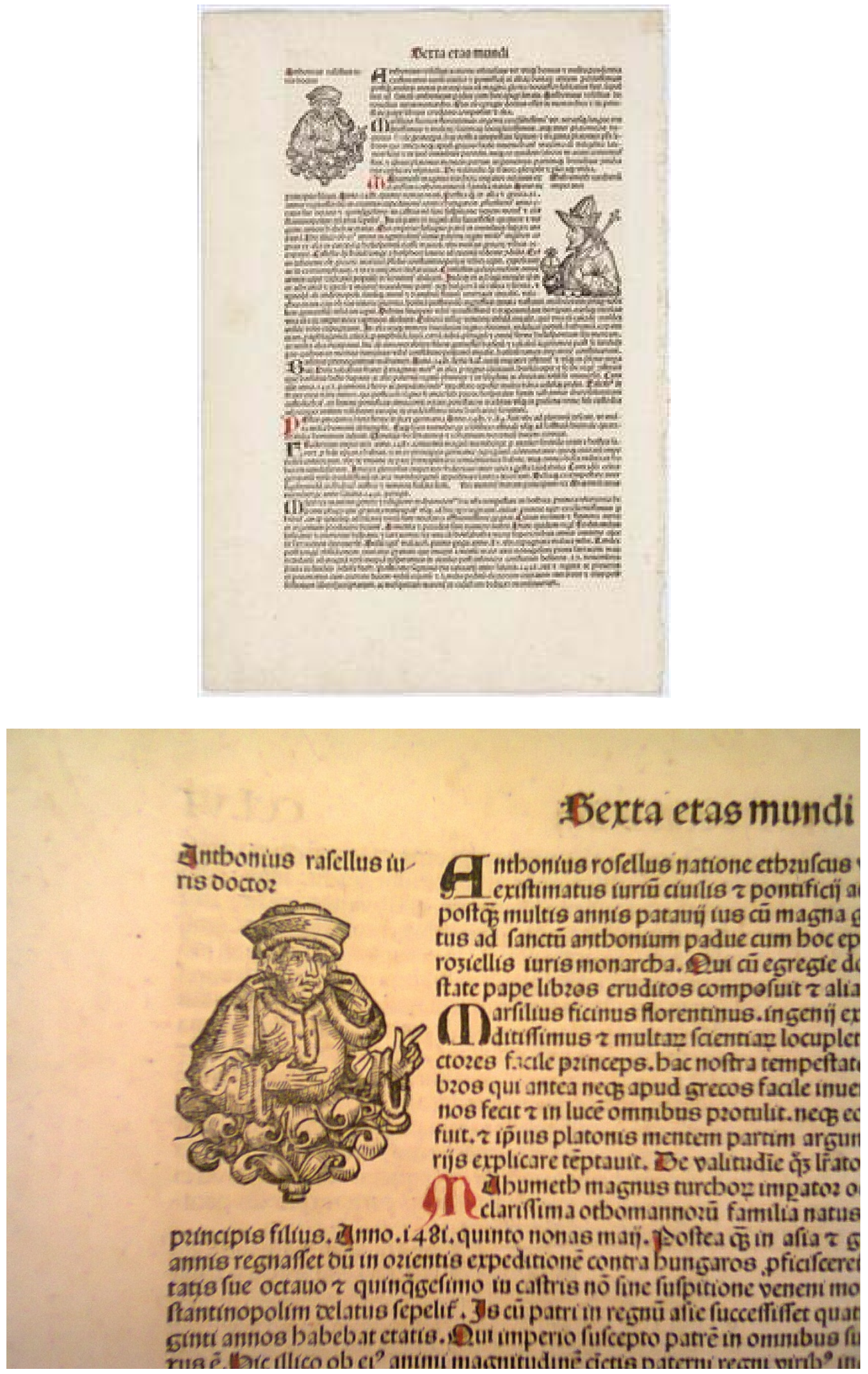

Fig. 11: Michel Wolgemut, Secunda etas mundi, fol.XX, page from Liber Chronicarum [The Nuremberg Chronicle], 1493, letterpress with red ink capitals and highlights and woodcut, 456 x 310 mm, Museum of New Zealand Te Papa Tongarewa, Wellington. 

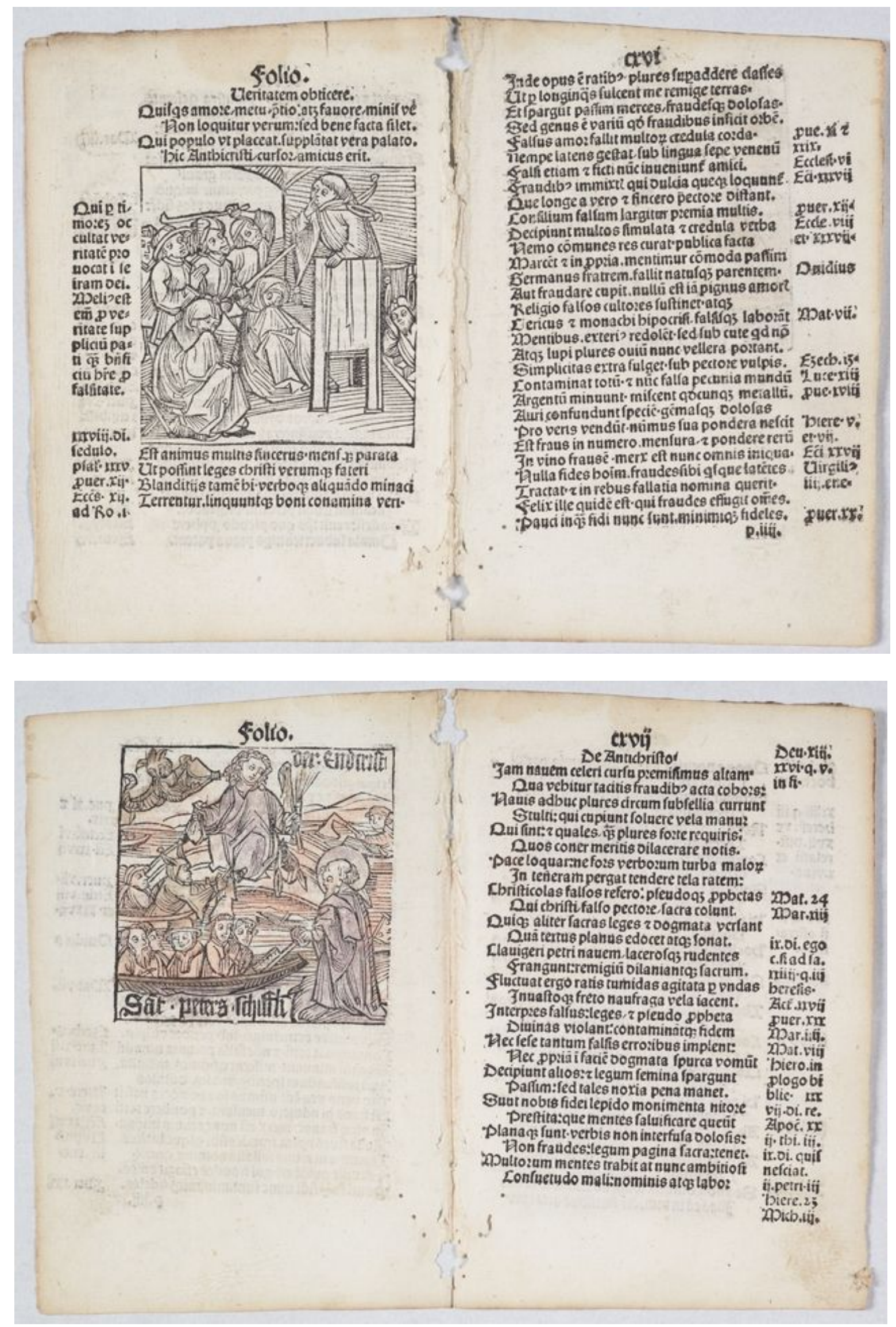

Fig. 12: Unknown, Two pages from Sebastian Brant's Stultifera Navis [The Ship of Fools], woodcut and letterpress, 145 x 99 mm, Museum of New Zealand Te Papa Tongarewa, Wellington. 

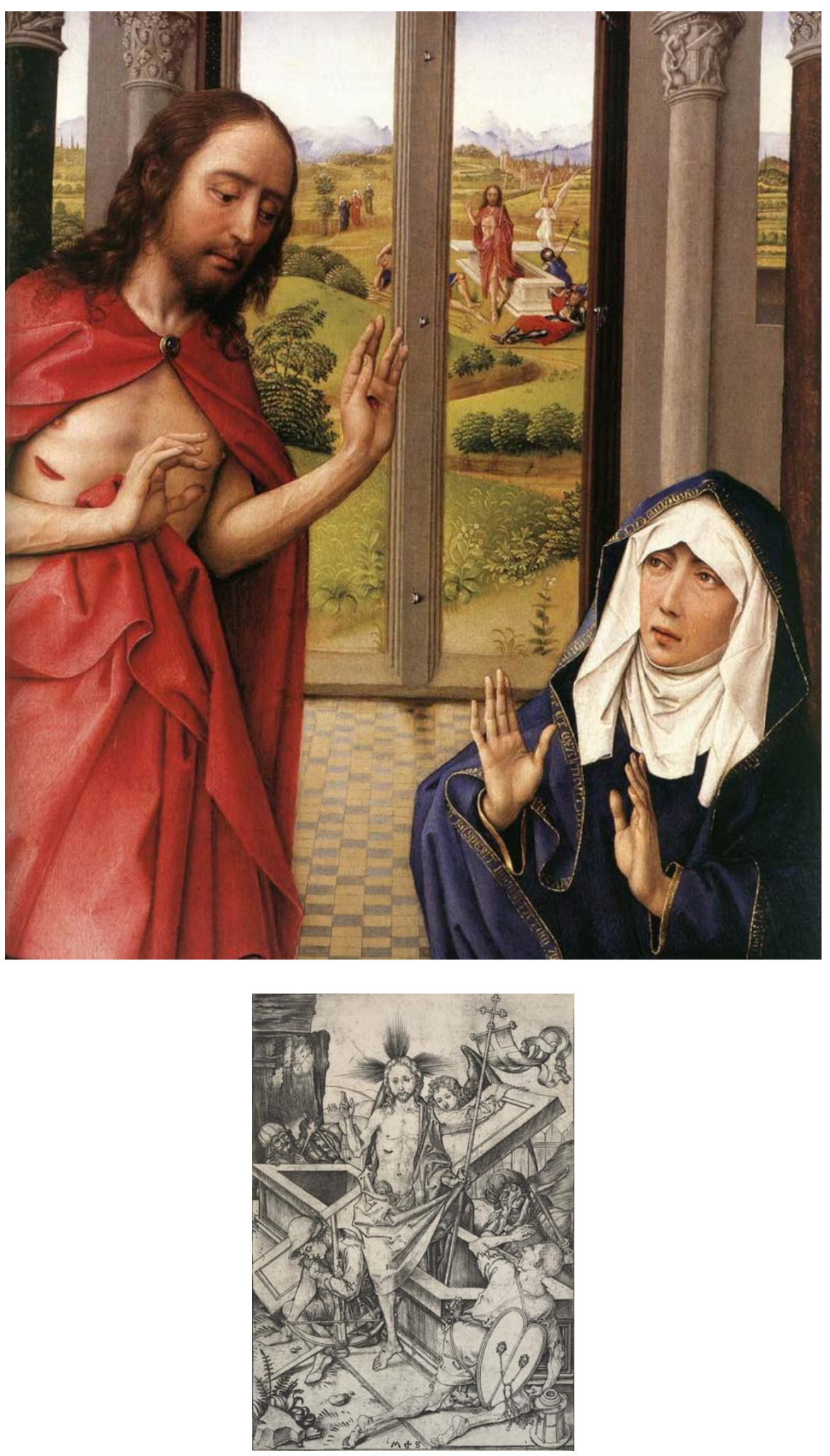

Fig. 13: Rogier van der Weyden, The Miraflores Altarpiece, detail, c. 1442-5, oil on panel, $220.5 \mathrm{~cm} \times 259.5 \mathrm{~cm}$, Gemäldegalerie, Berlin. 


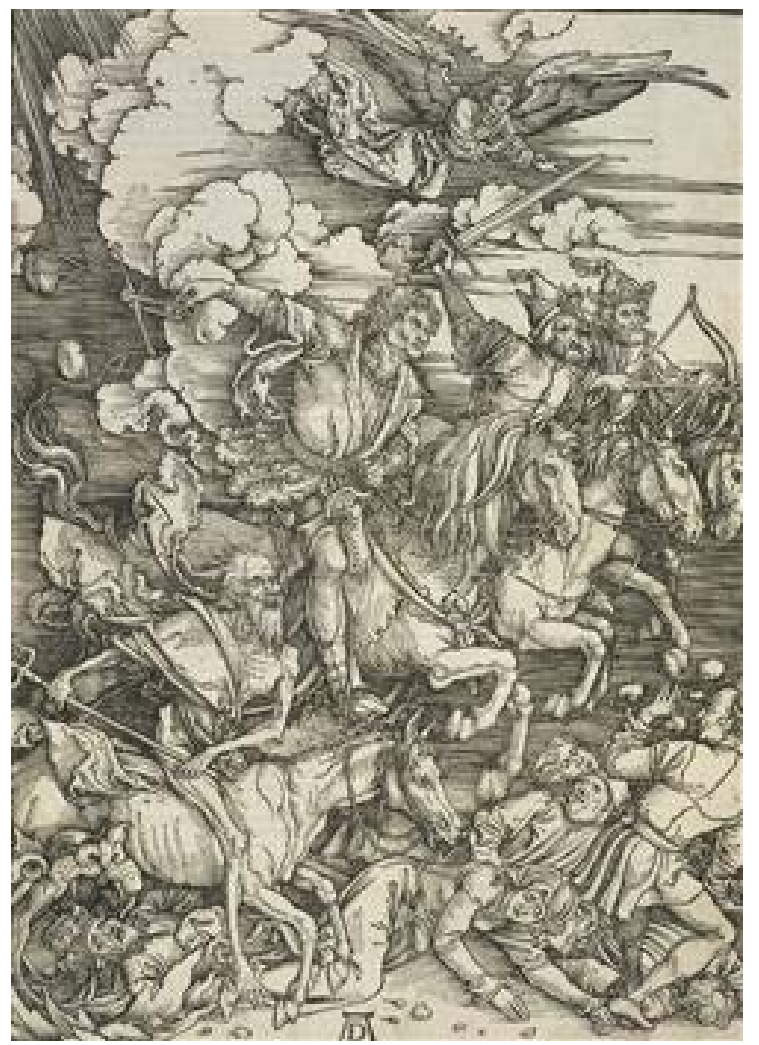

Fig. 14: Albrecht Dürer, Four Horsemen of the Apocalypse, 1497-98, woodcut, 381 x 275 mm, Museum of New Zealand Te Papa Tongarewa, Wellington.

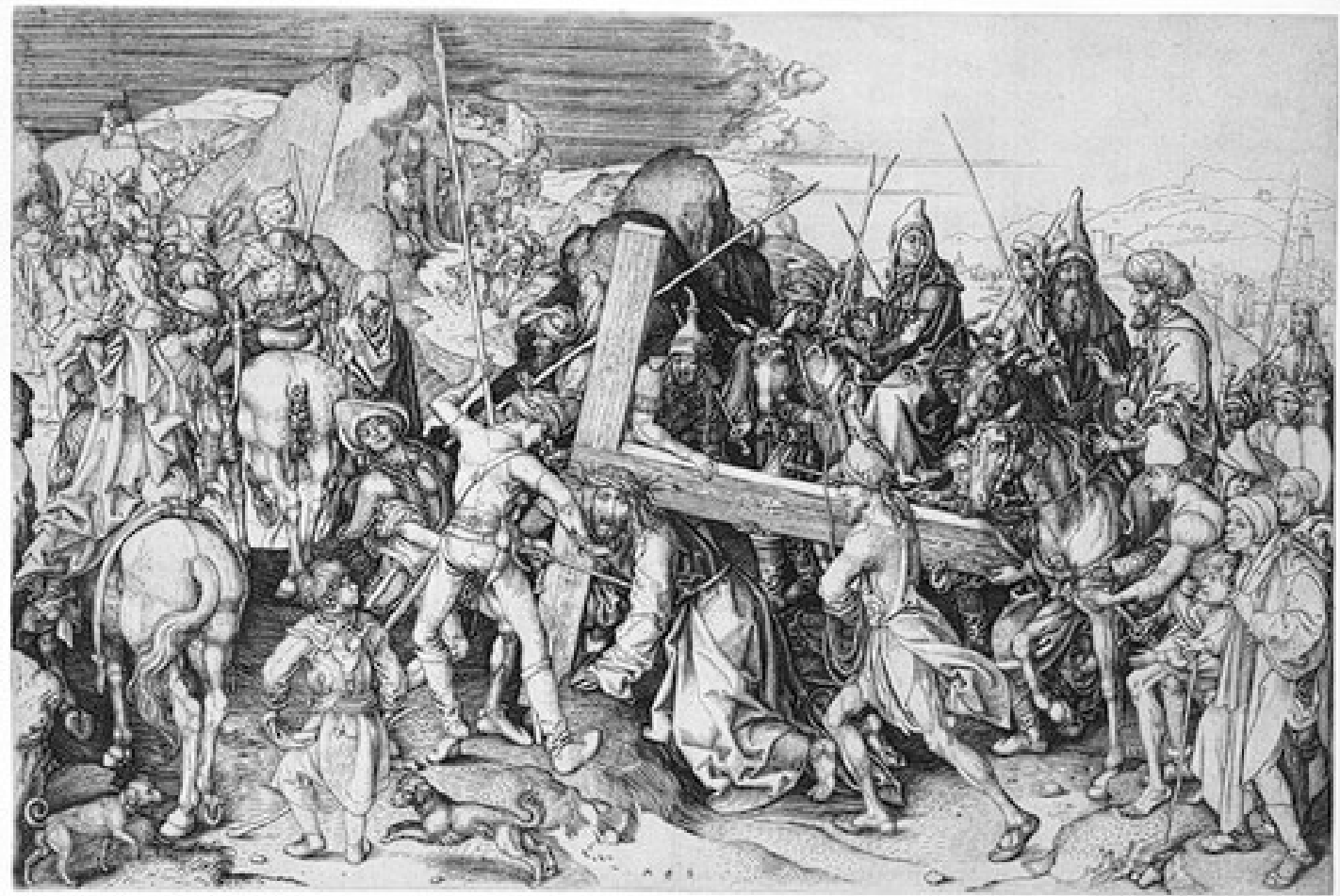

Fig. 15: Martin Schongauer, Carrying of the cross, c. 1475-80, engraving, 28.9 x $42.9 \mathrm{~cm}$, Metropolitan Museum of Art, New York. 


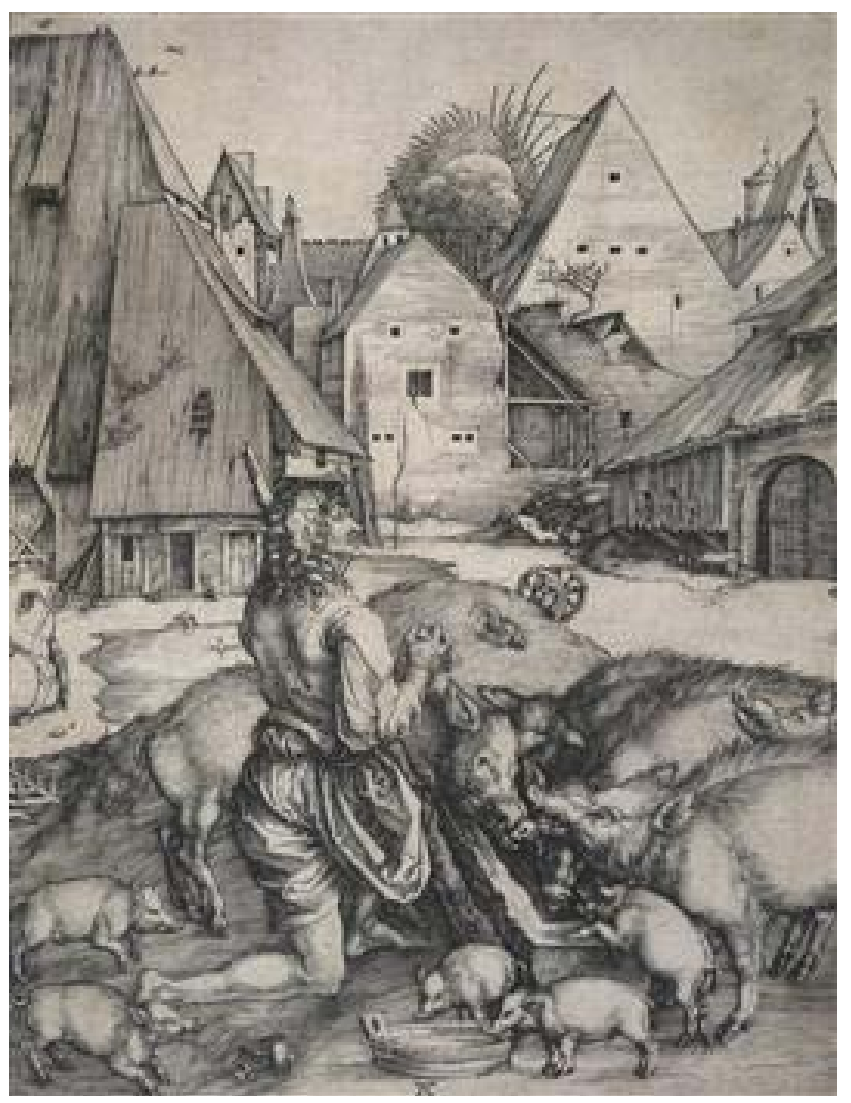

Fig. 16: Albrecht Dürer, The Prodigal Son amid the Swine, 1496, engraving, 250 x $190 \mathrm{~mm}$ (Support 250 x 191 mm), Museum of New Zealand Te Papa Tongarewa, Wellington.

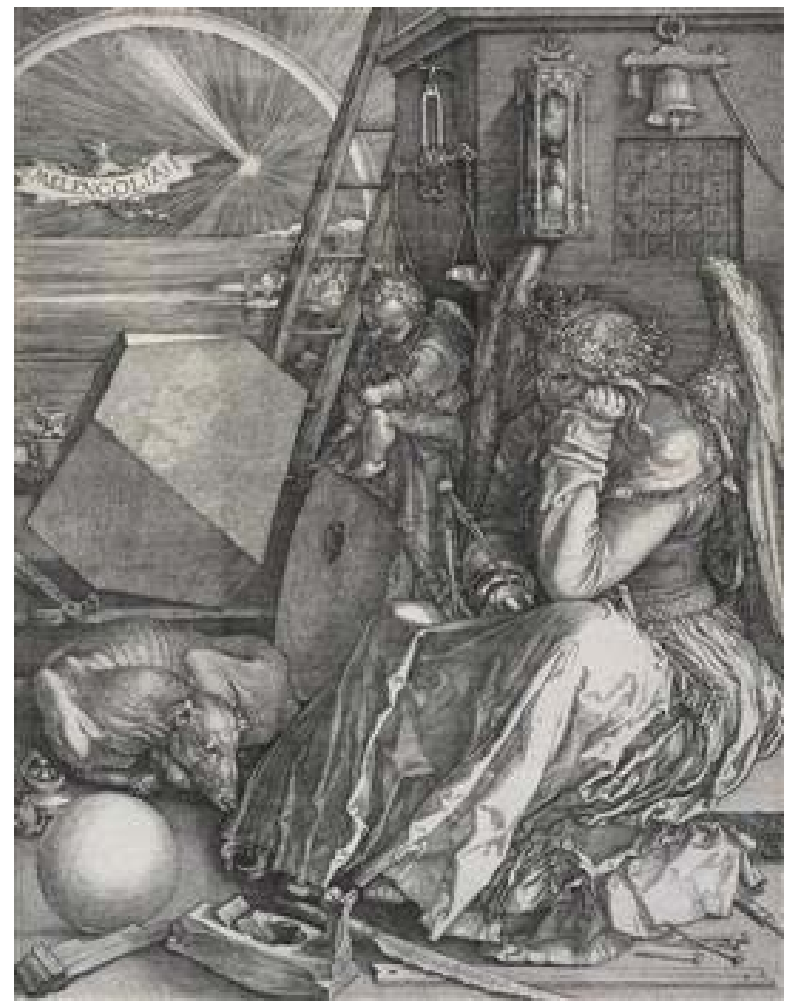

Fig. 17: Albrecht Dürer, Melencolia I, 1514, engraving, 238 x 186 mm (Support 238 x 186 mm), 1959-0023-1, Museum of New Zealand Te Papa Tongarewa, Wellington. 


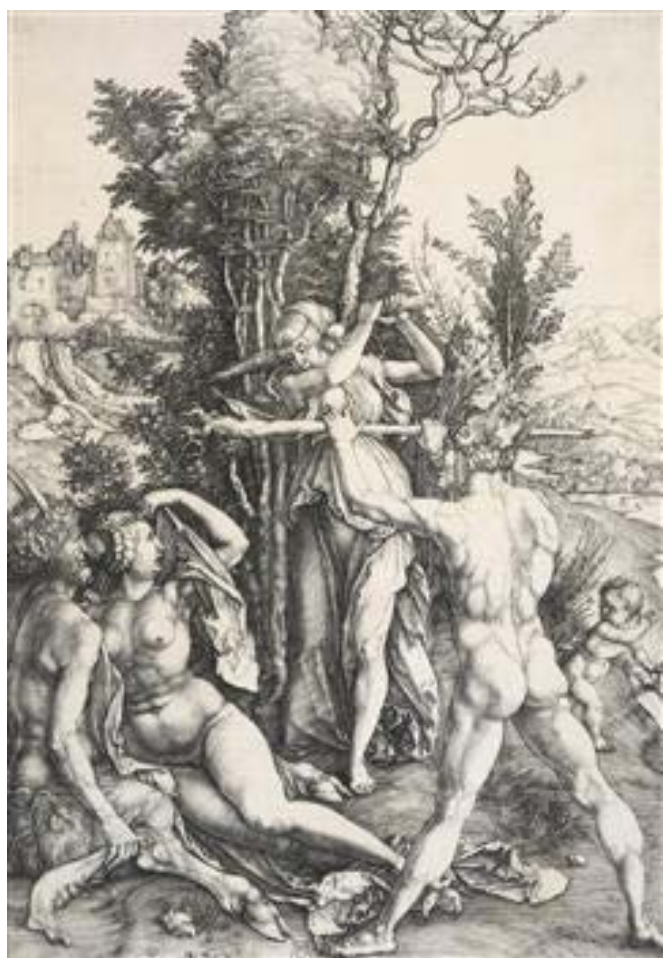

Fig. 18: Albrecht Dürer, Hercules, c. 1498, engraving, 320 x 220 mm (Support 321 x 222 $\mathrm{mm})$, Museum of New Zealand Te Papa Tongarewa, Wellington.

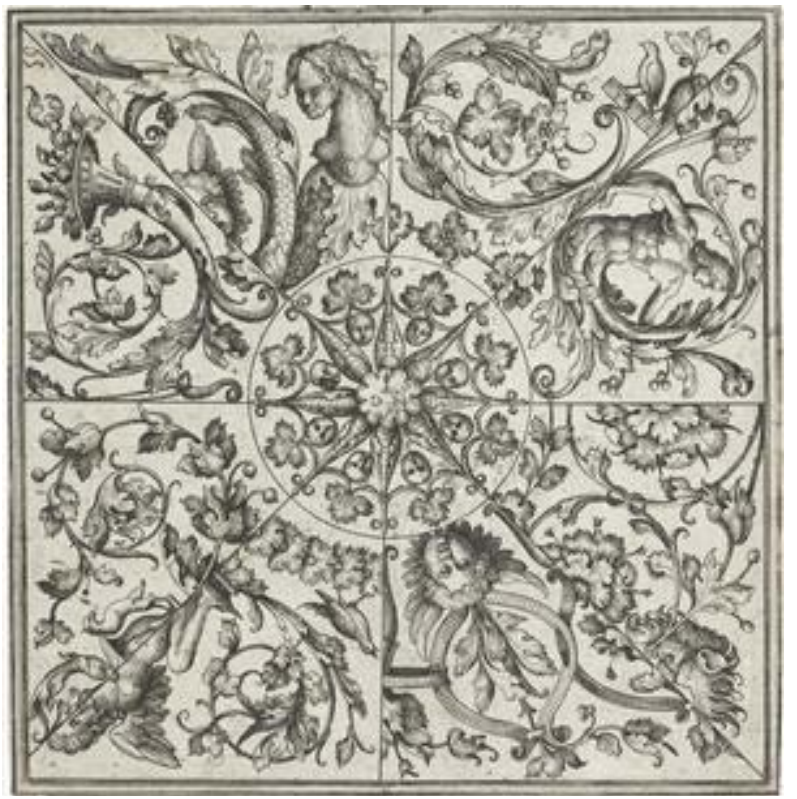

Fig. 19: Daniel Hopfer, Geometric design for an ornamented ceiling, 1505-1536, etching, 228 x 224 mm, Museum of New Zealand Te Papa Tongarewa, Wellington. 


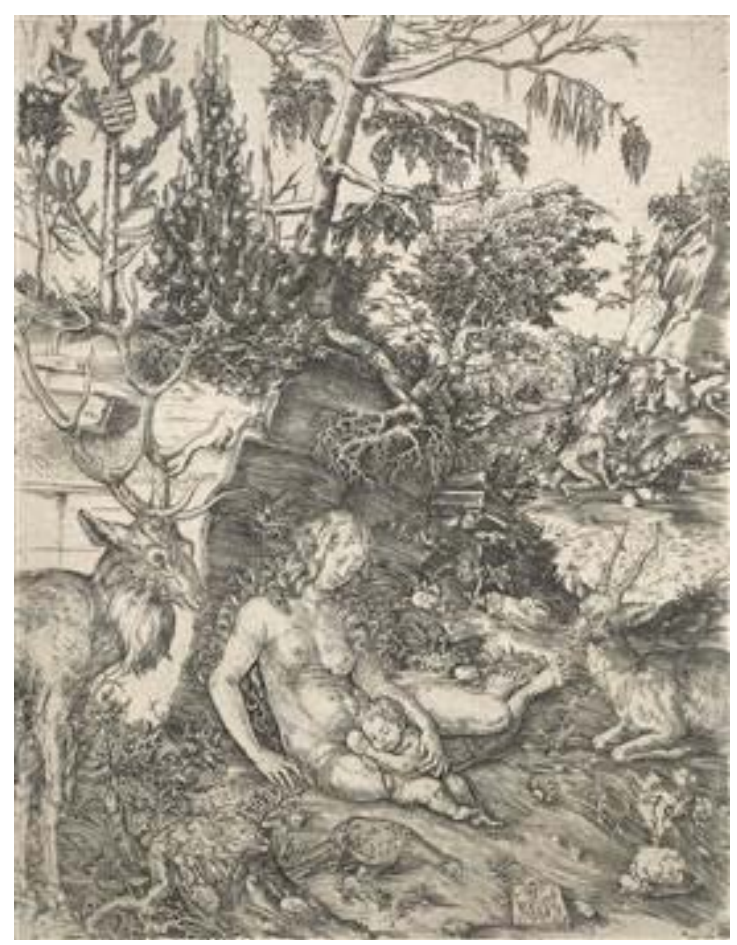

Fig. 20: Lucas Cranach, Penance of St John Chrysostom, 1509, engraving, 254 x 200 mm (Support 259 x 204 mm), Museum of New Zealand Te Papa Tongarewa, Wellington.

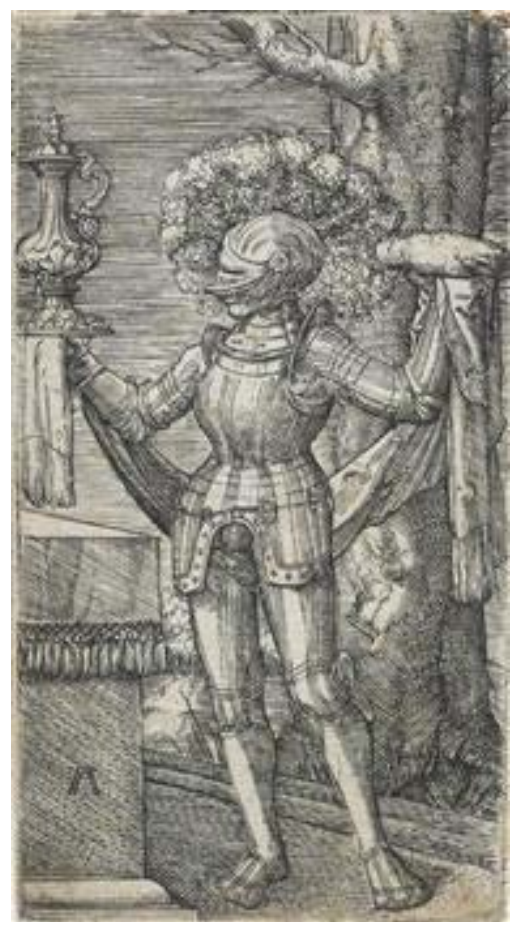

Fig. 21: Albrecht Altdorfer, Knight with bread and wine (Melchisedek), 1520-1526, engraving, 88 x $47 \mathrm{~mm}$ (Support 89 x $48 \mathrm{~mm}$ ), Museum of New Zealand Te Papa Tongarewa, Wellington. 


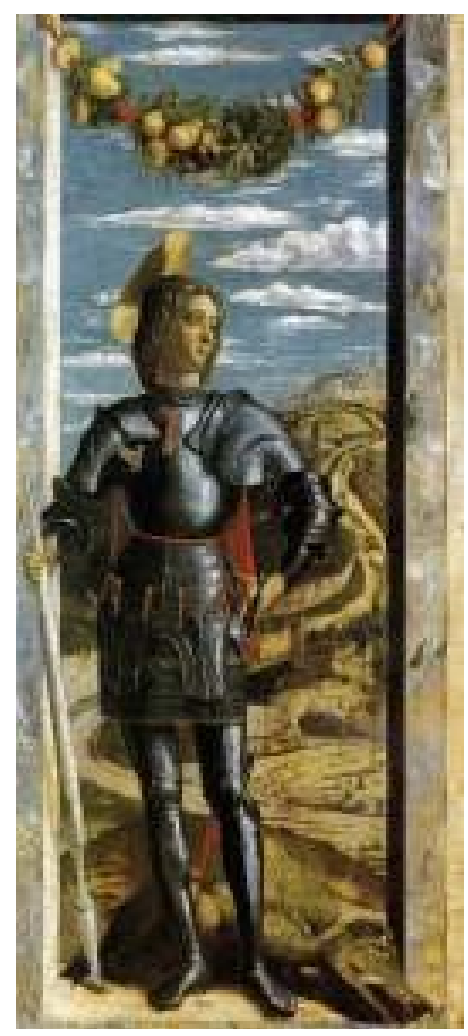

Fig. 22: Andrea Mantegna, St George, c. 1460, tempera on panel, 66 x 32 cm, Gallerie dell'Accademia, Venice.

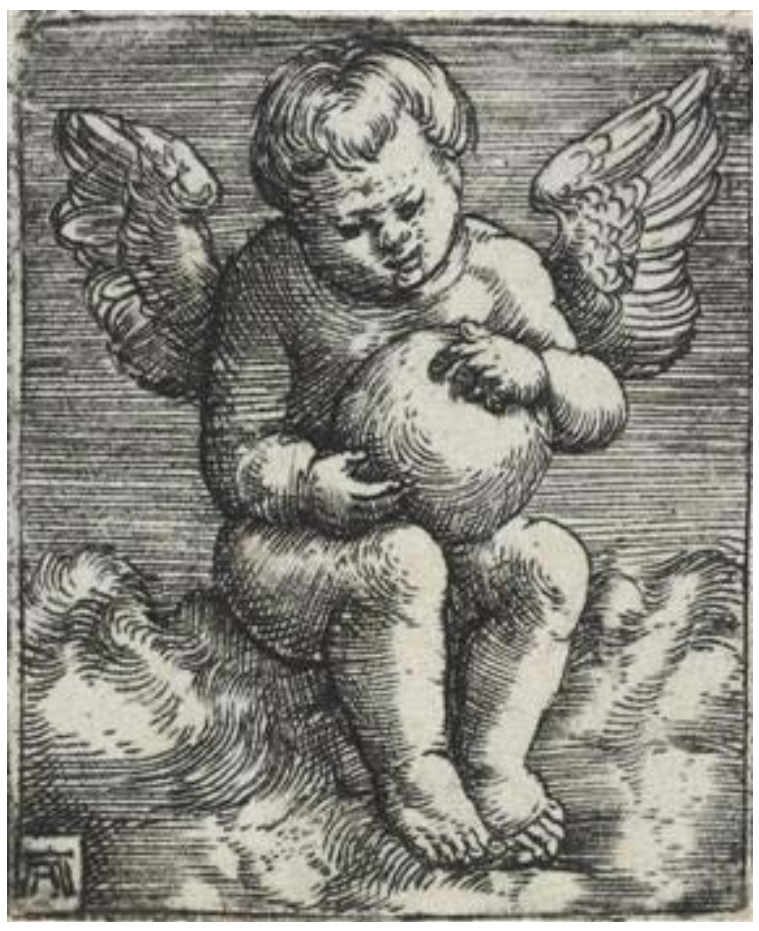

Fig.23: Albrecht Altdorfer, Genius with a pair of bellows, 1520-1526, engraving, 30 x 25 mm (Support 32 x 27 mm), Museum of New Zealand Te Papa Tongarewa, Wellington. 


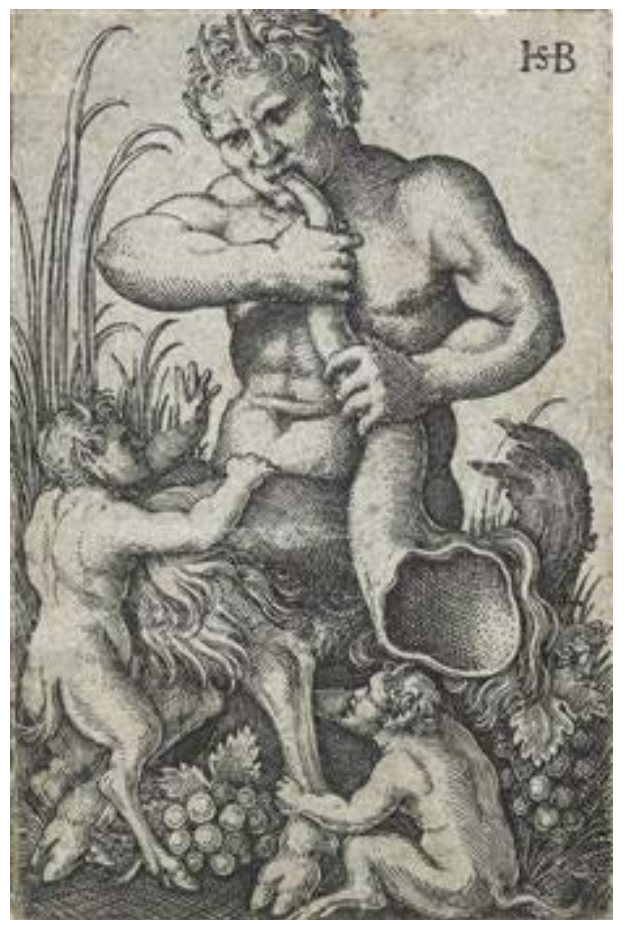

Fig. 24: Hans Sebald Beham, Satyr sounding a horn, 1531-1550, engraving, 58 x 40 mm (Support 58 x 40 mm), Museum of New Zealand Te Papa Tongarewa, Wellington.

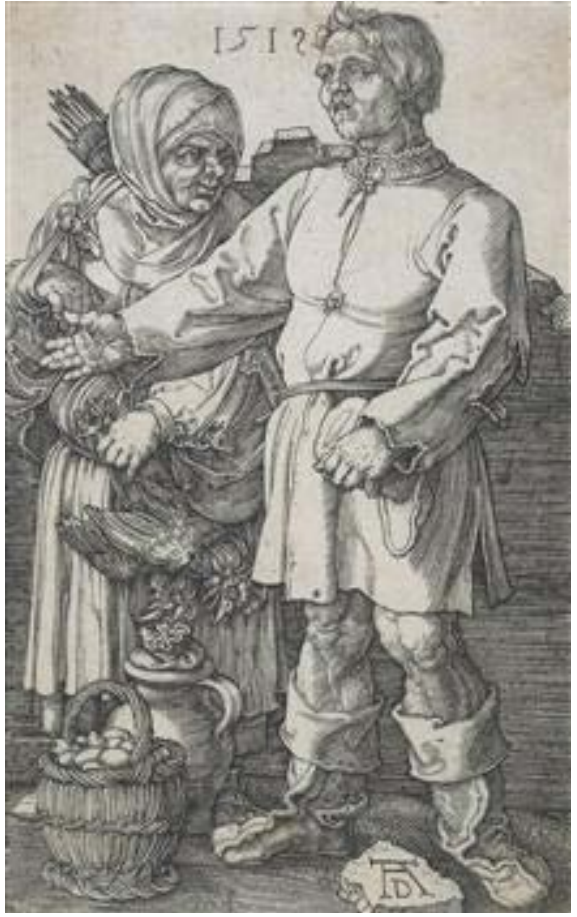

Fig. 25: Albrecht Dürer, The peasant couple at market, 1519, engraving, 115 x $72 \mathrm{~mm}$ (Support 115 x 72 mm), Museum of New Zealand Te Papa Tongarewa, Wellington. 

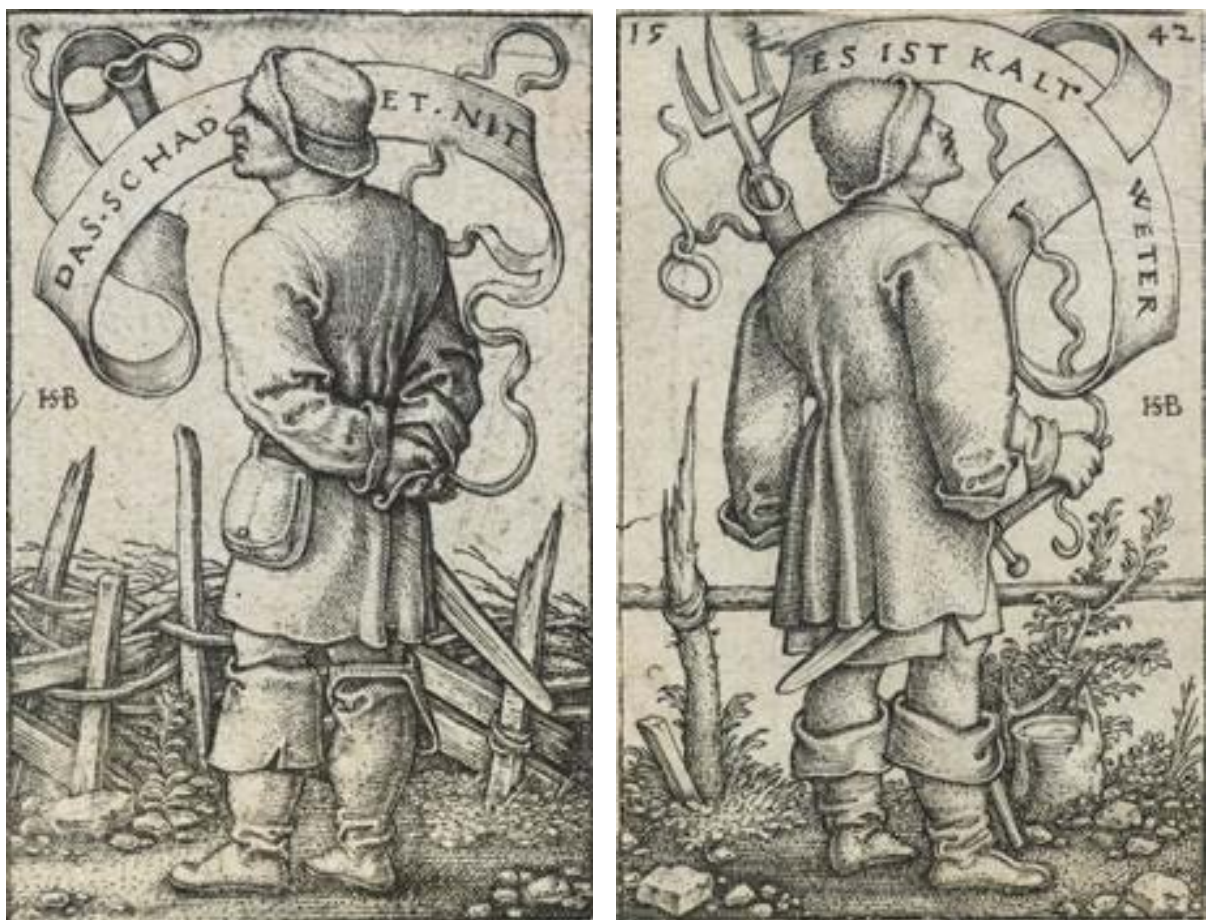

Fig. 26: Hans Sebald Beham, Weather Peasants, "Das schadet nit" and "Es ist kalt weter", 1542, engraving, 45 x 29 mm (Support 45 x 29 mm), Museum of New Zealand Te Papa Tongarewa, Wellington.

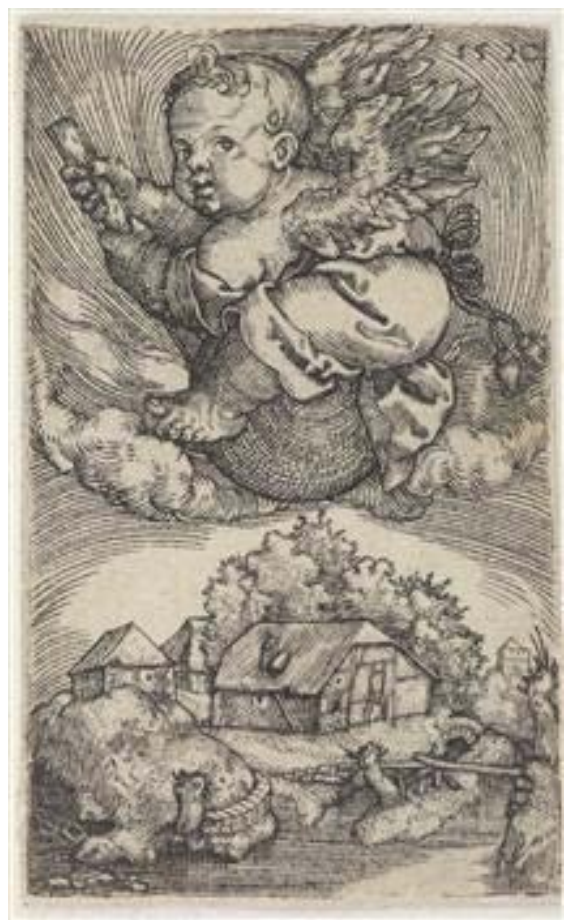

Fig. 27: Barthel Beham, A genius on a globe flying above a landscape, 1520, engraving, $59 \mathrm{x}$ 37 mm (Support 59 x 37 mm), Museum of New Zealand Te Papa Tongarewa, Wellington. 


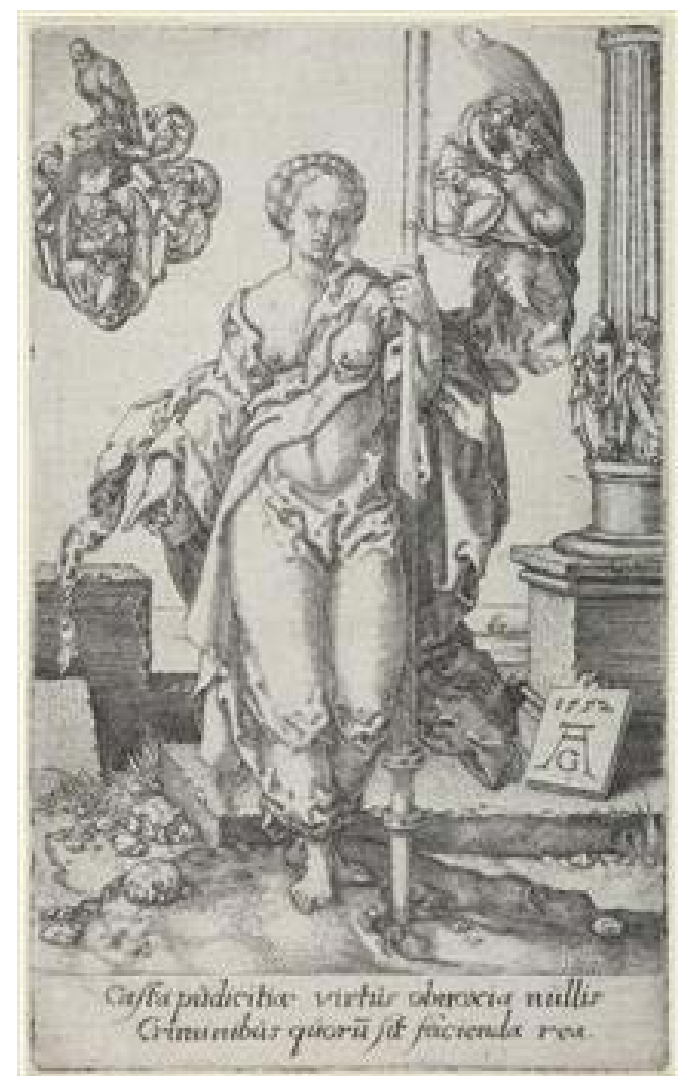

Fig. 28: Heinrich Aldegrever, Chastity, 1552, engraving, 94 x 63 mm (Support 104 x 64 $\mathrm{mm}$ ), Museum of New Zealand Te Papa Tongarewa, Wellington.

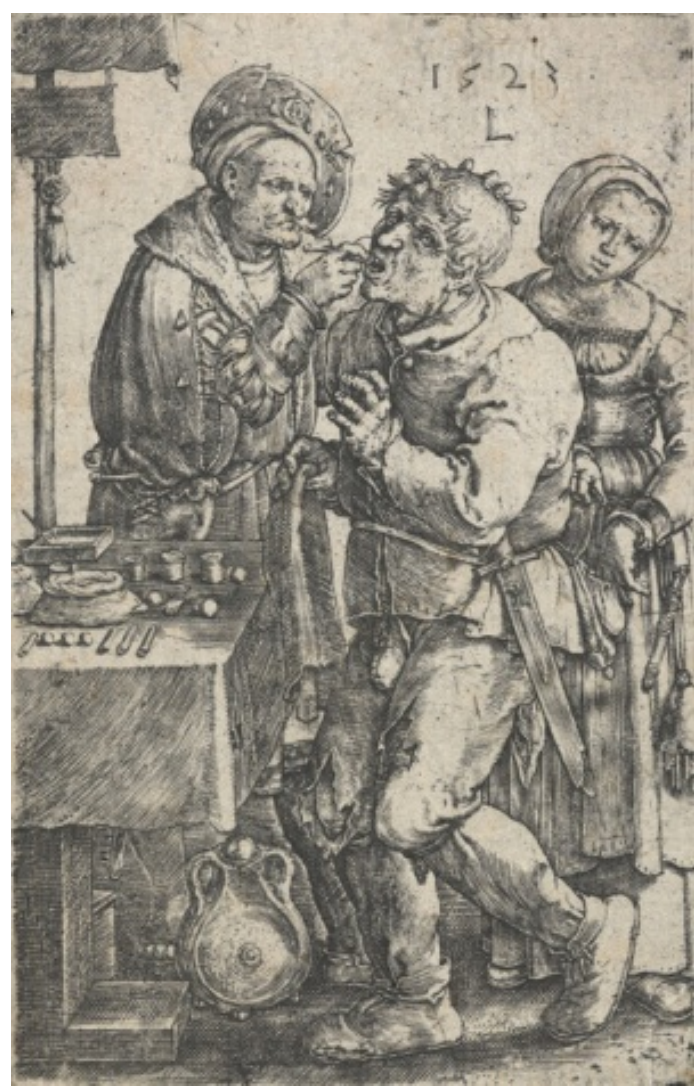

Fig. 29: Lucas van Leyden, The dentist, 1523, engraving, 117 x 75 mm (Support 117 x 77 mm; Secondary support 128 x 88 mm), Museum of New Zealand Te Papa Tongarewa, Wellington. 


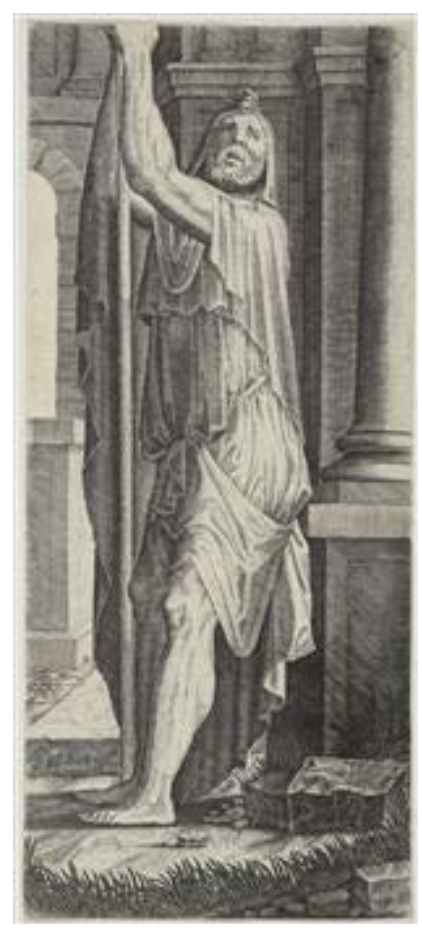

Fig. 30: Lambert Suavius, St. Matthias, c. 1545, engraving, 195 x 84 mm, Museum of New Zealand Te Papa Tongarewa, Wellington.

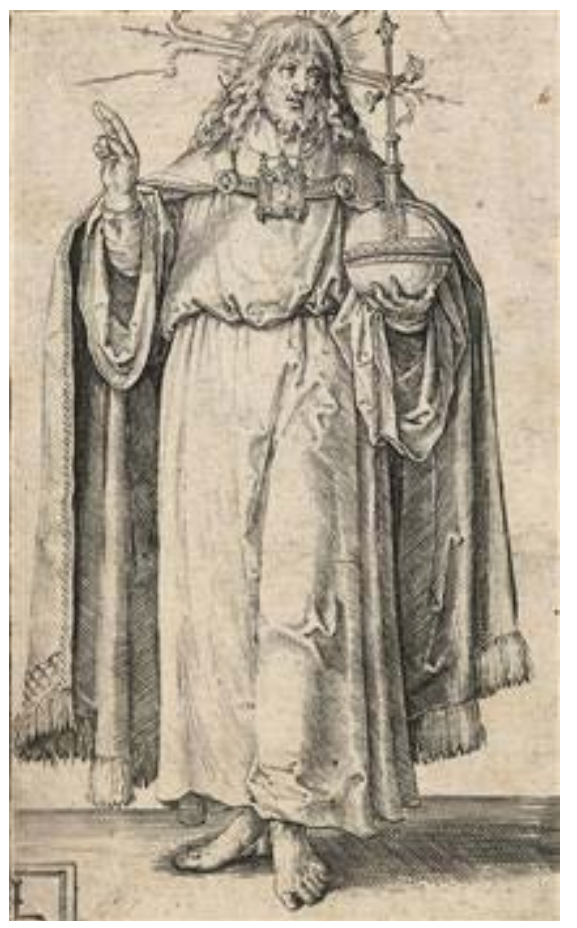

Fig. 31: Lucas van Leyden, Christ, 1510, engraving, 116 x 73 mm (Support 116 x 73 mm), Museum of New Zealand Te Papa Tongarewa, Wellington. 


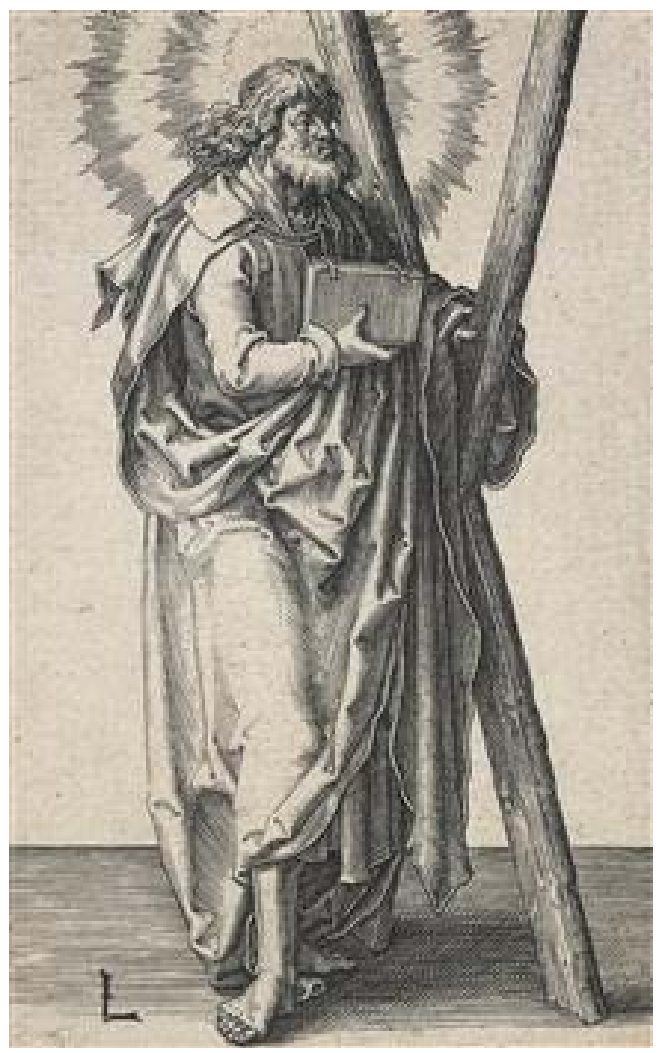

Fig. 32: Lucas van Leyden, Andrew, 1510, engraving, 112 x 70 mm (Support 112 x 70 mm), Museum of New Zealand Te Papa Tongarewa, Wellington.

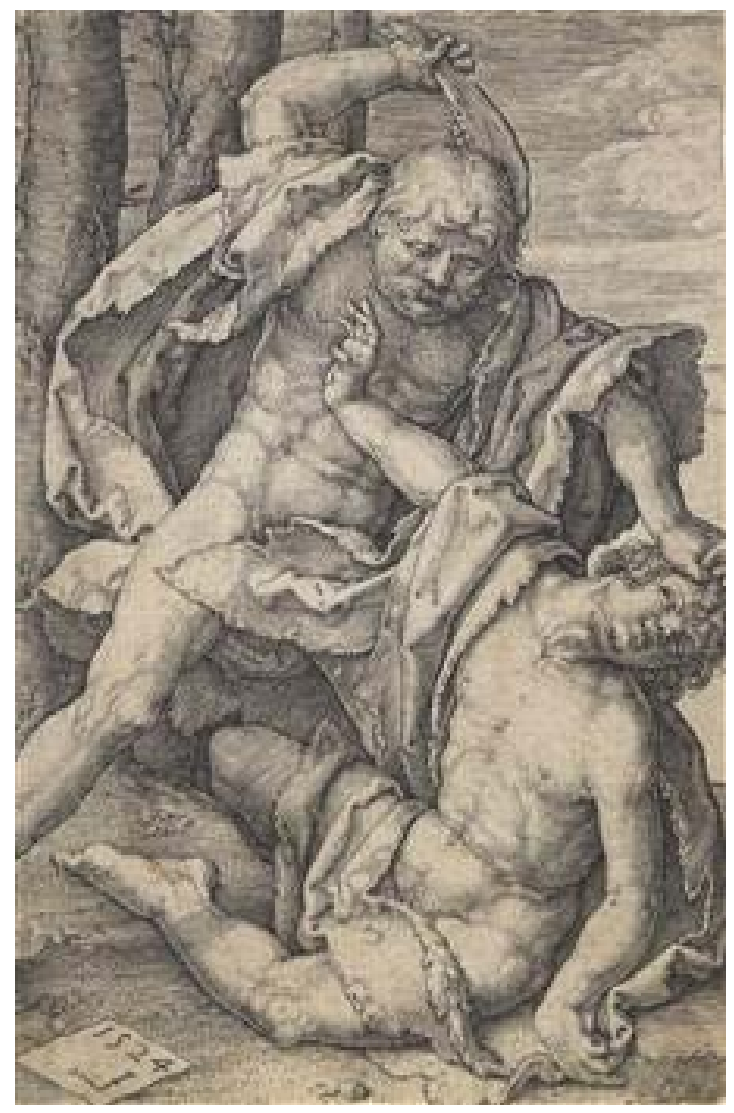

Fig. 33: Lucas van Leyden, Cain killing Abel, 1524, engraving, 115 x 74 mm (Support 115 x $74 \mathrm{~mm}$ ), Museum of New Zealand Te Papa Tongarewa, Wellington. 


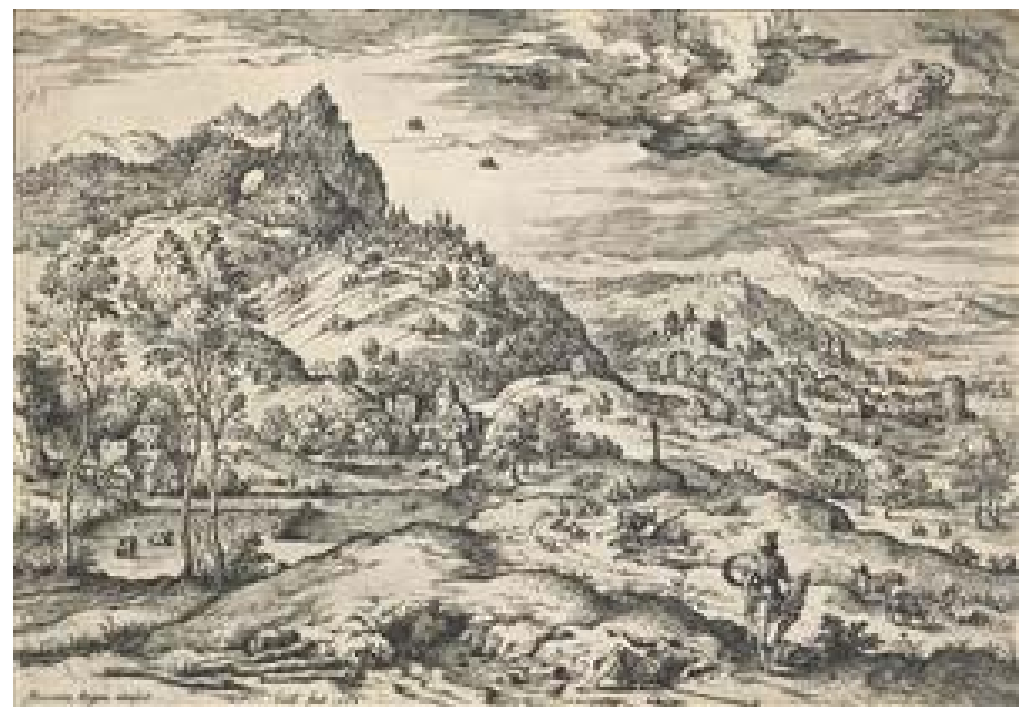

Fig. 34: Hieronymus Cock (after Matthijs Cock), Mercury with the head of Argus in his hand, 1558, etching, 225 x 324 mm (Support 228 x 327 mm), Museum of New Zealand Te Papa Tongarewa, Wellington.

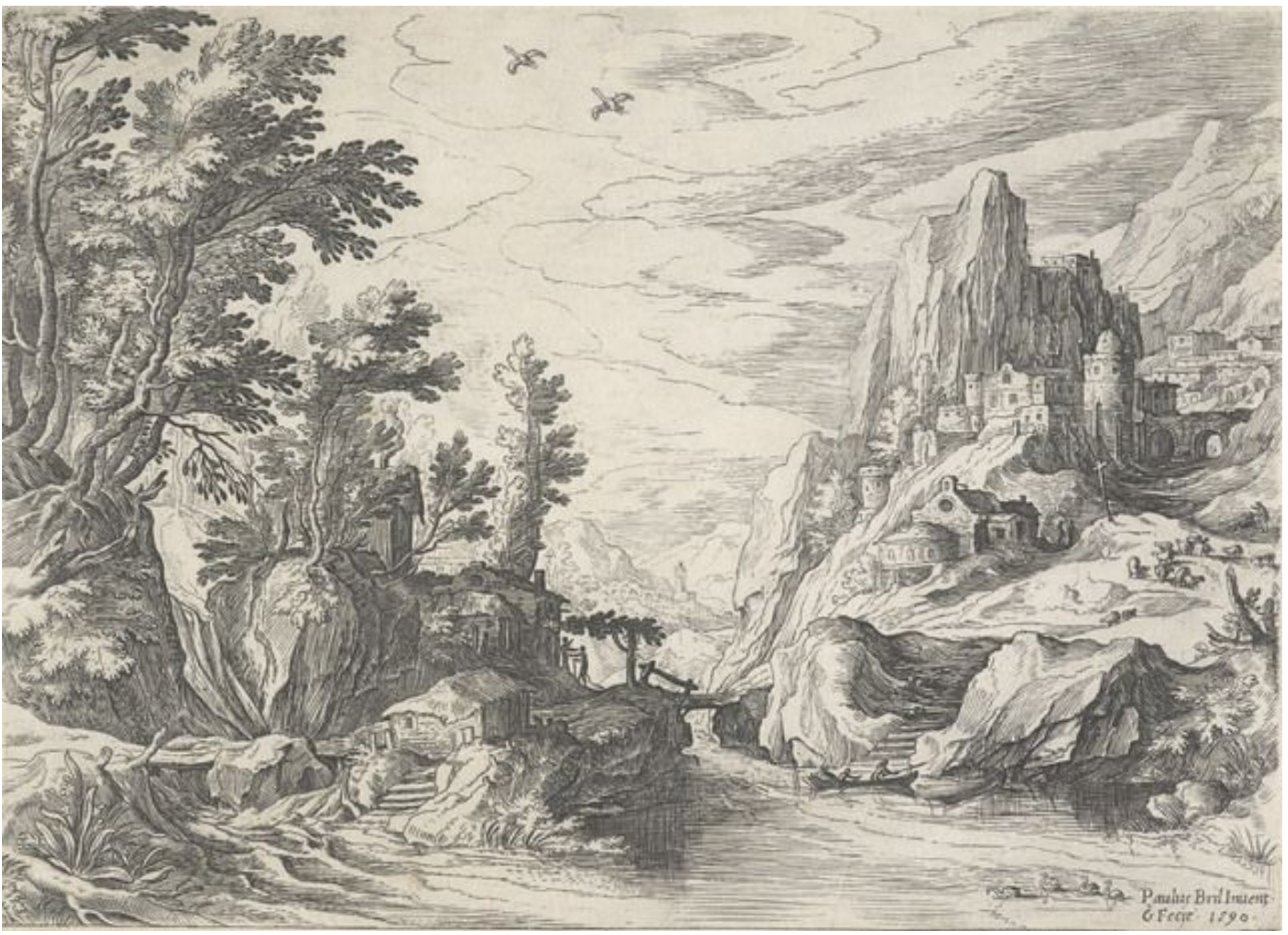

Fig. 35: Paulus Bril's River landscape with a shepherd on a hill to the right, 1590, etching, 199 x 277 mm (Support 201 x 279 mm), Museum of New Zealand Te Papa Tongarewa, Wellington. 


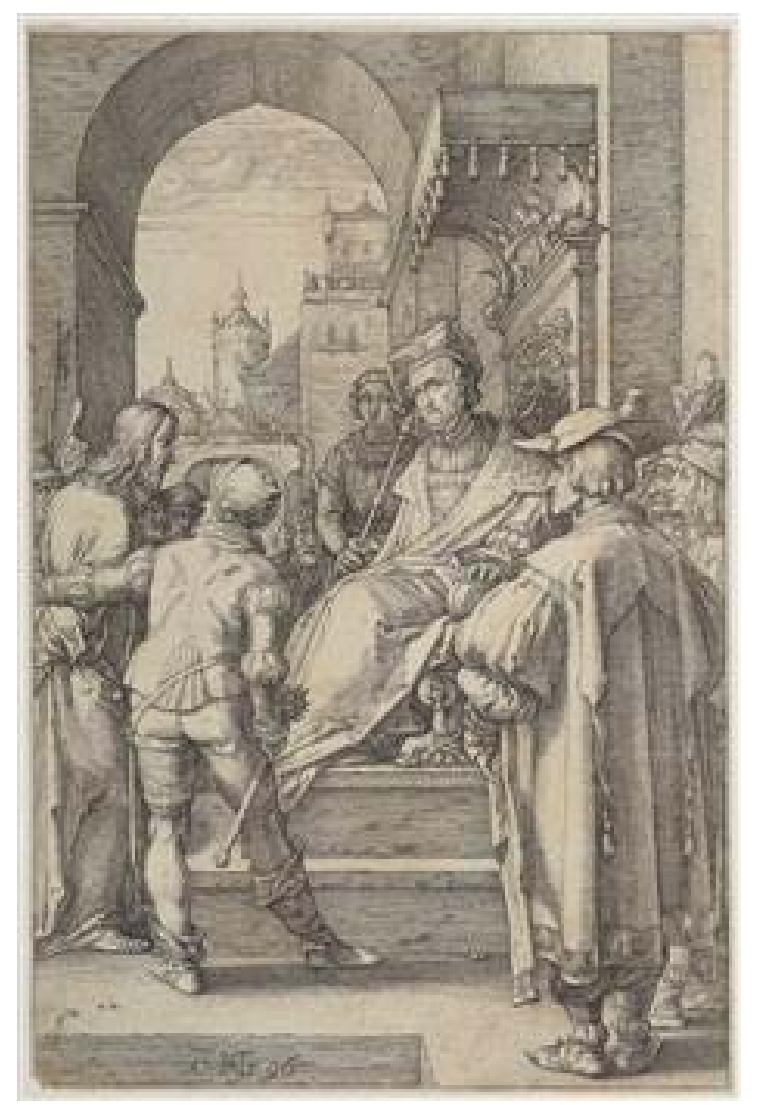

Fig. 36: Hendrick Goltzius, Christ before Pilate, 1596, engraving, 197 x 130 mm (Support 200 x 132 mm), Museum of New Zealand Te Papa Tongarewa, Wellington.

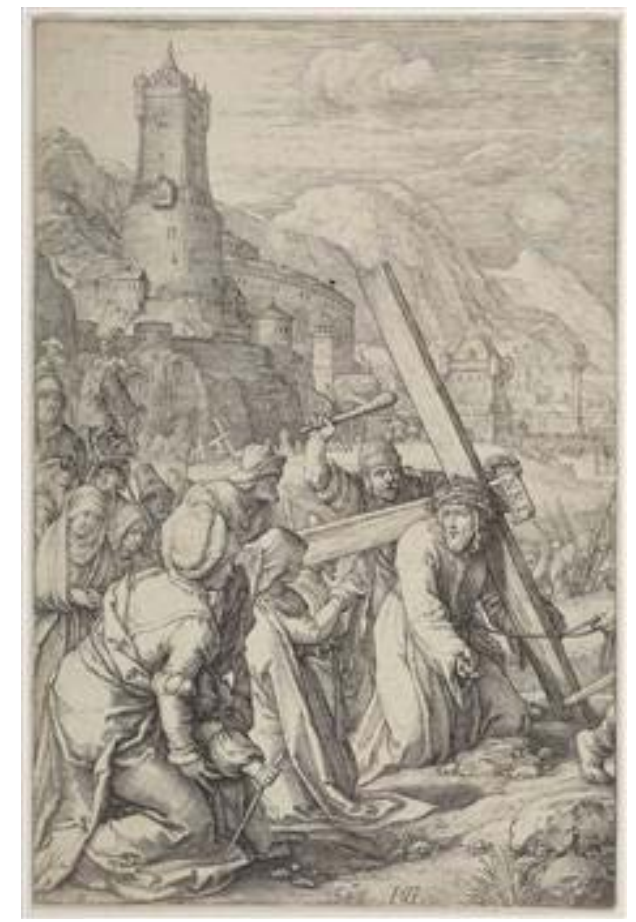

Fig. 37: Hendrick Goltzius, The Bearing of the Cross, 1596-98, engraving, 197 x $130 \mathrm{~mm}$ (Support 200 x 132 mm), Museum of New Zealand Te Papa Tongarewa, Wellington. 


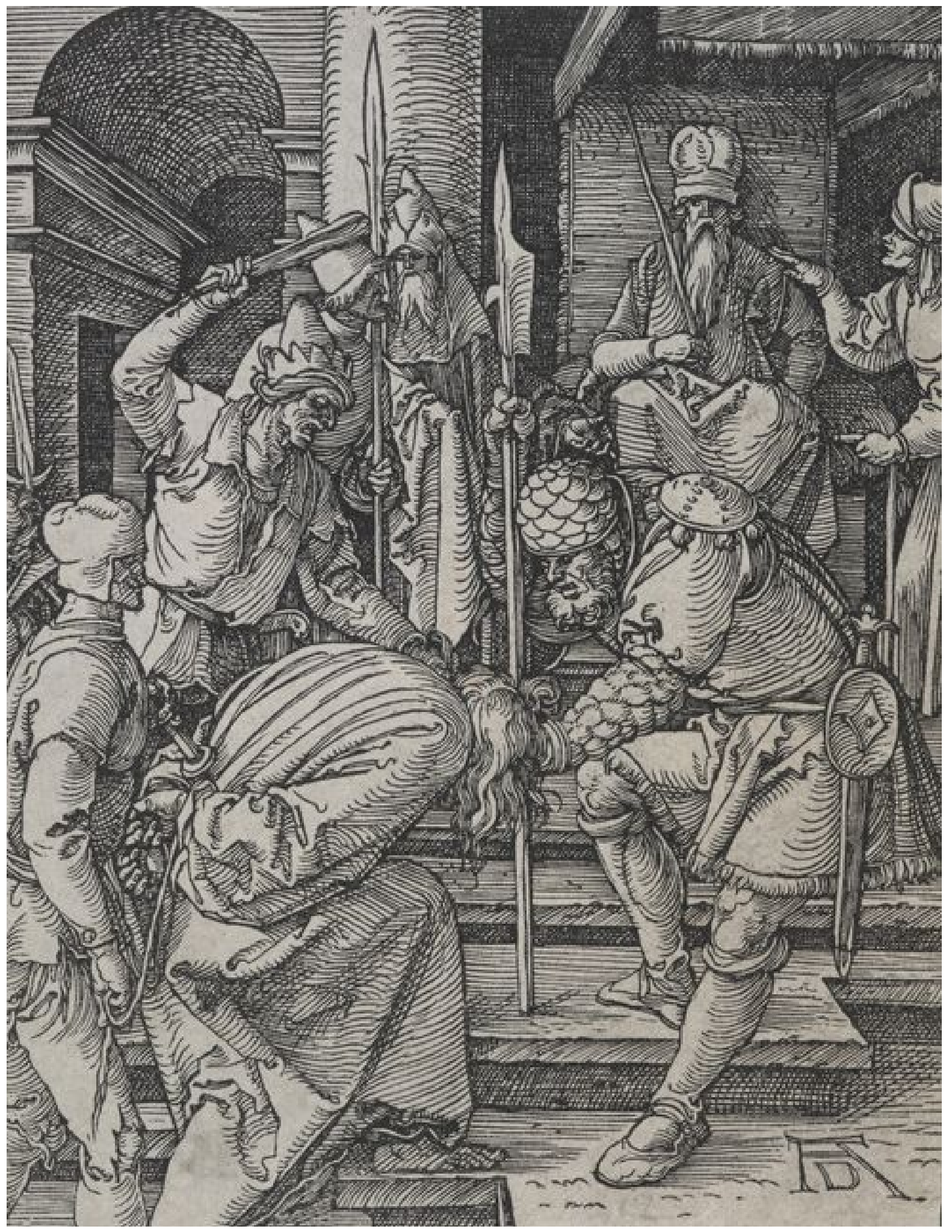

Fig. 38: Albrecht Dürer, Christ before Annas, 1508-1509, woodcut, 126 x 97 mm (Support 126 x $97 \mathrm{~mm}$ ), Museum of New Zealand Te Papa Tongarewa, Wellington. 


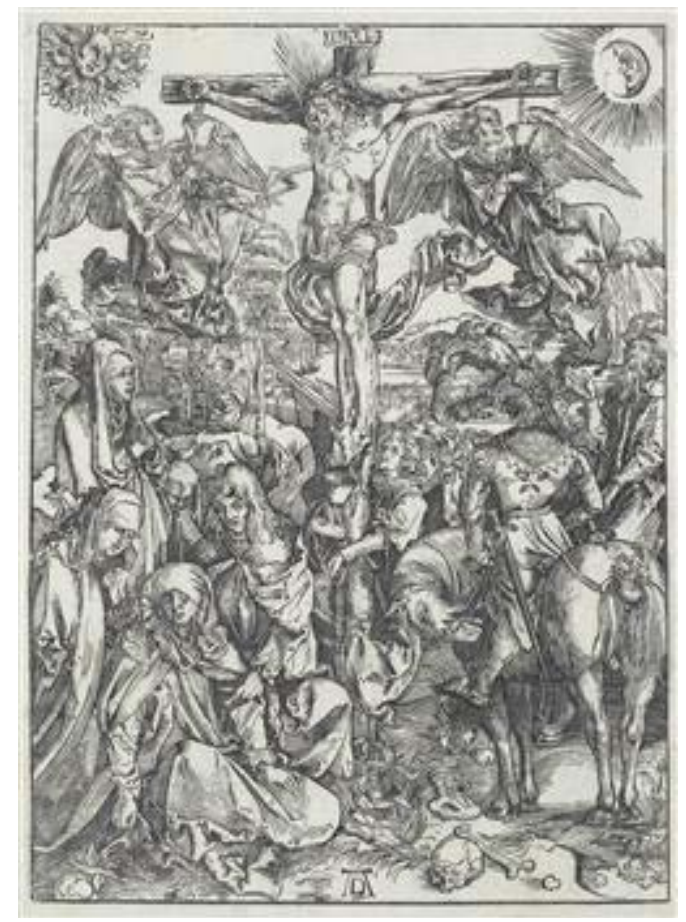

Fig. 39: Albrecht Dürer, Crucifixion, from Large Passion, 1497-98, woodcut, 388 x 278 mm (Support 466 x 342 mm), Museum of New Zealand Te Papa Tongarewa, Wellington.

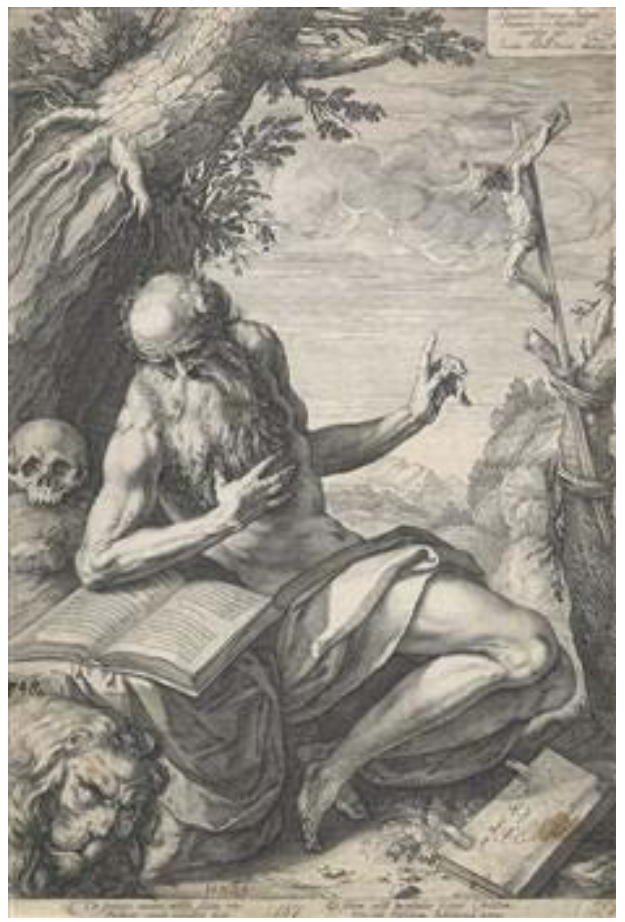

Fig. 40: Hendrick Goltzius (after Jacopo Palma), St. Jerome in the Desert, 1596, engraving, 404 x 278 mm (Support 406 x 280 mm), Museum of New Zealand Te Papa Tongarewa, Wellington. 


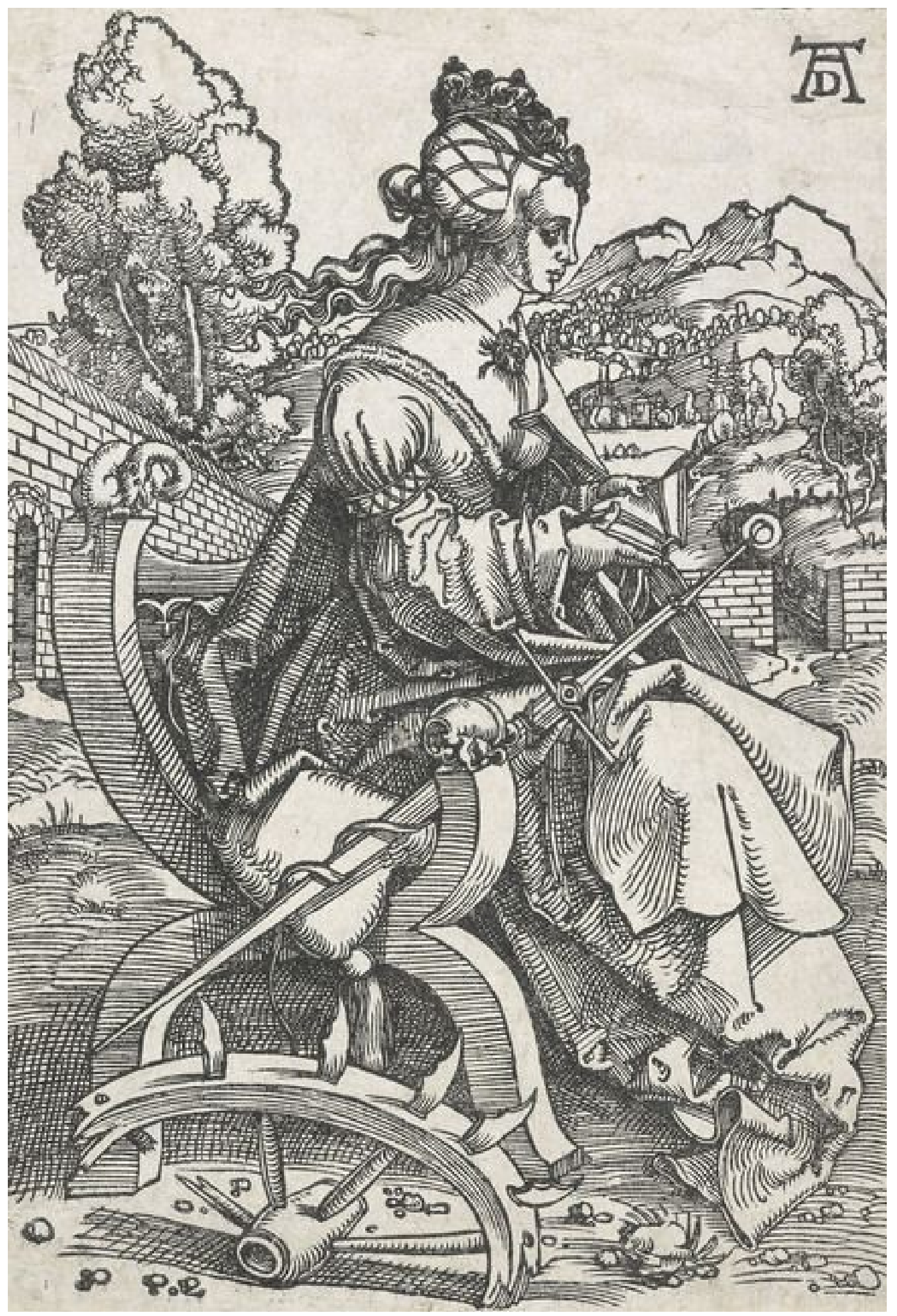

Fig. 41: Hans Baldung, St. Catherine, 1505-07, woodcut, 236 x 161 mm (Support 236 x 161 $\mathrm{mm}$ ), Museum of New Zealand Te Papa Tongarewa, Wellington. 


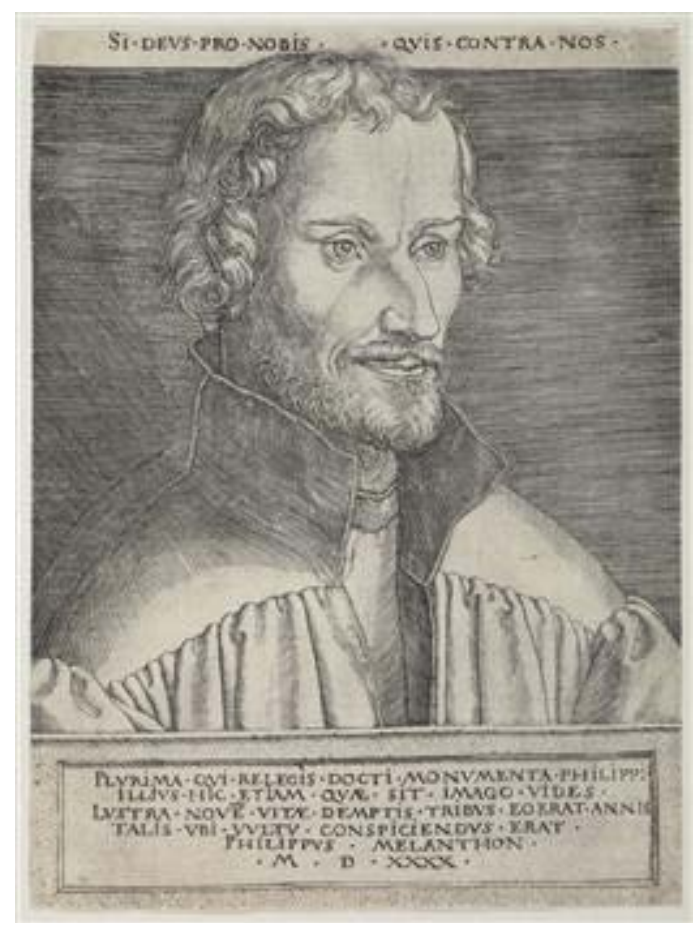

Fig. 42: Heinrich Aldegrever (after Lucas Cranach), Philip Melanchthon, 1540, engraving, 169 x 126 mm (Support 169 x 126 mm), Museum of New Zealand Te Papa Tongarewa, Wellington.
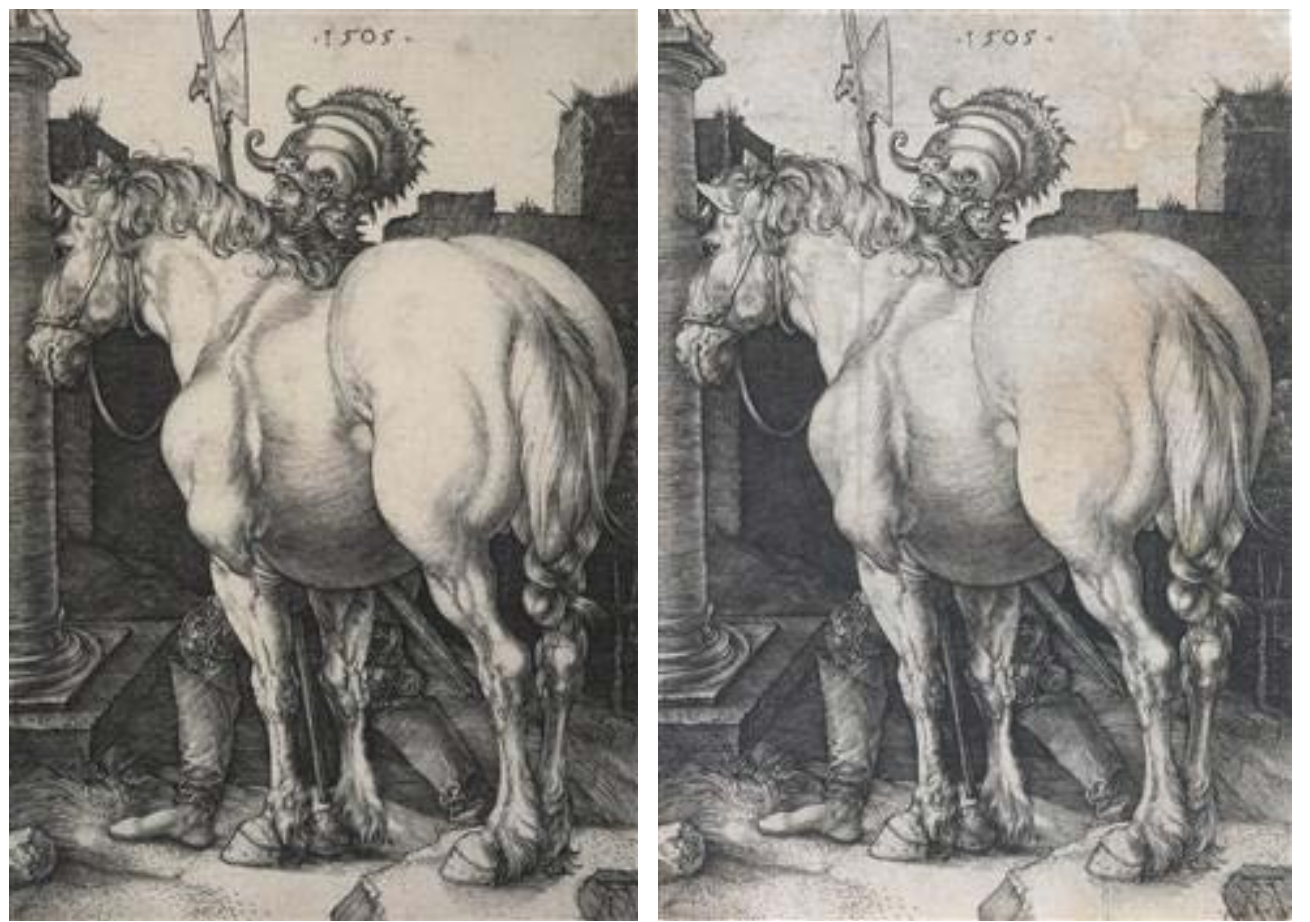

Fig. 43: Albrecht Dürer, The Large horse, 1505, engraving, 165 x 116 mm (Support $165 \mathrm{x}$ 116 mm), 1962-0001-9, Museum of New Zealand Te Papa Tongarewa, Wellington.

Fig. 44: Albrecht Dürer, The Large horse, 1505, engraving, 165 x 116 mm (Support 165 x 116 mm), 1869-0001-126, Museum of New Zealand Te Papa Tongarewa, Wellington. 

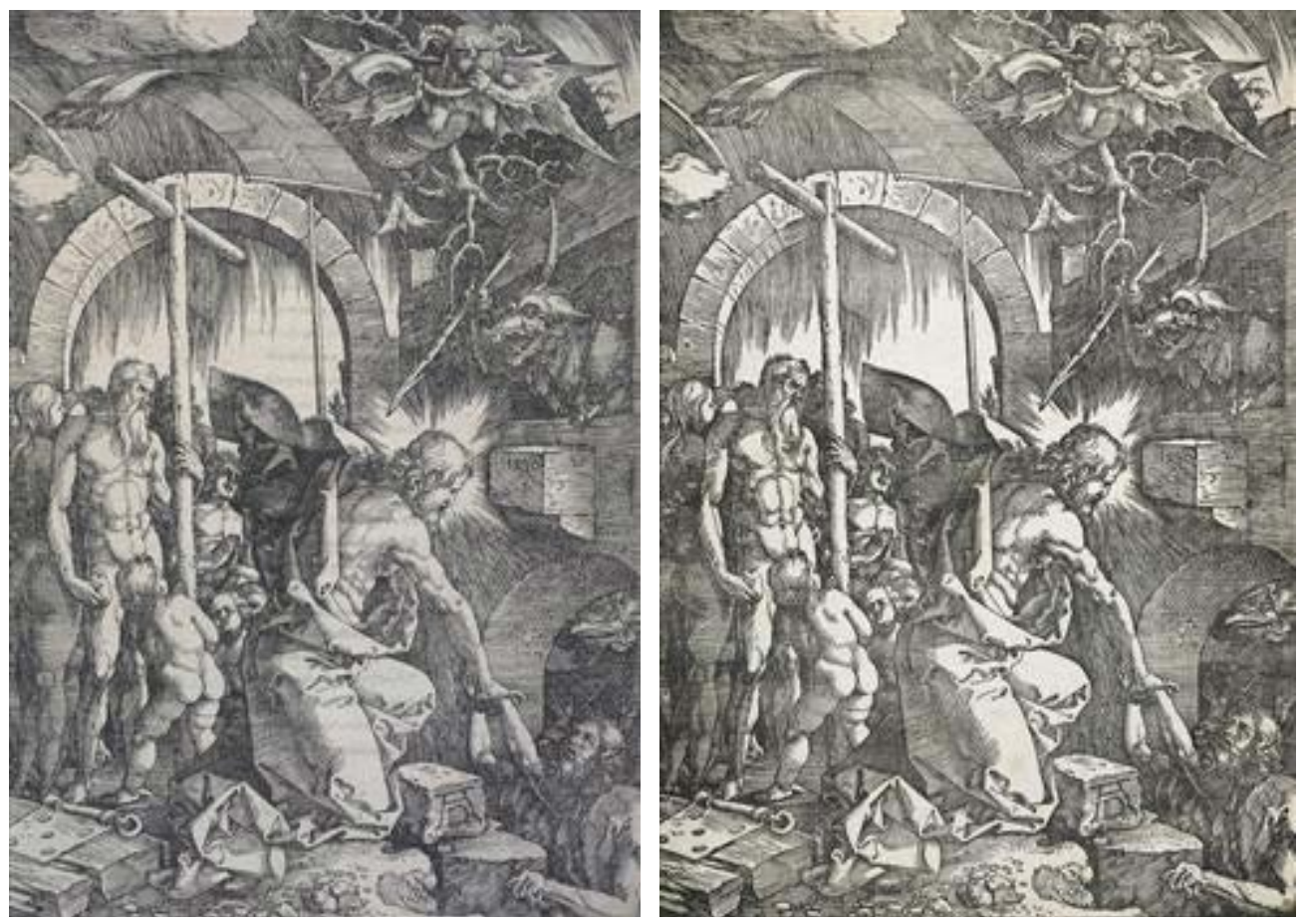

Fig. 45: Albrecht Dürer, Christ in limbo, from the Large Passion, 1510, woodcut, 396 x 281 mm (Support 400 x 285 mm), 1966-0005-2, Museum of New Zealand Te Papa Tongarewa, Wellington.

Fig. 45: Albrecht Dürer, Christ in limbo, from the Large Passion, 1510, woodcut, 397 x 278 mm (Support 397 x 278 mm), 1869-0001-132, Museum of New Zealand Te Papa Tongarewa, Wellington.

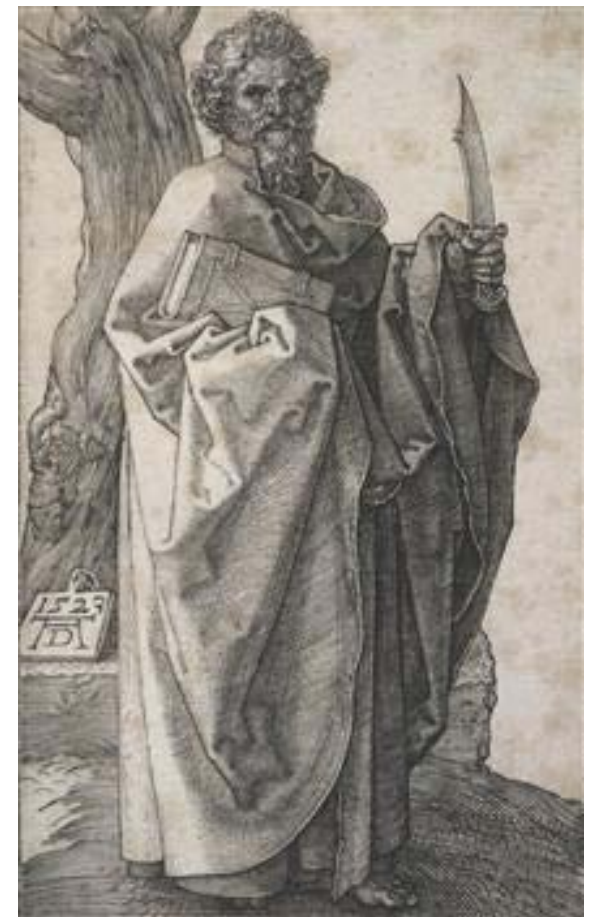

Fig. 47: Albrecht Dürer, St. Bartholomew, 1523, engraving, 122 x 76 mm (Support 122 x 76 $\mathrm{mm})$, Museum of New Zealand Te Papa Tongarewa, Wellington. 


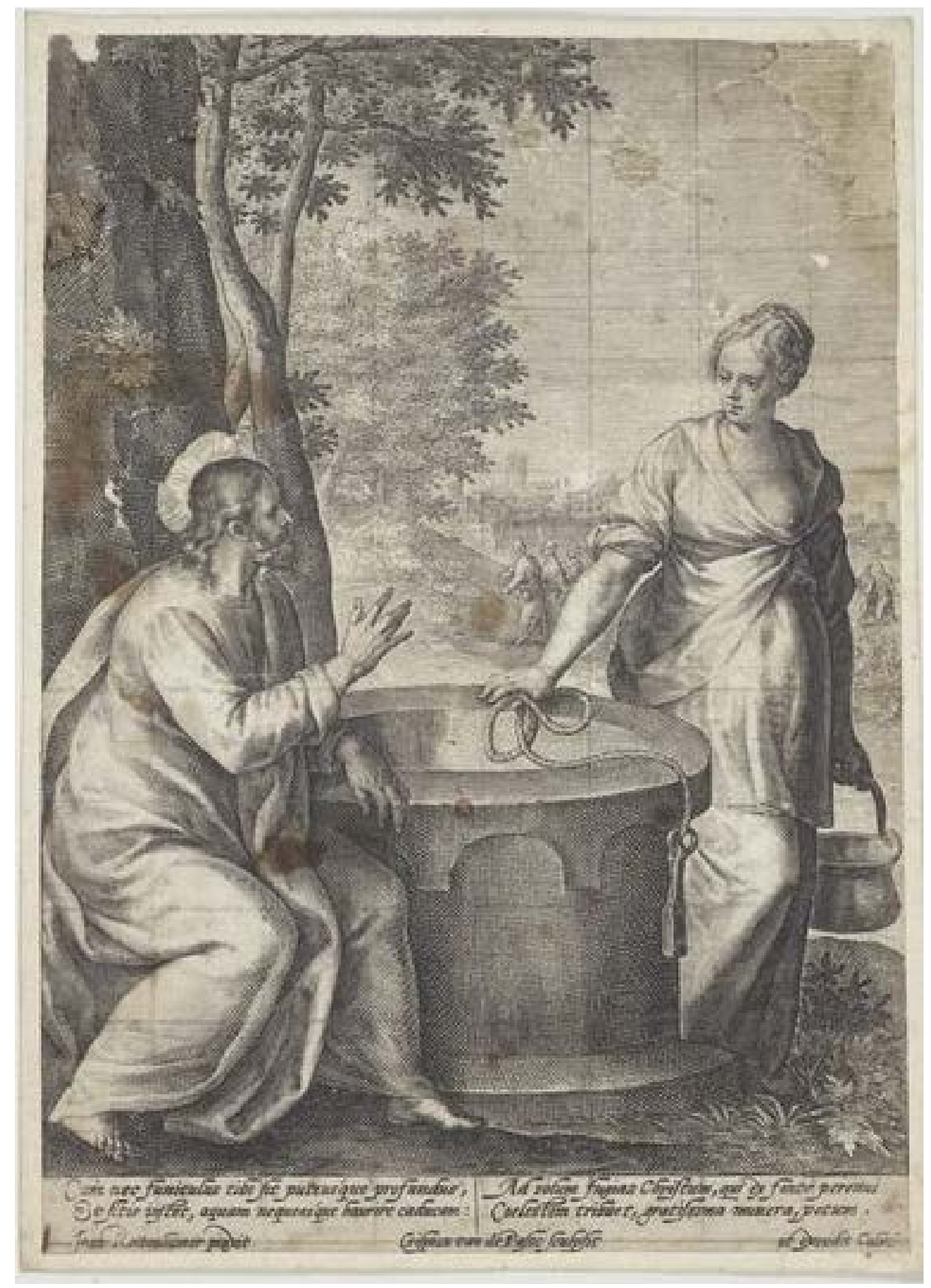

Fig. 48: Crispijn de Passe the Elder, Christ and the woman of Samaria, c. 1600, engraving, Museum of New Zealand Te Papa Tongarewa, Wellington. 

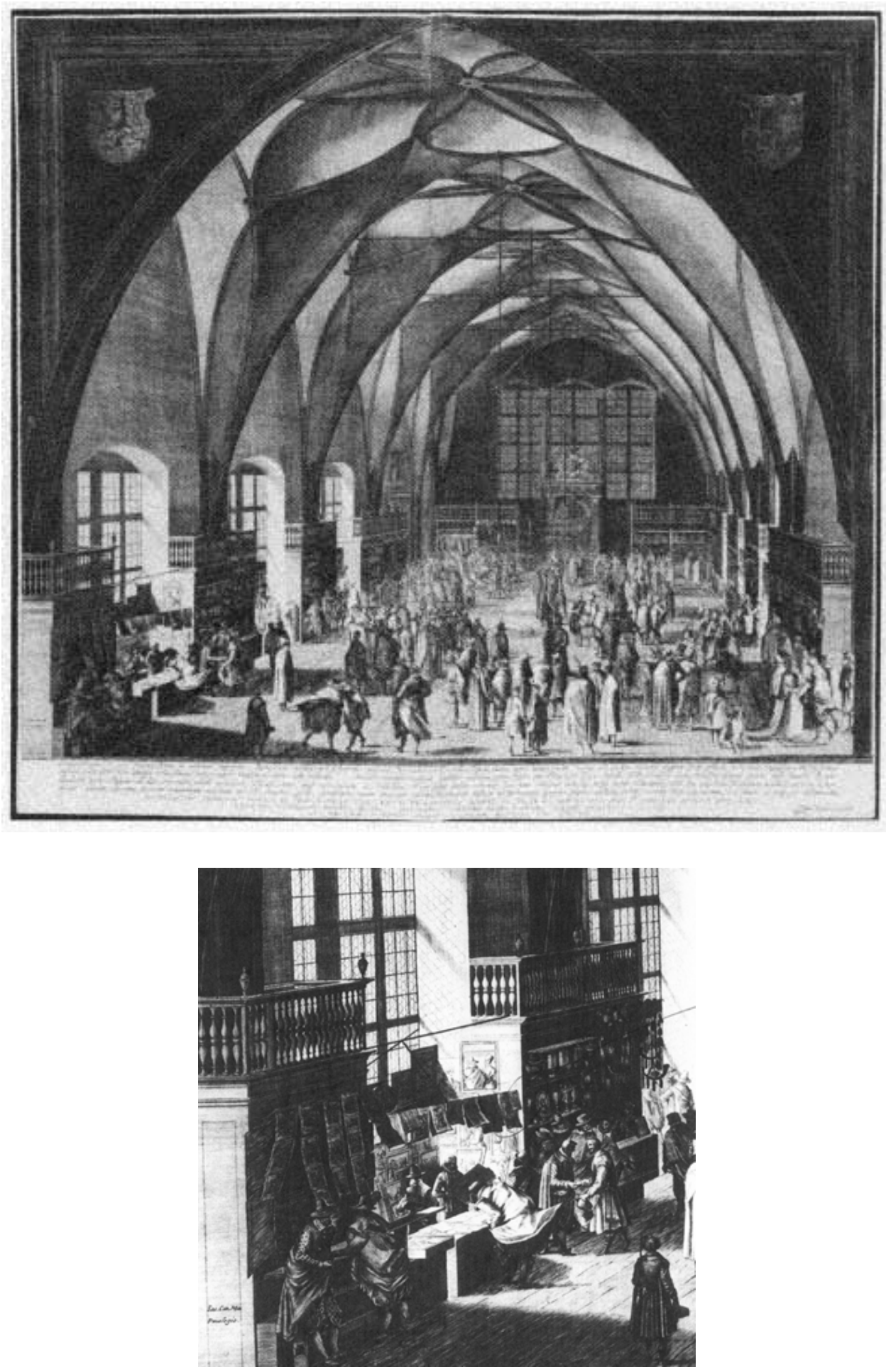

Fig. 49: Aegidius Sadeler, The Great Hall of the Hradshin Imperial Castle, detail, 1607, engraving, 573 x 301 mm, Rijksmuseum, Amsterdam. 


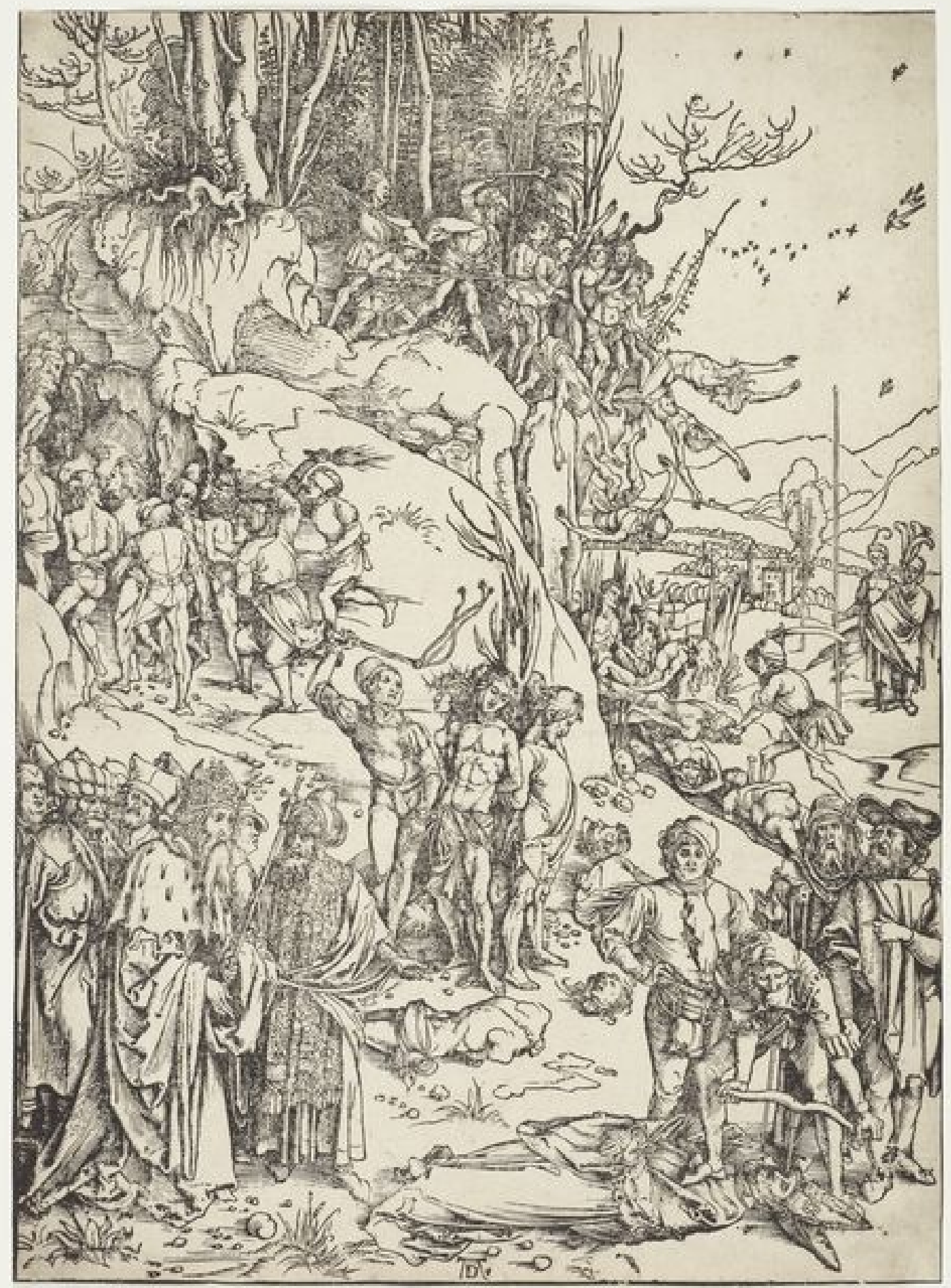

Fig. 50: Albrecht Dürer, The martyrdom of the ten thousand, 1497-98, woodcut, 387 x 281 mm (Support 387 x 281 mm), Museum of New Zealand Te Papa Tongarewa, Wellington. 


\section{Bibliography}

\section{Unpublished Sources}

\section{Alexander Turnbull Library, Wellington}

MS-Papers-1068-04 - Addresses

MS-Papers-1068-15 - Tributes and newspaper clippings

MS-Papers-1068-16 - Newspaper clippings

MS-Papers-1068-17 - Album of newspaper clippings

MS-Papers-1068-18 - Albums of newspaper clippings and other material

MS-Papers-1068-23 - Notes and newspaper clippings - National Art Gallery

MS-Papers-1068-26 - Miscellaneous personal papers

MS-Papers-3120 - Monrad, Ditlev Gothard, 1811-1887: Letters to Fredericksen

MS-Papers-10927 - Petersen, Bodil, fl 1978: Papers relating to Monrad family and Danish Inner Mission

\section{Archives New Zealand, Wellington}

IA/1/3008/158/172 - Miscellaneous - Etchings and engravings - Bishop Monrad collection

\section{Te Papa Archives, Wellington}

MU000003, box 5, item 11 - Gifts, 1937-53

MU000004, box 23, item 2 - Bequests, Trusts and General Correspondence, 1980-84

MU000007, box 8, item 19 - Ilott and Wright exhibition, 1966

MU000008, box 4, item 1 - Monrad Collection of Engravings, 1956-60

MU000009, box 13, item 1 - Ilott Collection, 1964-67

MU000009, box 13, item 2 - Ilott Collection, 1950-64

MU000010, box 5, item 5 - Ilott Collection, 1955-77

MU000013, box 1, item 1, file 666 - M - Outward Letter: Monrad, Bishop: Page 615 
MU000013, box 1, item 1, file 835 - M - Outward Letter: Lean, Mr (Re: Bishop Monrad Collection): Page 747

MU000013, box 1, item 2, file 256 - C - Outward Letter: Colonial Secretary 1871; Page 170,1871

MU000044, box 1, item 2 - Ilott Collection, 1961-82

MU000044, box 2, item 6 - Sir John Ilott and his times - queries and responses, 1987

MU000044, box 2, item 11 - Bishop Monrad Collection, 1937-60

\section{Te Papa Library Files, Wellington}

Collections - Monrad

Collections - Ilott

Artists - Albrecht Dürer

\section{Te Papa Print Room, Wellington}

Craddock and Barnard catalogues with Ilott's annotations:

Craddock and Barnard, Engravings \& Etchings (Fifteenth to Eighteenth Centuries), no. 113, London, 1966/70

no. 115, London, 1967

Engravings \& Etchings (Fifteenth to Eighteenth Centuries),

Engravings \& Etchings (Fifteenth to Eighteenth Centuries), no. 117, London, 1968/69

Engravings \& Etchings (Fifteenth to Eighteenth Centuries), no. 119, London, 1969/70

Ilott Index Cards

Acquisition Proposal 3088 (29-Apr-2009), recommended by Victoria Robson, supported by Tony Mackle, authorised by Lesley Cobb 


\section{Books and Book Chapters}

100 master prints from the Ilott Collection, designed and compiled by G. Packwood and C. Quirck, Wellington: National Art Gallery, 1974

Ames-Lewis, Francis, The intellectual life of the early Renaissance artist, New Haven and London: Yale University Press, 2000

Baekeland, Frederick, 'Psychological aspects of art collecting', in Susan Pearce (ed.), Interpreting objects and collections, London; New York: Routledge, 1994, pp. 205-219

Baker, Christopher, Caroline Elam and Genevieve Warwick (eds.), Collecting prints and drawings in Europe, c. 1500-1750, Burlington: Ashgate, 2003

Bartrum, Giulia, German Renaissance prints, 1490-1550, London: British Museum Press, 1995

Bartsch, Adam von, Anleitung zur Kupferstichkunde, Vienna: J. B, Wallishausser, 1821 Le Peintre-graveur, 21 volumes, Vienna: J. V. Degen, 1803-21

Bender, Henning and Birgit Larsen (eds.), Danish emigration to New Zealand, Aalborg (Denmark): Danes Worldwide Archives, 1990

Bosse, Abraham, Sentimens sur la distinction des diverses manières de peinture, dessein et graveure, et des originaux d'avec leurs copies, Paris: Chez l'auteur/published by the author, 1649

Clayton, Muriel, The print collector, London: Herbert Jenkins Limited, 1929

Cycleback, David Rudd, Judging the authenticity of prints by the Masters, Lulu.com, 2007

Damsgaard, Nina and Signe Jacobsen (eds.), D. G. Monrad: en kunstsamler i 1800-tallet, Vejle (Denmark): Vejle Kunstmuseum, Nivå (Denmark): Nivaagaards malerisamling, 1992

Donson, Theodore B., Prints and the print market: a handbook for buyers, collectors, and connoisseurs, New York: Thomas Y. Crowell, 1977

Drees, Clayton J. (ed.), The late medieval age of crisis and renewal, 1300-1500: a biographical dictionary, Westport: Greenwood Publishing Group, 2001

Evelyn, John, Sculptura: or, the history and art of chalcography, and engraving in copper, $2^{\text {nd }}$ edition, London: J. Payne, 1755 [1662] and Samuel Pepys, Extracts from the diaries and correspondence of John Evelyn and Samuel Pepys relating to engraving, London: Ellis, 1915

Friedländer, Max J., Lucas van Leyden, Leipzig: Klinkhardt \& Biermann, 1925 
Gaier, Ulrich, Studien zu Sebastian Brants Narrenschiff, Tübingen: Max Niemeyer, 1966

Gilpin, William, An essay upon prints, London: J. Robson, 1768

Goddard, Stephen H. (ed.), The World in miniature: engravings by the German little masters, 1500-1550, Kansas: Spencer Museum of Art, University of Kansas, 1988

Grebe, Anja, Albrecht Dürer: Künstler, Werk und Zeit, Darmstadt: WBG (Wissenschaftliche Buchgessellschaft), 2006

Griffiths, Antony, 'John Evelyn and the print', in Frances Harris and Michael Hunter (eds.), John Evelyn and his milieu, London: The British Library, 2003, pp. 95114

(ed.), Landmarks in print collecting: connoisseurs and donors at the British Museum since 1753, London: British Museum Press, 1996

Heineken, Carl Heinrich von, Idée générale d'une collection complette d'estampes: avec une dissertation sur l'origine de la gravure et sur les premiers livres d'images, Leipzig and Vienna: Jean Paul Kraus, 1771

Hind, Arthur M., A history of engraving and etching: from the 15th century to the year 1914, $3^{\text {rd }}$ edition, New York: Dover Publications, 1963

Howard, Jeremy (ed.), Colnaghi: the history, London: Colnaghi, 2010

Ilott, Jack, Creating customers: the story of Ilott Advertising, New Zealand, 1892-1982, Auckland: Ray Richards Publisher, 1985

The Ilott Story, Wellington: Mallinson Rendel , 1993

Jacobowitz, Ellen S., and Stephanie Loeb Stepanek, The prints of Lucas van Leyden and his contemporaries, Washington: National Gallery of Art, 1983

James, Carlo (et al), Old master prints and drawings: a guide to preservation and conservation, Marjorie B. Cohn (trans. and ed.), Amsterdam: Amsterdam University Press, 1997

Kisler, Mary, Angels and aristocrats: early European art in New Zealand public collections, Auckland: Auckland Art Gallery Toi o Tāmaki, 2010

Koschatzky, Walter, 'Adam von Bartsch: an introduction to his life and work', in Walter L. Strauss (ed.), The illustrated Bartsch, New York: Abaris Books, 1978, pp. vii-xvii

Laing, Samuel, Observations on the social and political state of Denmark and the duchies of Sleswick and Holstein in 1851: being the third series of the notes of a traveller on the social and political state European people, London: Longman, Brown, Green and Longsmans, 1852 
Landau, David and Peter Parshall, The Renaissance print: ca. 1470-1550, New Haven: Yale University Press, 1993

Lehrs, Max, Martin Schongauer: the complete engravings: a catalogue raisonné, San Francisco: Alan Wofsy Fine Arts, 2005 [1925]

Levis, Howard C., A descriptive bibliography of the most important books in the English language relating to the art and history of engraving and the collecting of prints, Folkestone: Dawsons, 1974 [1912]

Longhi, Giuseppe, La Calcografia propriamente detta ossia l'Arte d'Incidere in Rame coll'Acqua-forte, col Bulino e colla Punta ... Volume I, concernent la Teoria dell'arte, Milano: Stamperia Reale, 1830

Maberly, Joseph, The print collector: an introduction to the knowledge necessary for forming a collection of ancient prints, London: Saunders and Otley, 1844

Macfarlane, Ian (ed.), Bishop Monrad in Aotearoa: Ditlev Gothard Monrad's life and his legacy to New Zealand, Wellington, N.Z.: Karere Publications, 2011

Maskill, David, 'The Harold Wright Collection at Te Papa', in Adam Art Gallery, Before addled art: the graphic art of Lionel Lindsay, Wellington: Adam Art Gallery, 2003, pp. 5-6

McAloon, William (ed.), Art at Te Papa, Wellington: Te Papa Press, 2009

McDonald, Mark P., Ferdinand Columbus: Renaissance Collector (1488-1539), London: British Museum Press, 2005

McKellar, Suzanne, Our Ilott family history, Chorleywood, Hertfordshire: S. McKellar, 2003

Medieval woodcut illustrations: city views and decorations from "The Nuremberg chronicle", selected and arranged by Carol Belanger Grafton, Mineola: Dover Publications, 1999

Mielke, Ursula (compiled by), Heinrich Aldegrever, Rotterdam: Sound \& Vision Interactive, 1998

Monrad, Kasper, The golden age of Danish painting, New York: Hudson Hills Press in association with Los Angeles County Museum of Art, 1993

Museum of Fine Arts, Boston, Albrecht Dürer: Master Printmaker, New York: Hacker Art Books, 1988

Museum of New Zealand, An agenda for scholarship: scholarship and research in the Museum of New Zealand Te Papa Tongarewa, Wellington: Board of the Museum of New Zealand, 1994 
National Art Gallery, Face to face: a survey of artists' prints, Wellington: National Art Gallery, 1986

The Harold Wright Collection of prints and drawings, Wellington: National Art Gallery, Consolidated Press Holdings, 1966

The Ilott Collection of original prints by old and modern masters, Wellington: National Art Gallery, 1966

Packwood, G. and C. Quirk (designed and compiled by), 100 master prints from the Ilott Collection, Wellington: National Art Gallery, 1974

Parshall, Peter, 'The Print Collection of Ferdinand, Archduke of Tyrol', in Jahrbuch der Kunsthistorischen Sammlungen in Wien, Volume 78, Vienna: Anton Schroll and Co., 1982, pp. 139-184

Petersen, G. C., D. G. Monrad: scholar, statesman, priest and New Zealand pioneer and his New Zealand descendants, Levin: Kerslake, Billens and Humphrey, 1965

Piles, Roger de, 'Of the Usefulness and Use of Prints', in The Art of Painting, with the Lives and Characters of above 300 of the Most Eminent Painters, 3rd edition, London: T. Payne and Sons, 1754 [1699], pp. 49-60

Pon, Lisa, Raphael, Dürer, and Marcantonio Raimond: copying and the Italian Renaissance print, New Haven: Yale University Press, 2004

Robinson, William W., “"This Passion for Prints”: Collecting and Connoisseurship in Northern Europe during the Seventeenth Century', in Clifford S. Ackley (ed.), Printmaking in the Age of Rembrandt, Boston: Museum of Fine Arts, 1981, pp. xxvii-xlviii

Rying, Bent (ed.), Denmark: an official handbook, $14^{\text {th }}$ edition, Copenhagen: Krak, 1970

Sandrart, Joachim von, Teutsche Academie de Bau-, Bild- und Mahlerey-kunst von 1675: leben der beruhmten Maler, Bildhauer und Baumeister, Farnborough: Gregg, 1971 [1675-1680]

Schioldann-Nielsen, Johan, The life of D.G. Monrad, 1811-1887: manic-depressive disorder and political leadership, Odense (Denmark): Odense University Press, 1988

Schlosser, Julius von, Die Kunst- und Wunderkammern der Spätrenaissance, Leipzig: Klinhardt und Biermann, 1908

Schmidt, Suzanne Karr, Altered and Adorned: using Renaissance prints in daily life, The Art Institute of Chicago, New Haven and London: Yale University Press, 2011

Sculptura historico-technica: or, the history and art of engraving, extracted from Baldinucci, Florent le Comte, Fairthorne, the Abecedario pittorico, and other 
authors, $4^{\text {th }}$ edition, London: J. Marks, 1770 [1747]

Sellink, Manfred (compiled by), Cornelis Cort, Rotterdam: Sound \& Vision Publishers, in co-operation with the Rijksprentenkabinet, Rijksmuseum, Amsterdam, 2000

Slater, J. Herbert, Engravings and their value: a guide for the print collector, $3^{\text {rd }}$ edition, London: L. Upcott Gill, 1900

Smith, Jeffrey Chipps, Nuremberg: a Renaissance city, 1500-1618, Austin: University of Texas Press, 1983

Snyder, James, Northern Renaissance Art: painting, sculpture, the graphic arts from 1350 to 1575, New York: Harry N. Abrams, 1985

Stavnstrup, P., D. G. Monrad: Politiker og Gejstlig, Copenhagen: Berlingske Forlag, 1948

Stewart, Alison G., Before Bruegel: Sebald Beham and the origins of peasant festival imagery, Hampshire; Burlington: Ashgate, 2008

Strauss, Walter L. (ed.), Hendrik Goltzius, 1558-1617: the complete engravings and woodcuts, New York: Abaris Books, 1977

Strutt, Joseph, A biographical dictionary: containing an historical account of all the engravers, from the earliest period of the art of engraving to the present time; and a short list of their most esteemed works, London: Robert Faulder, 1785

Talbot, Charles W. (ed.), Prints and drawings of the Danube School: an exhibition of South German and Austrian graphic art of 1500 to 1560, New Haven: Yale University Press, 1969

Taylor, Rev. Richard, The past and present of New Zealand: with its prospects for the future, London: William Macintosh; Wanganui: Henry Ireson Jones, 1868

Vasari, Giorgio, Le vite dei più eccellenti pittori, scultori e architetti, Rome: Newton Compton editori, 2010 [1568]

Whitman, Alfred, Whitman's Print-Collector's Handbook, 6th edition, Malcolm C. Salaman (ed.), London: G. Bell and Sons, Ltd, 1921 [1901]

Willshire, Willian Hughes, An introduction to the study and collection of ancient prints, 2nd edition (revised and enlarged), London: Ellis and White, 1877

Wilson, Adrian, The making of the Nuremberg Chronicle, Amsterdam: A. Asher \& Co., 1976

Winzinger, Franz, Albrecht Altdorfer: Graphik: Holzchnitte, Kupferstiche, Radierungen, München : Piper, 1963

Zdanowicz, Irena (ed.), Albrecht Dürer in the collection of the National Gallery of Victoria, Melbourne: National Gallery of Victoria, 1994 
Zigrosser, Carl and Christa M. Gaehde, A guide to the collecting and care of original prints, New York: Crown Publishers, 1965 


\section{Articles and Websites}

Andersson, Christiane, 'Baldung, Hans', Grove Art Online. Oxford Art Online, VUW Lib. http://www.oxfordartonline.com/subscriber/article/grove/art/T005901 (accessed November 16, 2011).

Bergmann, Rosemarie, 'Aldegrever, Heinrich', Grove Art Online. Oxford Art Online, VUW Lib., http://www.oxfordartonline.com/subscriber/article/grove/ art/T001636, (accessed November 16, 2011)

Boorsch, Suzanne and Nadine M. Orenstein, 'The Print in the North: The Age of Albrecht Dürer and Lucas van Leyden', The Metropolitan Museum of Art Bulletin, New Series, 54 (4), 1997, pp. 1+13-60, JSTOR, VUW Lib. http://www.jstor.org, (accessed 18 January 2012)

Buchanan, Iain, 'Dürer and Abraham Ortelius’, The Burlington Magazine, 124 (957), 1982, pp. 734-741, JSTOR, VUW Lib. http://www.jstor.org, (accessed 8 January 2011)

Bury, Michael, 'The taste for prints in Italy to c. 1600', Print Quarterly, 2 (1), 1985, pp. $12-26$

Campbell Hutchison, Jane, 'Suavius, Lambert', Grove Art Online. Oxford Art Online, VUW Lib., http://www.oxfordartonline.com/subscriber/article/grove/art/ T082158 (accessed November 16, 2011).

Cornelis, Bart and Jan Piet Filedt Kok, 'The taste for Lucas van Leyden prints', Simiolus: Netherlands Quarterly for the History of Art, 26 (1/2), 1998, pp. 18-86, JSTOR, VUW Lib. http://www.jstor.org, (accessed 8 January 2011)

Courtright, Nicola, 'Bril', Grove Art Online. Oxford Art Online, VUW Lib. http://www.oxfordartonline.com/subscriber/article/grove/art/T011341pg2 (accessed November 16, 2011).

Davis, Mark, 'John Eaton Hardwick-Smith’, Psychiatric Bulletin, 22, 1998, p. 191, http://pb.rcpsych.org/content/22/3/191.full.pdf (accessed 8 September 2011)

Devisscher, Hans and Timothy Riggs, 'Cock', Grove Art Online. Oxford Art Online, VUW Lib., http://www.oxfordartonline.com/subscriber/article/grove/art/T018357pg3 (accessed November 16, 2011).

'European Master Prints: The founding gift of Bishop Monrad', http://www.tepapa.govt.nz/WhatsOn/exhibitions/Pages/EuropeanMasterPrints thefoundinggiftofBishopMonrad.aspx, (accessed 2 October 2011)

Fulton, Torbjörn, 'Binck, Jakob’, Grove Art Online. Oxford Art Online, VUW Lib. http://www.oxfordartonline.com/subscriber/article/grove/art/T008916 (accessed November 16, 2011).

Gmelin, Hans Georg, 'Pencz, Georg', Grove Art Online. Oxford Art Online, VUW Lib. http://www.oxfordartonline.com/subscriber/article/grove/art/T066164, 
(accessed November 16, 2011).

Grave, Johannes, 'Ideal and History: Johann Wolfgang Goethe's collection of prints and drawings', Artibus et Historiae, 27 (53), 2006, pp. 175-186, JSTOR, VUW Lib. http://www.jstor.org, (accessed 8 January 2011)

Griffiths, Antony, 'Print collecting in Rome, Paris and London in the early eighteenth century’, Harvard University Art Museums Bulletin, 2 (3), 1994, pp. 37-58, JSTOR, VUW Lib. http://www.jstor.org, (accessed 8 January 2011)

Hajós, Elizabeth M., 'The concept of an engravings collection in the year 1565: Quicchelberg, Inscriptiones vel Tituli Theatri Amplissimi', The Art Bulletin, 40 (2), 1958, pp. 151-156, JSTOR, VUW Lib. http://www.jstor.org, (accessed 8 January 2011)

'Harold Beauchamp Trust Fund', http://collections.tepapa.govt.nz/theme.aspx?irn=630, (accessed 8 October 2011)

Heck, Christian, 'Schongauer', Grove Art Online. Oxford Art Online, VUW Lib. http://www.oxfordartonline.com/subscriber/article/grove/art/T076738pg1 (accessed 16 November, 2011).

Hedges, S. Blair, 'A method for dating early books and prints using image analysis', Proceedings: Mathematical, Physical and Engineering Sciences , 462 (2076), December 2006, pp. 3555-3573, JSTOR, VUW Lib. http://www.jstor.org, (accessed 8 January 2011)

Hind, A. M., 'Engravings and their states-I', The Burlington Magazine for Connoisseurs, 15 (73), April 1909, pp. 25-30, JSTOR, VUW Lib. http://www.jstor.org, (accessed 8 December 2011)

'Engravings and their states-II. States in actual life', The Burlington Magazine for Connoisseurs, 15 (77), August 1909, pp. 271-273+275-277+280283+285, JSTOR, VUW Lib. http://www.jstor.org, (accessed 8 December 2011)

'Interesting Wedding: Medical Families Hardwick-Smith - Kemp', Evening Post, Volume CXXVI, Issue 153, 2 December 1938, p. 16, http://paperspast.natlib.govt.nz/ cgi-bin/paperspast?a=d\&cl=search\&d=EP19381202.2.167.6\&srpos=3\&e=------10--1----0John+HardwickZz-Smith--, (accessed 24 August 2011)

Ivins, William M., Jr., 'Notes on three Dürer woodblocks', Metropolitan Museum Studies, 2 (1), 1929, pp. 102-111, JSTOR, VUW Lib. http://www.jstor.org, (accessed 8 January 2011)

Kok, J. P. Filedt, 'Lucas van Leyden', Grove Art Online, Oxford Art Online, VUW Lib., http://www.oxfordartonline.com/subscriber/article/grove/art/T052281, (accessed January 12, 2012)

Kusk, Grethe, et al., 'Denmark', Grove Art Online, Oxford Art Online, VUW Lib., http://www.oxfordartonline.com/subscriber/article/grove/art/T022158pg18, (accessed 25 August 2011) 
Landau, David, 'Vasari, Prints and Prejudice', Oxford Art Journal, 6 (1), 1983, pp. 3-10, JSTOR, VUW Lib. http://www.jstor.org, (accessed 8 January 2011)

Limouze, Dorothy, 'Aegidius Sadeler, Imperial Printmaker', Philadelphia Museum of Art Bulletin, 85 (362), 1989, pp. 1+3-24, JSTOR, VUW Lib. http://www.jstor.org, (accessed 18 January 2012)

Lugt, Frits, Les Marques de Collections de Dessins \& d'Estampes, Fondation Custodia, http://www.marquesdecollections.fr/

Maskill, David, 'Imperial lines: Harold Wright (1885-1961): printmaking and collecting at the end of empire: the Margaret Manion Lecture 2007', Melbourne Art Journal, (11-12), 2009, pp. 86-103

Mulders, Christine van, 'Galle’, Grove Art Online. Oxford Art Online, VUW Lib. http://www.oxfordartonline.com/subscriber/article/grove/art/T030495pg1 (accessed November 16, 2011).

Nenadic, Stana, 'Print collecting and popular culture in eighteenth-century Scotland', History: The Journal of the Historical Association, 82 (266), 1997, pp. 203-222

Parshall, Peter, 'Art and the theatre of knowledge: the origins of print collecting in Northern Europe', Harvard University Art Museums Bulletin, 2 (3), 1994, pp. 736, JSTOR, VUW Lib. http://www.jstor.org, (accessed 10 January 2011)

Prasse, Leona E., 'Engravings by Georg Pencz in the Museum Collection', The Bulletin of the Cleveland Museum of Art, 23 (4), 1936, pp. 50-53, JSTOR, VUW Lib. http://www.jstor.org, (accessed 15 January 2012)

Rauschenberg, Roy Anthony, 'Daniel Carl Solander: Naturalist on the "Endeavour"', Transactions of the American Philosophical Society, New Series, 58 (8), 1968, pp. 1-66, JSTOR, VUW Lib. http://www.jstor.org, (accessed 19 September 2011)

Reznicek, E. K. J., 'Goltzius, Hendrick’, Grove Art Online. Oxford Art Online, VUW Lib. http://www.oxfordartonline.com/subscriber/article/grove/art/T033104, (accessed November 16, 2011).

Riggs, Timothy, 'Cort, Cornelis', Grove Art Online. Oxford Art Online, VUW Lib., http://www.oxfordartonline.com/subscriber/article/grove/art/T019641, (accessed November 16, 2011)

Rowe, Margaret, 'Ward, Arthur Hugh - Biography', from the Dictionary of New Zealand Biography. Te Ara - the Encyclopedia of New Zealand, http://www.teara.govt.nz/en/biographies/5w8/1, (accessed 7 October 2011)

S., H. R., 'The "Little Masters" in the exhibition of early German prints', Museum of Fine Arts Bulletin, 11 (64), 1913, pp. 41-43, JSTOR, VUW Lib. http://www.jstor.org, (accessed 5 January 2012) 
'Sir Arthur Ward Award’, http://nzsap.org.nz/sap142.html, (accessed 6 September 2011)

'Sir John Ilott: 2010 Business Hall of Fame', in Stephanie Kane (ed.), The Lampstand, No. 20, 2010, pp.49, 53, http://www.wellington-college.school.nz/CommunityDocs/ Stephanie/Collegians/2010\%20Lampstand\%20Part\%202.pdf, (accessed 6 October 2011)

Stewart, Alison G., 'Beham', Grove Art Online. Oxford Art Online, VUW Lib, http://www.oxfordartonline.com/subscriber/article/grove/art/T007324pg2 (accessed November 16, 2011)

Strieder, Peter, 'Pleydenwurff', Grove Art Online. Oxford Art Online, VUW Lib. http://www.oxfordartonline.com/subscriber/article/grove/art/T068143pg2 (accessed November 16, 2011).

, 'Wolgemut, Michael', Grove Art Online. Oxford Art Online, VUW Lib. http://www.oxfordartonline.com/subscriber/article/grove/art/T092044, (accessed November 16, 2011).

Talbot, Charles W., 'Altdorfer', Grove Art Online. Oxford Art Online, VUW Lib. http://www.oxfordartonline.com/subscriber/article/grove/art/T002094pg1 (accessed November 16, 2011).

, ‘Cranach', Grove Art Online. Oxford Art Online, VUW Lib.

http://www.oxfordartonline.com/subscriber/article/grove/art/T020110pg1 (accessed November 16, 2011).

'The Harold Wright Scholarship and the Sarah and William Holmes Scholarship', http://www.printsandprintmaking.gov.au/Awards/TheHaroldWrightScholarship. aspx, (accessed 16 September 2011)

Tittler, Robert and Anne Thackray, 'Print collecting in provincial England prior to 1650: The Randle Holme Album’, The British Art Journal, 9 (2), 2008, pp. 3-10

Wegner, Wolfgang, 'Beiträge zum Graphischen Werk Daniel Hopfers', Zeitschrift für Kunstgeschichte, 20 (3), 1957, pp. 239-259, JSTOR, VUW Lib. http://www.jstor.org, (accessed 15 January 2012)

'Wellington', Otago Witness, Issue 754, 12 May 1866, p. 8, http://paperspast.natlib.govt.nz /cgi-bin/imageserver/imageserver.pl?oid=OW18660512.2.22\&area= 9\&width=436\&color=32\&ext=gif\&key=, (accessed 10 August 2011)

Williams, Hermann Warner, Jr., 'An unrecorded masterpiece by Hans Collaert the Elder', The Burlington Magazine for Connoisseurs, 70 (407), 1937, pp. 82-83+87, JSTOR, VUW Lib. http://www.jstor.org, (accessed 15 January 2012) 


\section{M.A. and Ph.D. Theses}

Cooper, Joanne Rachel, Old Master Print Collecting in New Zealand, M.A. diss., Auckland: University of Auckland, 2006

Gregory, Sharon Lynne, Vasari and Northern prints: An examination of Giorgio Vasari's comments on, and use of, woodcuts and engravings by Martin Schongauer, Albrecht Duerer and Lucas van Leyden, M.A. diss., Canada: Queen's University at Kingston,1992, Dissertations \& Theses: Full Text, VUW Lib. http://www.proquest.com.helicon.vuw.ac.nz, (accessed 9 June 2011)

Malpas, Julianne, An incurable collector: Sir John Ilott (1884-1973) and his passion for prints, M.A. diss., Wellington: Victoria University of Wellington, 2005

Michaux, Lisa Dickinson, A tale of two cities: The Ladd Collection in the context of early 20th century print patronage in Portland, Oregon and Minneapolis, Minnesota, Ph.D. diss., Minnesota: University of Minnesota, 2001, Dissertations \& Theses: Full Text, VUW Lib. http://www.proquest.com.helicon.vuw.ac.nz, (accessed 9 June 2011)

Norman, Mathew, The print collection of Bishop Monrad (1811-1887), M.A. diss., Wellington: Victoria University of Wellington, 2006

Reilly, Emma, Walter Auburn and his collection of prints, M.A. diss., Auckland: University of Auckland, 2003

Riggs, Timothy A., Hieronymus Cock: Printmaker and Publisher, Ph. D. diss., New York; London: Garland, 1977 


\section{Appendix}

\begin{tabular}{|c|c|c|c|c|c|c|}
\hline Artist & School & Title and Date & Medium & $\begin{array}{l}\text { Accession } \\
\text { Number }\end{array}$ & Source & Additional Notes \\
\hline Aldegrever, Heinrich & German & $\begin{array}{l}\text { The story of the first men. Plate } 6 . \\
\text { Adam and Eve at work, } 1540\end{array}$ & Engraving & 1869-0001-5 & Bishop Monrad & \\
\hline Aldegrever, Heinrich & German & The Annunciation, 1553 & Engraving & 1869-0001-6 & Bishop Monrad & \\
\hline $\begin{array}{l}\text { Aldegrever, Heinrich } \\
\text { (after Albrecht Dürer) }\end{array}$ & German & St. Christopher, 1527 (1521) & Engraving & 1869-0001-7 & Bishop Monrad & \\
\hline Aldegrever, Heinrich & German & $\begin{array}{l}\text { Sophonisbe drinks the poison cup, } \\
1553\end{array}$ & Engraving & 1869-0001-8 & Bishop Monrad & \\
\hline Aldegrever, Heinrich & German & $\begin{array}{l}\text { Ornament with foliage and a vase in } \\
\text { the centre, } 1528\end{array}$ & Engraving & 1869-0001-10 & Bishop Monrad & \\
\hline $\begin{array}{l}\text { Aldegrever, Heinrich (after } \\
\text { Lucas Cranach the Elder) }\end{array}$ & German & Philip Melanchthon, 1540 (1532) & Enrgaving & 1971-0048-1 & Sir John Ilott & Watermark of a bear, 1534 \\
\hline Aldegrever, Heinrich & German & The Virtues. Modesty, 1552 & Engraving & 1978-0006-4/ 1 & $\begin{array}{l}\text { Ellen Eames } \\
\text { Collection funds }\end{array}$ & \\
\hline Aldegrever, Heinrich & German & The Virtues. Compassion, 1552 & Engraving & $1978-0006-4 / 2$ & $\begin{array}{l}\text { Ellen Eames } \\
\text { Collection funds }\end{array}$ & \\
\hline Aldegrever, Heinrich & German & The Virtues. Temperance, 1552 & Engraving & 1978-0006-4/ 5 & $\begin{array}{l}\text { Ellen Eames } \\
\text { Collection funds }\end{array}$ & \\
\hline Aldegrever, Heinrich & German & The Virtues. Charity, 1552 & Engraving & 1978-0006-4/ 6 & $\begin{array}{l}\text { Ellen Eames } \\
\text { Collection funds }\end{array}$ & \\
\hline Aldegrever, Heinrich & German & The Virtues. Diligence, 1552 & Engraving & $1978-0006-4 / 7$ & $\begin{array}{l}\text { Ellen Eames } \\
\text { Collection funds }\end{array}$ & \\
\hline Aldegrever, Heinrich & German & The Vices. Pride, 1552 & Engraving & 1978-0006-5/ 1 & $\begin{array}{l}\text { Ellen Eames } \\
\text { Collection funds }\end{array}$ & \\
\hline Aldegrever, Heinrich & German & The Vices. Envy, 1552 & Engraving & 1978-0006-5/ 2 & $\begin{array}{l}\text { Ellen Eames } \\
\text { Collection funds }\end{array}$ & \\
\hline Aldegrever, Heinrich & German & The Vices. Wrath, 1552 & Engraving & $1978-0006-5 / 3$ & $\begin{array}{l}\text { Ellen Eames } \\
\text { Collection funds }\end{array}$ & \\
\hline Aldegrever, Heinrich & German & The Vices. Lust, 1552 & Engraving & 1978-0006-5/ 4 & $\begin{array}{l}\text { Ellen Eames } \\
\text { Collection funds }\end{array}$ & \\
\hline
\end{tabular}




\begin{tabular}{|c|c|c|c|c|c|}
\hline Artist & School & Title and Date & Medium & $\begin{array}{l}\text { Accession } \\
\text { Number }\end{array}$ & Additional Notes \\
\hline Aldegrever, Heinrich & German & The Vices. Gluttony, 1552 & Engraving & $1978-0006-5 / 5$ & $\begin{array}{l}\text { Ellen Eames } \\
\text { Collection funds }\end{array}$ \\
\hline Aldegrever, Heinrich & German & The Vices. Avarice, 1552 & Engraving & 1978-0006-5/ 6 & $\begin{array}{l}\text { Ellen Eames } \\
\text { Collection funds }\end{array}$ \\
\hline Aldegrever, Heinrich & German & The Vices. Idleness, 1552 & Engraving & $1978-0006-5 / 7$ & $\begin{array}{l}\text { Ellen Eames } \\
\text { Collection funds }\end{array}$ \\
\hline $\begin{array}{l}\text { Altdorfer, Albrecht (after } \\
\text { Marcantonio Raimondi) } \\
\text { (c. } 1480 \text { - 1538) }\end{array}$ & German & Venus after the bath, 1520-1526 & Engraving & 1869-0001-11 & Bishop Monrad \\
\hline Altdorfer, Albrecht & German & $\begin{array}{l}\text { Genius with a pair of bellows, } 1520- \\
1526\end{array}$ & Engraving & 1869-0001-12 & Bishop Monrad \\
\hline Altdorfer, Albrecht & German & $\begin{array}{l}\text { Knight with bread and wine } \\
\text { (Melchisedek), 1520-1526 }\end{array}$ & Engraving & $1869-0001-13$ & Bishop Monrad \\
\hline $\begin{array}{l}\text { Baldung, Hans (c. 1484- } \\
\text { 1545) }\end{array}$ & German & St. Barbara, 1505-1507 & Woodcut & 1869-0001-133 & Bishop Monrad \\
\hline Baldung, Hans & German & St. Catherine, 1505-1507 & Woodcut & 1869-0001-134 & Bishop Monrad \\
\hline Beham, Barthel (1502-1540) & German & $\begin{array}{l}\text { A genius on a globe flying above a } \\
\text { landscape, } 1520\end{array}$ & Engraving & 1965-0012-10 & Mrs Harold Wright \\
\hline $\begin{array}{l}\text { Beham, Hans Sebald (1500- } \\
\text { 1550) }\end{array}$ & German & Satyr playing lyre, 1531-1550 & Engraving & $1869-0001-27$ & Bishop Monrad \\
\hline Beham, Hans Sebald & German & $\begin{array}{l}\text { Satyr woman playing bagpipe, 1531- } \\
1550\end{array}$ & Engraving & 1869-0001-28 & Bishop Monrad \\
\hline Beham, Hans Sebald & German & Satyr sounding a horn, 1531-1550 & Engraving & 1869-0001-29 & Bishop Monrad \\
\hline Beham, Hans Sebald & German & $\begin{array}{l}\text { The weather peasant, "Es ist kalt } \\
\text { weter", } 1542\end{array}$ & Engraving & $1869-0001-30$ & Bishop Monrad \\
\hline Beham, Hans Sebald & German & $\begin{array}{l}\text { The weather peasant, "Das schadet } \\
\text { nit", } 1542\end{array}$ & Engraving & 1869-0001-31 & Bishop Monrad \\
\hline Beham, Hans Sebald & German & Capital and base of a column, 1543 & Engraving & 1970-0019-2 & $\begin{array}{l}\text { Sir John Ilott } \\
\text { (bought from C/B } \\
\text { for } £ 30 \text { ) }\end{array}$ \\
\hline Beham, Hans Sebald & German & A mask held by two genii, 1544 & Engraving & $1959-0023-3$ & $\begin{array}{l}\text { Sir John Ilott } \\
\text { (bought from } \\
\text { Colnaghi’s) }\end{array}$ \\
\hline $\begin{array}{l}\text { Unknown after Hans Sebald } \\
\text { Beham }\end{array}$ & & $\begin{array}{l}\text { Copy after Plate } 3 \text { from The } \\
\text { Peasants’ Festival and Twelve } \\
\text { Months, 1546-1600 (1546-1547) }\end{array}$ & Engraving & 1983-0067-2 & $\begin{array}{l}\text { New Zealand } \\
\text { Lottery Board funds }\end{array}$ \\
\hline $\begin{array}{l}\text { Unknown after Hans Sebald } \\
\text { Beham }\end{array}$ & & $\begin{array}{l}\text { Copy after Plate } 6 \text { from The } \\
\text { Peasants’ Festival and Twelve } \\
\text { Months, 1546-1600 (1546-1547) }\end{array}$ & Engraving & $1983-0067-3$ & $\begin{array}{l}\text { New Zealand } \\
\text { Lottery Board funds }\end{array}$ \\
\hline
\end{tabular}




\begin{tabular}{|c|c|c|c|c|c|c|}
\hline Artist & School & Title and Date & Medium & $\begin{array}{l}\text { Accession } \\
\text { Number }\end{array}$ & Source & Additional Notes \\
\hline $\begin{array}{l}\text { Binck, Jakob (after Barthel } \\
\text { Beham) (c. 1500-c. 1569) }\end{array}$ & German & Judith, 1528 & Engraving & 1869-0001-26 & Bishop Monrad & \\
\hline Bril, Paulus (1554-1626) & Flemish & $\begin{array}{l}\text { River landscape with a shepherd on a } \\
\text { hill to the right. From: Views of the } \\
\text { coast of Campania, }\end{array}$ & Etching & $1869-0001-50$ & Bishop Monrad & \\
\hline $\begin{array}{l}\text { Cock, Hieronymus (after } \\
\text { Matthijs Cock) } \\
\text { (c. } 1510-1570) \\
\end{array}$ & Flemish & $\begin{array}{l}\text { Landscapes with biblical and } \\
\text { mythological scenes. The good } \\
\text { Samaritan, } 1558\end{array}$ & Etching & 1869-0001-91 & Bishop Monrad & \\
\hline $\begin{array}{l}\text { Cock, Hieronymus (after } \\
\text { Matthijs Cock) }\end{array}$ & Flemish & $\begin{array}{l}\text { Landscapes with biblical and } \\
\text { mythological scenes. Tobit, } 1558\end{array}$ & Etching & 1869-0001-92 & Bishop Monrad & \\
\hline $\begin{array}{l}\text { Cock, Hieronymus (after } \\
\text { Matthijs Cock) }\end{array}$ & Flemish & $\begin{array}{l}\text { Mercury with the head of Argus in } \\
\text { his hand. From: Landscapes with } \\
\text { biblical and mythological scenes, } \\
1558\end{array}$ & Etching & 1869-0001-93 & Bishop Monrad & \\
\hline Collaert, Jan (1566 - 1628) & Flemish & Huntings & Engraving & $\begin{array}{l}1990-0035-1 / 1- \\
1990-003501 / 16\end{array}$ & Sir Arthur Ward & $\begin{array}{l}\text { collector's mark with a crown } \\
\text { and the initials B. L. on recto } \\
\text { (unidentified by Lugt) }\end{array}$ \\
\hline $\begin{array}{l}\text { Cort, Cornelis (after Titian } \\
\text { Vecelli) (c. } 1533 \text { - c. 1578) }\end{array}$ & Dutch & $\begin{array}{l}\text { St Jerome reading in the desert, } \\
\text { (1565) }\end{array}$ & Engraving & $1910-0001-71-80$ & George IV Album & \\
\hline $\begin{array}{l}\text { Cranach, Lucas, the Elder } \\
(1472-1553)\end{array}$ & German & $\begin{array}{l}\text { The penance of St. John Chrysostom, } \\
1509\end{array}$ & Engraving & 1869-0001-98 & Bishop Monrad & \\
\hline $\begin{array}{l}\text { Dürer, Albrecht (1471 - } \\
\text { 1528) }\end{array}$ & German & $\begin{array}{l}\text { The Passion. The harrowing of Hell, } \\
1512\end{array}$ & Engraving & 1869-0001-116 & Bishop Monrad & \\
\hline $\begin{array}{l}\text { Unknown after Albrecht } \\
\text { Dürer }\end{array}$ & & $\begin{array}{l}\text { Reverse copy of The harrowing of } \\
\text { Hell, (1512) }\end{array}$ & Engraving & $1869-0001-117$ & Bishop Monrad & \\
\hline Dürer, Albrecht & German & The Virgin nursing the child, 1519 & Engraving & 1869-0001-118 & Bishop Monrad & \\
\hline Dürer, Albrecht & German & $\begin{array}{l}\text { The Virgin on the crescent with a } \\
\text { sceptre and a starry crown, } 1516\end{array}$ & Engraving & 1869-0001-119 & Bishop Monrad & \\
\hline Dürer, Albrecht & German & $\begin{array}{l}\text { The Virgin and child crowned by two } \\
\text { angels, } 1518\end{array}$ & Engraving & $1869-0001-120$ & Bishop Monrad & \\
\hline Dürer, Albrecht & German & $\begin{array}{l}\text { The Virgin and child seated by the } \\
\text { wall, } 1514\end{array}$ & Engraving & 1869-0001-121 & Bishop Monrad & \\
\hline Dürer, Albrecht & German & St. George on horseback, 1508 & Engraving & 1869-0001-122 & Bishop Monrad & \\
\hline Dürer, Albrecht & German & St. Eustace, c. 1501 & Engraving & 1869-0001-123 & Bishop Monrad & \\
\hline Dürer, Albrecht & German & Melencolia I, 1514 & Engraving & $1869-0001-124$ & Bishop Monrad & \\
\hline Dürer, Albrecht & German & The peasant couple at market, 1519 & Engraving & 1869-0001-125 & Bishop Monrad & \\
\hline Dürer, Albrecht & German & The large horse, 1505 & Engraving & $1869-0001-126$ & Bishop Monrad & $\begin{array}{l}\text { Pencil drawing of a horse's head } \\
\text { on the verso }\end{array}$ \\
\hline
\end{tabular}




\begin{tabular}{|c|c|c|c|c|c|c|}
\hline Artist & School & Title and Date & Medium & $\begin{array}{l}\text { Accession } \\
\text { Number }\end{array}$ & Source & Additional Notes \\
\hline Dürer, Albrecht & German & $\begin{array}{l}\text { Cardinal Albrecht of Brandenburg } \\
\text { (The large cardinal), } 1523\end{array}$ & Engraving & 1869-0001-127 & Bishop Monrad & \\
\hline Dürer, Albrecht & German & Philipp Melanchthon, 1526 & Engraving & 1869-0001-128 & Bishop Monrad & \\
\hline Dürer, Albrecht & German & The witch, 1501-1502 & Engraving & $1869-0001-129$ & Bishop Monrad & \\
\hline Dürer, Albrecht & German & $\begin{array}{l}\text { Samson fighting with the lion, 1496- } \\
1497\end{array}$ & Woodcut & 1869-0001-130 & Bishop Monrad & \\
\hline Dürer, Albrecht & German & $\begin{array}{l}\text { Christ on the Mount of Olives. From: } \\
\text { The Large Passion, } 1497\end{array}$ & Woodcut & 1869-0001-131 & Bishop Monrad & \\
\hline Dürer, Albrecht & German & $\begin{array}{l}\text { The large Passion. Christ in Limbo, } \\
1510\end{array}$ & Woodcut & 1869-0001-132 & Bishop Monrad & \\
\hline Dürer, Albrecht & German & $\begin{array}{l}\text { Martyrdom of St. Catherine. From: } \\
\text { Albertina Passion, 1497-1498 }\end{array}$ & Woodcut & $1910-0001-1.1-80$ & George IV Album & \\
\hline Dürer, Albrecht & German & $\begin{array}{l}\text { The Passion. Christ on the cross, } \\
1511\end{array}$ & Engraving & 1952-0003-148 & $\begin{array}{l}\text { Sir John Ilott (gift } \\
\text { from Colnaghi’s) }\end{array}$ & $\begin{array}{l}\text { Collector's mark of Frederick } \\
\text { Koch (1770-1832) on verso }\end{array}$ \\
\hline Dürer, Albrecht & German & $\begin{array}{l}\text { The Virgin and Child on the crescent } \\
\text { with a diadem, } 1514\end{array}$ & Engraving & 1952-0003-149 & $\begin{array}{l}\text { Sir John Ilott } \\
\text { (bought from } \\
\text { Holderns for } £ 7.1 \mathrm{~s} \text { ) } \\
\end{array}$ & \\
\hline Dürer, Albrecht & German & Nemesis (the Great Fortune), c. 1502 & Engraving & $1952-0003-150$ & $\begin{array}{l}\text { Sir John Ilott } \\
\text { (bought from } \\
\text { Colnaghi's for £60) }\end{array}$ & \\
\hline Dürer, Albrecht & German & Five Apostles. Bartholomew, 1523 & Engraving & 1952-0003-151 & $\begin{array}{l}\text { Sir John Ilott } \\
\text { (bought from } \\
\text { Colnaghi’s for £12) }\end{array}$ & $\begin{array}{l}\text { Collector's mark of Paul } \\
\text { Behaim (1592-1637) on verso; } \\
\text { Inscribed 'T.D.Barlow’ on verso }\end{array}$ \\
\hline Dürer, Albrecht & German & Hercules, c. 1498 & Engraving & $1956-0001-9$ & $\begin{array}{l}\text { Sir John Ilott } \\
\text { (bought from } \\
\text { Colnaghi’s for £80) }\end{array}$ & \\
\hline Dürer, Albrecht & German & The prodigal son, c. 1496 & Engraving & 1958-0003-1 & $\begin{array}{l}\text { Sir John Ilott } \\
\text { (bought from } \\
\text { Colnaghi’s for } £ 50 \text { ) }\end{array}$ & \\
\hline Dürer, Albrecht & German & Melencolia I, 1514 & Engraving & 1959-0023-1 & $\begin{array}{l}\text { Sir John Ilott } \\
\text { (Colnaghi‘s) }\end{array}$ & \\
\hline Dürer, Albrecht & German & Five Apostles. Simon, 1523 & Engraving & $1959-0023-2$ & $\begin{array}{l}\text { Sir John Ilott } \\
\text { (Colnaghi's) }\end{array}$ & $\begin{array}{l}\text { Collector’s mark of David } \\
\text { Bernhard Hausmann (1784- } \\
\text { 1874) on verso; Collector’s } \\
\text { mark of P. von Baldinger- } \\
\text { Seidenberg († 1911) on verso }\end{array}$ \\
\hline Dürer, Albrecht & German & $\begin{array}{l}\text { Crucifixion. From : The Large } \\
\text { Passion, 1497-1498 }\end{array}$ & Woodcut & $1960-0009-2$ & Mrs Hilda Webb & \\
\hline
\end{tabular}




\begin{tabular}{|c|c|c|c|c|c|c|}
\hline Artist & School & Title and Date & Medium & $\begin{array}{l}\text { Accession } \\
\text { Number }\end{array}$ & Source & Additional Notes \\
\hline Dürer, Albrecht & German & The large horse, 1505 & Engraving & $1962-0001-9$ & $\begin{array}{l}\text { Sir John Ilott } \\
\text { (bought from } \\
\text { Colnaghi's for } \\
£ 120 \text { ) }\end{array}$ & \\
\hline Dürer, Albrecht & German & The Holy Trinity, 1511 & Woodcut & $1963-0005-5$ & $\begin{array}{l}\text { Sir John Ilott } \\
\text { (bought from } \\
\text { Colnaghi’s for } \\
£ 115 \text { ) }\end{array}$ & \\
\hline Dürer, Albrecht & German & $\begin{array}{l}\text { The little Passion. Christ in Emmaus, } \\
1511\end{array}$ & Woodcut & 1964-0001-1 & $\begin{array}{l}\text { Sir John Ilott } \\
\text { (bought from } \\
\text { Colnaghi’s for £77) }\end{array}$ & \\
\hline Dürer, Albrecht & German & St Jerome in his cell, 1511 & Woodcut & 1964-0001-2 & $\begin{array}{l}\text { Sir John Ilott } \\
\text { (bought from } \\
\text { Colnaghi’s for } \\
£ 110 \text { ) }\end{array}$ & $\begin{array}{l}\text { Collector's mark of Siegfried } \\
\text { Barden (1854-1917) on verso }\end{array}$ \\
\hline Dürer, Albrecht & German & $\begin{array}{l}\text { The life of the Virgin. The Adoration } \\
\text { of the Magi, c. 1501-1503 }\end{array}$ & Woodcut & $1965-0012-48$ & Mrs Harold Wright & $\begin{array}{l}\text { Watermark of a spread eagle } \\
\text { surmounted by crown, inscribed } \\
\text { DLordon on verso (possibly an } \\
\text { owner's mark), pencil drawing } \\
\text { of seated man on verso }\end{array}$ \\
\hline Dürer, Albrecht & German & $\begin{array}{l}\text { The large Passion. Christ in Limbo, } \\
1510\end{array}$ & Woodcut & $1966-0005-2$ & $\begin{array}{l}\text { Sir John Ilott } \\
\text { (bought from } \\
\text { Colnaghi’s for £70) }\end{array}$ & \\
\hline Dürer, Albrecht & German & $\begin{array}{l}\text { The life of the Virgin. Joachim's } \\
\text { offering rejected, c. } 1504\end{array}$ & Woodcut & $1966-0005-3$ & $\begin{array}{l}\text { Sir John Ilott } \\
\text { (bought from } \\
\text { Colnaghi’s for £40) } \\
\end{array}$ & \\
\hline Dürer, Albrecht & German & $\begin{array}{l}\text { The Sudarium held by one angel, } \\
1516\end{array}$ & Etching & $1967-0027-6$ & $\begin{array}{l}\text { Dr and Mrs John } \\
\text { Hardwick-Smith }\end{array}$ & \\
\hline Dürer, Albrecht & German & $\begin{array}{l}\text { The little Passion. Christ before } \\
\text { Annas, c. 1508-1509 }\end{array}$ & Woodcut & 1968-0001-21 & Sir John Ilott & $\begin{array}{l}\text { Chalk [?] design for foliage } \\
\text { ornamentation on verso }\end{array}$ \\
\hline Dürer, Albrecht & German & $\begin{array}{l}\text { The martyrdom of the ten thousand. } \\
\text { From: Albertina Passion, 1497-1498 }\end{array}$ & Woodcut & 1971-0028-1 & $\begin{array}{l}\text { Harold Beauchamp } \\
\text { Collection funds }\end{array}$ & \\
\hline Dürer, Albrecht & German & $\begin{array}{l}\text { The Four Horsemen. From : } \\
\text { Apocalypse, } 1498\end{array}$ & Woodcut & 1971-0028-2 & $\begin{array}{l}\text { Harold Beauchamp } \\
\text { Collection funds }\end{array}$ & $\begin{array}{l}\text { Collector's mark of Siegfried } \\
\text { Barden (1854-1917) on verso }\end{array}$ \\
\hline Dürer, Albrecht & German & $\begin{array}{l}\text { Assumption and coronation of the } \\
\text { Virgin. From : Life of the Virgin, } \\
1510\end{array}$ & Woodcut & 1971-0028-4 & $\begin{array}{l}\text { Harold Beauchamp } \\
\text { Collection funds }\end{array}$ & \\
\hline Dürer, Albrecht & German & $\begin{array}{l}\text { Frederick the wise, Elector of } \\
\text { Saxony, } 1524\end{array}$ & Engraving & 1971-0039-1 & $\begin{array}{l}\text { Harold Beauchamp } \\
\text { Collection funds }\end{array}$ & \\
\hline
\end{tabular}




\begin{tabular}{|c|c|c|c|c|c|c|}
\hline Artist & School & Title and Date & Medium & $\begin{array}{l}\text { Accession } \\
\text { Number }\end{array}$ & Source & Additional Notes \\
\hline Dürer, Albrecht & German & $\begin{array}{l}\text { Agony in the garden. From: The } \\
\text { small passion, 1509-1511 }\end{array}$ & Woodcut & $1973-0027-1$ & $\begin{array}{l}\text { Mary Buick } \\
\text { Bequest funds }\end{array}$ & \\
\hline Dürer, Albrecht & German & $\begin{array}{l}\text { The beast with two horns like a lamb. } \\
\text { From: Apocalypse series (15 blocks), } \\
\text { 1497-1498 }\end{array}$ & Woodcut & 1976-0005-1 & $\begin{array}{l}\text { Ellen Eames } \\
\text { Collection funds }\end{array}$ & $\begin{array}{l}\text { Watermark with Reichsapfel of } \\
\text { imperial orb }\end{array}$ \\
\hline Galle, Philipp (1537 - 1612) & Flemish & Christ crucified between two thieves & $\begin{array}{l}\text { Etching, } \\
\text { Engraving }\end{array}$ & $1970-0030-7$ & Sir John Ilott & \\
\hline $\begin{array}{l}\text { Galle, Philipp (after Marten } \\
\text { van Heemskerck) }\end{array}$ & Flemish & $\begin{array}{l}\text { The Apostles baptising at the Feast of } \\
\text { Pentecost }\end{array}$ & Engraving & $1970-0030-8$ & Sir John Ilott & \\
\hline $\begin{array}{l}\text { Galle, Philipp (after Marten } \\
\text { van Heemskerck) }\end{array}$ & Flemish & $\begin{array}{l}\text { SS. Peter and John blessing the } \\
\text { people of Samaria }\end{array}$ & Engraving & $1970-0030-9$ & Sir John Ilott & \\
\hline $\begin{array}{l}\text { Goltzius, Hendrick (after } \\
\text { Jacopo Palma) } \\
(1558-1617) \\
\end{array}$ & Dutch & St. Jerome in the desert, 1596 & Engraving & 1869-0001-157 & Bishop Monrad & \\
\hline Goltzius, Hendrick & Dutch & $\begin{array}{l}\text { The Last Supper. Plate 1. From: The } \\
\text { Passion, } 1598\end{array}$ & Engraving & 1983-0004-1 & $\begin{array}{l}\text { Ellen Eames } \\
\text { Collection funds }\end{array}$ & \\
\hline Goltzius, Hendrick & Dutch & $\begin{array}{l}\text { Christ on the Mount of Olives. Plate } \\
\text { 2. From: The Passion, } 1597\end{array}$ & Engraving & $1983-0004-2$ & $\begin{array}{l}\text { Ellen Eames } \\
\text { Collection funds }\end{array}$ & \\
\hline Goltzius, Hendrick & Dutch & $\begin{array}{l}\text { Christ taken captive. Plate 3. From: } \\
\text { The Passion, } 1598\end{array}$ & Engraving & $1983-0004-3$ & $\begin{array}{l}\text { Ellen Eames } \\
\text { Collection funds }\end{array}$ & \\
\hline Goltzius, Hendrick & Dutch & $\begin{array}{l}\text { Christ before Caiaphas. Plate } 4 . \\
\text { From: The Passion, } 1597\end{array}$ & Engraving & $1983-0004-4$ & $\begin{array}{l}\text { Ellen Eames } \\
\text { Collection funds }\end{array}$ & \\
\hline Goltzius, Hendrick & Dutch & $\begin{array}{l}\text { Christ before Pilate. Plate 5. From: } \\
\text { The Passion, } 1596\end{array}$ & Engraving & $1983-0004-5$ & $\begin{array}{l}\text { Ellen Eames } \\
\text { Collection funds }\end{array}$ & \\
\hline Goltzius, Hendrick & Dutch & $\begin{array}{l}\text { Flagellation of Christ. Plate 6. From: } \\
\text { The Passion, } 1597\end{array}$ & Engraving & 1983-0004-6 & $\begin{array}{l}\text { Ellen Eames } \\
\text { Collection funds }\end{array}$ & \\
\hline Goltzius, Hendrick & Dutch & $\begin{array}{l}\text { Ecce Homo. Plate 8. From: The } \\
\text { Passion, } 1597\end{array}$ & Engraving & 1983-0004-7 & $\begin{array}{l}\text { Ellen Eames } \\
\text { Collection funds }\end{array}$ & \\
\hline Goltzius, Hendrick & Dutch & $\begin{array}{l}\text { Christ carrying the Cross. Plate } 9 . \\
\text { From: The Passion, 1596-1598 }\end{array}$ & Engraving & 1983-0004-8 & $\begin{array}{l}\text { Ellen Eames } \\
\text { Collection funds }\end{array}$ & \\
\hline Goltzius, Hendrick & Dutch & $\begin{array}{l}\text { Burial of Christ. Plate 11. From: The } \\
\text { Passion, } 1596\end{array}$ & Engraving & 1983-0004-9 & $\begin{array}{l}\text { Ellen Eames } \\
\text { Collection funds }\end{array}$ & \\
\hline $\begin{array}{l}\text { Hopfer, Daniel } \\
\text { (c. } 1470-1536)\end{array}$ & German & $\begin{array}{l}\text { Geometric design for an ornamented } \\
\text { ceiling (published early } 17^{\text {th }} \text { century } \\
\text { by David Funck) }\end{array}$ & Etching & $2009-0003-3$ & & \\
\hline $\begin{array}{l}\text { Huberti, Adrian (after Martin } \\
\text { Schongauer) }\end{array}$ & Flemish & $\begin{array}{l}\text { Agony in the Garden, } 1584 \text { (1470- } \\
1480)\end{array}$ & Engraving & 1965-0016-2 & F.W. Littlejohn & \\
\hline $\begin{array}{l}\text { Leyden, Lucas van (1494 - } \\
\text { 1533) }\end{array}$ & Dutch & The fall of man, 1529 & Engraving & 1869-0001-288 & Bishop Monrad & \\
\hline
\end{tabular}




\begin{tabular}{|c|c|c|c|c|c|}
\hline Artist & School & Title and Date & Medium & $\begin{array}{l}\text { Accession } \\
\text { Number }\end{array}$ & Additional Notes \\
\hline Leyden, Lucas van & Dutch & Cain killing Abel, 1524 & Engraving & 1869-0001-289 & Bishop Monrad \\
\hline Leyden, Lucas van & Dutch & David praying, 1508 & Engraving & 1869-0001-290 & Bishop Monrad \\
\hline Leyden, Lucas van & Dutch & Christ and the Apostles. Christ, 1510 & Engraving & 1869-0001-291 & Bishop Monrad \\
\hline Leyden, Lucas van & Dutch & Christ and the Apostles. Peter, 1510 & Engraving & 1869-0001-292 & Bishop Monrad \\
\hline Leyden, Lucas van & Dutch & Christ and the Apostles. Paul, 1510 & Engraving & 1869-0001-293 & Bishop Monrad \\
\hline Leyden, Lucas van & Dutch & $\begin{array}{l}\text { Christ and the Apostles. Andrew, } \\
1510\end{array}$ & Engraving & 1869-0001-294 & Bishop Monrad \\
\hline Leyden, Lucas van & Dutch & Christ and the Apostles. John, 1510 & Engraving & 1869-0001-295 & Bishop Monrad \\
\hline Leyden, Lucas van & Dutch & $\begin{array}{l}\text { Christ and the Apostles. Jack the } \\
\text { Elder, } 1510\end{array}$ & Engraving & 1869-0001-296 & Bishop Monrad \\
\hline Leyden, Lucas van & Dutch & $\begin{array}{l}\text { Christ and the Apostles. Thomas, } \\
1510\end{array}$ & Engraving & 1869-0001-297 & Bishop Monrad \\
\hline Leyden, Lucas van & Dutch & $\begin{array}{l}\text { Christ and the Apostles. Judas } \\
\text { Thaddaeus, } 1510\end{array}$ & Engraving & 1869-0001-298 & Bishop Monrad \\
\hline Leyden, Lucas van & Dutch & $\begin{array}{l}\text { Christ and the Apostles. } \\
\text { Bartholomew, } 1510\end{array}$ & Engraving & 1869-0001-299 & Bishop Monrad \\
\hline Leyden, Lucas van & Dutch & Christ and the Apostles. Philip, 1510 & Engraving & 1869-0001-300 & Bishop Monrad \\
\hline Leyden, Lucas van & Dutch & $\begin{array}{l}\text { Christ and the Apostles. Jack the } \\
\text { Younger, } 1510\end{array}$ & Engraving & 1869-0001-301 & Bishop Monrad \\
\hline Leyden, Lucas van & Dutch & Christ and the Apostles. Simon, 1510 & Engraving & 1869-0001-302 & Bishop Monrad \\
\hline Leyden, Lucas van & Dutch & $\begin{array}{l}\text { Christ and the Apostles. Matthew, } \\
1510\end{array}$ & Engraving & $1869-0001-303$ & Bishop Monrad \\
\hline Leyden, Lucas van & Dutch & $\begin{array}{l}\text { SS. Paul and Peter with the Vernicle, } \\
1517\end{array}$ & Engraving & 1869-0001-304 & Bishop Monrad \\
\hline Leyden, Lucas van & Dutch & The dentist, 1523 & Engraving & 1869-0001-305 & Bishop Monrad \\
\hline $\begin{array}{l}\text { Passe, Crispijn de, the Elder } \\
\text { (after Johann Rottenhammer) } \\
\text { (c.1564-1637) }\end{array}$ & Dutch & $\begin{array}{l}\text { Christ and the woman of Samaria, c. } \\
1600\end{array}$ & Engraving & $\begin{array}{l}1910-0001-1.60- \\
80\end{array}$ & George IV Album \\
\hline $\begin{array}{l}\text { Pencz, Georg (c. } 1500- \\
1550)\end{array}$ & German & $\begin{array}{l}\text { The story of Joseph. Joseph sold to } \\
\text { the Ishmaelites, } 1546\end{array}$ & Engraving & 1869-0001-381 & Bishop Monrad \\
\hline Pencz, Georg & German & Christ on the cross, 1547 & Engraving & 1869-0001-382 & Bishop Monrad \\
\hline $\begin{array}{l}\text { Pleydenwurff, Wilhelm } \\
\text { (author Schedel Hartmann) } \\
\text { (c. 1460-1494) }\end{array}$ & German & $\begin{array}{l}\text { Sexta etas mundi. From Liber } \\
\text { Chronicarum (The Nuremberg } \\
\text { Chronicle) fol.CI, (published } 1493 \text { by } \\
\text { Anton Koberger) }\end{array}$ & Woodcut & 2009-0011-2 & $\begin{array}{l}\text { Dunbar Sloane Ltd } \\
\text { (Wellington) }\end{array}$ \\
\hline $\begin{array}{l}\text { Sadeler, Aegidius (attributed) } \\
\text { (c. } 1570 \text { - 1629) }\end{array}$ & Flemish & $\begin{array}{l}\text { Riverscape with man being attacked } \\
\text { by three men }\end{array}$ & Engraving & $\begin{array}{l}1910-0001-1.37- \\
80\end{array}$ & George IV Album \\
\hline $\begin{array}{l}\text { Sadeler, Aegidius (artist } \\
\text { Roelandt Savery) }\end{array}$ & Flemish & $\begin{array}{l}\text { Wooded landscape with figures and } \\
\text { goats. Plate } 1 \text {. From a set of six }\end{array}$ & Engraving & $\begin{array}{l}1910-0001-1.38- \\
80\end{array}$ & George IV Album \\
\hline
\end{tabular}




\begin{tabular}{|c|c|c|c|c|c|c|}
\hline Artist & School & Title and Date & Medium & $\begin{array}{l}\text { Accession } \\
\text { Number }\end{array}$ & Source & Additional Notes \\
\hline & & landscapes & & & & \\
\hline $\begin{array}{l}\text { Sadeler, Aegidius (artist Jan } \\
\text { Brueghel) }\end{array}$ & Flemish & $\begin{array}{l}\text { Rocky landscape with the } \\
\text { stigmatisation of St Francis }\end{array}$ & Engraving & $\begin{array}{l}1910-0001-1.39- \\
80\end{array}$ & George IV Album & \\
\hline $\begin{array}{l}\text { Sadeler, Aegidius (artist } \\
\text { Paulus Bril) }\end{array}$ & Flemish & Mountainous landscape with a hermit & Engraving & $\begin{array}{l}1910-0001-1.40- \\
80\end{array}$ & George IV Album & \\
\hline $\begin{array}{l}\text { Saenredam, Jan (after } \\
\text { Hendrick Goltzius) }\end{array}$ & Dutch & $\begin{array}{l}\text { An allegory of visual perception } \\
\text { (published } 1616 \text { by Robert de } \\
\text { Boudous) }\end{array}$ & Engraving & 2011-0001-1 & $\begin{array}{l}\text { Christopher } \\
\text { Mendez (London) }\end{array}$ & \\
\hline $\begin{array}{l}\text { Schongauer, Martin (c. } 1448 \text { - } \\
\text { 1491) }\end{array}$ & German & $\begin{array}{l}\text { The Resurrection of Christ, 1470- } \\
1482\end{array}$ & Engraving & $1958-0003-6$ & Sir John Ilott & $\begin{array}{l}\text { Gothic P Watermark; Collection } \\
\text { Coppenrath, 1890, and } \\
\text { Collector's mark of Siegfried } \\
\text { Barden (1854-1917) on verso }\end{array}$ \\
\hline $\begin{array}{l}\text { Suavius, Lambert (c. } 1510 \text { - } \\
\text { 1567) }\end{array}$ & Dutch & $\begin{array}{l}\text { St James Minor. Plate 1. From: Christ } \\
\text { and the Apostles, } 1545\end{array}$ & Engraving & $1971-0048-8$ & Sir John Ilott & \\
\hline Suavius, Lambert & Dutch & $\begin{array}{l}\text { St Matthias. From: Christ and the } \\
\text { Apostles, c. } 1545\end{array}$ & Engraving & 1971-0048-9 & Sir John Ilott & \\
\hline Suavius, Lambert & Dutch & $\begin{array}{l}\text { St Andrew. Plate 3. From: Christ and } \\
\text { the Apostles, c. } 1545\end{array}$ & Engraving & $1971-0048-10$ & Sir John Ilott & \\
\hline Suavius, Lambert & Dutch & $\begin{array}{l}\text { St Simon. Plate 4. From: Christ and } \\
\text { the Apostles, } 1545\end{array}$ & Engraving & 1971-0048-11 & Sir John Ilott & \\
\hline Suavius, Lambert & Dutch & $\begin{array}{l}\text { St Bartholomew. Plate 5. From: } \\
\text { Christ and the Apostles, c. } 1545\end{array}$ & Engraving & $1971-0048-12$ & Sir John Ilott & \\
\hline Suavius, Lambert & Dutch & $\begin{array}{l}\text { St Philip. Plate 8. From: Christ and } \\
\text { the Apostles, c. } 1545\end{array}$ & Engraving & 1971-0048-13 & Sir John Ilott & \\
\hline Suavius, Lambert & Dutch & $\begin{array}{l}\text { St Matthew. Plate 7. From: Christ } \\
\text { and the Apostles, } 1547\end{array}$ & Engraving & 1971-0048-14 & Sir John Ilott & \\
\hline Suavius, Lambert & Dutch & $\begin{array}{l}\text { St Judas Thaddaeus. Plate 2. From: } \\
\text { Christ and the Apostles, } 1545\end{array}$ & Engraving & 1971-0048-15 & Sir John Ilott & \\
\hline Suavius, Lambert & Dutch & $\begin{array}{l}\text { St John the Evangelist. Plate 9. From: } \\
\text { Christ and the Apostles, } 1545\end{array}$ & Engraving & 1971-0048-16 & Sir John Ilott & \\
\hline Suavius, Lambert & Dutch & $\begin{array}{l}\text { St James Major. Plate 6. From: Christ } \\
\text { and the Apostles, } 1545\end{array}$ & Engraving & 1971-0048-17 & Sir John Ilott & \\
\hline Suavius, Lambert & Dutch & $\begin{array}{l}\text { St Peter. Plate 11. From: Christ and } \\
\text { the Apostles, } 1545\end{array}$ & Engraving & 1971-0048-18 & Sir John Ilott & \\
\hline Suavius, Lambert & Dutch & $\begin{array}{l}\text { St Paul. Plate 10. From: Christ and } \\
\text { the Apostles, } 1545\end{array}$ & Engraving & 1971-0048-19 & Sir John Ilott & \\
\hline Suavius, Lambert & Dutch & $\begin{array}{l}\text { Jesus Christ. Plate 12. From: Christ } \\
\text { and the Apostles, } 1548\end{array}$ & Engraving & 1971-0048-20 & Sir John Ilott & \\
\hline
\end{tabular}




\begin{tabular}{|c|c|c|c|c|c|}
\hline Artist & School & Title and Date & Medium & $\begin{array}{l}\text { Accession } \\
\text { Number }\end{array}$ & Additional Notes \\
\hline $\begin{array}{l}\text { Unknown (author Schedel } \\
\text { Hartmann) }\end{array}$ & & $\begin{array}{l}\text { Sexta etas mundi. From Liber } \\
\text { Chronicarum [The Nuremberg } \\
\text { Chronicle] fol. CCLVI, (published } \\
1493 \text { by Anton Koberger) }\end{array}$ & Woodcut & $2009-0011-3$ & $\begin{array}{l}\text { Dunbar Sloane Ltd } \\
\text { (Wellington) }\end{array}$ \\
\hline $\begin{array}{l}\text { Unknown (author Sebastian } \\
\text { Brant) }\end{array}$ & & $\begin{array}{l}\text { One page from Stultifera Navis [The } \\
\text { Ship of Fools], } 1497\end{array}$ & Woodcut & 2009-0011-4 & $\begin{array}{l}\text { Dunbar Sloane Ltd } \\
\text { (Wellington) }\end{array}$ \\
\hline $\begin{array}{l}\text { Unknown (author Sebastian } \\
\text { Brant) }\end{array}$ & & $\begin{array}{l}\text { Three pages from Stultifera Navis } \\
\text { [The Ship of Fools], } 1497\end{array}$ & Woodcut & $2009-0011-5$ & $\begin{array}{l}\text { Dunbar Sloane Ltd } \\
\text { (Wellington) }\end{array}$ \\
\hline $\begin{array}{l}\text { Wolgemut, Michael (author } \\
\text { Stephan Fridolin) } \\
\text { (1434-1519) }\end{array}$ & German & $\begin{array}{l}\text { The betrayal of Christ. From Der } \\
\text { schatzbehalter oder schrein der } \\
\text { wahren reichthumer des heils und der } \\
\text { ewigen seligkeit (Treasure container } \\
\text { or shrines of true riches of salvation } \\
\text { and everlasting blessedness), } 1491\end{array}$ & Woodcut & 1971-0028-3 & $\begin{array}{l}\text { Harold Beauchamp } \\
\text { Collection funds }\end{array}$ \\
\hline $\begin{array}{l}\text { Wolgemut, Michael (author } \\
\text { Schedel Hartmann) }\end{array}$ & German & $\begin{array}{l}\text { Secunda etas mundi. From Liber } \\
\text { Chronicarum (The Nuremberg } \\
\text { Chronicle] fol.XX, 1493(published } \\
1493 \text { by Anton Koberger) }\end{array}$ & Woodcut & 2009-0011-1.a & $\begin{array}{l}\text { Dunbar Sloane Ltd } \\
\text { (Wellington) }\end{array}$ \\
\hline $\begin{array}{l}\text { Wolgemut, Michael (author } \\
\text { Schedel Hartmann) }\end{array}$ & German & $\begin{array}{l}\text { Nineveh. From Liber Chronicarum } \\
\text { [The Nuremberg Chronicle] fol.XX, } \\
1493 \text { (published } 1493 \text { by Anton } \\
\text { Koberger) }\end{array}$ & Woodcut & 2009-0011-1.b & $\begin{array}{l}\text { Dunbar Sloane Ltd } \\
\text { (Wellington) }\end{array}$ \\
\hline
\end{tabular}

